\author{
UNIVERSIDADE DE SÃO PAULO \\ INSTITUTO DE FÍSICA DE SÃO CARLOS
}

SHEILA GONÇALVES DO COUTO CARVALHO

\title{
ESTUDOS ESTRUTURAIS E FUNCIONAIS DE DIIDROOROTATO DESIDROGENASES
}


SHEILA GONÇALVES DO COUTO CARVALHO

\section{ESTUDOS ESTRUTURAIS E FUNCIONAIS DE DIIDROOROTATO DESIDROGENASES}

Tese apresentada ao Instituto de Física de São Carlos, da Universidade de São Paulo, para obtenção do título de Doutor em Ciências.

Área de concentração: Física Aplicada.

Orientador: Prof. Dr. Antonio José da Costa Filho Co-orientadora: Profa. Dra. Maria Cristina Nonato

São Carlos 
AUTORIZO A REPRODUÇÃO E DIVULGAÇÃO TOTAL OU PARCIAL DESTE TRABALHO, POR QUALQUER MEIO CONVENCIONAL OU ELETRÔNICO, PARA FINS DE ESTUDO E PESQUISA, DESDE QUE CITADA A FONTE.

Ficha Catalográfica Elaborada pelo Serviço de Biblioteca e Informação - IFSC/USP

Carvalho, Sheila Gonçalves Couto.

Estudos estruturais e funcionais de diidroorotato

Desidrogenases / Shelia Gonçalves Couto Carvalho; orientador Antonio José da Costa Filho; co-orientadora Maria Cristina Nonato. - São Carlos, 2008. $174 \mathrm{f}$.

Tese (Doutorado - Programa de Pós-Graduação em Ciências. Area de

concentração: Física Aplicada ) - Instituto de Física de São Carlos da Universidade de São Paulo. 


\section{FOLHA DE APROVAÇÃO}

Sheila Gonçalves do Couto Carvalho

Tese apresentada ao Instituto de Física de São

Carlos da Universidade de São Paulo para obtenção do titulo de Doutor em Ciências. Área de Concentração: Física Aplicada.

Aprovada em: 28/03/2008

\section{Comissão Julgadora}

Prof. Dr. Antonio José da Costa Filho

Instituição: IFSC/USP

Assinatura



Prof. Dr. João Ruggiero Neto Instituição: IBILCE/UNESP



Prof. Dr. Ladislau Martin Neto Instituição: EMBRAPA Assinatura_tsin.

Prof. Dr. Pietro Ciancaglini Instituição: FFCLRP USP



Profa. Dra. Ana Paula Ulian de Araujo 
Ao meu amado Julio Cesar com amor e gratidão por sua compreensão, presença, amor incondicional, apoio e companheirismo ao longo do desenvolvimento deste trabalho;

Ao Dr. José Beniz Neto pela competência com a qual cuida de mim a 20 anos. Não fosse por essa competência eu não poderia ter chegado tão longe. 
"Que cada um considere a si mesmo, não como um homem procurando satisfazer sua própria sede de conhecimento,... mas como um colaborador numa grande obra comum relacionada com os interesses supremos da humanidade"

Hermann Von Helmholtz 


\section{Agradecimentos}

Agradeço,

Primeiramente a Deus por me fazer capaz de realizar este trabalho, dando-me saúde e discernimento;

Ao Prof. Dr. Antonio José da Costa Filho, não só pela sua dedicada orientação e amizade, mas principalmente por acreditar em mim;

À Profa. Dra. Maria Cristina Nonato (FCFRP/USP) pela co-orientação, amizade e noites de sono perdidas na tentativa de solucionar problemas relacionados a este trabalho;

Aos meus pais, Maria Cândida e José Orlando, pelo apoio e carinho durante o período em que estive me dedicando a este trabalho. Muito obrigada pela educação que me deram e por terem feito de mim a pessoa que hoje sou;

Ao meu querido esposo Julio César pelo amor e dedicação durante a realização deste trabalho, pelos vários finais de semana e feriados passados ao meu lado ... Dentro do laboratório, pela paciência em todas as tantas vezes que me ouviu falar dos problemas que estava enfrentando com os experimentos. Meu amor, muito obrigada! Você foi sem dúvida meu ponto de apoio e equilíbrio nos últimos quatro anos;

Às minhas queridas irmãs, Chirley e Kátia, meus primos Kênia e Johnatas, meus sogros, cunhados e cunhadas, sobrinhos e sobrinhas, pelo carinho, palavras de incentivo e confiança;

Ao Prof. Dr. Kaj Frank Jensen (Institute of Molecular Biology - University of Copenhagen) e ao Dr. Olof Björnberg (Department of Cell and Organism Biology Lund University) por nos ter cedido o plasmídeo pAG1 e as células S06645 e $S 06740$ usadas para expressão da EcDHODH, além da imensa atenção dispensada nas inúmeras vezes que recorremos a eles para sanar dúvidas; 
Ao Prof. Dr. Wayne L. Hubbell e ao Dr. Christian Altenbach (Jules Stein Eye Institute and Department of Chemistry and Biochemistry - University of California at Los Angeles) pela atenção em responder nossas dúvidas prontamente;

Ao Prof. Dr. Pietro Ciancaglini (FFCLRP/USP) pelas várias discussões e contribuições a este trabalho;

Aos professores do grupo de Biofísica Molecular Sérgio Mascarenhas (IFSC): Leila, Nelma e Otaciro. Em especial à Profa. Dra. Ana Paula Ulian Araújo pela ajuda na construção dos mutantes de EcDHODH;

Aos Técnicos do Grupo de Biofísica: João e Beto pelo apoio técnico e amizade, sempre prontos para ajudar com os equipamentos. Ao técnico e amigo José Fernando pela ajuda com o espectrômetro de RPE e com a simulação dos espectros de RPE, além da grande amizade. Com carinho especial agradeço à Andressa pela amizade e atenção que teve comigo durante a realização deste trabalho sempre me incentivando e principalmente pela paciência que teve ao me ensinar tantas coisas durante os últimos quatro anos. $A$ Gislaine por tornar o ambiente no laboratório mais agradável nos últimos meses com seu bom humor contagiante. E à querida Bel por toda ajuda, amizade e carinho;

Aos queridos amigos do Grupo de Biofísica: José Luiz, Assuero, Joci, Cris Nordi, Fernando Melo, Leandro, Priscila, Julio Damálio, Lia, Ana Paula, Regiane, Ceará, Daniel, Alessandra, Susana, Natália, Luiz Guilherme, Luiz, Célia, Débora, Fernanda, Ana Isabel, Carol, Kelven, Wânius e Nayara, pelo companheirismo, incentivo e apoio nas horas difíceis, mas principalmente pela disposição de cada um em me ceder muitas vezes um "pouquinho de suas visões" quando a minha tantas vezes não se fazia suficiente. Muito Obrigada a todos vocês!

À FAPESP, PRONEX, CNPq e CAPES pelo suporte financeiro para realização deste trabalho. 


\section{Resumo}

As enzimas diidroorotato desidrogenases (DHODHs) são flavo-enzimas que catalisam a oxidação do diidroorotato em orotato na quarta etapa da biossíntese de novo de nucleotídeos de pirimidina. Durante a rápida proliferação celular em mamíferos, a via de salvação de pirimidinas é insuficiente para suprir deficiências na síntese de nucleotídeos. Além disso, certos parasitas não possuem a via de salvação e contam somente com a biossíntese de novo para a produção de nucleotídeos. Por esta razão, DHODH se tornou um excelente alvo na busca por inibidores que interrompam a síntese de nucleotídeos. As enzimas DHODHs de E. coli (EcDHODH) e de $X$. fastidiosa (XfDHODH) são membros da classe 2 das $\mathrm{DHODH}$ e encontram-se associadas à membrana citoplasmática através de uma extensão em seu N-terminal, enquanto que DHODH de T. cruzi (TcDHODH), membro da classe 1 de DHODHs, é uma proteína citosólica. Neste trabalho, usamos uma combinação de metodologias de biologia molecular e bioquímica com técnicas espectroscópicas para obter informações estruturais e funcionais acerca da enzima DHODH. Assim, Ressonância Paramagnética Eletrônica (RPE) associada à marcação de spin sítio dirigida (SDSL) e simulação espectral foram empregadas para estudar a interação da EcDHODH com modelos de membrana. Mudanças na dinâmica estrutural das vesículas induzidas pela enzima foram monitoradas via marcadores de spin localizados em diferentes posições ao longo da cadeia acil de fosfolipídios. Além disso, técnicas de DNA recombinante e mutações sítio dirigidas foram utilizadas para produzir mutantes de EcDHODH no qual um sondas paramagnéticas foram seletivamente ligadas em resíduos localizados na extensão N-terminal da proteína para experimentos subseqüentes de RPESDSL. Esses são os primeiros experimentos de marcação de spin sítio dirigida realizados no Brasil e com os quais monitoramos a dinâmica experimentada na região do $\mathrm{N}$-terminal. Além disso, várias tentativas foram feitas para se expressar e purificar a enzima XfDHODH e a estabilidade estrutural da enzima $\mathrm{TCDHODH}$ na presença de um de seus inibidores naturais, o orotato, foi monitorada através de experimentos de Dicroísmo Circular (CD).

Palavras-chave: Diidroorotato desidrogenase. Marcação de spin sítio dirigida. Interação proteína-membrana. Relação estrutura-função. 


\begin{abstract}
Dihydroorotate dehydrogenases (DHODHs) are flavin-containing enzymes which catalyse the conversion of (S)-dihydroorotate to orotate, in the fourth step of the de novo biosynthesis of pyrimidine nucleotides. In rapidly proliferating mammalian cells, pyrimidine salvage pathway is insufficient to overcome deficiencies for nucleotide synthesis. Moreover certain parasites lack salvage enzymes, relying solely on the de novo pathway to produce nucleotides. Thus, DHODH has turned out an excellent target to the development of inhibitors that block nucleotide biosynthesis. E. coli $\mathrm{DHODH}(\mathrm{EcDHODH})$ and $X$. fastidiosa $\mathrm{DHODH}(\mathrm{XfDHODH})$ are class $2 \mathrm{DHODHs}$ found associated to cytosolic membranes through an N-terminal extension, whereas T. cruzi DHODH (TcDHODH) is a class $1 \mathrm{DHODH}$ localizated in the cytoplasm. In the present work, we used a combination of molecular biology and biochemical methodologies with spectroscopic techniques to obtain structural and functional information on DHODH. On one hand, Electronic Paramagnetic Resonance (EPR) associated with Site-directed Spin Labeling (SDSL) and spectral simulation were employed to study the interaction of EcDHODH with vesicles. Changes in vesicle dynamic structure induced by the enzyme were monitored via spin labels located at different positions along the phospholipid acyl chain and via spin labels located at enzyme specific positions. On the other hand, DNA techniques and site-directed mutagenesis were used to produce mutants of EcDHODH where a nitroxide spin probe was selectively attached to some residues located at the protein $\mathrm{N}$-terminal extension for subsequent EPR-SDSL experiments. These are the first site-directed spin labeling experiments performed in Brazil and the spectra allowed us to monitor dynamics experienced by those residues at the EcDHODH N-terminal domain. Furthermore, molecular biology and biochemical assays were employed with the objective of expressing and purifying XfDHODH and Circular Dichroism (CD) was utilized to probe the structural stability of TcDHODH in the presence of its natural inhibitor (orotate).
\end{abstract}

Keywords: Dihydroorotate dehydrogenase. Site-directed spin labeling. Membrane-protein inteaction. Structure-function relationship. 


\section{Lista de Figuras}

Figura 1 - Estrutura química dos nucleotídeos......

Figura 2 - Etapas da biossíntese de novo de nucleotídeos de pirimidina em procariotos.

Figura 3 - Reação de óxido-redução catalisada pela enzima DHODH.

Figura 4 - Estruturas tridimensionais de DHODHs pertencentes às classes 1 e $2 \ldots$ 28

Figura 5 Alinhamento seqüencial entre DHODHs da classe 2

Figura 6 - Comparação entre os sítios catalíticos de DHODHs das classes 1 e $2 \ldots$ 30

Figura 7 - Reação através da qual é obtida a proteína marcada com MTSL 33

Figura 8 - Estrutura cristalográfica da EcDHODH vista por ângulos diferentes........ 44

Figura 9 - Destaque do domínio N-terminal de EcDHODH..... 45

Figura 10 - Alinhamento seqüencial entre EcDHODH e HsDHODH....... 46

Figura 11 - Ambiente dos grupos FMN e orotato na molécula de EcDHODH....... 47

Figura 12 - Esquema ilustrativo do gene pyrD em pAG1. 54


56

Figura 14 - Esquema ilustrativo da $2^{\underline{a}}$ etapa da clonagem dos mutantes Y2C e F5C

Figura 15 - Estratégia da primeira etapa da clonagem de EcDHODH mutada em K8, F11, H19, F21, F23 e Q25.

Figura 16 - Esquema ilustrativo do gene codificador da EcDHODH em pAG1......... 64

Figura 17 - Esquema ilustrativo da clivagem dos fragmentos mutados em pAG1 e ligação desses fragmentos em PAG1A.

Figura 18 - Análise em gel de poliacrilamida das frações provenientes do teste de expressão da EcDHODH...

Figura 19 - Perfil de purificação da enzima EcDHODH a partir da coluna DEAESepharose e análise por eletroforese em SDS-PAGE.

Figura 20 - Análise por eletroforese em SDS-PAGE da purificação de EcDHODH em coluna de interação hidrofóbica.

Figura 21 - Reação de óxido-redução catalisada pela DHODH onde o DCIP é o aceptor de elétrons final na reação.

Figura 22 - Curva de absorção do DCIP em 610 nm.

Figura 23 - Espectros de RPE dos marcadores DPPTC e n-PC ( $n=5,10,12$ e 16) em vesículas mistas de DOPC/Triton X-100 e de DOPC/Triton X100/EcDHODH.

Figura 24 - Espectros de RPE em banda X de marcadores de spin incorporados a vesículas mistas de DOPG/Triton X-100 e de DOPG/Triton X- 
100/EcDHODH.

Figura 25 - Espectros de RPE em banda $X$ de marcadores de spin incorporados a vesículas mistas de DOPG/Triton X-100.....

Figura 26 - Espectros de RPE do marcador 5-PC incorporado a vesículas de DOPG/Triton X-100/EcDHODH.

Figura 27 - Sistemas de eixos usados nas simulações de espectros de RPE para os marcadores de spin 16-PC e DPPTC

Figura 28 - Estrutura geral de dispersões usadas em medidas de RPE.

Figura 29 - Espectros experimentais e simulados dos marcadores de spin DPPTC, 12-PC e 16-PC em vesículas mistas de DOPC/Triton X-100.

Figura 30 - Espectros experimental, calculado e das componentes individuais 1 e 2 do marcador de spin 5-PC em vesículas mistas de DOPC/Triton X-100 e DOPC/Triton X-100/EcDHODH.

Figura 31 - Espectros experimental, calculado e componentes individuais 1 e 2 do marcador de spin 10-PC em vesículas mistas de DOPC/Triton X-100 e DOPC/Triton X-100/EcDHODH.

Figura 32 - Estrutura cristalográfica da enzima EcDHODH...

Figura 33 - Espectros de RPE do marcador 5 PC incorporado a vesículas de DMPC/Triton X-100 e DMPC/Triton X-100/EcDHODH em diferentes temperaturas

Figura 34 - Espectros de RPE do marcador de spin 5-PC incorporado a vesículas multilamelares de DOPG/Triton X-100 e de DOPG/Triton X100/EcDHODH.

Figura 35 - Análise por RPE do efeito de ligantes da EcDHODH sobre a interação proteína-membrana

Figura 36 - Estrutura da enzima EcDHODH com destaque para os resíduos trocados por resíduos de císteina no domínio $\mathrm{N}$-terminal..

Figura 37 - Produção dos fragmentos sintéticos codificantes das versões mutadas de EcDHODH.

Figura 38 - Padrão de restrição dos clones em pAG1 e pAG1A

Figura 39 - Alinhamento seqüencial dos primeiros 280 pares de base codificantes da EcDHODH no vetor pAG1 e pAG1A.

Figura 40 - Seqüência de aminoácidos da enzima EcDHODH em pAG1 e pAG1A alinhada com os fragmentos mutados.

Figura 41 - Análise por eletroforese em SDS-PAGE $15 \%$ da expressão dos mutantes da enzima EcDHODH. 
Figura 42 - Analise por eletroforese em SDS-PAGE no nível de pureza dos mutantes de EcDHODH............................................................ 104

Figura 43 - Atividade enzimática dos mutantes da EcDHODH................................ 106

Figura 44 - Estrutura química do radical nitróxido...................................................... 107

Figura 45 - Mudanças na forma de linha de RPE em função da estrutura local onde se encontra o marcador de spin.

Figura 46- Espectros de RPE do marcador MTSL incorporado à enzima EcDHODH.

Figura 47 - Espectros de RPE do mutante F5C de EcDHODH marcado com R1 na ausência de Triton X-100 e após a readição de Triton X-100.

Figura 48 - Espectros de RPE para os mutantes de EcDHODH sem os resíduos nativos de cisteína em vesículas mistas de DOPC/Triton X-100.............

Figura 49 - Ângulos torsionais preferenciais para cadeias laterais nativas de cisteína e outras cadeias alifáticas e não-ramificadas............................ 116

Figura 50 - Sintomas da infecção da planta por CVC.

Figura 51 - Alinhamento seqüencial entre a estrutura primária de $\mathrm{HsDHODH}$, EcDHODH e XfDHODH...

Figura 52 - Esquema ilustrativo da primeira estratégia de clonagem para obtenção de XfDHODH.

Figura 53 - Esquema ilustrativo da estratégia de clonagem do gene codificante de XfDHODHmys no vetor de expressão pET32a.

Figura 54 - Expressão da XfDHODH avaliada por eletroforese em SDS-PAGE........

Figura 55 - Alinhamento da enzima DHODH de várias cepas da bactéria Xylella fastidiosa e da DHODH de E. coli.

Figura 56 - Resultado da expressão da XfDHODHmys-pET32a.

Figura 57 - Resultado da purificação da XfDHODHmys analisado em SDS-PAGE...

Figura 58 - Inseto Triatoma infestans conhecido popularmente como "Barbeiro"......

Figura 59- Alinhamento seqüencial entre DHODH de Lactococcus lactis, Trypanosoma cruzi, Homo sapiens e Xylella fastidiosa.........................

Figura 60 - Resultado da análise por eletroforese em gel SDS-PAGE da purificação da TcDHODH em coluna Ni-NTA.

Figura 61 - Espectros de CD a $20 \stackrel{\circ}{ } \mathrm{C}$ da enzima TcDHODH.

Figura 62 - Desnaturação térmica da TcDHODH avaliada por dicroísmo circular......

Figura 63 - Curva de transição das mudanças estruturais sofridas pela TcDHODH 


\section{Lista de Tabelas}

Tabela 1 - Lista dos genes pyr e correspondentes enzimas envolvidas na biossíntese de novo de nucleotídeos de pirimidina em procariotos, $\mathrm{T}$. cruzi e animais.

Tabela 2 - Coordenadas dos resíduos de aminoácidos de EcDHODH que foram mutados para resíduos de cisteínas.

Tabela 3 - Oligonucleotídeos sintetizados para criar as mutações em EcDHODH...

Tabela 4 - Oligonucleotídeos utilizados nas reações de PCR para obtenção dos mutantes de EcDHODH

Tabela 5 - Parâmetros obtidos a partir do melhor ajuste da simulação no programa NLSL dos espectros de RPE dos marcadores de spin DPPTC e $n-P C(n=5,10,12$ e 16) incorporados a vesículas mistas de DOPC/Triton X-100 e DOPC/Triton X-100/EcDHODH.

Tabela 6 - Condições testadas na expressão de XfDHODH em pET28a..................

Tabela 7 - Condições testadas na expressão da XfDHODHmys com os oito primeiros aminoácidos deletados. 


\section{Lista de Abreviaturas e Símbolos}

ACB

ACTase

BSA

CPSase

Cit C

CD

DCIP

DHO

DHOase

DHODH

DMPC

DNA

dNTP

DO

DOPC

DOPG

DPPTC

DTT

EC

EcDHODH

EDTA

ExPASy

FMN

HsDHODH

IPTG
Anidrase carbônica

Aspartato transcarbamilase

Albumina do soro bovino

Carbamoil-fosfato sintetase

Citocromo C

Dicroísmo Circular (Circular Dichroism)

2,6-dicloroindofenol

S-diidroorotato

Diidroorotatase

Diidroorotato desidrogenase

1,2-Dimiristoil-sn-Glicero-3-fosfatidilcolina

Ácido desoxirribonucléico

Desoxirribonucleotídeos trisfosfatos

Densidade ótica

Dioleoil-sn-Glicero-3-fosfatidilcolina

Dioleoil-sn-Glicero-3-fosfatidillicerol

Dipalmitoilfosfatidil tempo colina

DL-ditiotreitol

Enzyme committee number

Diidroorotato desidrogenase de Escherichia coli

Ácido etileno diamino tetracético

Expert Protein Analysis System

Flavina Mononucleotídeo

Diidroorotato desidrogenase de Homo sapiens

isopropil- $\beta$-D-tiogalactopiranosídeo 
ITS

LB

LIDHODHA

LIDHODHB

MOMD

MTSL

NCBI

NLSL

OVA

OPDCase

OPRTase

pAG1

5-PC

10-PC

12-PC

16-PC

PCR

PDB

pH

pl

PMSF

PRPP

pTZ57R/T

$Q_{0}$
Inibidor de tripsina de soja

Luria-Bertani

Forma A da diidroorotato desidrogenase de Lactococcus Lactis

Forma B da diidroorotato desidrogenase de Lactococcus Lactis

Ordem Microscópica - Desordem Macroscópica (Microscopic Order and Macroscopic Disorder)

(1-oxi-2,2,5,5-tetrametilpirrolina-3-metil) metanetiosulfonato

National Center for Biotechnology Information

Nonlinear Least-Square

Ovalbumina

orotidilato-fosfato descarboxilase

orotato-fosforribosil transferase

Plasmídeo codificador da EcDHODH

1-palmitoil-2-(5-doxil stearoil) fosfatidilcolina

1-palmitoil-2-(10-doxil stearoil) fosfatidilcolina

1-palmitoil-2-(12-doxil stearoil) fosfatidilcolina

1-palmitoil-2-(16-doxil stearoil) fosfatidilcolina

Reação em Cadeia da Polimerase (Polymerase chain reaction)

Protein Data Banking

Potencial Hidrogeniônico

Ponto isoelétrico

Fluoreto de phenylmetano sulfonila (phenylmethane sulfonyl fluoride)

5-fosforribosil-1-pirofosfato

Vetor de clonagem

2,3-dimetoxi-5-metil-1,4-benzoquinona 
React 3

React 4

RDHODH

RNA

RPE

SDS

SDSL

SDS-PAGE

TcDHODH

u.a.

UMP

X-GAL

XfDHODH

$x, y, z$

$x^{\prime}, y^{\prime}, z^{\prime}$

x", y", z"'

x"', y"', z"'

$\boldsymbol{R}_{\perp}$

$\mathbf{R}_{/ /}$

$\mathrm{S}_{\alpha}(\Psi)$

$\boldsymbol{\Psi}$

$A_{x x}, A_{y y}, A_{z z}$

$\Delta_{\circ}$
Tampão da enzima EcoRI

Tampão da enzima KpnI

Diidroorotato desidrogenase de rato

Ácido ribonucléico

Ressonância Paramagnética Eletrônica

Dodecil sulfato de sódio

Marcação de spin sítio dirigida (Site-directed Spin Labeling)

Eletroforese em gel de poliacrilamida - SDS (Sodium DodecylSulphate - Polyacrilamide Gel Electrophpresis)

Diidroorotato desidrogenase de Trypanosoma cruzi

Unidade arbitrária

Uridilato

5-bromo-4-cloro-3-indolil-beta-D-galactopiranosídeo

Diidroorotato desidrogenase de Xylella fastidiosa

Sistema de coordenadas do laboratório

Sistema de coordenadas de difusão molecular

Sistema de coordenadas do diretor local

Sistema de coordenadas magnético

Componente perpendicular da taxa de difusão rotacional

Componente paralela da taxa de difusão rotacional

Espectro de um fragmento de membrana

Ângulo entre o vetor diretor e o eixo z

Componentes do tensor hiperfino

Alargamento inomogêneo gaussiano 


\section{SUMÁRIO}

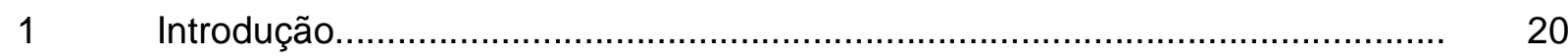

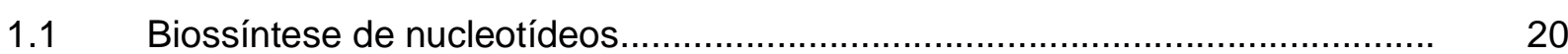

1.1.1 Síntese de novo de nucleotídeos de pirimidina............................................... 22

$1.2 \quad$ A enzima diidroorotato desidrogenase ....................................................... 25

1.3 Ressonância Paramagnética Eletrônica (RPE) de Sistemas Biológicos............ 32

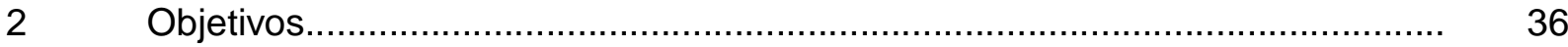

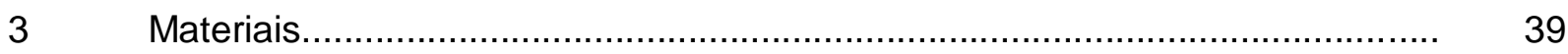

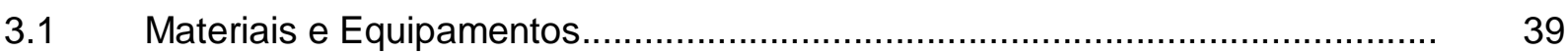

3.2 Reagentes, Resinas e Soluções.................................................................

$4 \quad$ Diidroorotato Desidrogenase de Escherichia coli........................................... 43

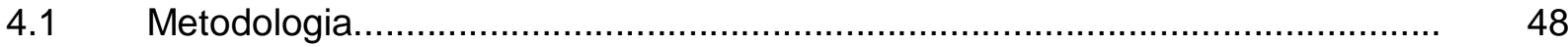

4.1.1 Expressão heteróloga - enzima EcDHODH............................................. 48

4.1.2 Extração da Enzima EcDHODH.............................................................. 49

4.1.3 Purificação da Enzima EcDHODH.......................................................... 49

4.1.4 Determinação da Concentração da Enzima...................................................... 50

4.1.5 Ensaio da atividade enzimática ............................................................ 51

4.1.6 Remoção do detergente.................................................................. 51

4.1.7 Ressonância Paramagnética Eletrônica..................................................... 51

4.1.8 Mutações sítio dirigidas na região N-terminal da enzima EcDHODH................ 53

4.1.9 Mutações sítio dirigidas na região N-terminal da enzima EcDHODH livre das

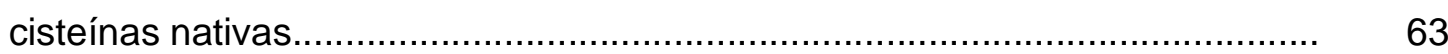

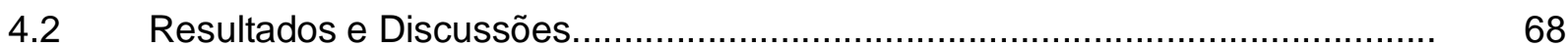

4.2.1 Expressão heteróloga da EcDHODH........................................................... 68

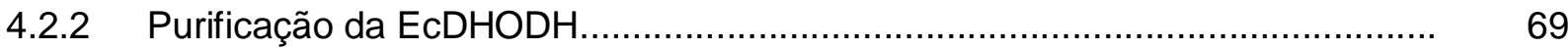

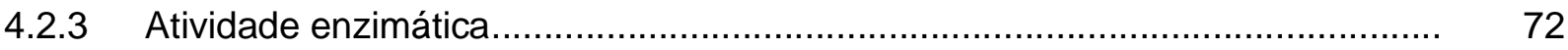

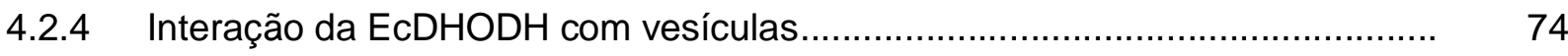


4.2.5 Marcação de spin sítio dirigida em EcDHODH................................................ 97

$5 \quad$ Diidroorotato Desidrogenase de Xylella fastidiosa............................................. 120



5.1.1 Estratégias de Clonagem............................................................................ 123

5.1.2 Expressão heteróloga da XfDHODH........................................................... 125

5.1.3 Purificação da XfDHODH mys................................................................... 127

$5.2 \quad$ Resultados e Discussões........................................................................... 128

5.2.1 Expressão e Solubilidade da enzima XfDHODH............................................ 128

5.2.2 Análise seqüencial.............................................................................. 129

5.2.3 Expressão e solubilidade da enzima XfDHODHmys........................................ 130

5.2.4 Purificação da enzima XfDHODHmys sob condições nativas........................... 131

$6 \quad$ Diidroorotato Desidrogenase de Trypanosoma cruzi........................................ 134

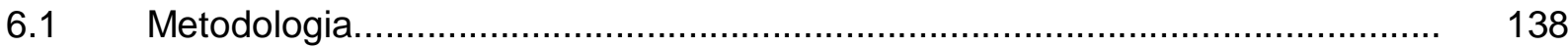

6.1.1 Expressão e Purificação da TcDHODH....................................................... 138

6.1.2 Dicroísmo circular..................................................................................... 139

6.2 Resultados e Discussões........................................................................ 140

6.2.1 Purificação da TcDHODH.......................................................................... 140

6.2.2 Análise da estabilidade térmica da TcDHODH.............................................. 141

$7 \quad$ Conclusões

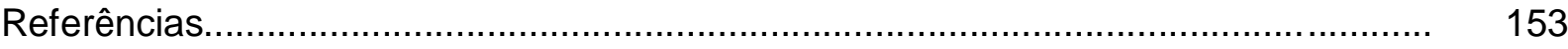

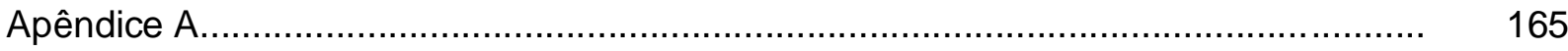




Introdução 


\section{Introdução}

Os nucleotídeos desempenham uma grande variedade de funções no metabolismo celular. São ativadores e inibidores em várias vias do metabolismo intermediário da célula, transportam a energia necessária para que reações metabólicas ocorram, são os elos químicos essenciais na resposta celular a hormônios e a outros estímulos extracelulares, atuam como componentes de coenzimas envolvidas no metabolismo celular. Além, é claro, de atuarem como as unidades fundamentais que constituem os ácidos desoxirribonucléicos (DNA) e ribonucléicos (RNA). A capacidade de armazenar e transmitir informação genética de uma geração a outra é uma condição fundamental para a vida. Portanto, todos os organismos vivos dependem da síntese de nucleotídeos [1]

Neste capitulo, as moléculas de nucleotídeos serão tratadas de maneira breve, sendo que a biossíntese dos nucleotídeos de pirimidina será descrita com maiores detalhes, e, atenção especial será dada à enzima diidroorotato desidrogenase (DHODH), a quarta enzima atuante em uma das vias biossintéticas desses nucleotídeos.

\subsection{Biossíntese de nucleotídeos}

Como comentado acima, os nucleotídeos desempenham uma variedade de funções em todas as células. Além de serem os precursores de DNA e RNA, eles são transportadores essenciais de energia química, como o trifosfato de adenosina (ATP), são cofatores de enzimas, como a Nicotinamida adenina dinucleotídeo (NAD) e a Flavina adenina dinucleotídeo (FAD), alguns nucleotídeos como a uradina difosfato-glicose (UDPglicose) são ativadores de intermediários biossintéticos e outros, como a adenosina 3',5'monofosfato cíclico (cAMP) atuam como mensageiros celular [1]. Essas funções fazem dos nucleotídeos moléculas extremamente importantes para vida celular. 
Os nucleotídeos são formados por uma molécula de açúcar (pentose), uma base nitrogenada e um ou mais grupos fosfato (Figura 1). As bases nitrogenadas podem ser purínicas (adenina $(A)$ e guanina $(G)$ ) ou uma pirimidínicas (citosina $(C)$, timina $(T)$ e uracila (U)). A pentose que compõe os nucleotídeos pode ser uma ribose ou uma desoxirribose.



Figura 1 - Estrutura química dos nucleotídeos. (A) bases nitrogenadas: Parte superior bases púrinicas; parte inferior bases pirimidínicas. (B) estrutura química de um nucleotídeo monofosfato.

A biossíntese de nucleotídeos pode ocorrer de duas maneiras distintas na natureza: pelas vias de novo ou através das vias de salvação conhecidas também como vias de recuperação. Aminoácidos, ribose-5'-fosfato, $\mathrm{CO}_{2}$ e $\mathrm{NH}_{3}$ são os precursores metabólicos com os quais a síntese de novo se inicia. É notável o fato de que as bases nitrogenadas livres não atuam como intermediários nas vias de novo, a estrutura do anel de purina é construída enquanto é ligada à ribose, durante o processo de adição de um ou de poucos átomos, de uma vez. O anel de pirimidina, por sua vez, é sintetizado como orotato ligado à ribose e, então, convertido nos nucleotídeos de pirimidina comuns à célula. Por outro lado, as vias de salvação reciclam as bases livres e os nucleosídeos liberados na quebra dos ácidos nucléicos [2]. 
Enquanto um grande número de parasitas é incapaz de sintetizar nucleotídeos purínicos através da biossíntese de novo e utilizam a via de recuperação para este propósito, a maioria dos organismos vivos possui a via de novo para produção de nucleotídeos de pirimidina. Além disso, muitos organismos que afetam a saúde humana, como por exemplo, a bactéria Helicobacter pylori (responsável por úlceras estomacais) e o parasita Plasmodium falciparum (causador da malária) não possuem a via de salvação para nucleotídeos de pirimidina. Isso indica que o equilíbrio imposto para suprir as quantidades necessárias de nucleotídeos de purina e pirimidina para a síntese dos ácidos nucléicos e desempenho de uma série de funções nas células é fornecido pela via de novo de nucleotídeos pirimidínicos [3]. Inibidores da síntese de novo de nucleotídeos de pirimidina formam um importante grupo de agentes quimoterapêuticos e células que dependem desta via metabólica são susceptíveis a tais inibidores. Como exemplo, células de linfócitos T e células cancerígenas dependem desta via para glicosilação de proteínas e síntese de lipídeos de membranas. Inibidores deste processo metabólico têm sido utilizados no tratamento de câncer e rejeição de órgãos transplantados [4,5].

\subsubsection{Síntese de novo de nucleotídeos de pirimidina}

Embora as estruturas primárias das enzimas que compõem esta via metabólica divirjam consideravelmente entre procariotos, protozoários, fungos e animais, a biossíntese de novo de pirimidinas representa um dos mais antigos processos metabólicos e todos os seus seis passos têm se mantido intactos durante a evolução [6].

A síntese de novo de nucleotídeos de pirimidina se inicia com a formação da molécula de carbamoilfosfato pela enzima carbamoil-fosfato sintetase (CPSase). Na segunda etapa, o carbamoil fosfato reage com aspartato para liberar $\mathrm{N}$-carbamilaspartato, sendo esta reação catalisada pela aspartato transcarbamilase (ACTase). Este passo é altamente regulado em bactérias e a enzima aspartato transcarbamilase é uma das enzimas 
alostéricas mais bem estudadas. O anel pirimidínico é fechado na terceira etapa da síntese para formar o diidroorotato pela remoção de água do N-carbamilaspartato, reação catalisada pela diidroorotatase (DHOase). No quarto passo da via, o diidroorotato é oxidado para liberar o orotato, um derivado de pirimidina. Essa reação é catalisada pela enzima diidroorotato desidrogenase $(\mathrm{DHODH})$. Uma vez formado o orotato, a cadeia lateral da ribose-5-fosfato, fornecida pelo 5-fosforribosil-1-pirofosfato (PRPP) é ligada a ele para liberar o orotidilato, reação esta intermediada pela enzima orotato-fosforribosil transferase (OPRTase). Por fim, a enzima orotidilato-fosfato descarboxilase (OPDCase) promove a descarboxilização do orotidilato gerando o uridilato (UMP), o que leva à formação de todos os outros nucleotídeos de pirimidina [7]. Na Figura 2 está apresentado um esquema ilustrativo desta via metabólica.



Figura 2 - Etapas da biossíntese de novo de nucleotídeos de pirimidina em procariotos. A síntese se inicia com a conversão da glutamina em glutamato e carbamoil fosfato pela enzima carbamoil-fosfato sintetase e termina com a formação do UMP. Seis reações enzimáticas são realizadas nesta via metabólica. Figura adaptada de Nelson e Cox (2002) [1]. 
Em animais, cinco das seis enzimas envolvidas na síntese de novo de nucleotídeos de pirimidina estão associadas em duas proteínas citoplasmáticas multifuncionais, CAD e UMP sintetase. O complexo CAD (CPSase, ACTase e DHOase) é codificado por um único gene, o pyr1a-1b-3-2, e o gene pyr5-6 codifica o complexo UMP sintetase (OPRTase e OPDCase). Esta observação foi feita por Jones em 1972 e confirmada alguns anos depois por ele mesmo $[7,8]$. Por outro lado, a enzima $\mathrm{DHODH}$, codificada pelo gene pyr4, ocorre independentemente e, além disso, é a única enzima nesta via localizada na membrana mitocondrial, todas as outras cinco enzimas localizam-se na região citoplasmática das células animais [3]. Em procariotos, a primeira enzima na via metabólica de novo de pirimidinas é composta por duas diferentes subunidades, a glutamina-amidotransferase e a carbamoil-fosfato sintetase $[9,10]$. Todas as seis enzimas envolvidas nesta via biosintética estão listadas na Tabela 1.

Tabela 1 - Lista dos genes pyr e correspondentes enzimas envolvidas na biossíntese de novo de nucleotídeos de pirimidina em procariotos, $T$. cruzi e animais. Tabela adaptada de Gao et al. (1999) [6].

Gene Enzima

$E C$

Procariotos T. cruzi Animais

\begin{tabular}{llllc}
\hline pyrAa & Pyr1a-1b & & Glutamina amidotransferase & 6.3 .5 .5 \\
pyrAb & Pyr1a-1b & Pyr1a-1b-3-2 & Carbamoil-fosfato sintetase & 6.3 .5 .5 \\
pyrB & Pyr2 & Pyr1a-1b-3-2 & Aspartato Carbamoiltransferase & 2.1 .3 .2 \\
pyrC & Pyr3 & Pyr1a-1b-3-2 & Diidroorotase & 3.5 .2 .3 \\
\hline pyrD & Pyr4 & Pyr4 & Diidroorotato desidrogenase & 1.3 .3 .1 \\
\hline pyrE & Pyr6-5 & Pyr5-6 & orotato-fosforribosil transferase & 2.4 .2 .10 \\
pyrF & Pyr6-5 & Pyr5-6 & orotidilado-fosfato descarboxilase & 4.1 .1 .23 \\
\hline
\end{tabular}

O interesse deste trabalho está voltado para o estudo da enzima diidroorotato desidrogenase. Portanto detalhes a respeito das outras cinco enzimas envolvidas na biossíntese de novo de UMP (CPSase, ACTase, DHOase, OPRTase e OPDCase) não 
serão aqui fornecidos. Para uma descrição mais detalhada a respeito destas enzimas, o leitor deve consultar os trabalhos de Iwahana et al. [11] e os trabalho de Jones $[7,8]$.

\subsection{A enzima diidroorotato desidrogenase}

Como discutido na seção anterior, a quarta enzima atuante na biossíntese de novo de UMP, o precursor de todos os nucleotídeos de pirimidina, é a enzima diidroorotato desidrogenase (EC. 1.3.3.1). Ela catalisa a oxidação do diidroorotato para orotato segundo um mecanismo enzimático do tipo ping-pong $[1,12]$.

A DHODH foi detectada pela primeira vez em 1953 por Lieberman e Kornberg em extratos da bactéria anaeróbica Zymobacterium oroticum (hoje denominada: Clostridium oroticum) [13]. Nos últimos 30 anos, entretanto, $\mathrm{DHODH}$ foi identificada como sendo o alvo farmacológico de uma série de compostos químicos e naturais, tais como: Arava (Leflunomide), aprovado para o tratamento de artrites reumatóides em humanos, isoxazol, triazina, ácido cinchonicínico e derivados de quinona [14-16]. Estes compostos interferem em reações descontroladas do sistema imune, auxiliam no combate de infecções parasitárias como malária e em terapias antivirais através da diminuição da concentração intracelular de nucleotídeos de pirimidina [17]. Com isso, o interesse em se conhecer esta enzima aumentou consideravelmente e atualmente uma série de estudos estão sendo desenvolvidos com o objetivo de identificar e analisar DHODHs dos mais variados organismos sob o ponto de vista funcional e estrutural.

No desempenho de suas funções biológicas, a DHODH utiliza a flavina mononucleotídeo (FMN, $\mathrm{C}_{17} \mathrm{H}_{21} \mathrm{~N}_{4} \mathrm{O}_{9} \mathrm{P}_{1}$ ) como cofator. $\mathrm{Na}$ primeira metade da reação enzimática, o FMN é reduzido enquanto o substrato diidroorotato é oxidado. Na segunda parte da reação, o FMN é reoxidado $\left(\mathrm{FMNH}_{2}\right.$ é convertido em FMN) através do auxílio de uma terceira molécula que atua como aceptor de elétrons (Figura 3) [18]. 




Figura 3 - Reação de óxido-redução catalisada pela enzima DHODH. O hidrogênio $H^{*}$ é transferido para FMN como um híbrido, e o hidrogênio $H^{\prime}$ é perdido como um próton. No caso da enzima humana, ubiquinona $(Q)$ é o agente oxidante.

De acordo com a estrutura primária e localização celular, as enzimas DHODH de diferentes organismos, podem ser divididas em duas classes (classes 1 e 2) [19]. As enzimas da classe 1, encontradas principalmente em bactérias Gram-positivas, podem ser subdivididas nas classes 1A, 1B e em uma nova classe (1S) encontrada recentemente em Sulfolobus solfataricus [20]. As DHODHs das classes 1A e 1B são citosólicas, enquanto que os membros da classe 2 encontradas em bactérias Gram-negativas e eucariotos, apresentam uma extensão na região $\mathrm{N}$-terminal que permite a associação dessas enzimas com membranas [21,22]. A identidade seqüencial entre as enzimas da classe 1 e aquelas associadas a membranas é relativamente baixa (menor que $20 \%$ ). Outra diferença entre as duas classes de enzimas diz respeito ao aceptor natural de elétrons utilizado na reoxidação do grupo flavina, 
Até o presente momento, as estruturas cristalográficas de $6 \mathrm{DHODHs}$ foram determinadas: DHODH de Lactococcus lactis (LIDHODH) [23], Trypanosoma cruzi (TcDHODH) [24], todas membros da classe 1 das DHODHs; DHODH humana (HsDHODH) [21], DHODH de rato (RDHODH) [25], DHODH de Plasmodium falsiparum (PfDHODH) [26] e de E. coli $(\mathrm{EcDHODH})$ [22], essas pertencentes à classe 2. Em termos gerais, as enzimas de ambas as classes, apresentam uma estrutura terciária similar, se enovelando em um motivo barril $\alpha / \beta$, que consiste de uma região central formada por 8 fitas beta paralelas rodeadas por $8 \alpha$-hélices. No topo do barril, três fitas $\beta$ antiparalelas formam uma espécie de "tampa" que cobre o sítio redox. O fundo do barril é formado um par de fitas $\beta$ antiparalelas. As enzimas pertencentes à classe 2 das $\mathrm{DHODHs}$, como por exemplo HsDHODH e EcDHODH, contêm na região N-terminal um motivo adicional composto de três hélices, responsável pela interação da enzima com a membrana, e que se encontra ausente na estrutura de DHODHs da classe 1. Além disso, DHODHs da classe 2 apresentam um longo "loop" que conecta uma das a-hélices do N-terminal ao fundo do barril (Figura 4) $[21,22]$.

A bactéria de fermentação do leite, Lactococcus lactis, é o único organismo conhecido que produz duas diferentes DHODHs funcionais, LIDHODHA e LIDHODHB [27]. Essas duas enzimas são excelentes representantes dos subgrupos $1 \mathrm{~A}$ e $1 \mathrm{~B}$ das diidroorotato desidrogenases da classe 1. As DHODHs de L. lactis vêm sendo estudadas como protótipos da classe 1 de DHODHs e suas estruturas foram determinadas tanto no estado nativo quanto em complexo com orotato $[16,23,28]$. Essas duas enzimas diferem em organização estrutural e no uso de aceptor de elétrons. A LIDHODHA é um homodímero, como a maioria das DHODHs pertencentes à classe 1, contém o grupo prostético FMN localizado no final do C-terminal da folha $\beta$ no topo do barril e utiliza fumarato como aceptor natural de elétrons $[23,28]$. Por outro lado, LIDHODHB é um heterotetrâmero composto por dois diferentes polipeptídeos codificados por dois genes diferentes co-transcritos, possui FMN, flavina adenina dinucleotídeo (FAD) e $\mathrm{Fe}_{2} \mathrm{~S}_{2}$ como centros redox e utiliza $\mathrm{NAD}^{+}$como aceptor de elétrons [29-31]. A cadeia polipeptídica de LIDHODHA e a maior subunidade de 
LIDHODHB possuem o mesmo número de resíduos, entretanto, a identidade seqüencial entre as duas é de apenas $30 \%$. A estrutura cristalográfica das duas DHODHs de L. lactis revelam que o sítio de ligação da flavina se encontra na base do barril, com o anel aromático da molécula de orotato paralelo à molécula de FMN [23].

A LIDHODH

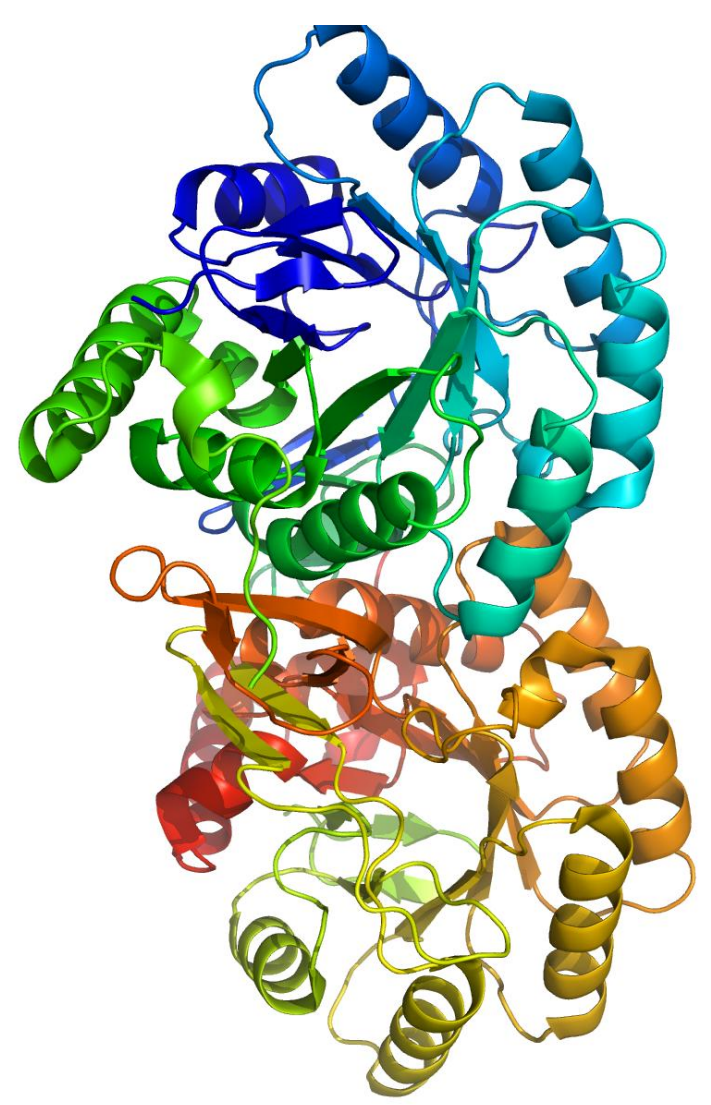

\section{B HsDHODH}

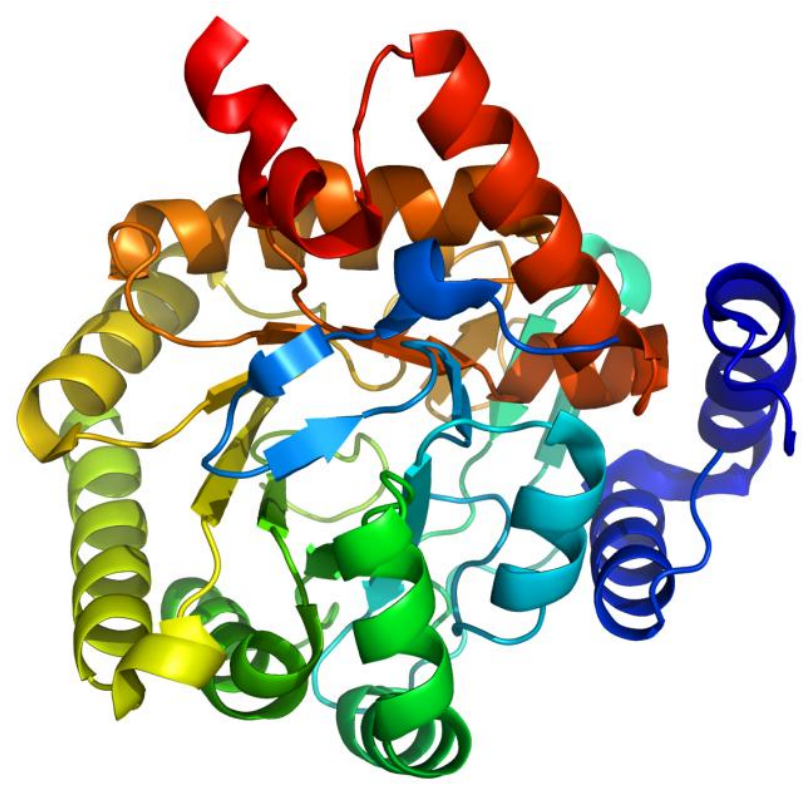

Figura 4 - Estruturas tridimensionais de DHODHs pertencentes às classes $1 \mathrm{e} \mathrm{2.}(\mathrm{A})$ LIDHODHA e (B) HsDHODH. Ambas as proteínas enovelam-se um motivo do tipo barril $\alpha / \beta$. LIDHODH é dimérica enquanto HsDHODH é monomérica. Além disso, a DHODH humana apresenta um domínio adicional composto por três hélices, domínio este responsável pela associação da enzima à membrana mitocondrial.

As DHODHs associadas a membranas (classe 2) são monoméricas e utilizam quinonas do sistema respiratório como seus aceptores de elétrons. Um aspecto interessante de DHODHs da classe 2 é que o domínio N-terminal das enzimas pertencentes a esta classe e que possuem estruturas cristalográficas conhecidas apresenta variações significativas no comprimento e orientação das hélices. Isso pode ser explicado pelo 
pequeno número de resíduos conservados em suas extensões $\mathrm{N}$-terminal como mostrado na Figura 5. O alinhamento seqüencial revela que somente dez dos 40 primeiros resíduos na seqüência da EcDHODH são conservados em HsDHODH e RDHODH. É provável que essas variações no $\mathrm{N}$-terminal sejam a origem do comportamento diferenciado de inibidores testados em HsDHODH e RDHODH [32]. Isto possibilita o desenho de inibidores que sejam específicos para um dado organismo, como demonstrado por estudos da estrutura-atividade de DHODHs feitos por Coperland et al. [33].

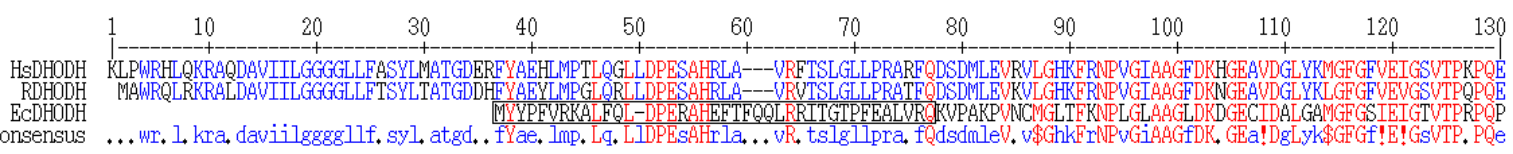

Figura 5 - Alinhamento seqüencial entre DHODHs da classe 2: HsDHODH, RDHODH e EcDHODH. Os resíduos conservados em todas as enzimas são mostrados em vermelho, enquanto que os resíduos conservados apenas em duas das enzimas são mostrados em azul. O domínio Nterminal da EcDHODH está destacado pela caixa preta.

Outro aspecto muito interessante nas diferenças existentes entre as DHODHs das duas classes, é que o resíduo no sítio ativo que media a oxidação específica do diidroorotato é uma cisteína nas enzimas da classe 1, enquanto que nas DHODHs da classe 2 é uma serina [19,34]. Além disso, resíduos circundantes à serina catalítica (como Ser 214, Pro216, Asp217 - resíduos numerados de acordo com HsDHODH) e que também têm um papel crucial para a atividade catalítica dessas enzimas são conservados nas duas classes de DHODHs (Figura 6). 
A

\begin{tabular}{|c|c|}
\hline L. lactis (DHODHA) & -NLSCPNVPGKPQLAY- \\
\hline E. coli (EcDHODH & -NISSPNTPGLRTLQY- \\
\hline H. sapiens $(\mathrm{HsDHODH})$ & $\begin{array}{c}\text {-NVSSPNTAGLRSLQG- } \\
\mid \begin{array}{l}\mid \\
212\end{array}\end{array}$ \\
\hline
\end{tabular}



Figura 6 - Comparação entre os sítios catalíticos de DHODHs das classes 1 e 2. (A) Alinhamento seqüencial entre a DHODH de E. coli (resíduos 172-186), DHODH de L. lactis (resíduos 127 a 141) e HsDHODH (resíduos 212 a 226). Os resíduos sublinhados formam um loop na DHODHA, conectando uma folha- $\beta$ a uma $\alpha$-hélice [34]. Vizinhanças do grupo FMN em (B) EcDHODH e (C) LIDHODHA [23]. O resíduo de cisteína catalítico na família 1 é trocado por um de serina na família 2 das DHODHs. Figura adaptada de Björnberg et al. [22].

Embora o interesse pelas DHODHs venha crescendo a cada ano, ainda não há na literatura trabalhos que revelem a natureza da interação entre as DHODHs da classe 2 com membranas. Esse fato provavelmente se deve à dificuldade em se trabalhar com proteínas com alto caráter hidrofóbico, pois essas proteínas são na maioria dos casos muito instáveis e necessitam da presença constante de detergentes para evitar a formação de agregados. Grande parte dos detergentes utilizados na solubilização de proteínas de membrana impossibilita a utilização de determinadas técnicas espectroscópicas, tais como dicroísmo circular (CD) e absorção ótica, por serem oticamente ativos na faixa de comprimento de onda onde essas técnicas normalmente operam. Além disso, a dificuldade em se expressar proteínas de membrana na forma solúvel e em quantidades razoáveis para a realização de ensaios espectroscópicos e biológicos pode ser muito grande. 
Neste trabalho, procuramos mostrar evidências diretas da ligação da EcDHODH (membro da classe 2) com sistemas modelo de membrana e discutimos as implicações desta interação sobre a função da proteína. Para isso, usamos Ressonância Paramagnética eletrônica (RPE), marcadores de spin, marcação de spin sítio dirigida (SDSL) e simulação espectral, com o intuito de monitorar mudanças induzidas pela EcDHODH na vizinhança de fosfolipídios marcados e incorporados nos sistemas de membrana modelo, bem como na vizinhança do marcador de spin metanetiosulfonato (MTSL) em posições específicas da enzima. O uso de rotinas de simulação espectral específica nos permitiu caracterizar os espectros de RPE em termos de mudanças na polaridade e mobilidade nas vizinhanças das moléculas de fosfolipídios marcados. A técnica de RPE é uma técnica muito útil, que faz uso de íons de metais de transição ou marcadores de spin, normalmente radicais nitróxidos ligados a moléculas como fosfolipídios ou resíduos de cisteína em proteínas, para monitorar mudanças na vizinhança do grupo repórter [35-38]. Tais variações podem ser relacionadas com uma variedade de processos biológicos relevantes, assim como, mudanças na conformação da proteína [39-41], interações lipídio-proteína [42,43] e com a estrutura dinâmica estrutural de membranas biológicas e membranas modelo [44-46].

Outro aspecto desenvolvido neste trabalho foi a tentativa em produzir a enzima DHODH da bactéria Xylella fastidiosa na forma recombinante. A Xylella fastidiosa é uma bactéria fitopatogênica responsável pela "Praga do amarelinho" que ataca aproximadamente 1/3 dos pés de laranja, especialmente nos estados de São Paulo e Minas Gerais [47]. A XfDHODH é membro da classe 2 das DHODHs e até o presente momento não há nenhum estudo direto voltado para esta enzima, embora outras proteínas pertencentes à bactéria Xylella fastidiosa tenham se tornado alvo de muitos estudos após a publicação do genoma completo desse organismo, devido à alta patogenicidade desta bactéria para o setor citricultor. Em vista deste apelo sócio/econômico, nosso interesse inicial neste projeto foi voltado para a enzima XfDHODH, onde procurávamos evidências diretas da sua interação com membranas. No entanto no decorrer do desenvolvimento deste trabalho acabamos 
voltando nosso foco principal para a enzima de E. coli, por razões experimentais como será descrito adiante.

Por fim, nossa atenção foi voltada ainda para a DHODH do parasita Trypanosoma cruzi (parasita causador da doença de Chagas). Embora alguns estudos já tenham sido realizados com esta enzima, inclusive a determinação de sua estrutura cristalográfica [24,48,49], nosso interesse residiu na análise por dicroísmo circular da estabilidade térmica da TcDHODH, na ausência e na presença de orotato [50].

\subsection{Ressonância Paramagnética Eletrônica (RPE) de Sistemas Biológicos}

A técnica de RPE é uma técnica útil, que faz uso de íons de metais de transição ou marcadores de spin, normalmente radicais nitróxidos ligados a moléculas como fosfolipídios ou resíduos de cisteína em proteínas, para monitorar mudanças na vizinhança do grupo repórter [35-37]. Tais variações podem ser relacionadas com uma variedade de processos biológicos relevantes, assim como, mudanças na conformação da proteína [39-40], interações lipídio-proteína [42,43] e com a estrutura dinâmica estrutural de membranas biológicas e membranas modelo [44-46].

Marcadores de spin têm sido usados freqüentemente na busca por informações estruturais e dinâmicas em macromoléculas [36], mas a falta de sítios paramagnéticos ou com afinidade por marcadores de spin em muitos desses sistemas fez com que a sua aplicação fosse sempre limitada. Recentemente, novos métodos foram desenvolvidos para superar três maiores dificuldades: sensibilidade, seletividade e versatilidade. Sensibilidade para se trabalhar com quantidades limitadas de amostra e seletividade para ligar marcadores a um sítio específico na cadeia polipeptídica. A introdução de ressonadores do tipo "loop-gap" foi essencial para resolver o problema da sensibilidade [51]. O 
desenvolvimento de técnicas de biologia molecular (como as de mutação sítio dirigida) permitiu suplantar os problemas relacionados à seletividade e versatilidade.

A técnica de marcação de spin sítio dirigida (SDSL) surgiu como uma ferramenta bastante promissora na determinação de estruturas secundárias e terciárias de proteínas. Tanto proteínas solúveis quanto de membrana e com peso molecular arbitrário são passíveis de estudo por SDSL com resolução temporal na escala de milissegundos e concentrações de amostra na ordem de 100 pmol.

A estratégia da SDSL envolve a introdução de um radical nitróxido em uma posição específica da proteína. Uma mutação sítio dirigida é normalmente usada para esse fim, sendo um resíduo nativo trocado por um de cisteína, para a posterior reação do seu grupo sulfidrílico com um marcador de spin adequado (Figura 7). Até hoje, o reagente metanotiosulfonato (MTSL) tem sido o mais utilizado para fins de SDSL, embora outros tipos também já tenham sido empregados. Perturbações no enovelamento, estabilidade térmica ou funcional devido à introdução do marcador de spin parecem não ser um problema limitante para a maioria dos casos investigados $[25,35,37,55]$. Por fim, SDSL ainda possui resolução temporal compatível com aquela na qual normalmente ocorrem fenômenos como mudanças conformacionais em estruturas de proteínas e a possibilidade da escolha de um marcador de spin que melhor se adéqüe ao problema em questão.


Figura 7 - Reação através da qual é obtida a proteína marcada com MTSL. A cadeia lateral marcada é denominada cadeia lateral R1. Figura adaptada de: Frazier et al. [52]. 
Obviamente, as aplicações independentes de marcadores de spin ou de técnicas de biologia molecular em problemas de interesse biológico constituem metodologias muito bem estabelecidas, mas o início de seu emprego conjunto para investigações estruturais e dinâmicas de proteínas em geral, o que forma o alicerce de funcionamento da técnica de SDSL-RPE, se deu apenas no final da década de 80 [53], com sua utilização de forma mais generalizada e corriqueira em diversos laboratórios sendo conseguida no final dos anos 90 . Desde então, com destaque para os últimos anos, problemas envolvendo tanto proteínas de membrana quanto proteínas solúveis se valeram de novas análises feitas à luz da espectroscopia de SDSL-RPE como, por exemplo: mudanças estruturais na subunidade $\alpha$ da proteína G [41]; formação de fibras amilóides associadas a processos neurodegenerativos [54]; bases estruturais da transdução de energia [39]; determinação da estrutura de complexos protéicos [40]. Mais exemplos podem ser obtidos na recente revisão de Fanucci e Cafiso [55].

Uma busca nos bancos de dados disponíveis, como o ISI Web of Science (http://www.webofscience.com), mostra que no Brasil, apesar da existência de vários grupos de excelência atuando tanto no uso de marcadores de spin e RPE quanto de técnicas de biologia molecular em problemas biologicamente relevantes, a metodologia de SDSL-RPE ainda não se encontra estabelecida. Portanto, o presente projeto se propôs a dar o primeiro passo nesse sentido. Com um objetivo mais geral (objetivos específicos são apresentados no próximo capítulo) de voltar a infra-estrutura de RPE e de técnicas de biologia molecular/bioquímica existentes no Grupo de Biofísica Molecular do Instituto de Física de São Carlos (IFSC/USP), assim como a experiência adquirida pelo grupo na área de Biofísica Molecular, para temas passíveis de estudo por SDSL-RPE. Com base no exposto na seção anterior, pudemos verificar que a enzima diidroorotato desidrogenase (DHODH) de alguns organismos era um candidato promissor para a técnica de SDSL-RPE, o que nos motivou, então, a incluir estudos por SDSL da enzima DHODH de classe 2 , com sua extensão no Nterminal como alvo, no elenco de experimentos buscados ao longo do desenvolvimento do presente projeto de tese. 
Objetivos 


\section{Objetivos}

O propósito deste trabalho foi a realização de estudos estruturais e funcionais de diidroorotato desidrogenases dos seguintes organismos: Escherichia coli (EcDHODH), Xylella fastidiosa (XfDHODH) e Trypanosoma cruzi (TcDHODH). Para tanto nos valemos de técnicas espectroscópicas, com ênfase na Ressonância Paramagnética Eletrônica. Os objetivos iniciais específicos incluíram:

$\checkmark$ Expressão da EcDHODH recombinante e purificação por meio de técnicas cromatográficas.

$\checkmark \quad$ Incorporação da EcDHODH em vesículas lipídicas marcadas com radical nitróxido em diferentes posições da cadeia acil de fosfolipídios.

$\checkmark \quad$ Realização de experimentos de RPE para a obtenção de espectros de marcadores de spin em diferentes posições da cadeia acil de fosfolipídios incorporados a vesículas lipídicas quando da adição da enzima EcDHODH.

$\checkmark \quad$ Simulação dos espectros obtidos para situações em que houve interação da enzima com a vesícula, evidenciada por mudanças qualitativas nos espectros dos marcadores de spin.

$\checkmark \quad$ Estudos por SDSL para investigação da dinâmica experimentada pela região da enzima EcDHODH que contém a extensão $\mathrm{N}$-terminal. Para isso mutações nessa região, que provavelmente realiza o contato da enzima com a membrana, são introduzidas, fazendo-se uso de técnicas de DNA recombinante onde códons codificadores de resíduos específicos são substituídos (um de cada vez) por códons para císteina.

$\checkmark \quad$ Expressão e purificação da enzima XfDHODH para repetição das etapas descritas acima envolvendo a EcDHODH.

$\checkmark \quad$ Expressão e purificação da enzima TcDHODH. 
Estudos da estabilidade estrutural da TcDHODH recombinante com o uso da espectroscopia de dicroísmo circular, avaliando o papel exercido pelo produto da reação orotato sobre a estabilidade estrutural da enzima. 
Materiais 


\section{Materiais}

Nesta seção estão listados os materiais e equipamentos utilizados na realização de todos os experimentos apresentados neste trabalho.

\subsection{Materiais e Equipamentos}

- $\quad$ Espectrômetro de RPE modelo E109 (Varian) operando em modo de onda contínua e equipado com ponte de microondas em banda $X(9,5 \mathrm{GHz})$;

- $\quad$ Controlador de temperatura VT Controler E257-X (Varian);

- $\quad$ Espectropolarímetro modelo J-720 (Jasco) equipado com banho de água (TC100) e controlador de temperatura Jasco PFD 425S.

- $\quad$ Centrífuga refrigerada Sorval modelo 5B e RC5C; centrífuga refrigerada Eppendorf modelo 5804R; centrífuga de bancada Eppendorf modelo 5414D;

- $\quad$ Espectrofotômetros Hitachi modelos U-2001 e U-2801;

- $\quad$ Sistema para cromatografia de alta e baixa pressão ÄKTA purifier system (GE Healthcare);

- $\quad$ Sistema para eletroforese Bio-rad;

- $\quad$ Sistema centrífugo/liofilizador Savant (Speedvac);

- $\quad$ Cela chata de quartzo Avanti;

- $\quad$ Cubeta retangular de quartzo Jasco - caminho ótico de $0,1 \mathrm{~cm}$;

- $\quad$ Agitador refrigerado Forma Scientific;

- $\quad$ Termociclador Mastercycler - Eppendorf.

- $\quad$ Sonicador Fisher Scientific modelo 500;

- $\quad$ Concentradores Amicon Ultra-15 Centrifugal Filter Devices (Limite nominal de peso molecular (NMWL - Nominal Molecular Weight Limit) igual a 10kDa) - Milipore; 
- $\quad$ Agitador de tubos /Vortex (Proemix);

- $\quad$ Transiluminador BioAgency.

\subsection{Reagentes, Resinas e Soluções}

Os reagentes para reação em cadeia da polimerase (PCR), oligonucleotídeos, enzimas de restrição Xhol, Hpa1, BamH1, EcoRl, Kpnl e seus respectivos tampões foram obtidos da Invitrogen Life Technologies (EUA). A enzima TAq DNA polimerase de alta fidelidade (High fidelity), tampão High Fidelity PCR, X-Gal (5-bromo-4-cloro-3-indolil-beta-Dgalactopiranosídeo, e o vetor de clonagem pTZ57R/T (InsT/Aclone ${ }^{\mathrm{TM}}$ PCR Product Cloning Kit) foram obtidos da Fermentas (Canadá). A enzima $T_{4}$ DNA Ligase e os quites para extração de DNA "Kit Wizard ${ }^{\circledR}$ SV Gel and PCR Clean - Up System" e "Wizard ${ }^{\circledR}$ Plus SV Minipreps DNA Purification System" foram adquiridos da Promega (EUA). O antibiótico ampicilina foi adquirido da empresa USB (EUA).

As colunas DEAE Sepharose, Phenyl Sepharose e G-25 foram compradas da Amersham Biosciences (Suécia). A resina calbiosorb adsorvent foi adquirida da empresa Calbiochem (EUA) e a resina de níquel Ni-NTA foi obtida da Quiagen (EUA).

Os reagentes Tris, $\mathrm{NaCl}, \mathrm{MgCl}_{2}, \mathrm{NaH}_{2} \mathrm{PO}_{4}, \mathrm{Na}_{2} \mathrm{HPO}_{4}, \mathrm{CaCl}_{2},\left(\mathrm{NH}_{4}\right)_{2} \mathrm{SO}_{4}$, acrilamida, $\mathrm{NaOH}, \mathrm{HCl}$, Triton X-100, glicerol, Dodecil sulfato de sódio (SDS), $\beta$-mercaptoetanol, ácido

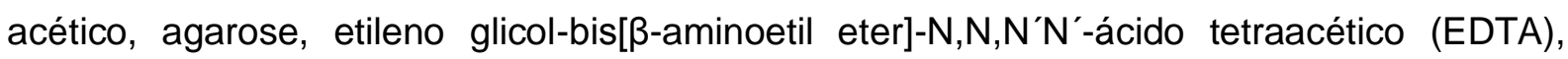
brometo de etídeo, clorofórmio, acetonitrila, DL-ditiotreitol (DTT), isopropil $\beta-D$ tiogalactopiranosideo (IPTG), meio de cultura Luria-Bertani (LB), diidroorotato, orotato, 2,6dichloroindophenol (DCIP), albumina do soro bovino (BSA - $66 \mathrm{kDa}$ ), ovalbumina (OVA - 45 kDa), anidrase carbônica (ACB - $30 \mathrm{kDa}$ ), inibidor de tripsina de soja (ITS - 20,1 kDa), e citocromo C (cit C - 12,4 kDa) foram obtidos da empresa Sigma-Aldrich Chemical (EUA).

Os fosfolipídios DOPC (Dioleoil-sn-Glicero-3-fosfatidilcolina), DOPG (Dioleoil-snGlicero-3-fosfatidilglicerol) e DMPC (1,2-Dimiristoil-sn-Glicero-3-fosfatidilcolina) bem como os marcadores de spin [1-palmitoil-2-(n-doxil stearoil)] fosfatidilcolina $(n=5,10,12$ e 16) e 
Dipalmitoilfosfatidil tempo colina (DPPTC) foram adquiridos da Avanti Polar Lipids (EUA) e o marcador de spin MTSL [(1-oxi-2,2,5,5-tetrametilpirrolina-3-metil) metanetiosulfonato] foi comprado da empresa Toronto Research Chemicals (Canadá). 


\section{Diidroorotato Desidrogenase de Escherichia coli}




\section{Diidroorotato Desidrogenase de Escherichia coli}

A enzima diidroorotato desidrogenase de Escherichia coli (EcDHODH) membro da classe 2 de DHODH é uma proteína monomérica, com massa molecular de 37 kDa, pl de 7,6 e dependente de FMN. Assim como todas as enzimas pertencentes à classe 2 de DHODHs, a EcDHODH também apresenta uma extensão $\mathrm{N}$-terminal responsável pela interação da enzima com a membrana celular [56].

A estrutura tridimensional da EcDHODH, publicada em 2002 por Norager et al. [22], permitiu uma análise comparativa entre as diferentes classes de DHODHs o que contribuiu para a elucidação de várias das diferenças estruturais e funcionais observadas entre as duas classes. Embora a EcDHODH pertença a um organismo pouco patogênico e muito bem conhecido, o seu estudo torna-se muito interessante e importante devido ao fato de esta enzima ser expressa e purificada em sua forma "completa", diferentemente da enzima humana que pôde ser estudada apenas em uma forma truncada (com parte do domínio Nterminal removido) [21]. O conhecimento da interação EcDHODH-membrana pode possibilitar comparações com outras DHODHs, o que ajudaria na busca por inibidores específicos.

A estrutura cristalográfica da EcDHODH revelou a existência de quatro moléculas na unidade assimétrica do cristal, sendo que duas delas estão associadas por dois eixos não cristalográficos e interagem entre si através dos seus domínios N-terminal. Tal interação pode explicar o porquê de a proteína se comportar como um dímero em solução, como observado por Björnberg et al. [34].

A estrutura secundária da EcDHODH é composta por 11 a-hélices, 4 hélices $3_{10}$ e 13 fitas $\beta$. Similarmente à estrutura de outras DHODHs (LIDHODHA [23], HsDHODH [21]), enovela-se em um barril $\alpha / \beta$, composto por 8 fitas beta paralelas rodeadas por 12 hélices, com moléculas de FMN e orotato situadas no topo do barril. As cinco fitas restantes formam duas folhas $\beta$ antiparalelas, uma no topo do barril cobrindo a molécula de FMN e outra 
localizada no fundo do barril. Além disso, existe ainda o domínio composto pelo $\mathrm{N}$-terminal estendido, composto por duas $\alpha$-hélices e uma hélice $3_{10}$, que se encontra interligado ao sítio catalítico do barril por um longo "loop" (Figura 8). Norager et al. [22] realizaram ensaios com uma versão truncada da EcDHODH (os resíduos 2 a 30 foram deletados) e concluíram que o N-terminal da EcDHODH é importante para: (1) interação com quinonas do sistema respiratório, (2) a alta hidrofobicidade da EcDHODH na presença de sal e (3) a interação da enzima com membranas celulares. Além disso, seus resultados revelam que a estrutura protéica é estabilizada por interações entre a primeira hélice do domínio $\mathrm{N}$-terminal e as duas hélices do C-terminal localizadas no barril (Figura 8B). Essas interações envolvem somente um lado da hélice do domínio N-terminal, deixando o outro lado disponível para interagir com a membrana bacteriana [22].

A



B

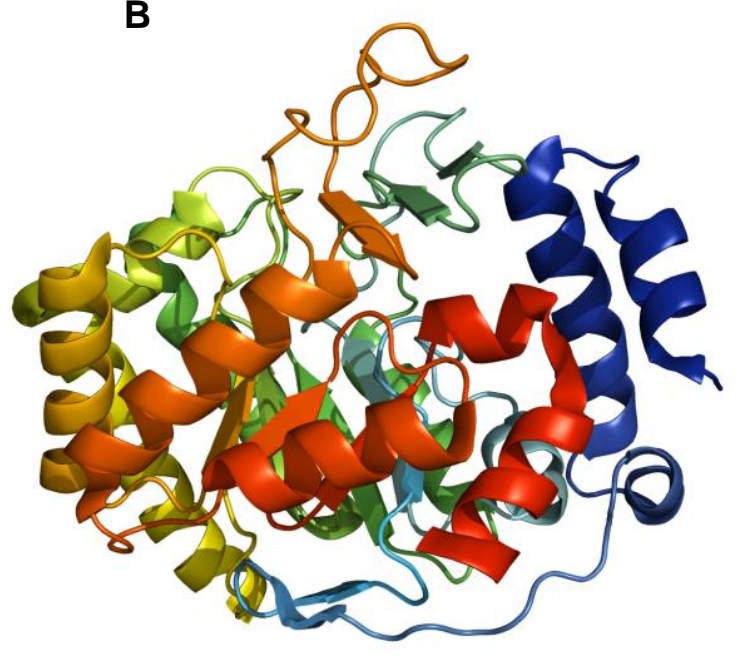

Figura 8 - Estrutura cristalográfica da EcDHODH vista por ângulos diferentes. As figuras foram preparadas com programa Pymol [57].

A Figura 9 mostra em destaque o domínio N-terminal da EcDHODH com os resíduos hidrofóbicos mostrados em azul, hidrofílicos carregados em vermelho e hidrofílicos não carregados em verde. É notável que a parte exposta ao solvente não possua um excesso de resíduos hidrofóbicos e que não há uma concentração de resíduos carregados orientados 
em direção ao barril. Essa distribuição de resíduos no $\mathrm{N}$-terminal deve possibilitar a ligação da enzima à membrana, mas evidencia que ela não seja uma proteína integral de membrana [22].

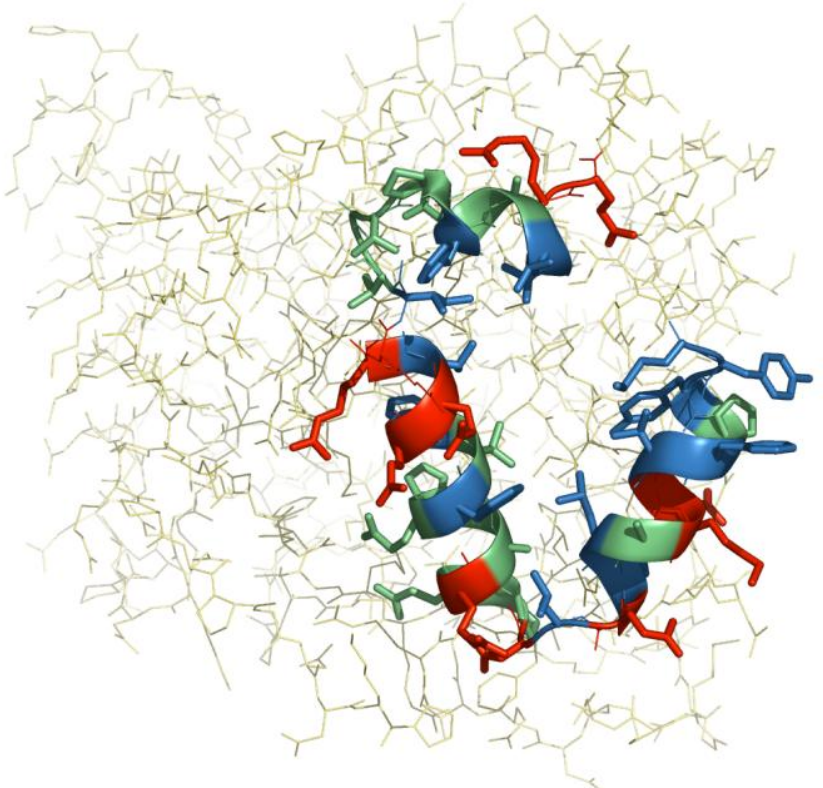

Figura 9 - Destaque do domínio N-terminal de EcDHODH. Uma visão frontal do N-terminal de EcDHODH, onde os resíduos hidrofóbicos estão destacados em azul e resíduos hidrofílicos carregados e não carregados estão coloridos em vermelho e verde, respectivamente. As cadeias laterais dos aminoácidos hidrofóbicos e carregados estão mostradas na figura. A figura foi preparada no programa Pymol [57].

Embora EcDHODH e HsDHODH sejam ambas pertencentes à classe 2 das DHODHs, nenhum inibidor da enzima humana foi eficaz na inibição da EcDHODH. Essa diferença é atribuída à grande variação na seqüência de aminoácidos no domínio $\mathrm{N}$-terminal das duas enzimas [58]. Além disso, há varias outras diferenças locais na estrutura dessas enzimas que podem explicar o porquê de os inibidores agirem de forma diferente nas duas enzimas. Dos nove resíduos envolvidos na ligação dos inibidores na HsDHODH, somente quatro são conservados em EcDHODH: His19, Arg102, Tyr318 e Pro326 (Figura 10), sendo que só a His19 está localizada no N-terminal. Estas análises reforçam a idéia de que o conhecimento detalhado das estruturas de DHODH de diversos organismos permite 0 planejamento de inibidores que interfiram seletivamente na atividade de $\mathrm{DHODH}$, retardando 
o crescimento e a proliferação de alguns organismos sem interferir no crescimento de outros (hospedeiros ou tecidos) [33].

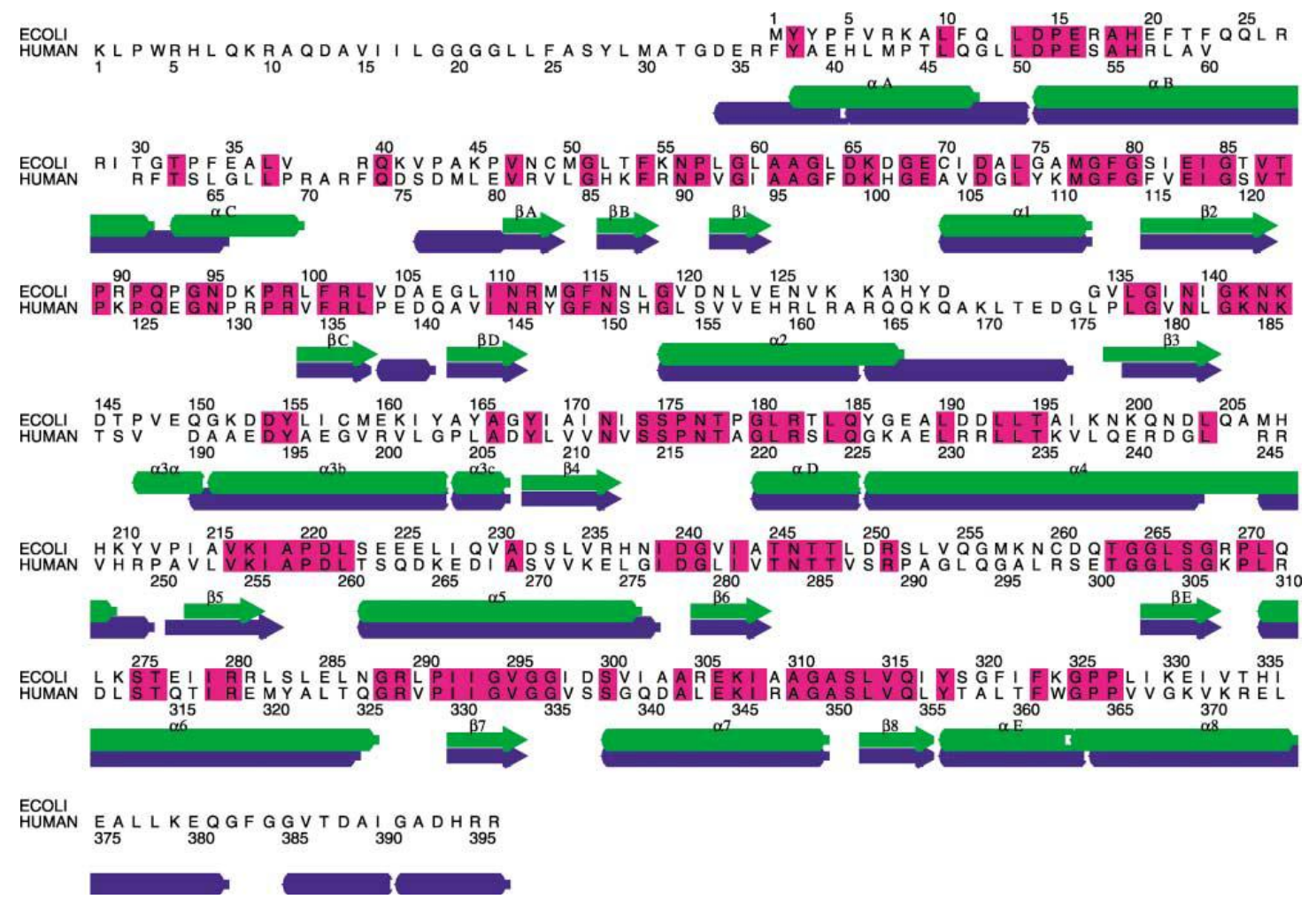

Figura 10 - Alinhamento seqüencial entre EcDHODH e HsDHODH. Os resíduos mostrados em rosa são conservados nas duas enzimas. Elementos de estrutura secundária são mostrados em verde $(\mathrm{EcDHODH})$ e azul $(\mathrm{HsDHODH})$. O símbolo a é usado tanto para $\alpha$-hélice quanto para hélice $3_{10}$. \{Fonte: Norager et al., 2005 [21]\}.

A Figura 11 mostra como o grupo $F M N$ e o produto da reação orotato são acomodados na molécula de EcDHODH. O anel de isoaloxasina do FMN é ligado na molécula de EcDHODH através de ligação de hidrogênio entre o grupo $\mathrm{NH}$ e a cadeia lateral da Thr86 e as cadeias laterais da Lys66 e Lys217 (Figura 11 A). A molécula de orotato é ligada ao sítio ativo via ligação de hidrogênio do seu grupo carboxílico com os grupos $\mathrm{NH}$ dos resíduos Gly114 e Phe115 e com as cadeias laterais da Lys66 e da Asn177. Sendo que as pontas hidrofílicas do anel (orotato) interagem com as cadeias laterais de Asn172, Asn111, Asn246, e Thr247 (Figura 11 B). 
A

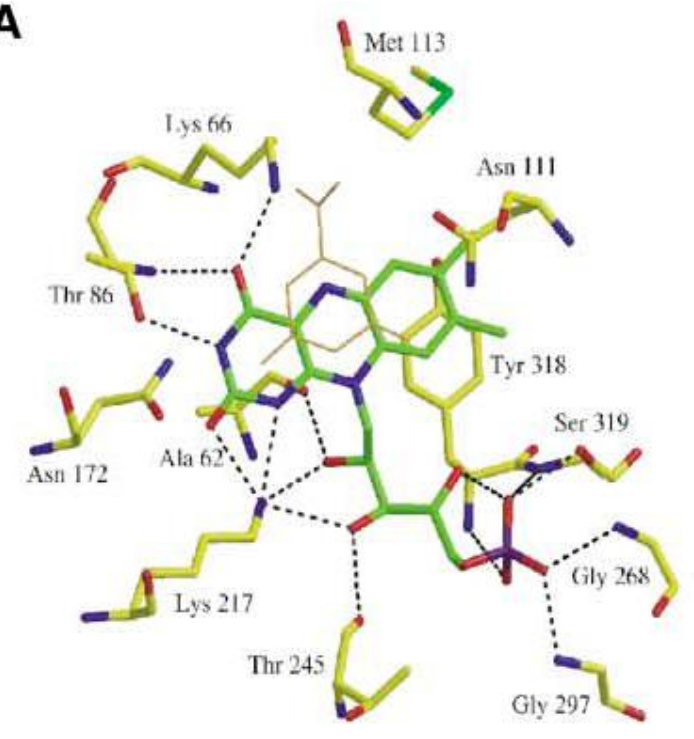

B

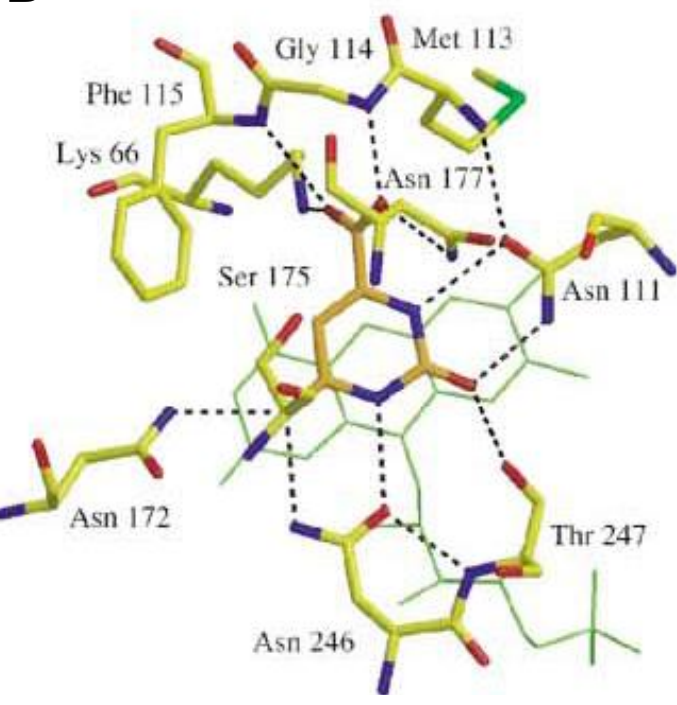

C

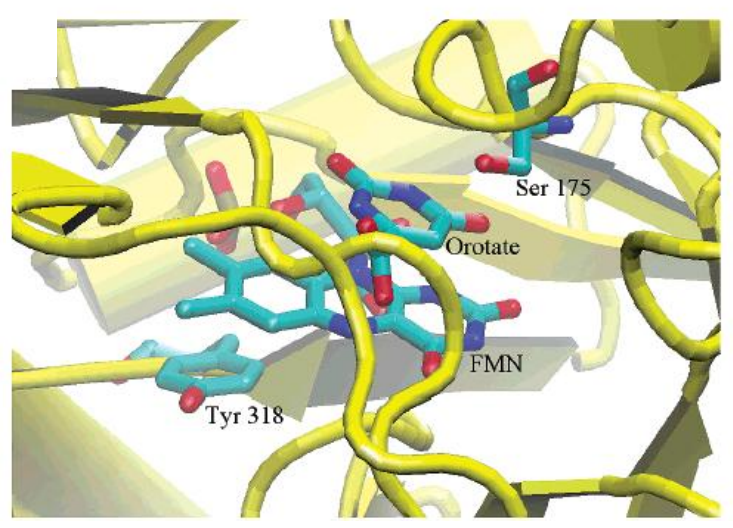

Figura 11 - Ambiente dos grupos FMN e orotato na molécula de EcDHODH. Em (A) e (B), as ligações de hidrogênio formadas entre o FMN ou orotato e a proteína estão mostradas em linhas pontilhadas. (A) FMN ligado EcDHODH, (B) orotato ligado a EcDHODH e (C) FMN e orotato ligados ao sítio ativo. Figura adaptada de: (A) e (B) Norager et al., 2002 [22] e (C) Shi et al., 2004 [59].

Recentemente, Shi et al. mostraram através da técnica "Single Molecule" que o estado de oligomerização e o enovelamento correto da EcDHODH recombinante são altamente dependentes da adição de detergentes à solução protéica [59]. Essa observação já havia sido feita em 1999 por Björnberg et al.. Eles utilizaram sedimentação por centrifugação em gradiente de sacarose e cromatografia de exclusão molecular para avaliar o estado de oligomerização da EcDHODH. Seus resultados revelaram que a proteína na ausência de detergente (Triton X-100 - neste caso) tende à formação de gigantescos agregados (da ordem de $530 \mathrm{kDa}$ ). Entretanto, na presença de Triton X-100 0,1\% (v/v) a 
massa molecular observada foi de aproximadamente $70 \mathrm{kDa}$, indicando que a EcDHODH pode ainda formar um dímero em solução [19]. Essas observações devem estar relacionadas ao alto caráter hidrofóbico da região $\mathrm{N}$-terminal da EcDHODH.

Com o intuito de investigar o papel estrutural da extensão N-terminal de EcDHODH, descrevemos neste capítulo os resultados obtidos a partir de análises por espectroscopia de RPE que podem sugerir uma explicação para o mecanismo de interação enzima-membrana.

\subsection{Metodologia}

\subsubsection{Expressão heteróloga - enzima EcDHODH}

O plasmídeo pAG1 contendo o gene que codifica a enzima EcDHODH bem como células de E. coli SO6645 e SO6740 utilizadas na expressão da EcDHODH nativa e mutante, respectivamente, nos foram gentilmente fornecidos pelo Dr. Kaj Frank Jensen do Departamento de Química Biológica do Instituto de Biologia Molecular da Universidade de Copenhagen.

Com o objetivo de expressar a enzima EcDHODH em bactéria, células de $E$. coli S06645 competentes preparadas pelo protocolo de cloreto de cálcio [60], foram transformadas com o plasmídeo pAG1, codificador da EcDHODH. Para a preparação do pré-inoculo, células já transformadas foram cultivadas $(250 \mathrm{rpm})$ a $37^{\circ} \mathrm{C}$ por aproximadamente 16h, em meio de cultura LB fresco sob agitação na presença de 100 $\mu \mathrm{g} / \mathrm{mL}$ de ampicilina. Depois de $16 \mathrm{~h}$, o pré-inóculo foi utilizado para inocular $250 \mathrm{~mL}$ de meio LB fresco contendo ampicilina (100 $\mu \mathrm{g} / \mathrm{mL})$, na proporção pré-inóculo:inóculo 1:100. As células foram mantidas sob agitação (250 rpm) a $37^{\circ} \mathrm{C}$ até que a densidade óptica (DO) a $600 \mathrm{~nm}$ atingisse valor entre 0,6-1,0, quando a expressão da proteína foi induzida pela adição de isopropil- $\beta$-D-tiogalactopiranosídeo $750 \mu \mathrm{M}$ (IPTG). A cultura foi, então, mantida sob agitação $(250 \mathrm{rpm})$ por $12 \mathrm{~h}$ a $37^{\circ} \mathrm{C}$. O material foi centrifugado a $15.000 \times \mathrm{g}, 4^{\circ} \mathrm{C}$, por 
30 minutos, e as células estocadas a $-20{ }^{\circ} \mathrm{C}$. A expressão da enzima foi monitorada por eletroforese em gel de poliacrilamida (SDS-PAGE).

\subsubsection{Extração da Enzima EcDHODH}

As células isoladas da cultura foram descongeladas e resuspensas em $10 \mathrm{~mL}$ de tampão de extração (fosfato de sódio $50 \mathrm{mM}, \mathrm{pH}$ 8,0, EDTA 0,25 mM). A seguir, o material foi sonicado em 12 ciclos de 30s interrompidos para resfriamento em banho de gelo por 1,5 min entre cada pulso. Após esta etapa, foi adicionado à solução $\mathrm{MgCl}_{2} 5 \mathrm{mM}$ e Triton $\mathrm{X}-100$ 0, $2 \%(\mathrm{v} / \mathrm{v})$. Em seguida, o extrato resultante foi centrifugado a $20.000 \times \mathrm{g}$ por 30 minutos para o isolamento das frações solúvel e insolúvel.

\subsubsection{Purificação da Enzima EcDHODH}

\subsubsection{Cromatografia de troca iônica}

O sobrenadante de cor amarelo resultante do rompimento das células foi submetido à cromatografia de troca iônica em coluna DEAE-Sepharose (24 $\mathrm{mL}$ ) previamente equilibrada com tampão de extração. A coluna foi, a seguir, lavada com $40 \mathrm{~mL}$ do tampão $A$ (fosfato de sódio $50 \mathrm{mM}$, pH 8,0, EDTA 0,1 mM e Triton X-100 0,1\% (v/v)). A enzima foi eluída da coluna através de um gradiente crescente de sal ( 0 a $1 \mathrm{M}$ de $\mathrm{NaCl}$ ) sob um fluxo de $1 \mathrm{~mL} / \mathrm{min}$. A eluição foi monitorada a $280 \mathrm{~nm}$ e frações de $5 \mathrm{~mL}$ foram coletadas. A eficiência da purificação foi avaliada através de eletroforese em gel de poliacrilamida. 


\subsubsection{Cromatografia por interação hidrofóbica}

Às frações provenientes da cromatografia de troca iônica $(\sim 15 \mathrm{~mL})$ que continham a proteína de interesse foi adicionado Triton x-100 0,5\% (v/v) e $\left(\mathrm{NH}_{4}\right)_{2} \mathrm{SO}_{4} 1,1 \mathrm{M}$ sólido. Após a precipitação dos contaminantes, a solução foi centrifugada por 60 min a 20.000 x g e a fração solúvel foi submetida à cromatografia por interação hidrofóbica através da coluna Phenyl-Sepharose $(2 \mathrm{~mL}$ ) previamente equilibrada em fosfato de sódio $50 \mathrm{mM}, \mathrm{pH} 7,0$, EDTA $0,1 \mathrm{mM}$ e $\left(\mathrm{NH}_{4}\right)_{2} \mathrm{SO}_{4}$ 1,1 M. A coluna foi lavada em um gradiente linear descendente de sulfato de amônio (1,1 M a 0 M) em tampão fosfato de sódio 50 mM, pH 7,0 e EDTA 0,1 $\mathrm{mM}$, sob um fluxo de $1 \mathrm{~mL} / \mathrm{min}$, durante 40 minutos. A enzima foi eluída da coluna em duas etapas: parte da enzima foi eluída durante o gradiente decrescente de sulfato de amônio e outra parte foi eluída na presença de $0,5 \%$ de Triton X-100 em tampão fosfato de sódio 50 mM, pH 7,0 e EDTA 0,1 mM. O grau de pureza das frações eluídas foi avaliado através de eletroforese, SDS-PAGE. A enzima livre de contaminantes foi concentrada por ultra filtração em sistema Milipore (NMWL: $10 \mathrm{kDa})$.

\subsubsection{Determinação da Concentração da Enzima}

A determinação da concentração da enzima EcDHODH foi realizada pelo método de Bradford [61], cuja reação colorimétrica envolve a oxidação dos aminoácidos aromáticos da proteína com o reagente Comassi Brilliant Blue G-250. Uma curva padrão foi preparada utilizando-se albumina do soro bovino (BSA), com concentrações variando de 0 a 0,2 $\mathrm{mg} / \mathrm{mL} .100 \mu \mathrm{L}$ da solução protéica diluída foi incubada por 10 minutos, em temperatura ambiente, com $1 \mathrm{~mL}$ de uma solução constituída de Comassi Brilliant Blue G-250 (0,1 $\mathrm{mg} / \mathrm{mL})$, etanol $5 \%(\mathrm{v} / \mathrm{v})$ e $10 \%(\mathrm{v} / \mathrm{v})$ de ácido orto-fosfórico $85 \%$. A leitura da absorção das amostras empregadas neste ensaio se deu em $590 \mathrm{~nm}$ e o ensaio foi realizado em triplicata para minimização de erros. 


\subsubsection{Ensaio da atividade enzimática}

O ensaio enzimático foi realizado em microcubeta (caminho ótico de $1 \mathrm{~cm}$ ) contendo $1 \mathrm{~mL}$ da solução: tris $100 \mathrm{mM}$, Triton X-100 0,1\% (v/v), pH 8,0, DCIP $50 \mu \mathrm{M}$, coenzima $\mathrm{Q}_{6}$ (quinona) $135 \mu \mathrm{M}$ e diidroorotato $500 \mu \mathrm{M}$. Após equilíbrio térmico da solução (a $25^{\circ} \mathrm{C}$ ), a reação foi iniciada pela adição da enzima $(5 \mu \mathrm{g})$ e a redução na absorbância do DCIP a 610 $\mathrm{nm}$ foi monitorada.

\subsubsection{Remoção do detergente}

Para a remoção do Triton $\mathrm{X}-100$, a amostra obtida a partir da cromatografia em coluna de interação hidrofóbica (aproximadamente $20 \mathrm{~mL}$ ), descrita anteriormente, foi incubada por $1 \mathrm{~h}$ a $4^{\circ} \mathrm{C}$ sob agitação suave com $5 \mathrm{~mL}$ da resina calbiosorb adsorvente (biobeads), previamente equilibrada em tampão fosfato de sódio $50 \mathrm{mM}, \mathrm{pH}$ 7,0, EDTA 0,1 $\mathrm{mM}$ e deaerada para eliminação de moléculas de oxigênio que podem bloquear os poros absorvedores de detergente. O tempo ótimo de incubação foi estabelecido monitorando-se a densidade ótica da solução a $280 \mathrm{~nm}$ a partir de alíquotas retiradas a cada cinco minutos de incubação. Esse procedimento foi repetido por uma hora até que a $\mathrm{DO}_{280}$, inicialmente maior que 2, fosse reduzida para um valor constante próximo a 0,2. A amostra resultante foi concentrada por ultra filtração em sistema Milipore (NMWL: $10 \mathrm{kDa})$

\subsubsection{Ressonância Paramagnética Eletrônica}

Alíquotas de soluções estoque dos lipídios DOPC ou DOPG em clorofórmio foram colocadas em tubos cônicos de vidro, juntamente com alíquotas de um dado marcador de spin. Estes envolveram moléculas de fosfolipídios com o grupo nitróxido em diferentes 
posições ao longo da cadeia carbônica dos fosfolipídios n-PC ( $n=5,10,12$ e 16) e também na cabeça polar (DPPTC). A massa final de lipídio por amostra foi de 0,2 mg e a concentração final de marcador de spin foi igual 0,5 mol\% do total de fosfolipídios. A mistura lipídio/marcador foi submetida a agitação por alguns segundos e secadas em fluxo de nitrogênio. Posteriormente, os filmes de lipídios/marcadores foram submetidos à centrifugação em um sistema Speedvac por 30 minutos para que traços de clorofórmio fossem totalmente removidos. Por fim, foi adicionado ao filme seco $60 \mu \mathrm{L}$ da solução contendo $178 \mu \mathrm{M}$ de EcDHODH em tampão fosfato de sódio 50 mM, pH 7,0, Triton X-100, assim perfazendo uma razão [lipídio]/[proteína] igual a 20. Para completa hidratação das vesículas, as amostras foram incubadas em sala escura à temperatura ambiente por 30 minutos. O volume final usado para as medidas de RPE foi de $100 \mu \mathrm{L}$. Os filmes preparados como controle foram resuspensos em $100 \mu \mathrm{L}$ de tampão fosfato de sódio $50 \mathrm{mM}, \mathrm{pH} 7,0$, Triton X-100.

É bem conhecido que a mistura de surfactantes a fosfolipídios leva a alterações na estrutura da membrana, as quais dependem basicamente da razão surfactante/fosfolipídio $[62,63]$. O contínuo aumento nesta razão é acompanhando pela transição da bicamada para monocamada. A concentração exata de Triton X-100 presente em nossa amostra é muito difícil de ser determinado, por esta razão vários ensaios com diferentes concentrações do detergente foram realizados para assegurar que a quantidade de detergente presente na amostra final fosse a mínima necessária para a solubilização da enzima. A concentração final de Triton X-100 usada neste trabalho foi acima da sua concentração micelar critica (cmc) e a razão detergente/fosfolipídio foi estimada como 1, o que resulta em uma mistura micelas mistas e vesículas mistas, como descrito por López et al. para um sistema constituído de Triton X-100 e fosfatidilcolina [62].

As amostras foram colocadas em cela chata de quartzo e as medidas de RPE foram realizadas à temperatura ambiente no espectrômetro Varian E109 funcionando em modo de onda contínua e equipado com ponte de microondas em banda X (9,5 GHz). As condições 
de medida foram: modulação $100 \mathrm{kHz}$, amplitude de modulação 1,0 G; potência $40 \mathrm{~mW}$ e varredura $100 \mathrm{G}$.

Monitoramento das alterações em função da temperatura no espectro do marcador de spin 5-PC em vesículas lipídicas de DMPC/Triton X-100 na ausência e presença da enzima EcDHODH foi feito também no espectrômetro Varian E109 descrito acima. O controle de temperatura foi feito com o controlador Varian (VT Controler E257-X). As amostras (DMPC/Triton X-100 e DMPC/Triton X-100/EcDHODH) preparadas como descrito na seção anterior para os fosfolipídios DOPC e DOPG foram colocadas em cela chata de quartzo de $50 \mu \mathrm{L}$ para que os espectros fossem tomados. A temperatura $\left(10\right.$ a $60{ }^{\circ} \mathrm{C}$ ) foi medida com termopar em intervalos de $5^{\circ} \mathrm{C}$. O fosfolipídio DMPC foi usado nestes experimentos por ter a temperatura de transição gel-fluído em torno de $24{ }^{\circ} \mathrm{C}$, o que possibilita o acompanhamento de possíveis mudanças nos espectros através de experimentos em torno da temperatura ambiente.

\subsubsection{Mutações sítio dirigidas na região $\mathrm{N}$-terminal da enzima EcDHODH}

Para a aplicação da técnica SDSL $[55,64]$ foram introduzidas oito mutações na região N-terminal da enzima EcDHODH, onde resíduos de interesse foram substituídos por resíduos de cisteína. A região $\mathrm{N}$-terminal corresponde a região da proteína supostamente envolvida na interação da EcDHODH com a membrana celular.

As mutações sítio dirigidas foram introduzidas na seqüência de nucleotídeos que codifica a EcDHODH através da utilização de oligonucleotídeos planejados especificamente para alterar a seqüência de códons que codificam os resíduos de interesse (Tabela 2 e 3). 
Tabela 2- Coordenadas dos resíduos de aminoácidos de EcDHODH que foram mutados para resíduos de cisteínas.

\begin{tabular}{l|lcc}
\hline Mutação & Resíduo de aminoácido & Posição & Nome do mutante \\
\hline 1 & Tirosina ( Tyr) & 2 & Y2C \\
2 & Phenylalanina (Phe) & 5 & F5C \\
3 & Lisina (Lys) & 8 & K8C \\
4 & Phenylanina (Phe) & 11 & F11C \\
5 & Histidina (His) & 19 & H19C \\
6 & Phenylanina (Phe) & 21 & F21C \\
7 & Phenylanina (Phe) & 23 & F23C \\
8 & Glutamina (Gln) & 25 & Q25C \\
\hline
\end{tabular}

Para gerar as mutações, 17 oligonucleotídeos específicos foram sintetizados baseados na construção de EcDHODH em pAG1 (Figura 12). Dois deles anelam em regiões específicas do plasmídeo que contêm sítios para endonucleases e os demais anelam internamente na seqüência de EcDHODH (Tabela 3):

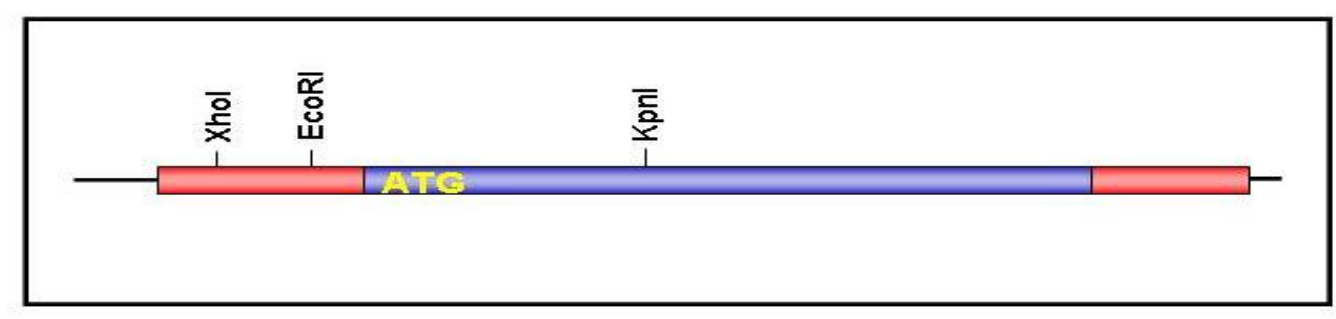

Figura 12 - Esquema ilustrativo do gene pyrD em pAG1. Vermelho corresponde à seqüência do plasmídeo pAG1; azul, região codificadora de $\mathrm{EcDHODH}$, destacado em amarelo o códon de início ATG. Xhol, EcoRl correspondem aos sítios para duas enzimas de restrição presentes em pAG1. $K p n l$, sítio de enzima de restrição presente na posição 253 da seqüência do gene pyrD.

Para a introdução dos aminoácidos de cisteína necessários para a realização dos estudos de RPE foram utilizadas duas diferentes estratégias. Para os aminoácidos localizados na extremidade da região N-terminal da proteína, Tyr2 ou Phe5, foram utilizados os oligonucleotídeos DHOC1-For e DHOC1-For que possuem o sítio para EcoRI e as mutações de interesse, e DHO-Kpn-ver que possui o sítio de restrição para a enzima Kpnl localizada na região correspondente ao aminoácido 253 da seqüência de EcDHODH. Os 
fragmentos amplificados de aproximadamente $280 \mathrm{pb}$ foram inseridos em um plasmídeo de propagação, pTZ57R/T (Fermentas) e submetidos à seqüenciamento para confirmação das mutações.

Tabela 3 - Oligonucleotídeos sintetizados para criar as mutações em EcDHODH.

\begin{tabular}{|c|c|c|}
\hline Oligonucleotídeo & Seqüência & Mutação \\
\hline DHO-Xho-For & ACTCGAGAAAATTTATCAAAAAG & - \\
\hline DHO-Eco-for & AGAATTCCAGGAGAGTTCATG & - \\
\hline DHO-260-Kpn-rev & ACGGTACCGATCTCGATCGATCC & - \\
\hline DHOC1-For & GAATTCCAGGAGAGTTCATGTGCTACCCCTTCGTTCGTAAAGC & $\mathrm{Y} 2 \mathrm{C}$ \\
\hline DHOC2-For & GAATTCCAGGAGAGTTCATGTACTACCCCTGCGTTCGTAAAGCC & $\mathrm{F} 5 \mathrm{C}$ \\
\hline DHOC3-For & TCGTTCGTTGTGCCCTTTTCCAGCTCGATCC & $\mathrm{K} 8 \mathrm{C}$ \\
\hline DHOC3-rev & GAAAAGGGCACAACGAACGAAGGGGTAGTACATG & $\mathrm{K} 8 \mathrm{C}$ \\
\hline DHOC4-For & GCCCTTTGCCAGCTCGATCCAGAGCGCGC & $\mathrm{F} 11 \mathrm{C}$ \\
\hline DHOC4-Rev & TCGAGCTGGCAAAGGGCTTTACGAACGAAGG & F11C \\
\hline DHOC5-For & GCGCGCTTGTGAGTTTACTTTTCAGCAATTAC & $\mathrm{H} 19 \mathrm{C}$ \\
\hline DHOC5-Rev & GTAAACTCACAAGCGCGCTCTGGATCGAGCTG & H19C \\
\hline DHOC6-For & TCATGAGTGTACTTTTCAGCAATTACGCCG & F21C \\
\hline DHOC6-rev & GAAAAGTACACTCATGAGCGCGCTCTGGATCG & F21C \\
\hline DHOC7-For & GTTTACTTGTCAGCAATTACGCCGTATTAC & F23C \\
\hline DHOC7-rev & AATTGCTGACAAGTAAACTCATGAGCGCGCTCTG & F23C \\
\hline DHOC8-For & CTTTTCAGTGCTTACGCCGTATTACAGGAACG & Q25C \\
\hline DHOC8-rev & CGGCGTAAGCACTGAAAAGTAAACTCATGAGC & Q25C \\
\hline
\end{tabular}

"Os códons codificadores do aminoácido císteina estão marcados em verde na seqüência dos oligonucleotídeos. 




Figura 13 - Esquema ilustrativo da primeira etapa de clonagem dos mutantes Y2C e F5C. Vermelho corresponde à seqüência do plasmídeo pAG1; azul escuro, seqüência codificadora de EcDHODH. EcoRl e Kpnl correspondem aos sítios para duas enzimas de restrição presentes em pAG1 e na posição 253 da seqüência de pyrD, respectivamente. Amarelo escuro corresponde ao códon mutado e azul claro representa à seqüência do vetor pTZ57R/T.

A segunda etapa da estratégia de clonagem dos mutantes corresponde à inserção do fragmento amplificado contendo a mutação de interesse no vetor de expressão pAG1. Para tanto, ambos pAG1 e pTZ57R/T foram submetidos a digestão pelas endonucleases EcoRl e Kpnl (Figura 14). O fragmento de aproximadamente 280 pb contendo a mutação de interesse, resultante da digestão do vetor de propagação pTZ57R/T, foi inserido no vetor de expressão. 
pAG1

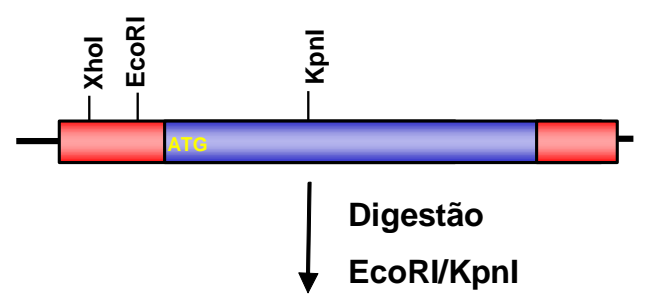

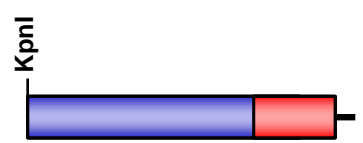

pAG1-MUTADO

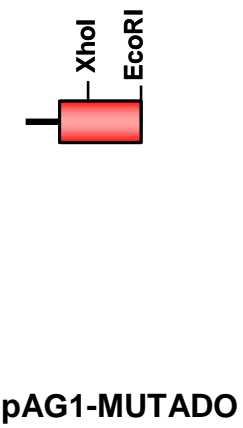

Clone I
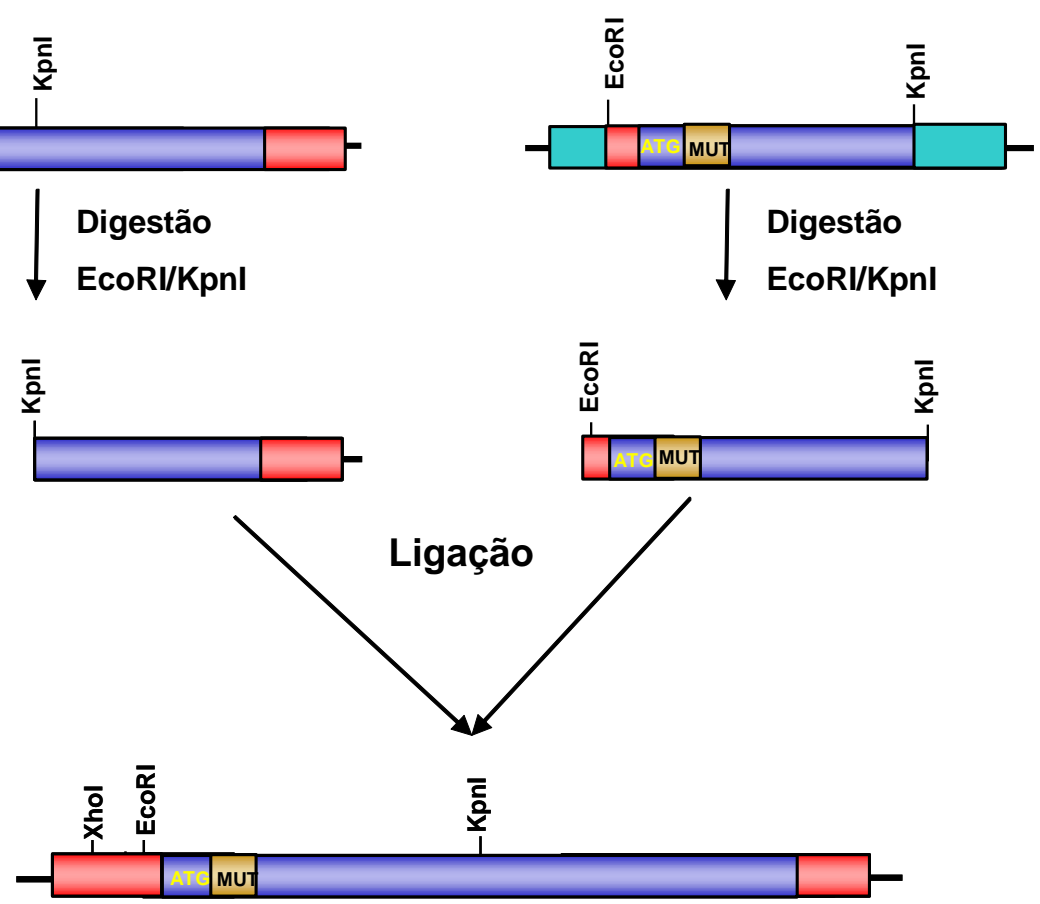

Figura 14 - Esquema ilustrativo da segunda etapa da clonagem dos mutantes Y2C e F5C. Vermelho representa a seqüência de nucleotídeos do plasmídeo pAG1; azul escuro, a seqüência de nucleotídeos codificadora de EcDHODH. Xhol e EcoRl correspondem aos sítios para duas enzimas de restrição presentes em pAG1. Kpnl, sítio de enzima de restrição presente na posição 253 da seqüência de pyrD. Azul claro representa à seqüência do vetor $\mathrm{pTZ57R/T}$ e amarelo escuro corresponde ao códon mutado. O códon de início ATG está destacado na figura em amarelo claro.

Para a clonagem dos mutantes K8C, F11C, H19C, F21C, F23C e Q25C foi utilizada uma segunda estratégia onde duas reações de PCR distintas foram realizadas utilizando diferentes conjuntos de oligonucleotídeos (Figura 15). Os produtos das reações, dois fragmentos de tamanhos distintos, foram usados como molde para uma terceira reação gerando um produto de aproximadamente 280 pb. Este fragmento que contém a mutação de interesse foi então inserido no plasmídeo de propagação pTZ57R/T.

A inserção do inserto no vetor de expressão pAG1 foi realizada de maneira similar à representada na Figura 14. 


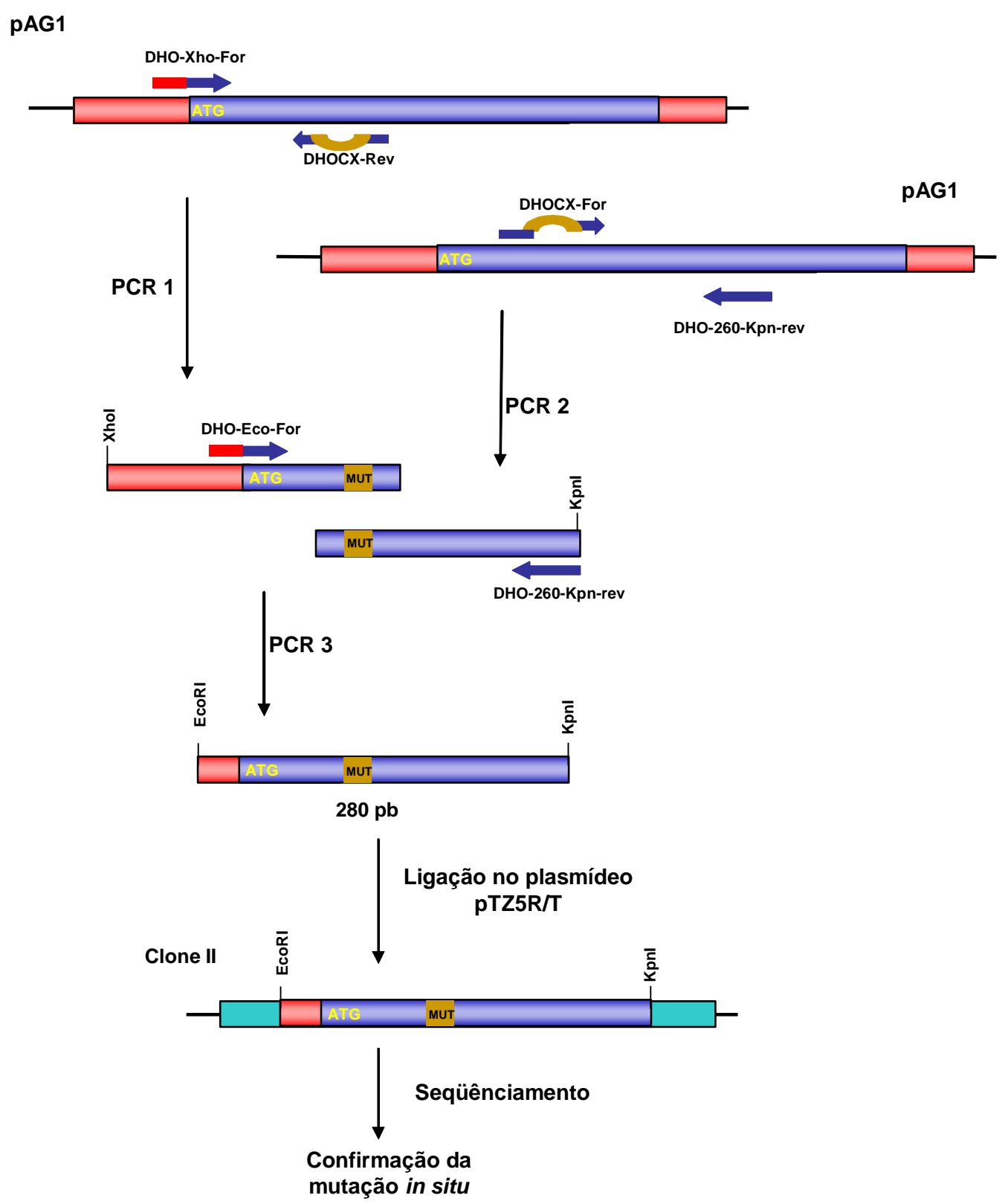

Figura 15 - Estratégia da primeira etapa da clonagem de EcDHODH mutada em K8, F11, H19, F21, F23 e Q25. A letra X em DHOCX-For ou em DHOCX-Rev, corresponde aos números de 3 a 8 , de acordo com a mutação a ser gerada (Tabela 2). Em vermelho está representada a seqüência de nucleotídeos do plasmídeo pAG1; em azul escuro, a seqüência de nucleotídeos codificadora de EcDHODH. Xhol, EcoRl e Kpnl correspondem a sítios para as enzimas de restrição de mesmos nomes presentes em pAG1 e pyrD. Em azul claro está representada à seqüência do vetor pTZ57R/T e em amarelo escuro o códon mutado. O códon de início ATG está destacado em amarelo claro. 


\subsubsection{Clonagem no Vetor PTZ57R/T}

Nas reações de PCR 1 e 2 (Tabela 3) foram utilizados 5 ng dos DNAs molde ( construção em pAG1), 2 pmol de cada oligonucleotídeo, dNTP's 0,2 mM, $\mathrm{MgCl}_{2} 1 \mathrm{mM}, 1,25$ unidades da enzima Taq High Fidelity , $5 \mu \mathrm{L}$ de 10 X High Fidelity PCR Buffer e 38,75 $\mu \mathrm{L}$ de $\mathrm{H}_{2} \mathrm{O}$, para um volume final de $50 \mu \mathrm{L}$. As condições de reação adotadas foram: 2 minutos a $94{ }^{\circ} \mathrm{C}$, seguido de 25 ciclos $\left(30\right.$ segundos a $94{ }^{\circ} \mathrm{C}, 20$ segundos a TM ${ }^{\circ} \mathrm{C}, \quad 20$ segundos a $72{ }^{\circ} \mathrm{C}$ ) e 5 minutos a $72{ }^{\circ} \mathrm{C}$, onde TM corresponde as temperaturas de anelamentos (TM) para cada par de oligonucleotídeo (Tabela 4). Os pares de oligonucleotídeos, as mutações a serem geradas e o tamanho dos fragmentos estão descritas na Tabela 4. As reações procederam em termociclador.

Os fragmentos amplificados foram separados por eletroforese em gel de agarose $1 \%$, contendo brometo de etídeo $0,1 \mu \mathrm{g} / \mathrm{mL}$. Em seguida, os fragmentos de DNA de interesse foram purificados, utilizando-se o "Kit Wizard SV Gel and PCR Clean - Up System", conforme recomendações do fabricante.

Após purificação os fragmentos amplificados foram aplicados novamente em gel de agarose $1 \%$ para quantificação. A quantidade de DNA obtida variou entre 50 e $100 \mathrm{ng} / \mu \mathrm{L}$ e o número de pares de base de cada fragmento se mostrou dentro do esperado. 
Tabela 4: Oligonucleotídeos utilizados nas reações de PCR para obtenção dos mutantes de EcDHODH.

\begin{tabular}{|c|c|c|c|c|c|}
\hline \multicolumn{2}{|c|}{ MUTAÇÃO } & \multirow{2}{*}{$\begin{array}{c}\text { "PRIMER } \\
\text { FORWORD” }\end{array}$} & \multirow{2}{*}{$\begin{array}{c}\text { "PRIMER } \\
\text { REVERSE" }\end{array}$} & \multirow{2}{*}{$\begin{array}{l}\mathrm{TM} \\
\left({ }^{\circ} \mathrm{C}\right)\end{array}$} & \multirow{2}{*}{$\begin{array}{c}\text { TAMANHO } \\
\text { DO } \\
\text { FRAGMENTO }\end{array}$} \\
\hline & & & & & \\
\hline $\mathrm{Y} 2 \mathrm{C}$ & PCR & $\mathrm{DHO}-\mathrm{C1}$ & DHO-260-Kpn & 55 & $277 \mathrm{pb}$ \\
\hline \multirow[t]{2}{*}{$\mathrm{F} 5 \mathrm{C}$} & PCR & DHO-C2 & DHO-260-Kpn & 55 & $277 \mathrm{pb}$ \\
\hline & PCR 1 & DHO-Xho & DHO-C3 & 55 & $140 \mathrm{pb}$ \\
\hline \multirow[t]{3}{*}{$\mathrm{K} 8 \mathrm{C}$} & PCR 2 & DHO-C3 & DHO-260-Kpn & 50 & $247 \mathrm{pb}$ \\
\hline & PCR3 & DHO-Eco-for & DHO-260-Kpn & 55 & $278 \mathrm{pb}$ \\
\hline & PCR 1 & DHO-Xho & DHO-C4 & 55 & $148 \mathrm{pb}$ \\
\hline \multirow[t]{3}{*}{$\mathrm{F} 11 \mathrm{C}$} & PCR 2 & $\mathrm{DHO}-\mathrm{C} 4$ & DHO-260-Kpn & 50 & $236 \mathrm{pb}$ \\
\hline & PCR3 & DHO-Eco-for & DHO-260-Kpn & 55 & $278 \mathrm{pb}$ \\
\hline & PCR 1 & DHO-Xho & DHO-C5 & 55 & $169 \mathrm{pb}$ \\
\hline \multirow[t]{3}{*}{$\mathrm{H} 19 \mathrm{C}$} & PCR 2 & DHO-C5 & DHO-260-Kpn & 50 & $213 \mathrm{pb}$ \\
\hline & PCR3 & DHO-Eco-for & DHO-260-Kpn & 55 & $278 \mathrm{pb}$ \\
\hline & PCR 1 & DHO-Xho & DHO-C6 & 55 & $174 \mathrm{pb}$ \\
\hline \multirow[t]{3}{*}{$\mathrm{F} 21 \mathrm{C}$} & PCR 2 & DHO-C6 & DHO-260-Kpn & 50 & $207 \mathrm{pb}$ \\
\hline & PCR3 & DHO-Eco-for & DHO-260-Kpn & 55 & $278 \mathrm{pb}$ \\
\hline & PCR 1 & DHO-Xho & $\mathrm{DHO}-\mathrm{C} 7$ & 55 & $181 \mathrm{pb}$ \\
\hline \multirow[t]{3}{*}{$\mathrm{F} 23 \mathrm{C}$} & PCR 2 & $\mathrm{DHO}-\mathrm{C7}$ & DHO-260-Kpn & 50 & $201 \mathrm{pb}$ \\
\hline & PCR3 & DHO-Eco-for & DHO-260-Kpn & 55 & $278 \mathrm{pb}$ \\
\hline & PCR 1 & DHO-Xho & $\mathrm{DHO}-\mathrm{C} 8$ & 55 & $187 \mathrm{pb}$ \\
\hline \multirow[t]{2}{*}{ Q25C } & PCR 2 & DHO-C8 & DHO-260-Kpn & 50 & $196 \mathrm{pb}$ \\
\hline & PCR3 & DHO-Eco-for & DHO-260-Kpn & 55 & $278 \mathrm{pb}$ \\
\hline
\end{tabular}

Os produtos obtidos das reações de PCR1 e PCR2 (Tabela 3) foram usados como molde em uma nova reação, PCR3. Foi adicionado ao DNA molde os reagentes necessários para a reação como descrito na seção anterior, exceto os "primers". As condições de reação 
adotadas foram: 2 minutos a $94{ }^{\circ} \mathrm{C}$, seguido de 5 ciclos $\left(30\right.$ segundos a $94{ }^{\circ} \mathrm{C}, 20$ segundos a $50{ }^{\circ} \mathrm{C}$ e 20 segundos a $72{ }^{\circ} \mathrm{C}$ ). A reação foi paralisada e 2 pmol dos oligonucleotídeos DHO-Eco-For e DHO-260-Kpn-Rev foram adicionados. A mistura de reação novamente levada ao termociclador para 25 ciclos (30 segundos a $94{ }^{\circ} \mathrm{C}, 20$ segundos a $55^{\circ} \mathrm{C}, 20$ segundos a $72^{\circ} \mathrm{C}$ ) seguido de 5 minutos a $72{ }^{\circ} \mathrm{C}$. O número de pares de bases esperado após amplificação ( 280 pb) foi verificado através de aplicação das amostras em gel de agarose $1 \%(\mathrm{~m} / \mathrm{v})$.

Os fragmentos amplificados nesta etapa foram purificados, utilizando-se o "Kit Wizard $^{\circledR}$ SV Gel and PCR Clean - Up System”.

Ao final da etapa anterior os produtos de PCR que geraram os mutantes $\mathrm{Y} 2 \mathrm{C}, \mathrm{F} 5 \mathrm{C}$ K8C, F11C, H19C, F21C, F23C e Q25C foram inseridos por reação de ligação no plasmídeo pTZ57R/T. A reação de ligação dos fragmentos de DNA ao vetor de clonagem foi conduzida de acordo com técnicas padrão de clonagem molecular em plasmídeos [65]. O fragmento de DNA a ser clonado e o vetor foram utilizados na razão molar entre 1:1,5, em um volume final de $10 \mu \mathrm{L}$, na presença da enzima $\mathrm{T}_{4}$ DNA Ligase, em Tris- $\mathrm{HCl} 30 \mathrm{mMol} / \mathrm{L}, \mathrm{pH} 7,8, \mathrm{MgCl}_{2} 10$ $\mathrm{mMol} / \mathrm{L}$, DTT $10 \mathrm{mMol} / \mathrm{L}, 1 \mathrm{mMol} / \mathrm{L}$ de ATP. A reação foi incubada a $22{ }^{\circ} \mathrm{C}$ por 1 hora.

Os produtos das reações de ligação vetor pTZ57R/T-fragmento mutado foram propagados na estirpe de E. coli DH5- $\alpha$.

Para transformação, foram adicionados $10 \mu \mathrm{L}$ da mistura de ligação a uma alíquota de $50 \mu \mathrm{L}$ de células competentes $\mathrm{DH} 5-\alpha$, e a suspensão foi mantida a $0{ }^{\circ} \mathrm{C}$ por 30 minutos. Após um choque térmico de 2 minutos a $42{ }^{\circ} \mathrm{C}$, foi adicionado $250 \mu \mathrm{L}$ de meio LB, seguido por incubação a $37^{\circ} \mathrm{C}$, por uma hora sob agitação de $150 \mathrm{rpm}$. As células foram espalhadas em placas contendo LB (sólido), ampicilina $100 \mu \mathrm{g} / \mathrm{mL}$, IPTG $500 \mu \mathrm{M}$ e X-Gal $100 \mathrm{mg} / \mathrm{mL}$, para seleção de colônias transformantes. 


\subsubsection{Isolamento do DNA plasmidial e Teste de Restrição}

Os isolamentos de DNAs plasmidiais foram conduzidos, em pequena escala, pelo método da lise alcalina e adsorção de DNA em colunas Wizard ${ }^{\circledR}$ SV Minicolunns, utilizando o "Wizard ${ }^{\circledR}$ Plus SV Minipreps DNA Purification System" (Promega).

O DNA plasmidial, isolado de bactérias transformadas, foi digerido com as enzimas de restrição $\mathrm{Kpnl}$ e $E c o R l$ e separados por eletroforese em gel de agarose $1 \%$ para identificação dos clones de interesse. As colônias recombinantes foram armazenadas em glicerol $30 \%$ a $-80{ }^{\circ} \mathrm{C}$ e os DNAs de interesse foram enviados para Laboratório de Biologia Molecular (LBM) do Laboratório Nacional de Luz Síncrotron (LNLS), em Campinas, para seqüenciamento.

As seqüências recebidas do LNLS foram analisadas a priori através do programa Gene Runner para identificação do frame de leitura correto e tradução de nucleotídeos para aminoácidos. Posteriormente, foram alinhadas com a seqüência nativa da EcDHODH no plasmídeo pAG1 através do programa Multalin (Multiple sequence alignment by Florence Corpet ) [66].

\subsubsection{Clonagem no vetor pAG1}

Uma vez identificados através do seqüenciamento os clones "positivos", ou seja, aqueles que contêm a mutação na posição esperada é preciso inserir tais insertos no vetor de expressão pAG1 para dar início à produção da proteína mutada.

O fragmento mutado foi digerido do vetor de clonagem PTYZ57R, em duas etapas. A principio a digestão de $34 \mathrm{ng}$ de DNA foi feita com $10 \mathrm{un} / \mu \mathrm{L}$ da enzima $\mathrm{Kpnl}$ em $4 \mu \mathrm{L}$ de React 4 (tampão da enzima $K p n l$ ), o volume final da reação foi de $40 \mu \mathrm{L}$, a mistura foi incubada a $37^{\circ} \mathrm{C}$ por 4 horas. A seguir a reação enzimática foi paralisada por incubação da 
mistura a $65{ }^{\circ} \mathrm{C}$ por 10 minutos. Posteriormente a mistura foi passada através de uma coluna G-25 (Amersham Bioscience) para a remoção do React 4. Posteriormente foi adicionado ao DNA (34 ng), $10 \mathrm{u} / \mu \mathrm{L}$ da enzima EcoRl e $5 \mu \mathrm{L}$ de React 3 (tampão da enzima EcoRI) e a mistura de reação foi incubada a $37^{\circ} \mathrm{C}$ "overnight".

Os fragmentos digeridos foram purificados do gel de agarose $1 \%$ como descrito em seções anteriores e uma alíquota foi reaplicada em gel de agarose $1 \%$ para quantificação.

O plasmídeo pAG1 também foi clivado com as mesmas enzimas (Kpnl e EcoRI) e transformado em células S06645. A reação de ligação dos fragmentos mutados ao vetor pAG1 foi feita incubando-se $15 \mathrm{ng}$ do vetor pAG1, $3 \mathrm{u} / \mu \mathrm{L}$ da enzima $T_{4} D N A$ ligase, tampão de $T_{4}$ DNA ligase [1x] e $7 \mathrm{ng}$ de inserto (MUT 1 a 8 ) a $4{ }^{\circ} \mathrm{C}$ por 16 horas. O volume final da reação foi de $10 \mu \mathrm{L}$.

As misturas de ligação foram transformadas em células SO6645. De cada placa resultante da transformação em células SO6645, foram pegas duas colônias isoladas e cada uma foi inoculada em $5 \mathrm{~mL}$ de meio LB contendo $100 \mathrm{ng} / \mu \mathrm{L}$ de ampicilina a $37{ }^{\circ} \mathrm{C}$ por 16 horas e os DNAs de interesse foram isolados através do Kit "Wizard ${ }^{\circledR}$ Plus SV Minipreps DNA Purification System" e uma alíquota dos DNAs extraídos foi enviada para seqüenciamento para confirmação da ligação correta do fragmento ao vetor pAG1.

O resultado do seqüenciamento foi analisado através dos softwares Gene Runner e Multalin.

\subsubsection{Mutações sítio dirigidas na região $\mathbf{N}$-terminal da enzima EcDHODH livre das cisteínas nativas}

Com o objetivo de estudar a interação da enzima EcDHODH através da técnica SDSL, foram também realizadas mutações na região $\mathrm{N}$-terminal para a enzima livre de aminoácidos nativos de cisteína. Para a realização destes estudos as quatro cisteínas nativas (C49, C70, C158 e C260) foram inicialmente mutadas por alaninas. Essas mutações foram feitas pela empresa Mutagenex - Inovative Mutagenesis Service (EUA) e o gene 
mutado religado no vetor pAG1. Para evitar confusões, a construção contendo o gene que codifica EcDHODH onde os códons que codificam cisteína foram substituídos por códons que codificam alanina será denominado de pAG1 $A$.

Os mutantes obtidos com o procedimento descrito na seção 4.1.8.3, foram digeridos com 20 U da enzima de restrição Xhol e 50 U da enzima de restrição Hpal. O sítio de restrição para a enzima $H p a l$ está localizado no gene pyrD antes do códon que codifica o primeiro resíduo de cisteína na seqüência de aminoácidos da EcDHODH, como ilustrado na Figura 16. A digestão foi realizada a $37^{\circ} \mathrm{C}$ durante 14 horas.

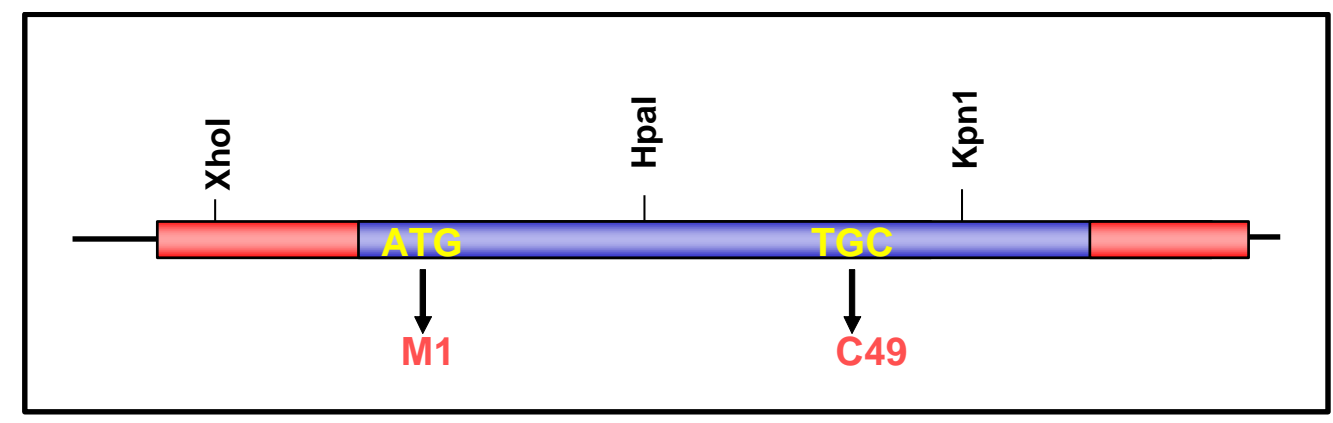

Figura 16 - Esquema ilustrativo do gene codificador da EcDHODH em pAG1. Vermelho corresponde à seqüência do plasmídeo pAG1; azul, seqüência codificadora de EcDHODH (gene pyrD), destacado em amarelo o códon de início ATG e o códon que codifica o primeiro resíduo de cisteína na seqüência da EcDHODH. Xhol corresponde ao sítio para a enzima de restrição de mesmo nome presente em pAG1. Hpal e Kpnl, sítios para as enzimas de restrição presente nas posições 144 e 253 da seqüência de $p y r D$, respectivamente.

Os fragmentos de DNA foram purificados com o kit "Wizard SV gel and pCR clen-up system", após eletroforese em gel de agarose 1\%. Os fragmentos foram inseridos no plasmídeo pAG1A previamente linearizado com as mesmas endonucleases, Figura 17. A proporção plasmídeo:fragmento utilizada na reação de ligase foi 1:4, juntamente com $2 \mu \mathrm{L}$ de tampão de ligação (10X) e $1 \mathrm{u} / \mu \mathrm{L}$ de $\mathrm{T}_{4}$ DNA ligase, a mistura foi incubada a $4{ }^{\circ} \mathrm{C}$ por 16 horas. As reações de ligação foram usadas para transformar a linhagem de E. coli, SO6740, e as possíveis colônias positivas foram selecionadas em meio de cultura LB contendo $50 \mu \mathrm{g} / \mathrm{mL}$ de ampicilina. Os clones positivos foram confirmados após extração do DNA plasmidial das colônias seguida de análise de restrição (com as enzimas supra citadas) 
e a seguir enviados para o Laboratório de Cristalografia de Proteínas do IFSC/USP para seqüenciamento.

Todo o procedimento de clonagem realizado neste trabalho foi conduzido de acordo com as técnicas padrão de clonagem molecular descritas por Sambrook et al. [65].

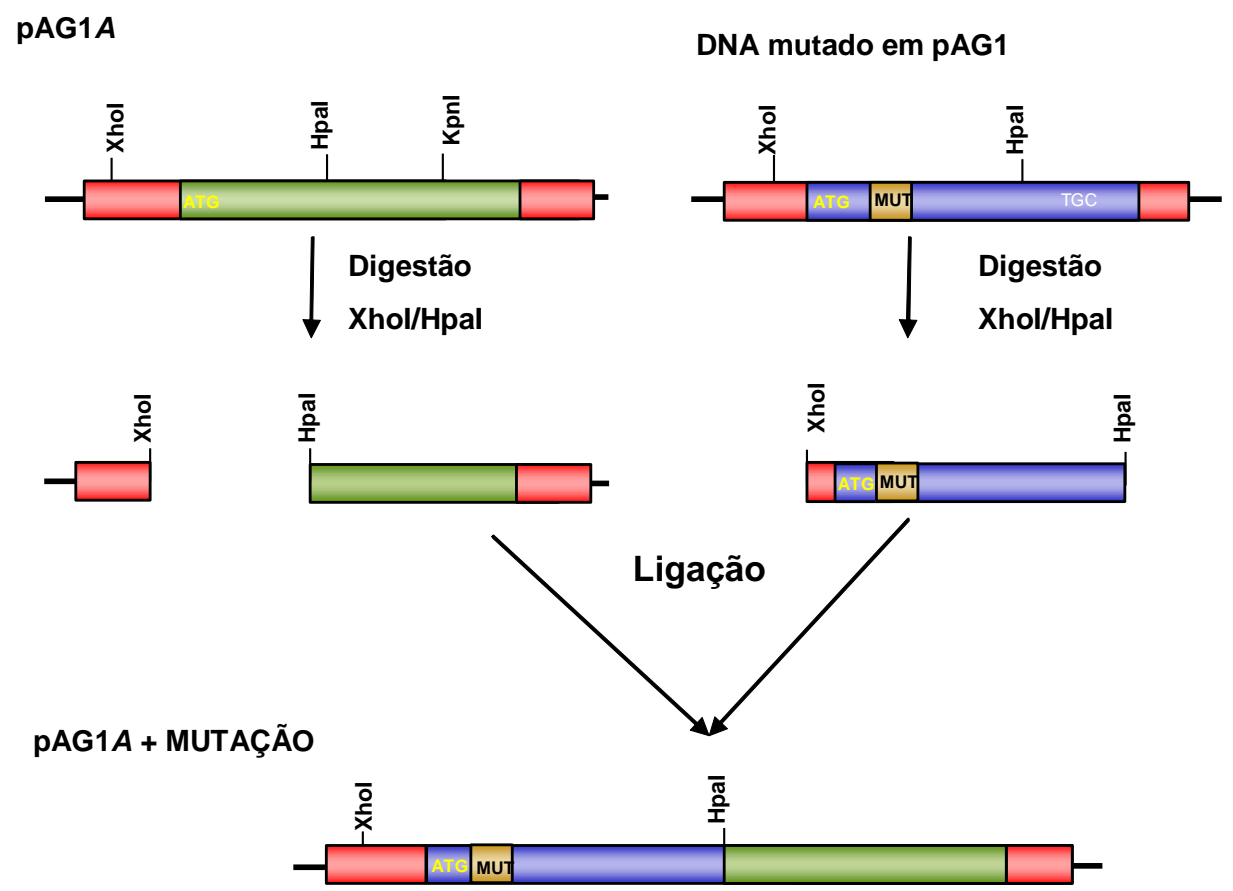

Figura 17 - Esquema ilustrativo da clivagem dos fragmentos mutados em pAG1 e ligação desses fragmentos em PAG1A. Vermelho representa à seqüência do plasmídeo pAG1; azul, representa a seqüência de nucleotídeos codificadora de $\mathrm{EcDHODH}$ e verde a seqüência codificadora de EcDHODH onde códons codificadores de cisteínas foram substituídos por códons codificadores de alaninas. Destacado em branco está o códon que codifica o primeiro resíduo de cisteína na seqüência da EcDHODH e a região em amarelo representa a mutação de interesse. Xhol corresponde ao sítio para a enzima de restrição de mesmo nome presente em pAG1. Hpal, sítio para a enzima de restrição presente na posição 144 da seqüência do gene codificador de EcDHODH.

\subsubsection{Expressão e purificação dos mutantes de EcDHODH}

O procedimento de expressão e purificação dos mutantes foi o mesmo adotado para a enzima livre de mutação (descrito nas seções 4.1.1 a 4.1.3), exceto pela utilização da linhagem SO6740 de E. coli para os experimentos de expressão. Esta cepa possui o gene 
pyrD deletado para evitar a contaminação dos mutantes com a proteína nativa expressa pela bactéria.

\subsubsection{Ressonância Paramagnética Eletrônica - Marcação de spin Sítio dirigida (SDSL)}

Alíquotas de $5 \mu \mathrm{L}$ da solução estoque do marcador de spin MTSL a $200 \mathrm{mM}$ em acetonitrila foram colocadas em tubos cônicos de vidro e secadas com nitrogênio a fim de promover a evaporação da acetonitrila. O filme de MTSL foi resuspenso em tampão fosfato de sódio $50 \mathrm{mM}$, pH 8,0, EDTA 0,1 mM, Triton X 100 0,1\% (v/v), agitado em vortex por alguns minutos e submetido a sonicação em sonicador de banho por 5 minutos para total solubilização do marcador de spin. A solução de MTSL e tampão foi adicionada à solução da EcDHODH nativa ou aos mutantes de EcDHODH obtidos como descrito na seção 4.1.9. A mistura proteína-MTSL foi mantida sob agitação suave, $4{ }^{\circ} \mathrm{C}$ durante a noite (aproximadamente $16 \mathrm{~h}$ ) a fim de maximizar a marcação.

Como o detergente Triton X-100 em altas concentrações pode interferir na interação marcador-proteína podendo diminuir a acessibilidade do marcador à cisteína livre, a marcação foi testada em diferentes etapas do processo de purificação dos mutantes de EcDHODH: 1) a marcação da EcDHODH mutante foi feita com a solução de proteína eluída da coluna DEAE Sepharose, sendo que após a marcação os demais passos cromatográficos foram mantidos para a obtenção de amostras homogêneas e livres de contaminantes, como descrito na seção 4.1.3.2; 2) a marcação da enzima EcDHODH mutante foi feita com a solução de proteína eluída durante a ultima etapa cromatográfica na coluna Phenyl Sepharose. A seguir a amostra foi concentrada e dialisada exaustivamente (a fim de promover a remoção das moléculas de marcador livres na solução) para a realização das medidas de RPE. No ultimo caso o tampão utilizado para resuspender o filme de MTSL foi fosfato de sódio 50 mM, pH 7,0, EDTA 0,1 mM, Triton X-100 0,5% (v/v). 
Após marcação as amostras foram incorporadas a vesículas de DOPC, como descrito na seção 4.1.7. As amostras foram colocadas em cela chata de quartzo (100 $\mu \mathrm{L})$ e as medidas de RPE foram realizadas à temperatura ambiente no espectrômetro Varian E109 descrito anteriormente. As condições de medida foram: modulação $100 \mathrm{kHz}$, amplitude de modulação 1,0 G; potência 20 mW e varredura 100 G. 


\subsection{Resultados e Discussões}

\subsubsection{Expressão heteróloga da EcDHODH}

Para realizarmos estudos espectroscópicos da interação EcDHODH-membrana fez se necessária a síntese da proteína diidroorotato desidrogenase de $E$. coli na forma recombinante. A enzima foi eficientemente produzida em bactéria sob as condições descritas na seção 4.1.1. A síntese da proteína recombinante foi conduzida em E. coli, estirpe SO6645. A indução da síntese da proteína de interesse é realizada de forma indireta, adicionando-se IPTG ao meio de cultura que age sobre o promotor $\mathrm{T} 7_{\mathrm{A} 1 / 04 / 03}$ o qual controla a expressão do gene de interesse, finalizando com a síntese da proteína exógena. Um excelente rendimento de $28 \mathrm{mg}$ de proteína por litro de cultura é alcançado quando a cultura de células para uma densidade ótica $\mathrm{DO}_{600}$ se encontre entre 0.7 a 1.0 [67] seja induzida com $750 \mu \mathrm{M}$ de IPTG.

A expressão da enzima foi monitorada por SDS-PAGE 15\%, Figura 18, onde pode se observar bandas de expressão adicionais frente ao conteúdo de proteínas totais de $E$. coli S06645. Nesta figura, pode-se observar uma banda de aproximadamente $37 \mathrm{kDa}$, que corresponde ao peso molecular da $\mathrm{ECDHODH}$, indicando que a enzima foi expressa com sucesso. 


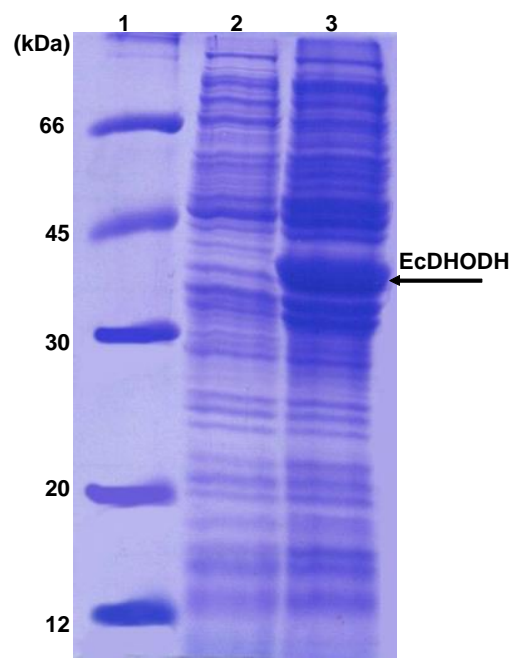

Figura 18 - Análise em gel de poliacrilamida das frações provenientes do teste de expressão da EcDHODH. As massas moleculares do marcador (coluna 1) são: 66 kDa, 45 kDa, 30 kDa, 20 kDa e $12 \mathrm{kDa}$, respectivamente. A coluna 2 refere-se à cultura antes da indução e a coluna 3 refere-se à cultura após $12 \mathrm{~h}$ de indução a $37^{\circ} \mathrm{C}$, com IPTG $750 \mu \mathrm{M}$. A massa molecular calculada para a enzima EcDHODH é de $37 \mathrm{kDa}$.

\subsubsection{Purificação da EcDHODH}

O procedimento inicial adotado para a purificação da enzima EcDHODH e que envolvia duas etapas cromatográficas foi o mesmo empregado por Björnberg et al. [19]. Todavia, o sucesso esperado não foi alcançado com este protocolo. É provável que questões como $\mathrm{opH}$ dos tampões utilizados nas diversas etapas de purificação está diretamente ligado a insucesso deste procedimento experimental. Em nossas análises, o ponto isoelétrico de EcDHODH foi estimado em 7.6. No entanto, os experimentos previamente propostos na literatura envolviam a utilização de cromatografia por troca aniônica em pH 7.0. Baseado no pl de 7.6, em pH 7.0, a proteína não estaria suficientemente carregada para interagir com a coluna de troca aniônica DEAE-Sepharose. Além disso, a concentração de detergente (Triton X-100) contido na amostra durante o procedimento de precipitação com $\left(\mathrm{NH}_{4}\right)_{2} \mathrm{SO}_{4}$ (segunda etapa de purificação descrita em [19]) parece não ser o suficiente para impedir a interação entre a EcDHODH com contaminantes presentes na amostra. Desta forma, tomando como base este raciocínio, 
alterações no protocolo de purificação da enzima foram introduzidas com sucesso, como descrito a seguir.

\subsubsection{Cromatografia de troca iônica}

A purificação de EcDHODH I se inicia com a utilização de cromatografia por troca aniônica fraca usando a resina DEAE-sepharose. A análise do perfil eletroforético permitiu localizar as frações contendo a EcDHODH, correspondente ao pico eluído no intervalo de 50 a $70 \%$ de sal, conforme indicado na Figura 19. A análise dos resultados (Figura 20) indica que esta etapa de purificação foi importante para retirar uma grande parte de contaminantes do material bruto, mas não foi suficientemente eficiente para purificar a proteína, exigindo a introdução de uma nova etapa cromatográfica.

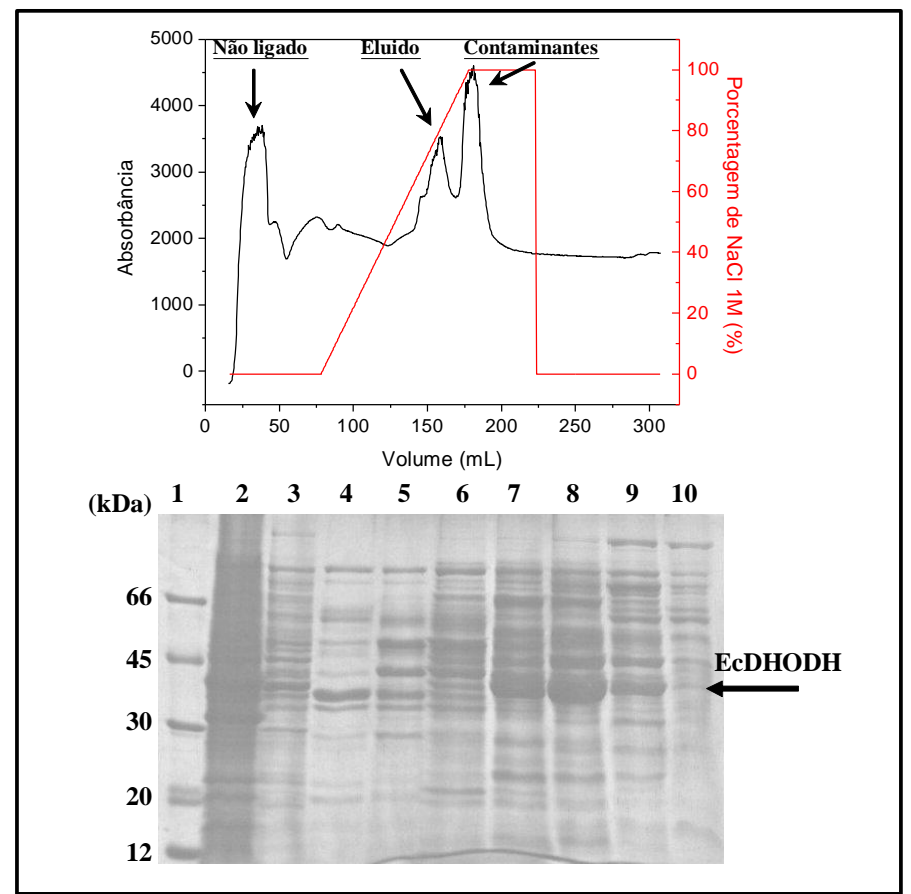

Figura 19 - Perfil de eluição da enzima EcDHODH a partir da coluna DEAE-Sepharose e análise por eletroforese em SDS-PAGE. Os picos indicados por setas no cromatograma correspondem às frações que contêm a enzima. A coluna 1 refere-se ao padrão de peso molecular. As colunas 2 e 3 referem-se à fração solúvel das células lisadas e o material que não se ligou à coluna, respectivamente. As colunas 4 a 10 referem-se às frações que compõem os demais picos no cromatograma. A proteína de interesse elui majoritariamente nas frações representadas nas colunas 7 a 9 equivalendo ao pico indicado no cromatograma. 


\subsubsection{Cromatografia de interação hidrofóbica}

O segundo passo cromatográfico empregado para a purificação de EcDHODH consiste na aplicação da cromatografia por interação hidrofóbica em coluna PhenylSepharose (Figura 21). Para tal, as frações correspondentes a eluição da EcDHODH a partir da primeira etapa de purificação foram inicialmente combinadas na presença de $0,5 \%$ de Triton X-100 (v/v). A adição do detergente tinha como objetivo minimizar a agregação da nossa proteína de interesse causada pela interação da região hidrofóbica localizada na região $\mathrm{N}$-terminal com regiões hidrofóbicas da mesma proteína ou proteínas contaminantes. $\mathrm{O}$ material foi então submetido à precipitação na presença de $1,1 \mathrm{M}$ de $\left(\mathrm{NH}_{4}\right)_{2} \mathrm{SO}_{4}$ para neutralizar as cargas da proteína antes da utilização da coluna hidrofóbica. A análise dos resultados mostra que a adição de $1,1 \mathrm{M}$ de $\left(\mathrm{NH}_{4}\right)_{2} \mathrm{SO}_{4}$ foi também útil para promover a precipitação de contaminantes. A enzima foi eluída sob um gradiente de Triton X-100 conforme apresentado na Figura 21.

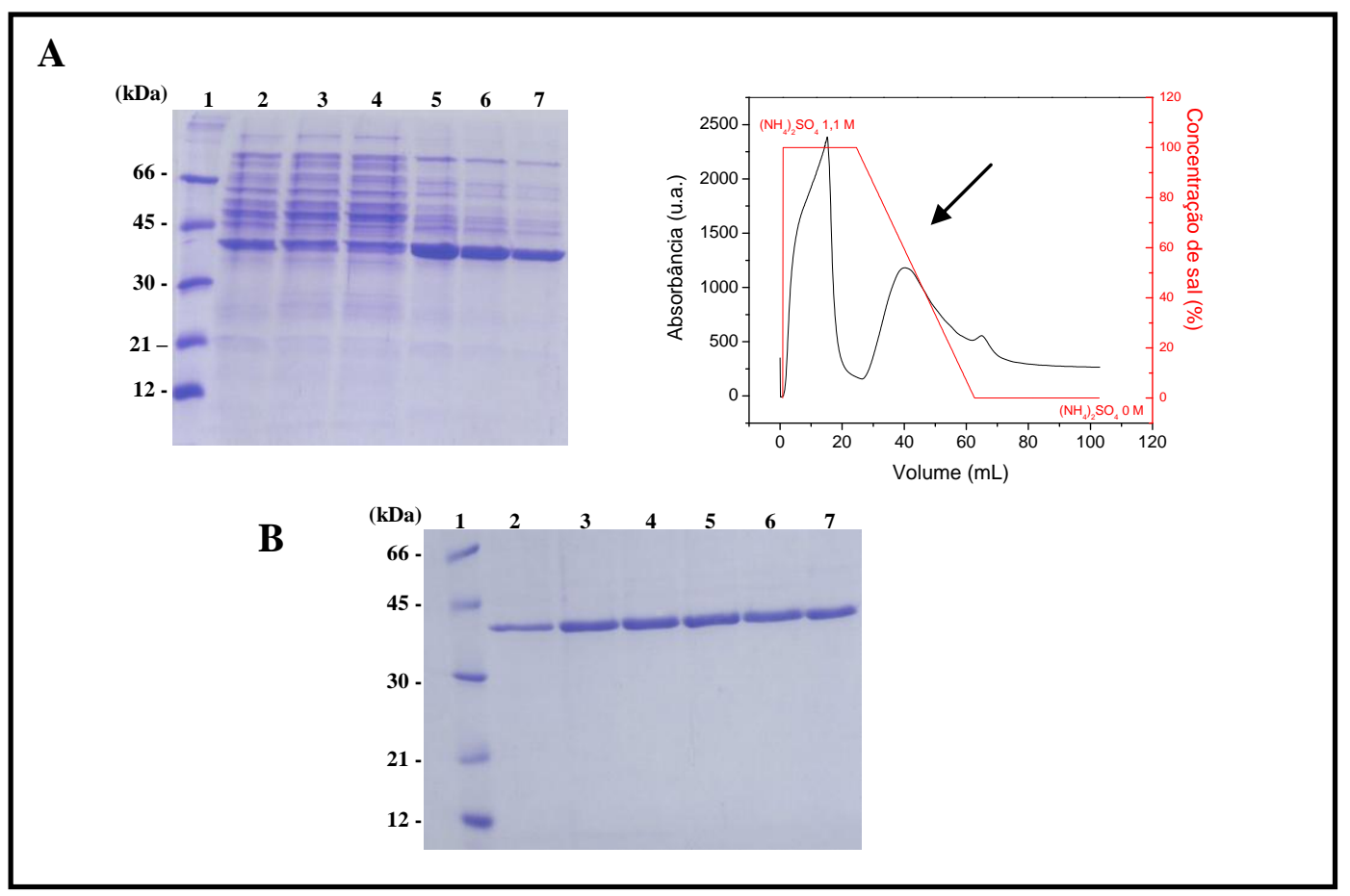

Figura 20 - Análise por eletroforese em SDS-PAGE da purificação de EcDHODH em coluna de interação hidrofóbica. (A) corresponde ao gel e cromatograma do gradiente decrescente de $\left(\mathrm{NH}_{4}\right)_{2} \mathrm{SO}_{4}$. (100\% de sal equivale a 1,1 $\left.\mathrm{M}\left(\mathrm{NH}_{4}\right)_{2} \mathrm{SO}_{4}\right)$. Os números no gel correspondem às frações que compõe o pico indicado pela seta no cromatograma. (B) SDS-Page das frações contendo a EcDHODH, eluidas com $0,5 \%$ de Triton X-100. 
A presença do detergente Triton X-100 durante as etapas de preparação da amostra de proteína EcDHODH é essencial para a solubilização da proteína e conseqüente sucesso dos experimentos de RPE. Como comentado na introdução deste capítulo, na ausência deste surfactante, o caráter altamente hidrofóbico apresentado pela região $\mathrm{N}$-terminal da enzima, leva à agregação das moléculas de proteína com subseqüente formação de oligômeros, sendo o grau de oligomerização dependente da concentração de detergente.

\subsubsection{Atividade enzimática}

Como discutido anteriormente, a enzima EcDHODH catalisa a única reação de oxiredução presente na biossíntese de novo de nucleotídeos de pirimidina, a conversão de diidroorotato $(\mathrm{DHO})$ em orotato. O ciclo catalítico desta enzima envolve duas etapas como mostrado na Figura 21. Na primeira parte da reação, o DHO é oxidado em orotato e o FMN é reduzido em $\mathrm{FMNH}_{2}$. Na segunda metade da reação, o $\mathrm{FMNH}_{2}$ é reoxidado com o auxílio de um aceptor de elétrons. Para membros da família 2 das $\mathrm{DHODH}$, o agente oxidante é a quinona que através da reoxidação do FMN permite que a enzima realize novos ciclos de catálise. O ensaio enzimático utilizado monitora a atividade da enzima de forma indireta através da utilização da molécula de DCIP (Figura 22), reduzindo a quinona. Este agente colorimétrico (DCIP) é comumente utilizado como o aceptor de elétrons final nos estudos enzimáticos de DHODHs, porque permite um ensaio fotométrico conveniente devido a sua absorção em $610 \mathrm{~nm}$ [68-70]. Quando o DCIP é reduzido ele perde a coloração azul passando a incolor. 


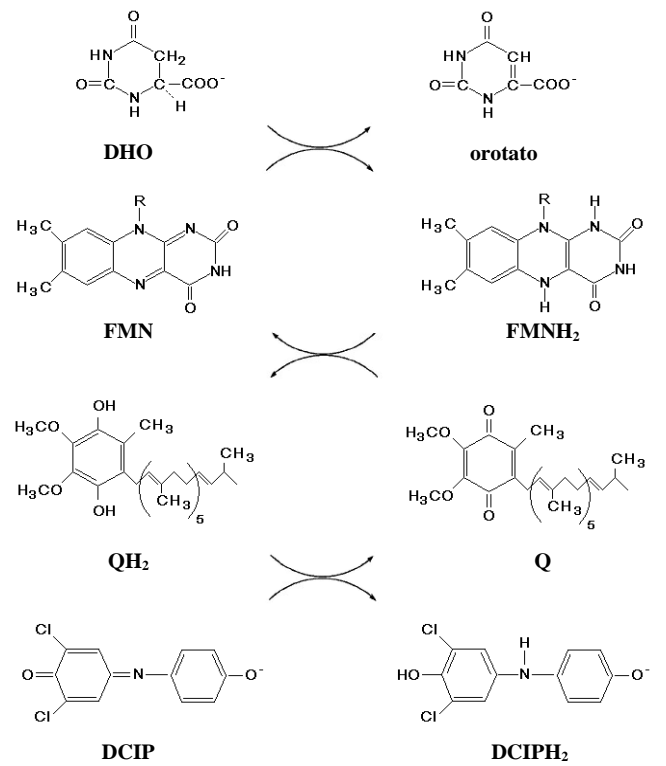

Figura 21 - Reação de óxido-redução catalisada pela DHODH onde o DCIP é o aceptor de elétrons final na reação. Durante a catálise, DHODH utiliza o FMN como cofator, para, na primeira parte da reação, promover a oxidação do substrato (DHO) enquanto FMN é reduzido. Na segunda parte da reação, $\mathrm{FMN}$ é reoxidado $\left(\mathrm{FMNH}_{2}\right.$ convertido em $\left.\mathrm{FMN}\right)$ através do auxílio de um segundo substrato, o agente oxidante, coenzima $Q_{6}$. Na terceira parte da reação, o DCIP é reduzido enquanto a coenzima $Q_{6}$ é oxidada.

A Figura 22 mostra a curva de absorção do DCIP em 610 nm na presença de DHO e da enzima EcDHODH. O ensaio enzimático foi realizado como descrito na seção materiais e métodos. Como pode ser observado os processos de expressão, purificação e concentração resultam em proteína ativa o que viabiliza a realização dos ensaios espectroscópicos com a amostra íntegra.

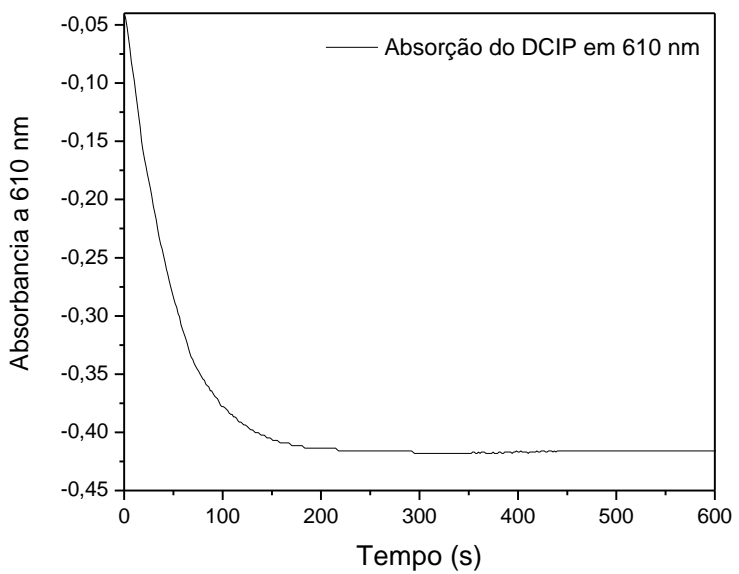

Figura 22 - Curva de absorção do DCIP em 610 nm. A redução na absorção do DCIP em $610 \mathrm{~nm}$ evidencia a atividade específica da EcDHODH, pois a medida que o DCIP é reduzido ele perde a cor azul tornando-se incolor. 


\subsubsection{Interação da EcDHODH com vesículas}

\subsubsection{Descrição qualitativa}

Os espectros de RPE do marcador de spin de cabeça polar (DPPTC) e dos marcadores da cadeia acil (5-, 10-, 12- e 16-PC) incorporados em vesículas mistas de DOPC/Triton X-100 e de DOPG/Triton X-100 na presença e ausência da EcDHODH estão mostrados nas Figuras 23 e 24. Somente mudanças míninas entre as linhas espectrais das amostras com e sem EcDHODH são detectadas para os marcadores DPPTC, 12-PC e 16PC, enquanto o surgimento de uma segunda componente espectral (pico agudo na linha de baixo campo de ressonância) é observado para os marcadores de spin 5- e 10-PC na presença da enzima. Nestes espectros bi-componentes, a maior contribuição é atribuída ao "bulk" de fosfolipídios marcados, enquanto a outra componente é atribuída a moléculas do marcador em contato com a proteína (chamados de lipídios de fronteira [71,72]). Uma análise qualitativa da componente extra sugere que um espectro constituído por linhas estreitas como aquelas observadas nas Figuras $23 \mathrm{~b}$ e c e $24 \mathrm{~b}$ e c poderia ser o resultado de um movimento muito menos restrito do marcador de spin quando ele está na vizinhança da enzima. O movimento mais rápido experimentado pelos marcadores nas vizinhanças da proteína resulta em uma média na anisotropia das interações magnéticas (hiperfina e Zeeman) deixando as linhas de ressonância mais estreitas do que normalmente observado para marcadores de spin experimentando movimento lento e anisotrópico. Um experimento controle usando a DHODH de T. cruzi, membro da classe 1 das DHODHs, e que portanto não apresenta a extensão $\mathrm{N}$-terminal, na presença dos mesmos sistemas de membranas modelo, não produziram alterações nos espectros de RPE para nenhum dos marcadores de spin testados (Figura 25).

A escolha por um fosfolipídio zwiteriônico, como o DOPC, ou um carregado negativamente, como o DOPG, parece não afetar a indução da componente de linhas estreitas quando na presença da enzima EcDHODH. Portanto, a carga superficial parece 
realmente não desempenhar um papel fundamental no processo de interação da EcDHODH com a membrana, uma vez que as mudanças observadas para os espectros dos marcadores de spin em vesículas mistas de DOPC (Figura 23) foram muito similares àquelas obtidas em vesículas mistas contendo DOPG (Figura 24).

Uma explicação para o surgimento desta segunda componente menos imobilizada nos espectros poderia ser a liberação de marcadores de spin livres em solução pelo rompimento das vesículas. As mudanças observadas para os espectros de DPPTC, 12-PC e 16-PC foram menores e ocorreram principalmente na linha de campo mais alto e no alargamento de cada uma das linhas hiperfinas, não havendo a segunda componente menos imobilizada. Caso o espectro de tal componente se devesse à liberação de marcadores de spin em solução, ele deveria ser observado para qualquer marcador de spin e não somente para o 5- e 10-PC. As medidas aqui apresentadas foram repetidas várias vezes para verificação da reprodutibilidade dos resultados. 


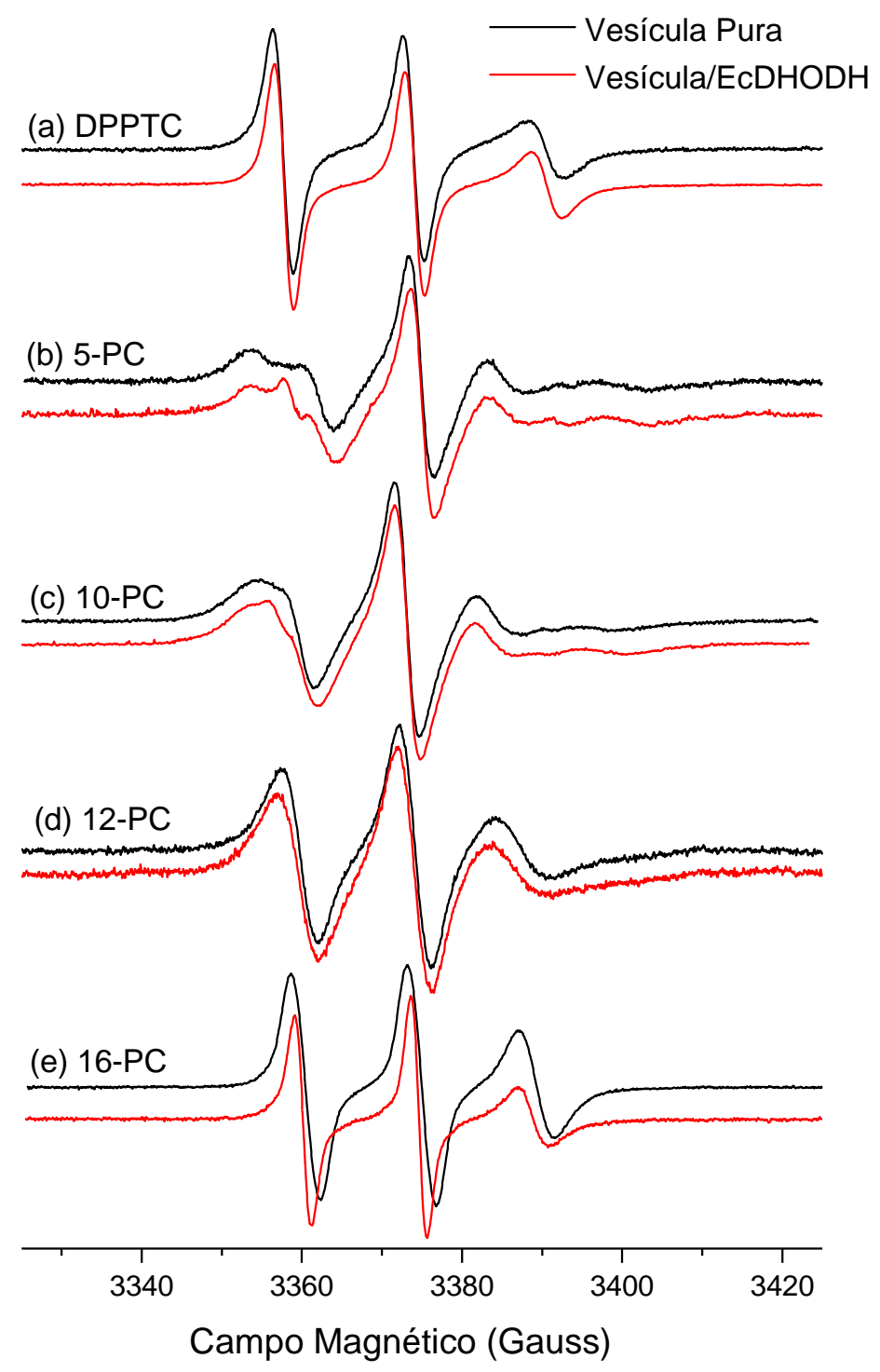

Figura 23 - Espectros de RPE dos marcadores DPPTC e n-PC ( $n=5,10,12$ e 16) em vesículas mistas de DOPC/Triton X-100 (linha preta) e de DOPC/Triton X-100/EcDHODH (linha vermelha). 


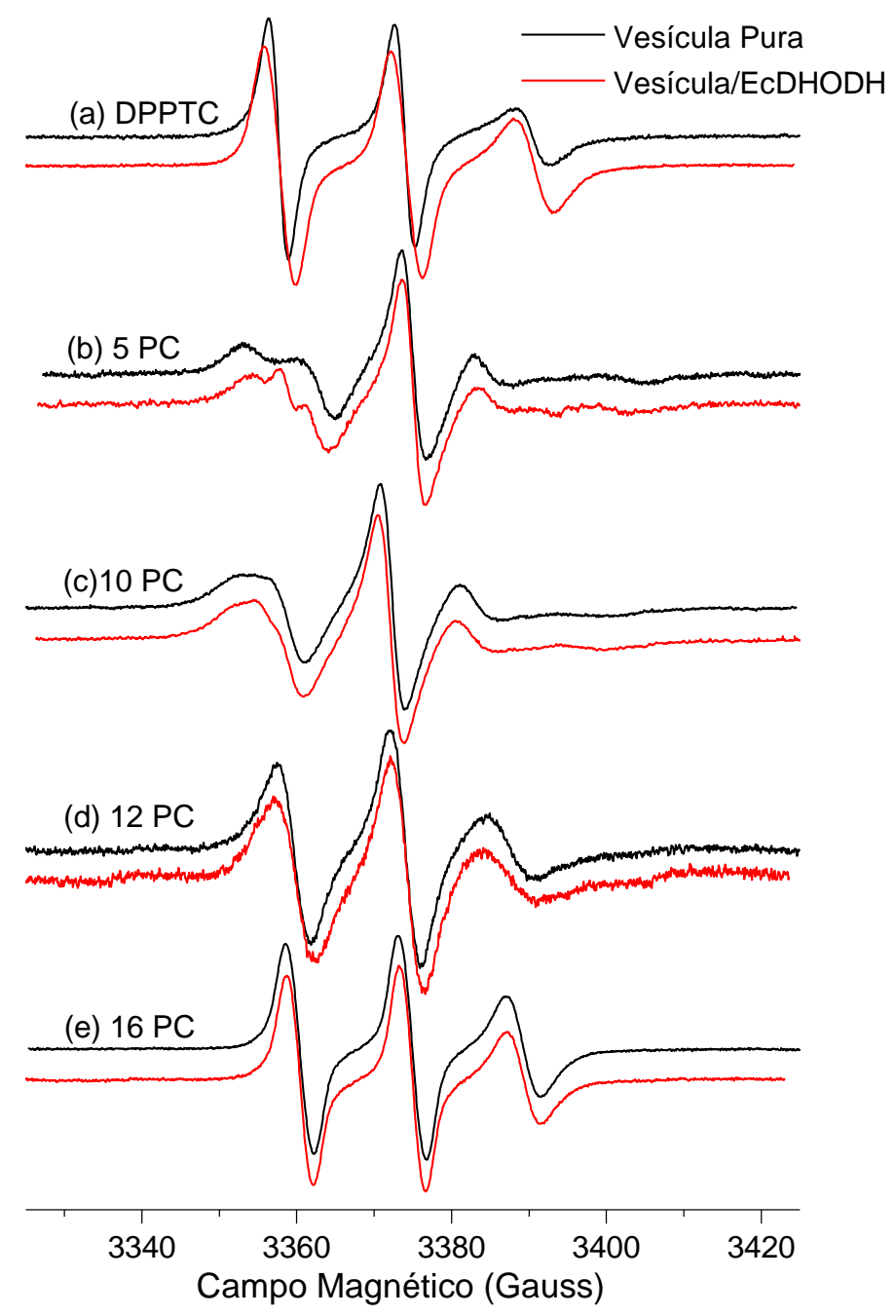

Figura 24 - Espectros de RPE em banda $X$ dos marcadores de spin em diferentes posições da cadeia acil do fosfolipídio: DPPTC (cabeça polar) e $n-P C(n=5,10,12$ e 16) incorporados a vesículas mistas de DOPG/Triton X-100 (linha preta) e de DOPG/Triton X-100/EcDHODH (linha vermelha). 


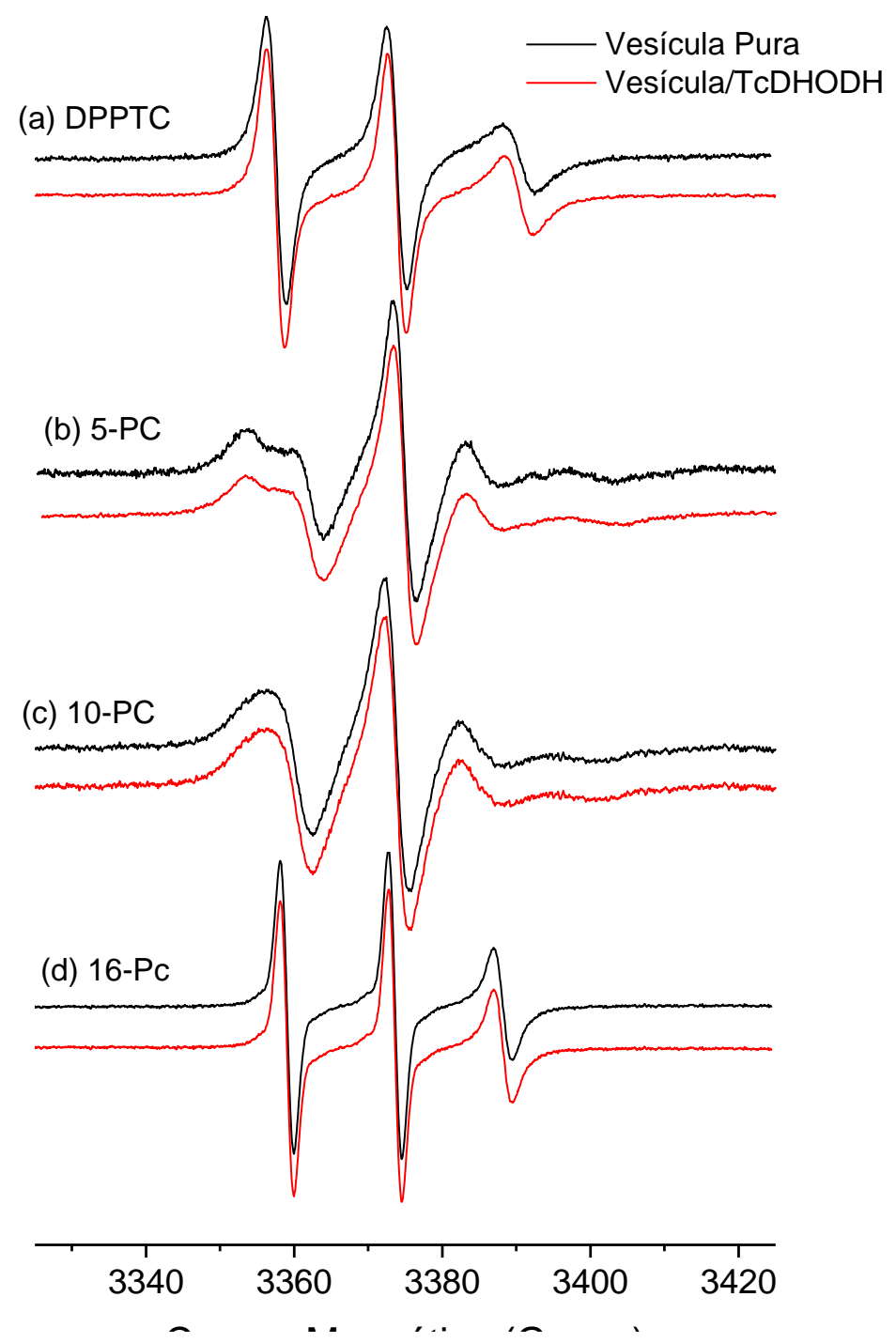

Figura 25 - Espectros de RPE em banda $X$ de marcadores de spin incorporados a vesículas mistas de DOPG/Triton X-100. Marcadores de spin DPPTC (cabeça polar) e $n-P C(n=5,12$ e 16) incorporados a vesículas mistas de DOPG/Triton X-100 (linha preta) e de DOPG/Triton X100/TcDHODH (linha vermelha).

Ainda sobre a origem da segunda componente espectral (Figuras 23 e 24), realizamos medidas de RPE em função do tempo do marcador de spin 5-PC em vesículas de DOPG/Triton X-100 contendo a enzima EcDHODH. Espectros foram medidos em intervalos de 5 minutos durante um período de aproximadamente duas horas. Cada espectro é resultado de medidas com duração de 10 minutos para a realização de médias a fim de melhorar a relação sinal/ruído. Os espectros obtidos estão mostrados na Figura 26 e, como pode ser observado, permaneceram inalterados com o tempo. A segunda componente 
é observada como um "spike" na linha de campo mais baixo, mas não tem sua intensidade aumentada em função do tempo como seria esperado caso o marcador estivesse sendo liberado gradualmente em solução. O último espectro, obtido após duas horas de medida, é absolutamente idêntico ao primeiro.

A análise conjunta dos espectros das Figuras 23, 24 e 26 leva-nos, portanto, a crer que o aparecimento da componente com linhas estreitas deve de fato ser resultado de uma desestruturação local da vesícula como conseqüência da ligação da enzima EcDHODH, que resulta na formação de uma estrutura do tipo poro ou um defeito (v. discussão adiante).

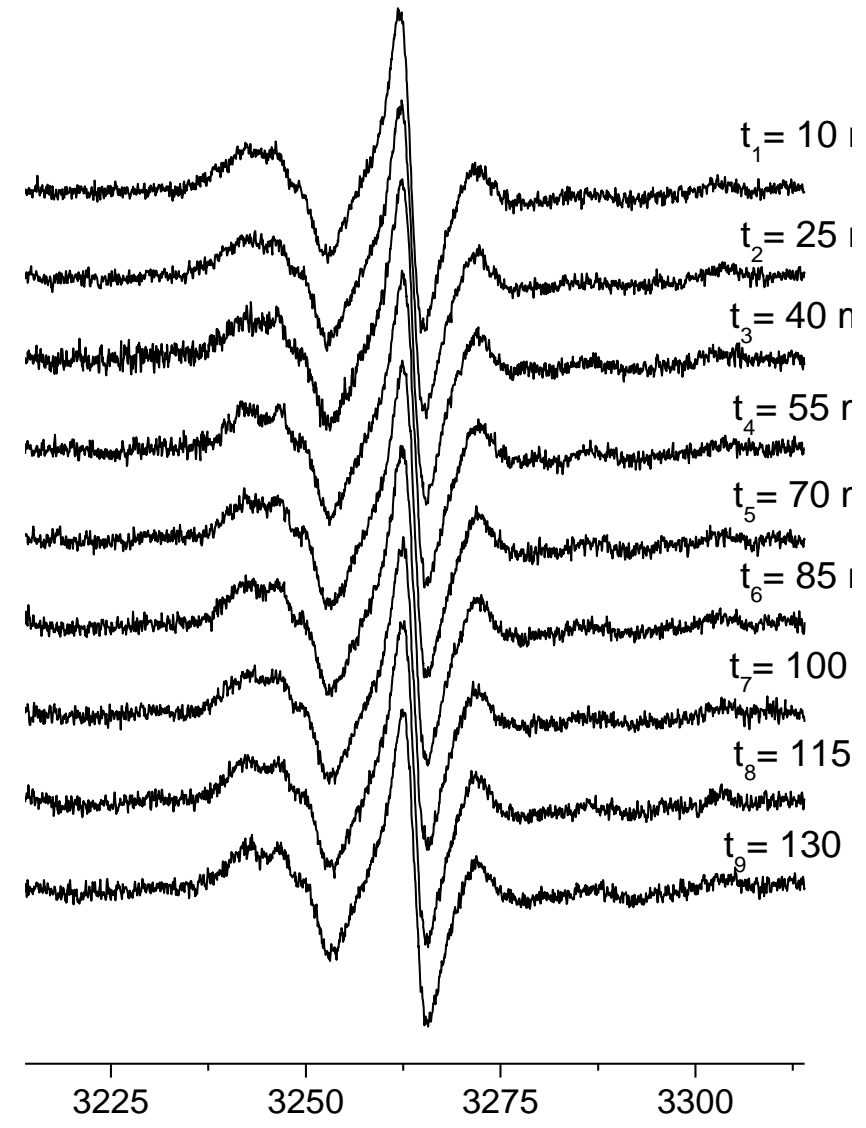

Figura 26 - Espectros de RPE do marcador 5-PC incorporado a vesículas de DOPG/Triton X100/EcDHODH. Cada medida teve duração de $10 \mathrm{~min}$ e pausa de $5 \mathrm{~min}$ foi dada entre cada experimento, $t_{n}(n=1$ a 9 ) são os tempos medidos ao término da aquisição de cada espectro tomando como tempo inicial ( $\mathrm{t}=0 \mathrm{~s}$ ) o início da aquisição do primeiro espectro. 


\subsubsection{Descrição quantitativa}

Para a simulação dos espectros de RPE apresentados nas Figuras 23 e 24 foi utilizado o programa Non-Linear Least Squares (NLSL) $[73,74]$ e visando um entendimento dos parâmetros obtidos através de tais simulações, é apresentado, agora, uma descrição semiqualitativa dos princípios básicos envolvidos nas simulações espectrais através do referido pacote de programas e que serão úteis quando da interpretação dos resultados obtidos. Cabe salientar que a discussão aqui apresentada se aplica a moléculas de fosfolipídios marcadas ao longo de sua cadeia carbônica e inseridas em vesículas mistas.

Primeiramente, faz-se necessária a descrição dos diversos sistemas de referência relevantes para as simulações em questão. Há quatro sistemas de coordenadas: o sistema de difusão molecular $\left(x^{\prime}, y^{\prime}, z^{\prime}\right)$, o sistema do diretor local $\left(x^{\prime \prime}, y^{\prime \prime}, z^{\prime \prime}\right)$, o sistema magnético $\left(x^{\prime \prime \prime}, y^{\prime \prime \prime}, z^{\prime \prime \prime}\right)$ e o sistema de laboratório $(x, y, z)$.

Os sistemas de referência mais triviais de serem definidos e visualizados são o sistema magnético $\left(x^{\prime \prime \prime}, y^{\prime \prime \prime}, z^{\prime \prime \prime}\right)$ e o de laboratório, sendo este último, como é usual, definido pela direção $z$ do campo magnético estático. Em relação ao sistema magnético são definidos os tensores $\boldsymbol{g}$ e $\boldsymbol{A}$. Os eixos $x^{\prime \prime \prime}$ e $z^{\prime \prime}$ são definidos paralelos às direções da ligação $\mathrm{N}-\mathrm{O}$ e do orbital $2 p_{z}$ do átomo de nitrogênio, respectivamente. O eixo $y^{\prime \prime}$ é definido de maneira a formar um sistema dextrógiro ortogonal com os outros dois eixos.

O sistema do diretor local $\left(x^{\prime \prime}, y^{\prime}, z^{\prime \prime}\right)$ é definido pela normal à superfície da membrana em cada ponto da mesma (vetor diretor local). A normal é, então, chamada de eixo $z^{\prime \prime}$, com ( $x^{\prime \prime}$ e $y^{\prime \prime}$ arbitrariamente escolhidos). O diretor local é usado para definir os ângulos $\psi$ referentes ao efeito MOMD descrito abaixo.

Para a definição do sistema molecular $\left(x^{\prime}, y^{\prime}, z^{\prime}\right)$, deve-se notar que a mobilidade rotacional de um marcador de spin pode ser caracterizada por duas taxas de difusão rotacional, $R_{\perp}$ e $R_{/ /}$, que representam os valores principais de um tensor de difusão com simetria axial. Na verdade, $R_{\perp}$ e $R_{/ /}$representam uma aproximação para os modos internos 
de rotação da cadeia e para o movimento geral da mesma [75]. O sistema de difusão molecular $\left(x^{\prime}, y^{\prime}, z^{\prime}\right)$ é, portanto, aquele no qual essas duas taxas são definidas. Mais especificamente, o eixo $z^{\prime}$ é feito paralelo ao eixo principal de simetria do segmento da molécula onde se encontra ligado o radical nitróxido. Portanto, $R_{/ /}$e $R_{\perp}$ são as taxas de difusão rotacional em torno do eixo $z^{\prime}$ e de um eixo perpendicular a ele, respectivamente. Em marcadores do tipo n-PC (n é a posição do radical N-O ao longo da cadeia lipídica, por exemplo 5,10 ou 16), $z^{\prime}$ é paralelo ao diretor local $z^{\prime \prime}$ (i.e., à própria cadeia lipídica) e $R_{\perp}$ representa o movimento oscilatório da respectiva porção da cadeia lipídica.

Em espectros de vesículas lipídicas, o efeito de Ordem Microscópica Desordem Macroscópica (MOMD - do inglês: Microscopic Order and Macroscopic Disorder) tem que ser levado em consideração durante as simulações. Isto quer dizer que diferentes segmentos da membrana lipídica estão aleatoriamente orientados em relação ao eixo $z$ do laboratório (direção de aplicação do campo magnético estático). O espectro de MOMD pode ser visto, então, como o espectro de uma amostra policristalina, sendo, portanto, representado por uma superposição de espectros oriundos de todos os fragmentos e que pode ser escrito como:

$$
S^{M O M D}=\int S(\psi) \operatorname{sen}(\psi) d \psi
$$

onde $S(\psi)$ é o espectro de um fragmento da membrana cujo vetor diretor faz um ângulo $\psi$ com o eixo $z$ do laboratório. Nas simulações aqui apresentadas, o espectro teórico final foi sempre obtido pela média sobre vinte diferentes valores de $\psi$.

Nas Figuras 27 e 28, é mostrado um resumo esquematizado do que foi dito acima em relação aos sistemas de eixos e estrutura geral das membranas. São apresentados os sistemas magnéticos $\left(x^{\prime \prime \prime}, y^{\prime \prime \prime}, Z^{\prime \prime \prime}\right)$ e moleculares $\left(x^{\prime}, y^{\prime}, z^{\prime}\right)$ para os marcadores de spin 16-PC, DPPTC. Na Figura 28, visualiza-se a definição do ângulo de "tilt" $\psi$ do vetor diretor em relação à direção do campo magnético estático (eixo $z$ ) e que leva ao chamado efeito MOMD. 
As simulações também incluem um parâmetro relacionado à mobilidade translacional do marcador caracterizada pela freqüência de Heisenberg "exchange", $\omega_{\text {exc }}$, que mede a taxa de colisão entre duas moléculas contendo o marcador de spin, e vários parâmetros relacionados a larguras de linha adicionais. Desses últimos, utilizamos um alargamento inomogêneo Gaussiano $\left(\Delta_{G}\right)$ isotrópico (i.e. afeta todas as linhas igualmente) e/ou um alargamento inomogêneo Lorentziano (W) isotrópico e que, essencialmente, representam inomogeneidades locais tanto do campo magnético interno da amostra (contribuição devido às interações superhiperfinas com prótons do solvente) quanto do campo externo gerado pelo equipamento.
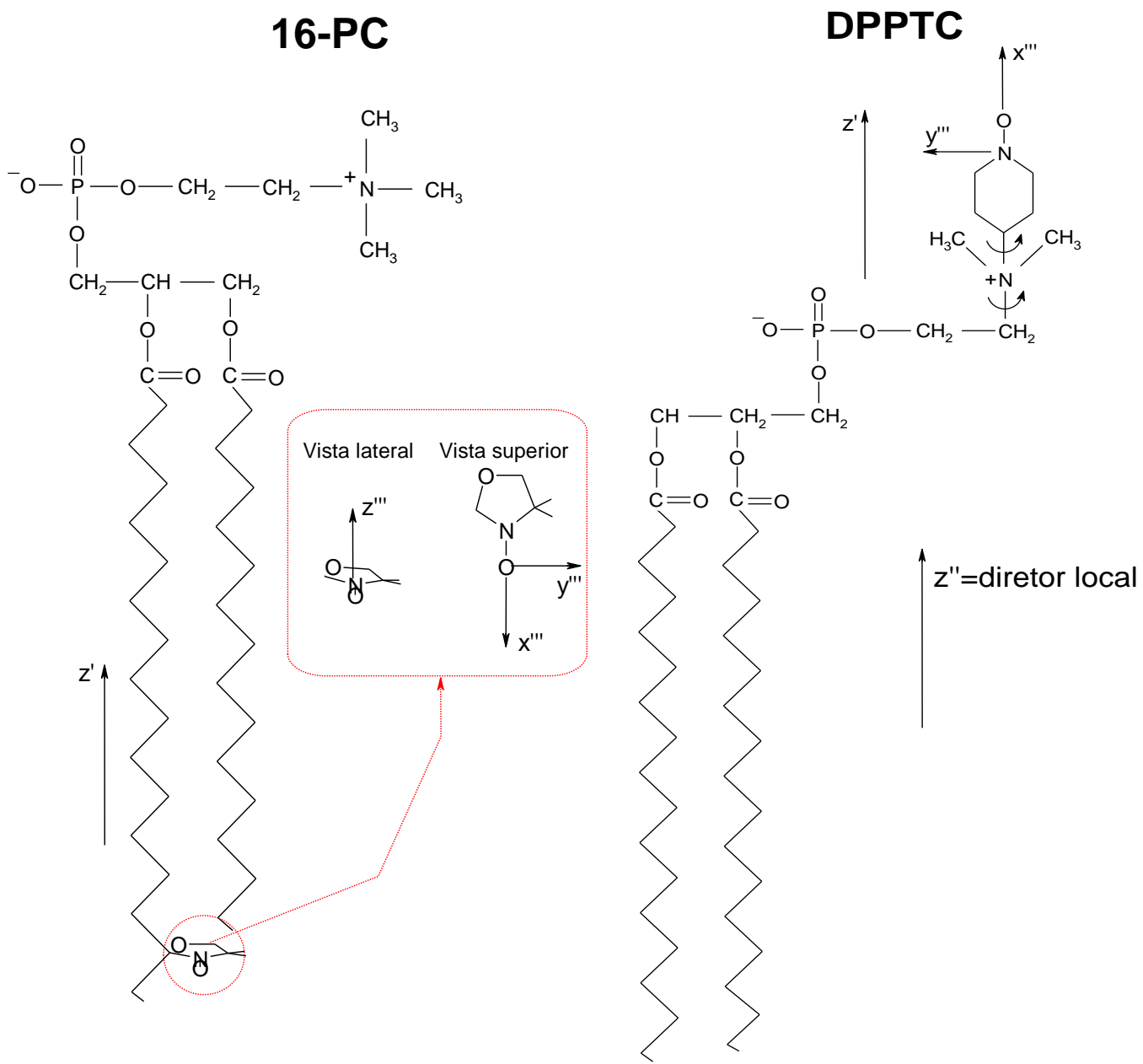

Figura 27 - Sistemas de eixos usados nas simulações de espectros de RPE para os marcadores de spin 16-PC e DPPTC. Os vetores z' em cada caso representam o eixo principal de alinhamento na membrana para o qual o movimento do nitróxido é sensível. 


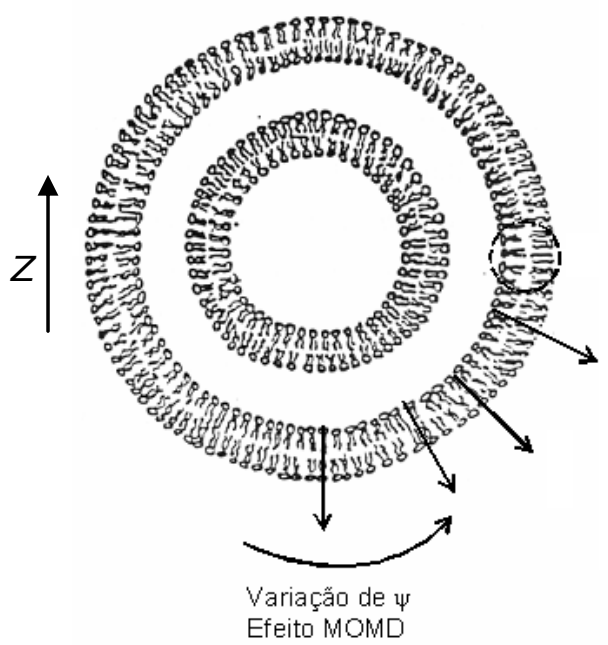

Figura 28 - Estrutura geral de dispersões usadas em medidas de RPE. O ângulo $\psi$ usado na definição do efeito MOMD ( $z$ define a direção do campo magnético externo) é mostrado. O esquema mostra a orientação do vetor diretor local $z^{\prime \prime}$ para alguns segmentos da membrana (setas acompanhando a variação de $\psi$ ). Figura adaptada da referência 76.

Como não há diferenças perceptíveis entre os espectros dos marcadores de spin incorporados em vesículas mistas de DOPC/Triton X-100 e DOPG/Triton X-100, tanto na ausência quanto na presença da enzima EcDHODH (Figuras 23 e 24). Decidimos por fazer a análise quantitativa dos espectros de RPE, através do programa de simulação NLSL, somente para os espectros provenientes dos marcadores de spin incorporados a vesículas mistas de DOPC/Triton X-100 contendo ou não a EcDHODH.

Os espectros experimentais de RPE dos marcadores de spin incorporados a vesículas mistas de DOPC/Triton X-100 e DOPC/Triton X-100/EcDHODH (Figura 23) podem ser divididos, basicamente, em duas categorias: espectros em que houve mudanças quando da adição da enzima, mas sem o aparecimento de uma segunda componente (marcadores DPPTC, 12-PC e 16-PC) e aqueles em que observa-se uma segunda componente menos imobilizada (marcadores 5-PC e 10-PC).

O procedimento adotado para a realização das simulações desses espectros através do programa NLSL foi tratar, primeiramente, os casos em que há espectros com uma única componente já que, obviamente, esta é a situação menos complexa tanto do ponto de vista físico/biofísico quanto computacional. Assim, os ajustes iniciais foram feitos para os 
espectros dos marcadores DPPTC, 5-, 10-, 12- e 16-PC em vesículas puras (sem EcDHODH) e de DPPTC, 12-, 16-PC em amostras contendo a enzima EcDHODH.

Os valores iniciais para os parâmetros magnéticos, $A_{x x}, A_{y y}, A_{z z}, g_{x x}, g_{y y}$ e $g_{z z}$, foram obtidos do trabalho de $\mathrm{Ge}$ et al. [77]. Durante o processo de simulação, os parâmetros magnéticos foram inicialmente fixados enquanto a componente do tensor de difusão rotacional $R_{\perp}$ foi variada. A seguir, variações nas componentes dos tensores $\mathbf{g}$ e hiperfino (A) foram introduzidas separadamente para evitar altos valores de correlação entre esses parâmetros. Uma vez obtido um ajuste razoável para a mistura contendo somente vesículas de DOPC/Triton X-100, os parâmetros obtidos foram usados como valores iniciais para os ajustes das amostras contendo EcDHODH. Os melhores ajustes obtidos estão mostrados na Figura 29 e os valores dos respectivos parâmetros estão listados na Tabela 5.

$\mathrm{Na}$ simulação do espectro bi-componente do marcador de spin 5-PC foi usado um conjunto diferente de parâmetros para cada componente. Para a componente mais intensa, os parâmetros determinados previamente para os espectros uni-componentes (Tabela 5) foram usados para calcular o espectro para a componente 1 (marcador no "bulk" da vesícula). Esses valores foram fixados e somente os parâmetros para o marcador nas vizinhanças da enzima (componente 2) foram permitidos variar. Os parâmetros obtidos para o melhor ajuste estão apresentados na Tabela 5 e os espectros calculados na Figura 30, onde são mostradas também as componentes individuais calculadas pelo programa NLSL. Como mencionado anteriormente, a componente 2 dá origem a parâmetros que são atribuídos a marcadores de spin em regime de movimento rápido. 


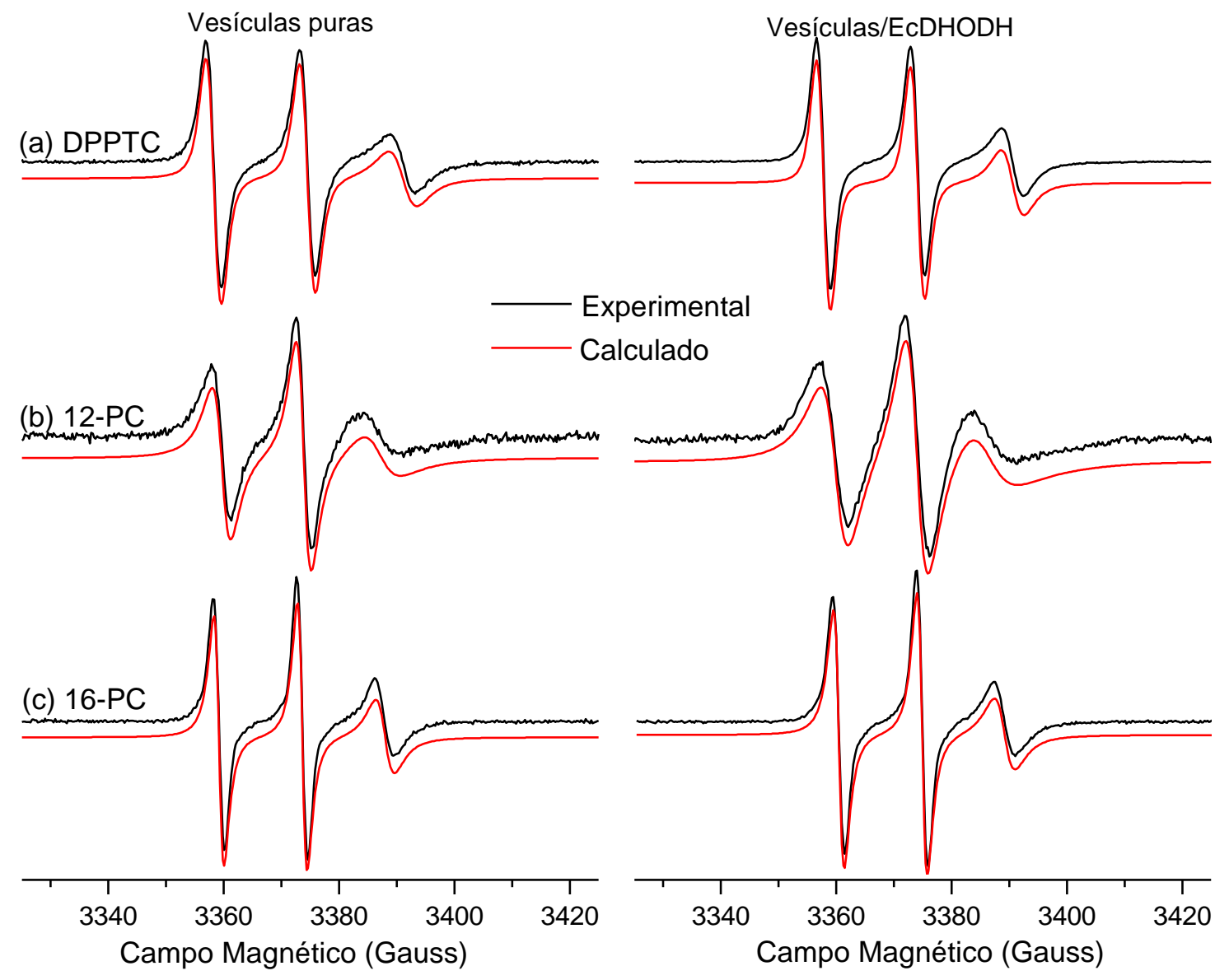

Figura 29 - Espectros experimentais e simulados dos marcadores de spin DPPTC, 12-PC e 16-PC em vesículas mistas de DOPC/Triton X-100. Espectros experimentais (linha preta) e simulados (linha vermelha). (A) DPPTC, (B) 12-PC e (C) 16-PC em micelas mistas de DOPC/Triton X-100 e DOPC/Triton X-100/EcDHODH. Condições de medida: freqüência 9,5 GHz; amplitude de modulação 1,0 G; freqüência de modulação $100 \mathrm{kHz}$; potência 40 $\mathrm{mW}$; varredura de campo $100 \mathrm{G}$. 


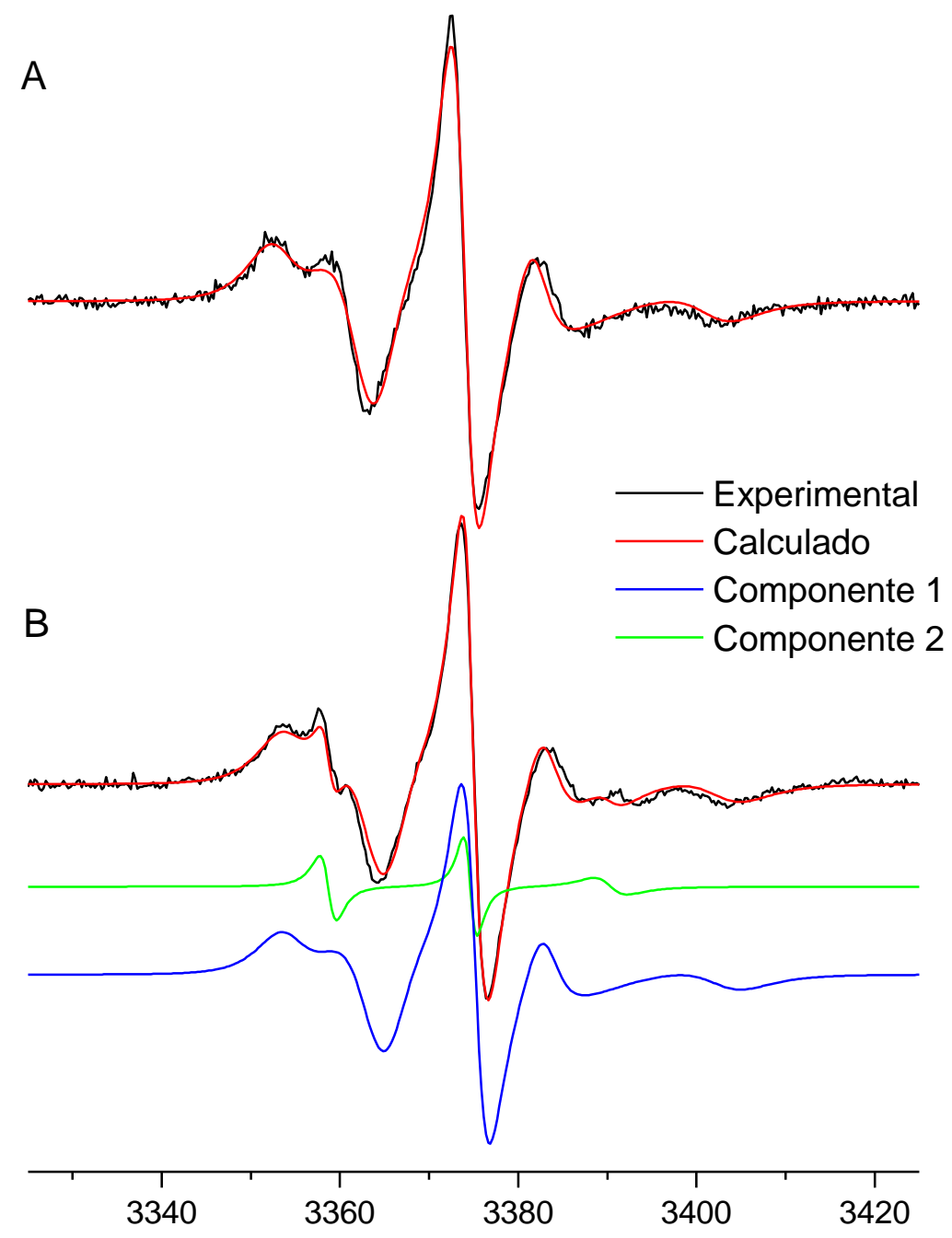

Figura 30 - Espectros experimental, calculado e das componentes individuais 1 e 2 do marcador de spin 5-PC em vesículas mistas de DOPC/Triton X-100 e DOPC/Triton X100/EcDHODH. Espectro experimental (linha preta), calculado (linha vermelha), componente1 (azul) e componente 2 (verde). (A) vesículas mistas de DOPC/Triton X-100 e (B) DOPC/Triton X100/EcDHODH. Condições de medida: freqüência $9,5 \mathrm{GHz}$; amplitude de modulação $1,0 \mathrm{G}$; freqüência de modulação 100 kHz; potência 40 mW; varredura de campo 100 G.

O espectro do marcador de spin 10-PC em misturas contendo a enzima foi tratado diferentemente do espectro do marcador 5-PC, descrito anteriormente. O programa NLSL não conseguiu tratar satisfatoriamente a segunda componente espectral, porque neste caso, a componente extra é vista como uma elevação de menos importância na linha de baixo campo (v. Figura 23), o que dificulta sobremaneira o processo de simulação. Mesmo usando 
dois conjuntos de parâmetros para simulação do espectro deste marcador em vesícula na presença da $\mathrm{EcDHODH}$, um deles foi tratado repetidamente como contribuição nula para o espectro total. Uma análise cuidadosa do espectro individual determinado para a componente 2 do marcador 5-PC em membranas modelo na presença da enzima EcDHODH (Figura 30B) sugere que a forma de linha obtida para o marcador 10-PC não é muito diferente daquela observada para a componente 2 do 5-PC. Para verificar está constatação, o espectro experimental do marcador 10-PC em vesículas puras (Figura 31A) foi somado manualmente ao espectro calculado do marcador 5-PC em EcDHODH/DOPC/Triton X-100 (componente 2, Figura 30B). As intensidades desses espectros foram ajustadas a fim de se obter a melhor reprodução das duas componentes do espectro experimental do marcador 10-PC em EcDHODH/DOPC/Triton X-100. Um ajuste muito bom entre o espectro soma final e o espectro experimental obtido para o marcador 10PC em DOPC/Triton X-100 na presença da EcDHODH foi obtido, como pode ser visto na Figura 31B. Isto indica que em contato com a EcDHODH os marcadores de spin 5 e 10-PC experimentam micro ambientes similares.

Para evitar mínimos locais durante o processo de minimização, os ajustes iniciais foram feitos a partir de vários conjuntos de valores de partida para os parâmetros do marcador "boundary". Esse procedimento também foi utilizado na obtenção de estimativas de erro para os diversos parâmetros (Tabela 5) 


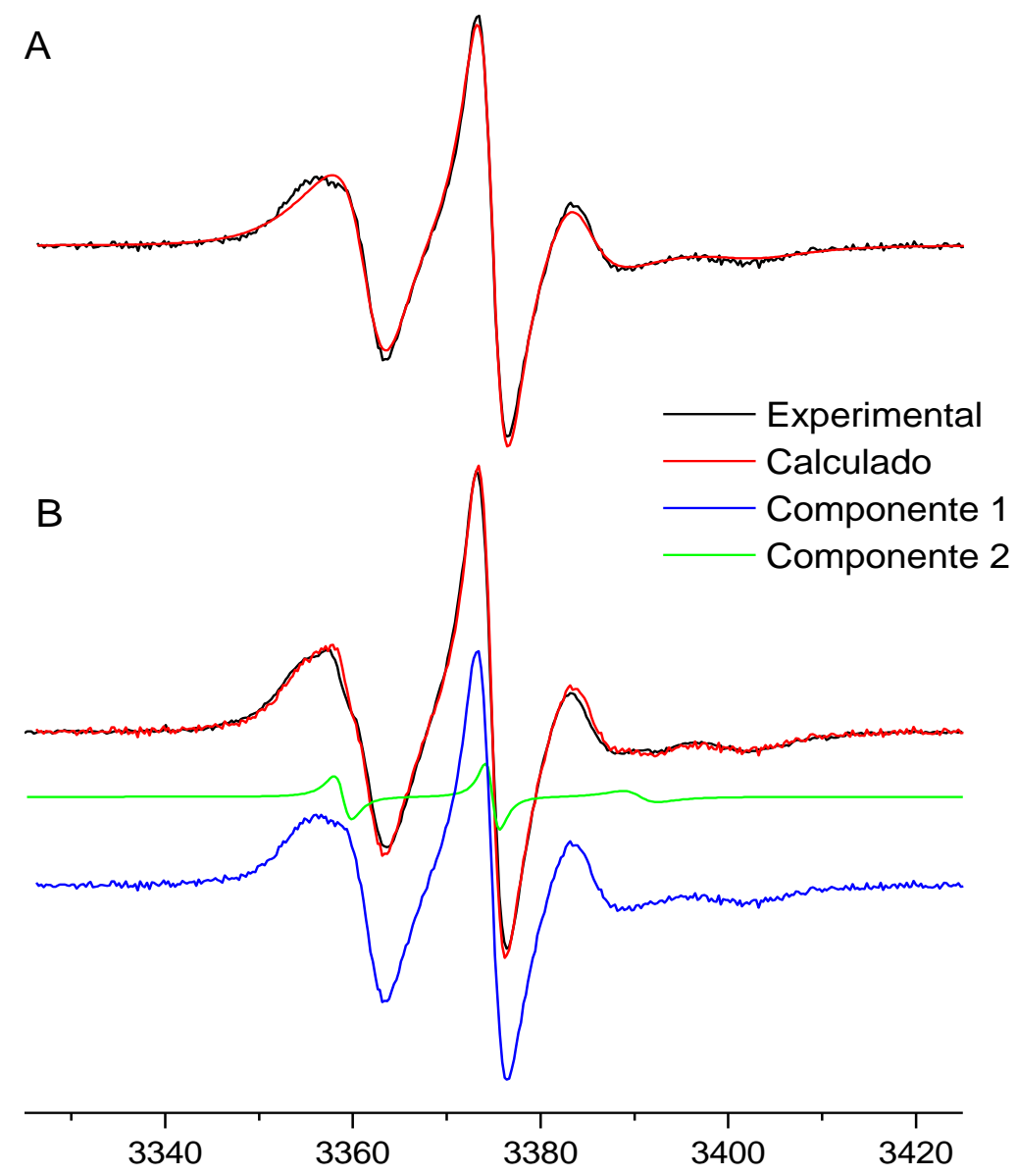

Figura 31 - Espectros experimental, calculado e componentes individuais 1 e 2 do marcador de spin 10-PC em vesículas mistas de DOPC/Triton X-100 e DOPC/Triton X-100/EcDHODH. Espectro experimental (linha preta), calculado (linha vermelha) e das componentes individuais 1 e 2 (azul e verde respectivamente). (A) vesículas mistas de DOPC/Triton X-100 e (B) DOPC/Triton X100/EcDHODH. Condições de medida: freqüência $9,5 \mathrm{GHz}$; amplitude de modulação 1,0 G; freqüência de modulação 100 kHz; potência 40 mW; varredura de campo $100 \mathrm{G}$. 
Tabela 5: Parâmetros obtidos a partir do melhor ajuste da simulação no programa NLSL dos espectros de RPE dos marcadores de spin DPPTC e n-PC (n = 5, 10, 12 e 16) incorporados a vesículas mistas de DOPC/Triton X-100 e DOPC/Triton X-100/EcDHODH.

\begin{tabular}{|c|c|c|c|c|c|c|c|c|c|}
\hline Amostra & Componente & $g_{x x}$ & $g_{y y}$ & $g_{z z}$ & $A_{x x}$ & $A_{y y}$ & $\overline{A_{z z}}$ & $A_{0}$ & $\begin{array}{c}R_{\perp} \\
\left(\times 10^{8} \mathrm{~s}^{-1}\right)\end{array}$ \\
\hline \multicolumn{10}{|c|}{ (A) Sem EcDHODH } \\
\hline DPPTC & 1 & 2,0078 & 2,0046 & 2,0022 & 6,0 & 5,9 & 37,5 & 16,5 & 0,58 \\
\hline $5-P C$ & 1 & 2,0075 & 2,0049 & 2,0020 & 7,4 & 6,5 & 30,2 & 14,7 & 0,22 \\
\hline $10-P C$ & 1 & 2,0084 & 2,0063 & 2,0033 & 6,5 & 6,0 & 31,4 & 14,6 & 0,36 \\
\hline $12-P C$ & 1 & 2,0089 & 2,0063 & 2,0033 & 5,3 & 4,9 & 33,2 & 14,5 & 0,79 \\
\hline $16-P C$ & 1 & 2,0102 & 2,0063 & 2,0033 & 5,3 & 4,9 & 33,2 & 14,5 & 1,94 \\
\hline \multicolumn{10}{|c|}{ (B) Com EcDHODH } \\
\hline DPPTC & 1 & 2,0078 & 2,0047 & 2,0022 & 6,0 & 4,9 & 37,8 & 16,2 & 0,78 \\
\hline \multirow[t]{2}{*}{ 5-PC } & 1 & 2,0075 & 2,0049 & 2,0020 & 7,4 & 6,5 & 30,2 & 14,7 & 0,22 \\
\hline & 2 & 2,0068 & 2,0047 & 2,0015 & 6,5 & 5,2 & 36,3 & 16,0 & 1,47 \\
\hline $12-\mathrm{PC}$ & 1 & 2,0090 & 2,0063 & 2,0033 & 5,3 & 4,9 & 33,3 & 14,5 & 0,66 \\
\hline $16-P C$ & 1 & 2,0102 & 2,0063 & 2,0033 & 5,3 & 4,9 & 33,3 & 14,5 & 1,69 \\
\hline
\end{tabular}

${ }^{+}$Componentes do tensor $A$ estão em Gauss.

${ }^{\S} A_{0}=\left(A_{\mathrm{xx}}+A_{\mathrm{yy}}+A_{\mathrm{zz}}\right) / 3$.

Erros estimados: $\mathrm{R}_{\perp}(5 \%), A_{\mathrm{xx}}$ e $A_{\mathrm{yy}}(10 \%), A_{\mathrm{zz}}(5 \%)$ 


\subsubsection{Mecanismo proposto para a ligação EcDHODH-vesículas}

O parâmetro hiperfino isotrópico $A_{0}\left(A_{0}=\left(A_{\mathrm{xx}}+A_{\mathrm{yy}}+A_{\mathrm{zz}}\right) / 3\right.$.) é uma medida da polaridade relativa em torno do grupo nitróxido $[78,79]$. Quanto maior o valor de $A_{0}$, mais hidrofílico o ambiente nas vizinhanças do marcador. Da Tabela 5, pode-se verificar que o marcador da cabeça polar DPPTC, como esperado, está em um ambiente muito mais hidrofílico do que os outras sondas, com valor de $A_{0}(16,5 \mathrm{G})$ comparável àquele obtido para marcadores de spin livres em solução aquosa ( $A_{0}$ da ordem de $16,9 \mathrm{G}$ ). Da região da cabeça polar para o interior da vesícula, o valor de $A_{0}$ diminui significativamente de $16,5 \mathrm{G}$ para $14,7 \mathrm{G}$. $\mathrm{Na}$ região hidrofóbica da vesícula, o valor de $A_{0}$ apresenta pequena variação decrescente (Tabela 5A), indicando que o interior da vesícula não mostra alterações abruptas em sua polaridade. O mesmo comportamento é observado para a componente 1 quando a enzima EcDHODH é adicionada (Tabela 5B - componente 1). Ou seja, a presença da proteína não modifica a acessibilidade ao solvente (ou a outras moléculas polares) das cadeias carbônicas hidrofóbicas para as moléculas de surfactantes/fosfolipídios que não interagem diretamente com a EcDHODH (“bulk”).

Por outro lado, um aumento considerável na polaridade (14,7 G para 16,0 G) é observado para a componente 2 dos espectros dos marcadores 5- e 10-PC na presença da EcDHODH. Este resultado pode ser racionalizado em termos da composição residual do domínio N-terminal da EcDHODH, que supostamente é aquele responsável pela interação com a membrana. Uma análise do padrão de hidrofobicidade/hidrofilicidade dos resíduos das duas a-hélices e uma hélice $3_{10}$ que compõem o domínio $\mathrm{N}$-terminal através do programa ProtScale (Figura 32) nos permitiu inferir que essa região não apresenta na sua parte externa (apontando em sentido oposto ao da estrutura do barril $\alpha / \beta$ que forma o core da proteína) um excesso de resíduos hidrofóbicos. Além disso, não há uma concentração de resíduos carregados orientados na direção do barril. Ou seja, a região apresenta um caráter anfipático com regiões hidrofílicas e hidrofóbicas se alternando (Figura 32). A presença de 
um número significativo de resíduos polares pode explicar o aumento da polaridade observado para a componente 2 do espectro do marcador de spin 5-PC. A distribuição de resíduos no domínio $\mathrm{N}$-terminal tornaria possível a adesão da enzima à membrana, mas tornaria muito improvável sua total integração à mesma [22]. Nossos resultados de RPE estão de acordo com está hipótese de interação periférica entre a EcDHODH e a membrana bacteriana, pois mudanças significativas são observadas entre os carbonos 5 e 10 da cadeia acil. Entretanto, a profundidade de penetração da proteína em membranas mistas não pode ser rigorosamente determinada por nossos experimentos, devido à estrutura pouco organizada no core dessas membranas mistas. Todavia, podemos concluir que as modificações induzidas pela presença da enzima ocorrem de uma forma localizada. Além disso, o uso de uma enzima da classe 1, a TcDHODH, em experimentos de RPE similares não resultou em alterações nos espectros (Figura 25), sugerindo que a extensão N-terminal é a responsável pela interação proteína/membrana.

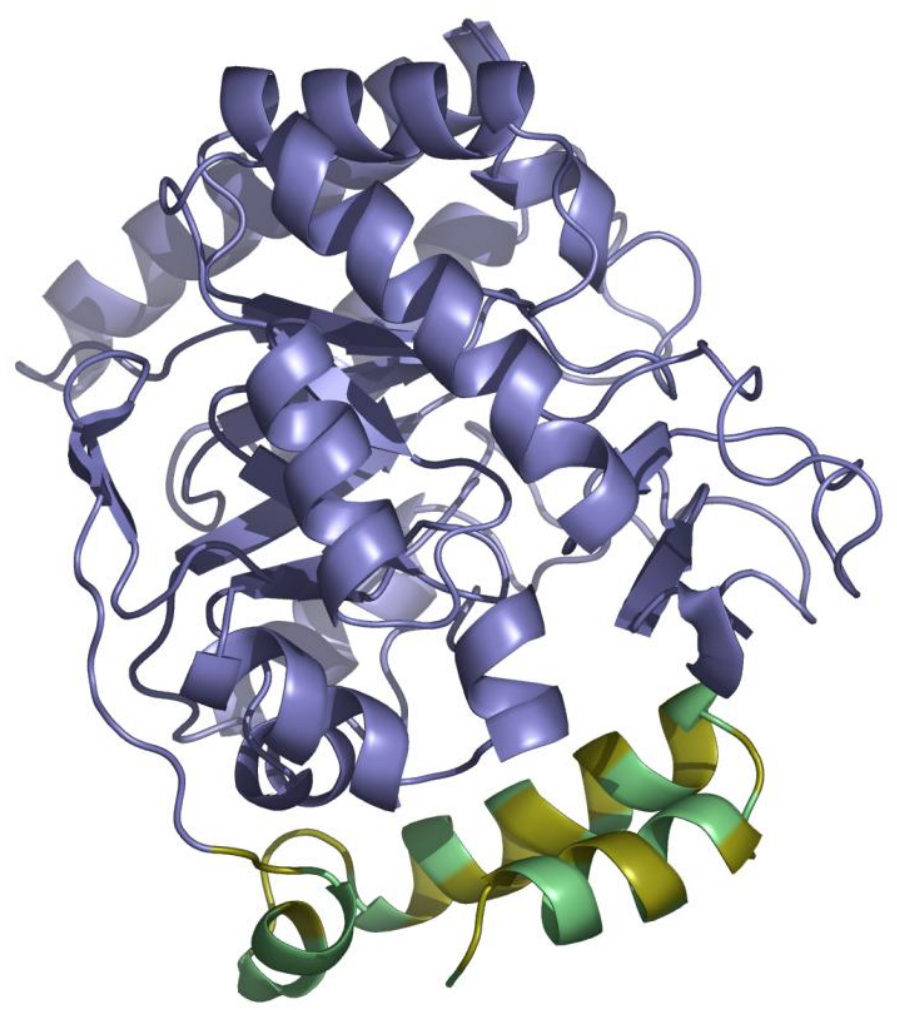

Figura 32 - Estrutura cristalográfica da enzima EcDHODH. Os resíduos verdes e amarelos ilustram o domínio $\mathrm{N}$-terminal e representam resíduos hidrofóbicos e hidrofílicos, respectivamente. $\mathrm{O}$ padrão de hidrofobicidade/hidrofilicidade foi determinado através do programa ProtScale [80] e a figura foi visualizada utilizando-se o programa PyMol [57]. 
A dinâmica das várias moléculas de marcador de spin no interior das vesículas pode

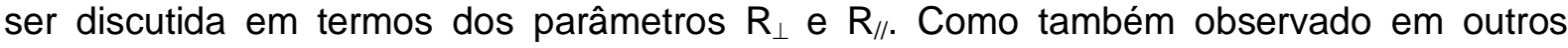
trabalhos onde se fez uso do programa NLSL [81-83], nossos resultados foram insensíveis à variações dos valores de $R_{/ /}$. Este valor foi, então, fixado em $R_{/ /}=10 R_{\perp}$ durante todas as simulações. Os valores de $R_{\perp}$ seguem um gradiente crescente quando vamos descendo ao longo da cadeia acil do marcador de spin (Tabela 5A), compatível com a estrutura pouco organizada e altamente flexível do interior de vesículas mistas de fosfolipídios/detergente. $\mathrm{O}$ marcador de cabeça polar DPPTC apresenta mobilidade alta devido à sua exposição ao solvente.

Quando da adição da EcDHODH, observa-se um aumento no valor de $R_{\perp}$ do marcador DPPTC e um decréscimo nos valores de $R_{\perp}$ para os marcadores localizados no "bulk" (componente 1) da região hidrofóbica da vesícula (Tabela 5B). A proteína diminui, portanto, a fluidez desta região e causa maior mobilidade da cabeça polar, provavelmente pela quebra de ligações de hidrogênio que seriam feitas pelo DPPTC com moléculas do solvente. Em relação à componente 2 do marcador 5-PC (Tabela 5B), assim como obtido para $A_{0}$, também o valor do parâmetro $R_{\perp}$ aumenta significativamente $\left(1,47 \times 10^{8} \mathrm{~s}^{-1}\right)$ quando comparado ao valor de $\mathrm{R}_{\perp}$ para o mesmo marcador localizado no "bulk" da vesícula $(0,22 \mathrm{x}$ $\left.10^{8} \mathrm{~s}^{-1}\right)$, atingindo uma mobilidade próxima daquela observada para o marcador 16-PC.

Os resultados apresentados acima nos permitem concluir que a adição da enzima gera um efeito espaçador na região compreendida entre os carbonos 5 e 10 da vesícula. A definição precisa dessa região é difícil já que vesículas mistas não são tão bem estruturadas enquanto bicamadas lipídicas. Mesmo assim, um modelo para a acomodação periférica da proteína pode ser proposto. Os altos valores de $A_{0}$ e $R_{\perp}\left(16,0\right.$ G e $1,47 \times 10^{8} \mathrm{~s}^{-1}$ respectivamente) para a componente 2 dos marcadores 5- e 10-PC indicam que uma espécie de "defeito" estrutural é gerado na membrana pela adesão do domínio N-terminal à vesícula, sem sua total penetração na vesícula (mudanças apenas pequenas nos espectros a partir do marcador 12-PC). A formação de "defeitos" em bicamadas foi detectada 
anteriormente por RPE [84-86]. Kleinschmidt et al. relataram a existência de uma componente estreita no espectro de RPE de um ácido esteárico marcado incorporado em bicamadas de DTPG após a adição de melitina [84]. Ge et al. mostraram que a ligação do fator 6 de ribosilação de ADP (ARF6), um ativador da fosfolipase $D$, em vesículas de fosfatidilinositol 4,5-bifosfato $\left(\mathrm{PIP}_{2}\right)$ cria um defeito na bicamada na região do grupo polar e/ou próximo da posição $n=8,10$ da cadeia acil [85]. Além disso, Ge et al. concluíram que a componente menos imobilizada pode ser significativamente aumentada ou reduzida através de interações lipídio/lipídio ou lipídio/proteína específicas.

A formação desse "defeito" parece desempenhar um papel fundamental no ciclo catalítico da enzima pois a região do $\mathrm{N}$-terminal é também aquela responsável pelo controle do acesso ao sítio ativo da proteína. A estrutura cristalográfica da HsDHODH em complexo com diferentes inibidores mostrou que o N-terminal contém o sítio de ligação da quinona [21]. O domínio $N$-terminal atua como uma "tampa" do interior do barril $\alpha / \beta$, blindando o cofator FMN do solvente [22]. Quando aderida à membrana, o domínio N-terminal induz o aparecimento do referido "defeito", de modo que quinonas dispersas na membrana, as quais atuam como aceptores de elétrons na segunda metade da reação de oxi-redução catalisada pela EcDHODH, possam se ligar à proteína. Assim, a formação do "defeito" séria crucial para que a catálise enzimática ocorra.

\subsubsection{Medidas de RPE em função da temperatura}

Para testar a influência da presença da EcDHODH sobre a estrutura dinâmica das vesículas no que diz respeito a alterações no comportamento termotrópico dos seus constituintes, experimentos de RPE com variação de temperatura foram realizados. Embora não se possa definir precisamente a temperatura de transição de fase no caso de uma mistura como fosfolipídio/Triton X-100, ainda assim as referidas medidas foram realizadas. Neste caso, foram usadas vesículas fosfolipídicas de DMPC marcadas com o marcador de 
spin 5-PC. Este fosfolipídio foi escolhido por ter sua temperatura de transição da fase gel para fase fluída em torno de $24{ }^{\circ} \mathrm{C}$, o que possibilita o acompanhamento de possíveis mudanças com experimentos em torno da temperatura ambiente. A razão lipídio/proteína usada foi de 20 e os espectros obtidos estão apresentados na Figura 33. Diferenças claras, principalmente na linha em campo mais baixo, podem ser observadas em quase todo o intervalo de temperatura. Esses experimentos servem para evidenciar mais uma vez a interação da EcDHODH com modelos de membrana.

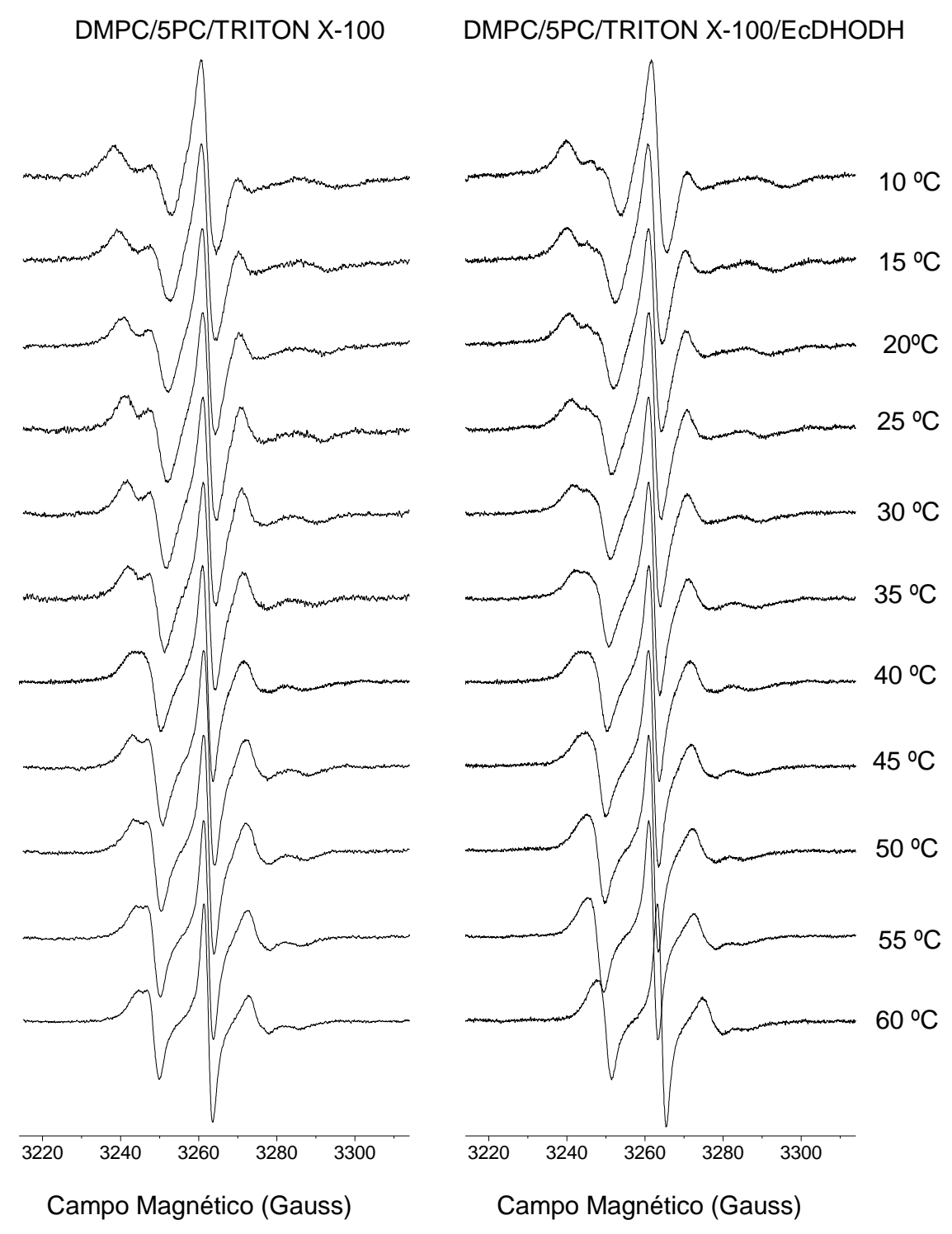

Figura 33 - Espectros de RPE do marcador 5 PC incorporado a vesículas de DMPC/Triton X100 e DMPC/Triton X-100/EcDHODH em diferentes temperaturas. $\grave{A}$ esquerda, espectros de controle (DMPC/Triton X-100/5PC) e à direita espectros do marcador na presença de DMPC/Triton X100 e EcDHODH. 


\subsubsection{Comportamento da EcDHODH na ausência de Triton X-100}

Como discutido na seção 4.2.2.2, o detergente Triton X-100 desempenha um papel fundamental no que diz respeito ao estado de oligomerização da enzima EcDHODH. De acordo com os experimentos de sedimentação por centrifugação em gradiente de sacarose realizados por Björnberg et al. [19], na ausência deste, ocorre a oligomerização das moléculas de proteína, sendo o grau de oligomerização dependente da concentração de detergente. Assim, foram realizadas medidas de RPE do marcador de spin 5-PC em vesículas lipídicas de DOPC na presença da enzima EcDHODH após remoção do Triton X100 oriundo do processo de purificação, com o objetivo de investigar se o estado de oligomerização é de fato induzido pelo caráter hidrofóbico do domínio N-terminal da proteína. A remoção do surfactante da amostra protéica foi realizada como descrito na seção 4.1.6 através do uso da resina Calbiosorb adsorvent (biobeads). A calbiosorb adsorvent é uma resina hidrofóbica processada para eliminar contaminantes orgânicos livres em solução, como sais e íons de metais pesados, e é preparada especialmente para remover detergentes de meios aquosos. De acordo com o manual da referida resina, a capacidade de absorção da resina, no caso do Triton X-100, é de $157 \mathrm{mg}$ do detergente para cada $1 \mathrm{~mL}$ de resina.

Como pode ser observado na Figura 34B, não há mudanças perceptíveis nos espectros de RPE do marcador de spin 5-PC em vesículas na presença da enzima EcDHODH após remoção do detergente Triton X-100. Enquanto que quando a mesma medida é realizada com o detergente incluído no processo de purificação, mudanças são induzidas no espectro (Figura 34A). Isso torna claro que a formação de oligômeros e/ou agregados leva à oclusão do domínio N-terminal (domínio de interação proteína-membrana), diminuindo ou mesmo impedindo tal interação. 

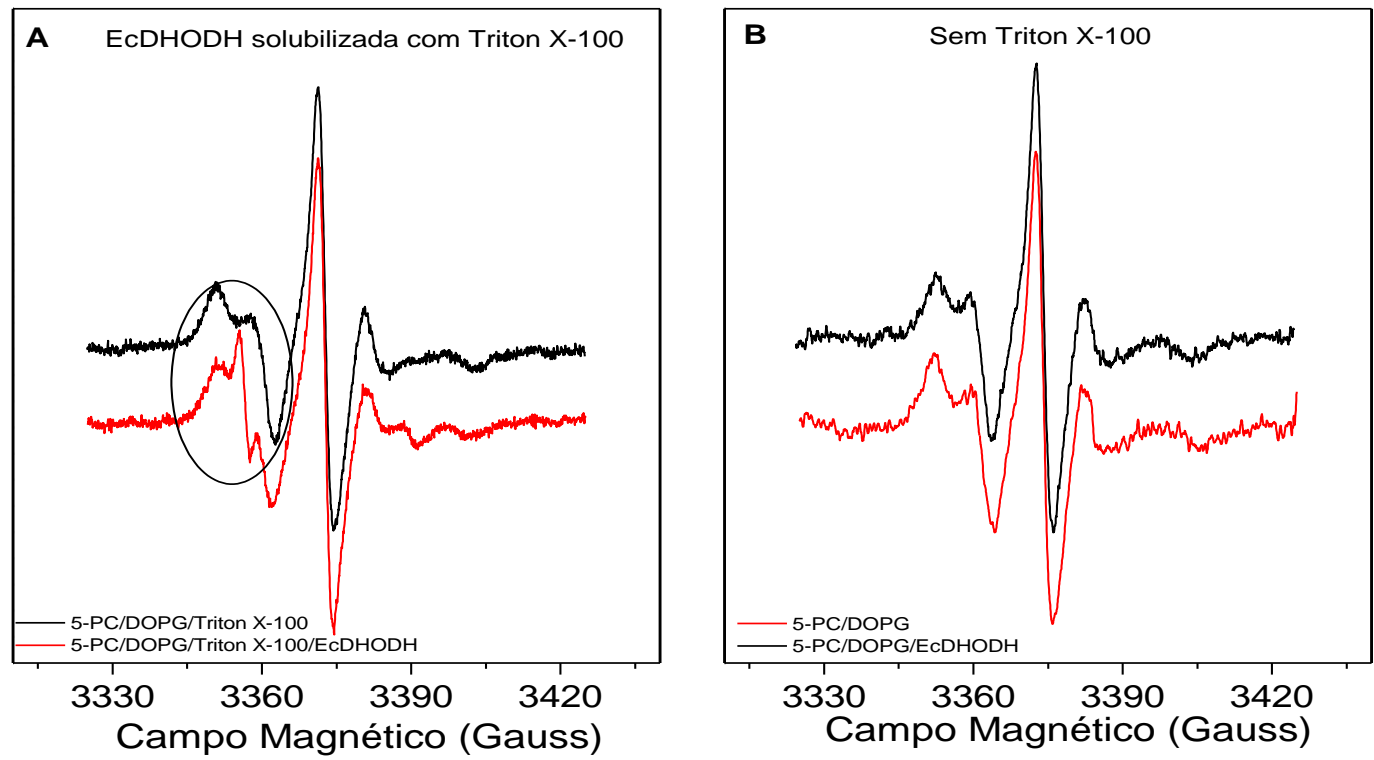

Figura 34 - Espectros de RPE do marcador de spin 5-PC incorporado a vesículas multilamelares de DOPG/Triton X-100 e de DOPG/Triton X-100/EcDHODH. (A) DOPG/Triton X-100 (linha preta) e DOPG/Triton X-100 com a enzima EcDHODH (linha vermelha); (B) DOPG (linha preta) e DOPG com a enzima (linha vermelha). O círculo em (A) destaca a mudança na linha de campo mais baixo quando da ligação da EcDHODH.

\subsubsection{Interação com vesículas na presença de ligantes}

Ainda com o intuito de investigar o mecanismo de interação EcDHODH-membrana, procedemos com medidas de RPE do marcador de spin 5-PC em vesículas de DOPC/Triton $\mathrm{X}-100$ contendo a enzima EcDHODH na presença de alguns dos seus ligantes, tais como: diidroorotato, orotato e quinona (coenzima $Q_{6}$ ). A Figura 35 mostra os espectros gerados a partir destes experimentos. Nos casos onde os ligantes estavam contidos na amostra é notado também o surgimento da segunda componente menos imobilizada na linha de baixo campo, como ocorre no caso livre de ligantes da EcDHODH. Tal componente aparece menos pronunciada apenas quando quinona é adicionada na presença do diidroorotato. Isso provavelmente ocorre devido ao fato da quinona, que é lipossolúvel, se ligar à enzima através da região $\mathrm{N}$-terminal alterando a interação enzima-vesícula. Esta constatação está de acordo com o mecanismo empregado pela DHODH durante a reação catalítica in vivo, 
pois, a célula captura quinonas do sistema respiratório através do domínio $\mathrm{N}$-terminal para promover a catálise [19].

Os espectros do marcador 5-PC em vesículas de DOPC/Triton X-100 (sem a EcDHODH) contendo os ligantes foram idênticos àqueles obtido para o marcador de spin na ausência dos ligantes (v. Figura 23), por está razão somente um espectro controle está apresentado na Figura 35.

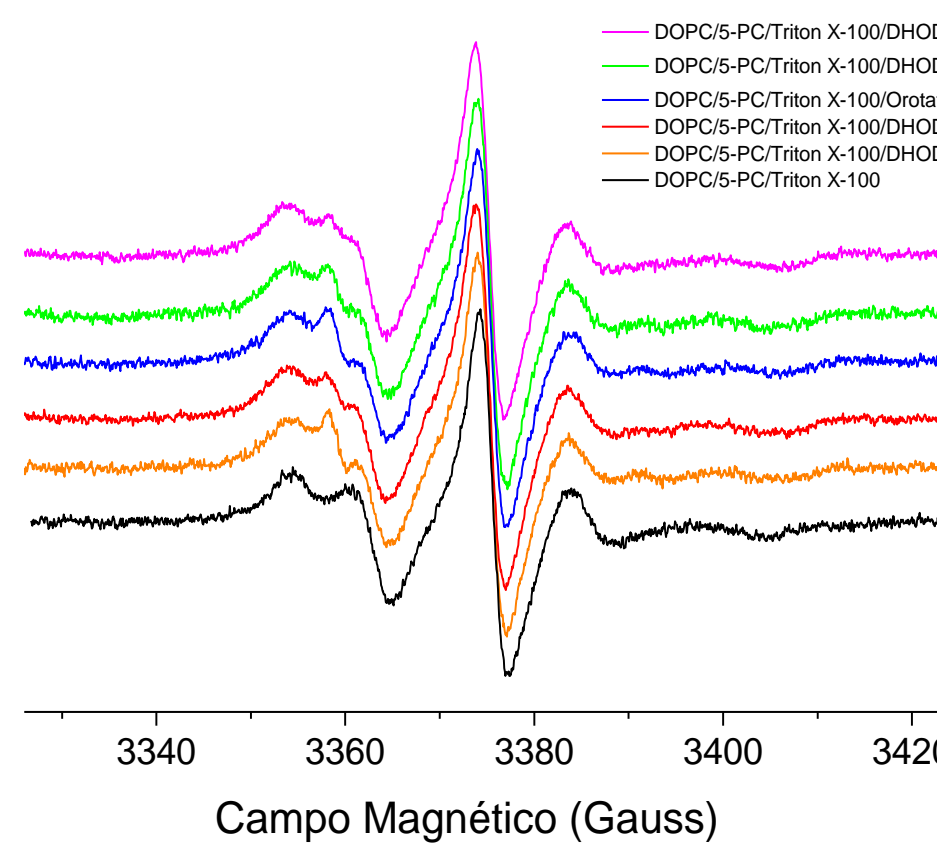

Figura 35 - Análise por RPE do efeito de ligantes da EcDHODH sobre a interação proteínamembrana. Espectros de RPE do marcador 5-PC em vesículas de DOPC/Triton X-100/EcDHODH na presença dos ligantes da EcDHODH: Diidroorotato, orotato e quinona.

\subsubsection{Marcação de spin sítio dirigida em EcDHODH}

Com a finalidade de investigar a dinâmica experimentada pela extensão $\mathrm{N}$-terminal da enzima EcDHODH através da técnica de SDSL, foram introduzidas oito mutações (uma por vez) ao longo da cadeia $\mathrm{N}$-terminal da $\mathrm{EcDHODH}$, região supostamente responsável pelo contato da enzima com a membrana. As posições dos resíduos mutados ao longo 
dessa região estão mostradas em verde na Figura 36A e B, e destacadas em vermelho na seqüência de aminoácidos da EcDHODH (Figura 36C). As posições para a incorporação dos mutantes foram escolhidas para aminoácidos localizados em diferentes regiões da região $\mathrm{N}$-terminal, onde, baseado na estrutura cristalográfica de $\mathrm{EcDHODH}$, apresentam diferentes níveis de acessibilidade ao solvente, flexibilidade e características químicas. As mutações realizadas correspondem as posições da Tyr2, Phe5, Lys8, Phe11, His19, Phe21, Phe23 e Gln25.

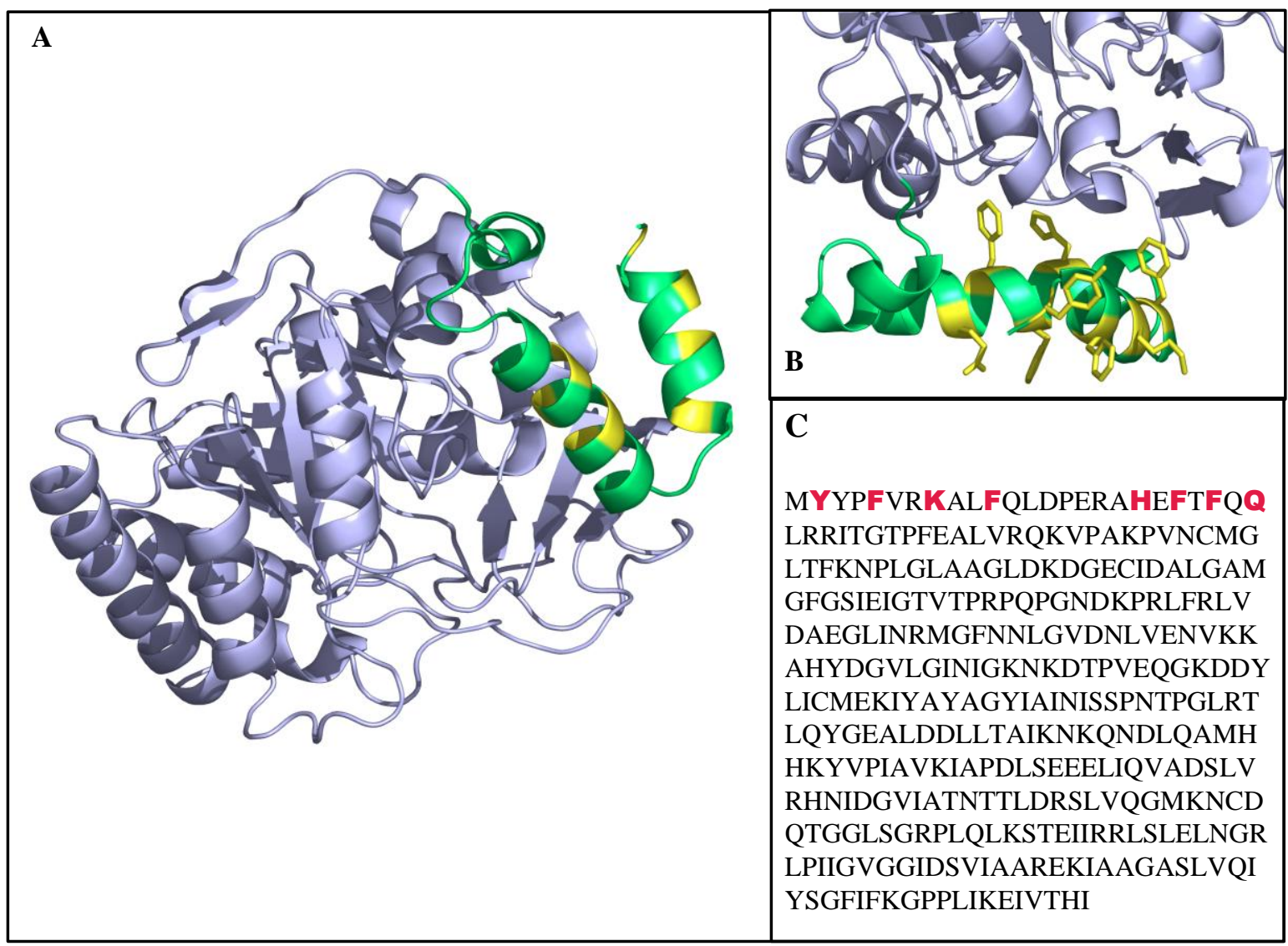

Figura 36 - Estrutura da enzima EcDHODH com destaque para os resíduos trocados por resíduos de císteina no domínio $\mathrm{N}$-terminal. (A) Os resíduos em amarelo e verde ilustram o domínio $\mathrm{N}$-terminal, sendo que os resíduos em amarelo representam os aminoácidos mutados por cisteínas. (B) Mostra uma ampliação do domínio N-terminal (em verde e amarelo), onde os resíduos em amarelo representam os aminoácidos substituídos por cisteínas com suas respectivas cadeias laterais em destaque. (C) Seqüência de aminoácidos da EcDHODH, os aminoácidos em vermelho referem-se aos 8 resíduos mutados isoladamente para resíduos de cisteínas. 


\subsubsection{Clonagem dos mutantes da EcDHODH}

As mutações no gene pyrD foram introduzidas através da técnica de PCR, utilizando-se como molde o plasmideo pAG1. Para isso, 17 oligonucleotideos, com tamanhos variando de 21 a 44 bases, foram sintetizados. Os fragmentos de DNAs, onde as mutações foram incorporadas a seqüência da proteína, foram amplificados com sucesso, como mostrado na Figura 38.

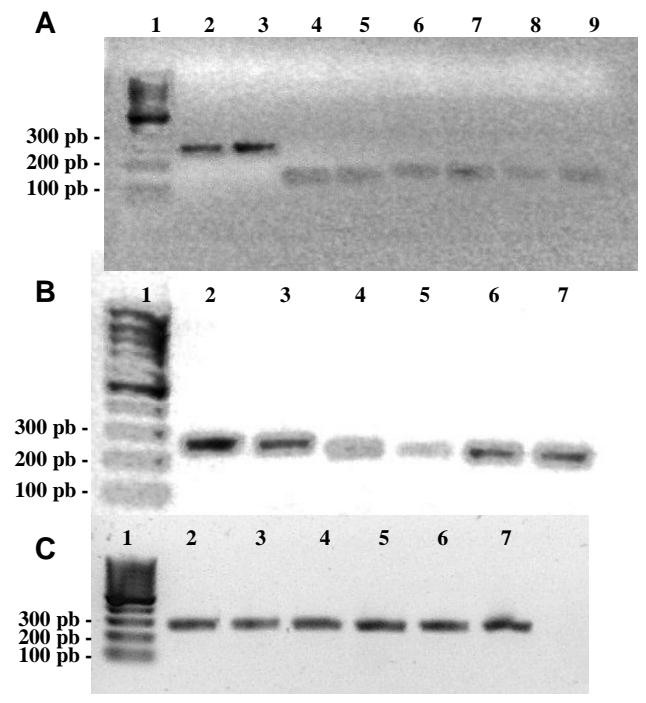

Figura 37 - Produção dos fragmentos sintéticos codificantes das versões mutadas de EcDHODH: análise por eletroforese em gel de agarose 1\%, TAE, corado com brometo de etídeo, mostrando. A Coluna 1 é comum a todos os géis (A, B e C), marcador Plus DNA Ladder (Invitrogen). (A) Colunas 2 e 3 bandas de amplificação resultantes das reações de PCR, correspondentes aos fragmentos de DNA que codificam as mutações Y2C e F5C respectivamente. Colunas 4 a 9 e colunas 2 a 7 em (B) referem-se as bandas resultantes da primeira e segunda etapas de amplificação para gerar as mutações K8C, F11C, H19C, F21C, F23C e Q25C respectivamente. (C) DNAs resultantes da segunda estratégia de clonagem para introduzir mutações em EcDHODH, todos os fragmentos são compostos por $280 \mathrm{pb}$ aproximadamente (ver Tabela 4).

Após amplificação, os fragmentos de DNA foram inseridos no plasmídeo de propagação, $\mathrm{pTZ57R/T}$, permitindo a clonagem direta do produto de PCR, e a subseqüente confirmação da integridade das seqüências por seqüenciamento. Os fragmentos que continham a mutação foram transferidos para o plasmideo de expressão pAG1 e a confirmação da clonagem foi realizada por análise do padrão de restrição dos clones, como demonstrado na Figura 38A.

A ligação dos fragmentos mutados em pAG1A também foi confirmada por análise de restrição, Figura 38B. Em todas as fotos de géis observa-se a presença de duas bandas de 
tamanhos distintos, uma superior correspondente ao plasmídeo pAG1 ou pAG1A (aproximadamente 4.415 pares de bases) e outra menor correspondente ao inserto $(\sim 280$ $\mathrm{pb})$.
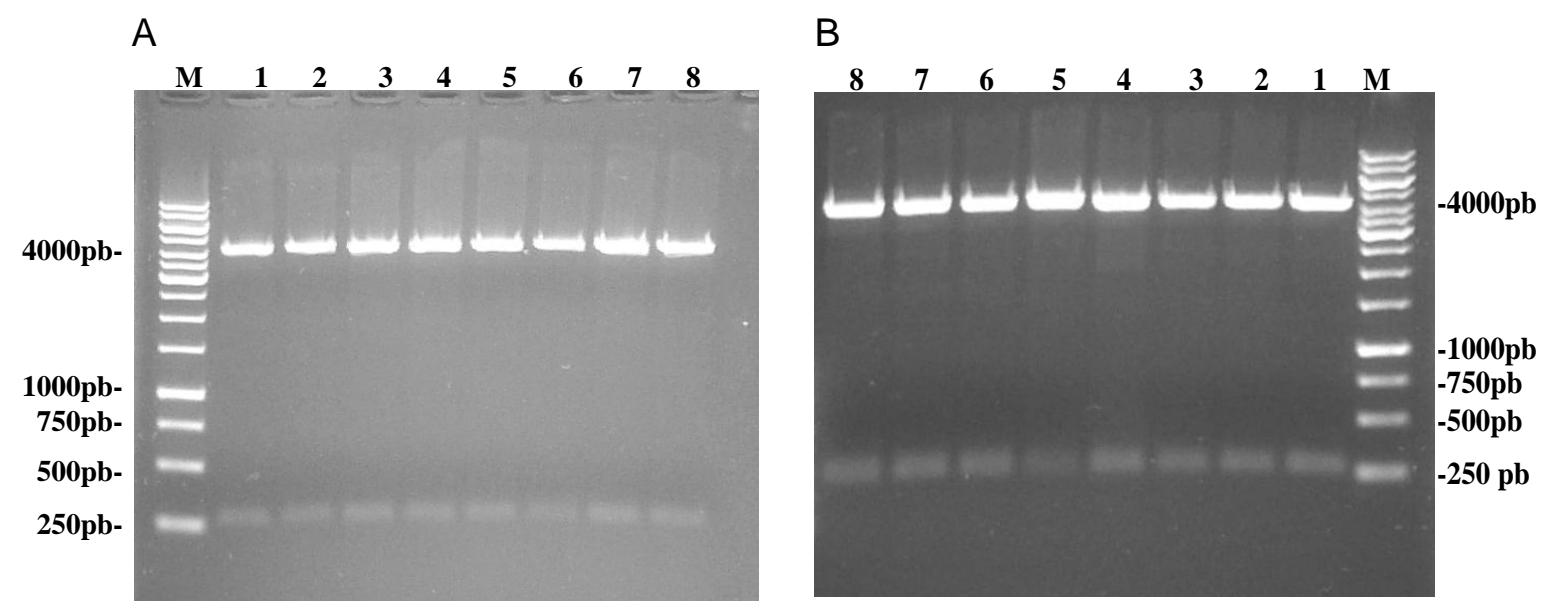

Figura 38 - Padrão de restrição dos clones em pAG1 e pAG1A. As bandas em torno de 280 pares de bases correspondem a seqüência codificadora de cada uma das oito mutações em pAG1 (A) e em pAG1A (B). As bandas superiores nos dois géis correspondem aos vetores pAG1 e pAG1A respectivamente; $M$ corresponde ao padrão em pares de bases. Os DNAs plasmidiais foram clivados com as enzimas EcoRI e Kpnl.

A análise do seqüenciamento das diferentes construções de interesse revelou que as mutações foram inseridas na posição correta da seqüência de nucleotídeos tanto em pAG1 quanto em pAG1A, como pode ser visto pelos resíduos em preto na Figura 40 


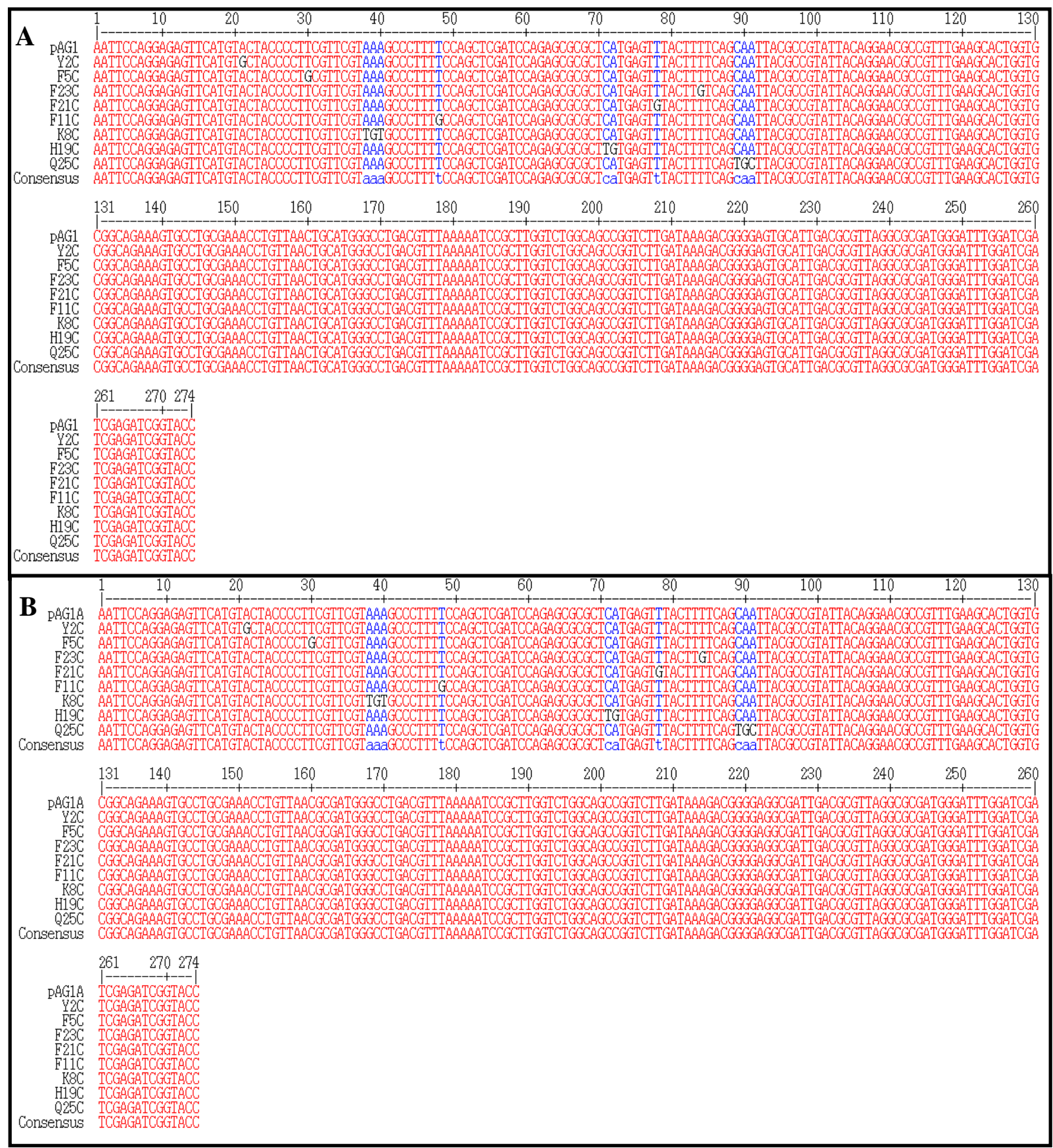

Figura 39 - Alinhamento seqüencial dos primeiros 280 pares de base codificantes da EcDHODH no vetor pAG1 e pAG1A.. Primeiros 280 pares de base da EcDHODH no vetor pAG1 (A) e pAG1A (B) com os fragmentos mutados ( 280 pares de bases). Os nucleotídeos em preto correspondem aos nucleotídeos mutados. Alinhamento feito através do programa Multalin [66].

As seqüências foram analisadas a priori através do programa Gene Runner para identificação do frame de leitura correto e tradução de nucleotídeos para aminoácidos. Posteriormente, foram alinhadas com a seqüência da EcDHODH nos plasmídeos pAG1 e pAG1 $A$ respectivamente, através do programa Multalin [66], Figura 40. 


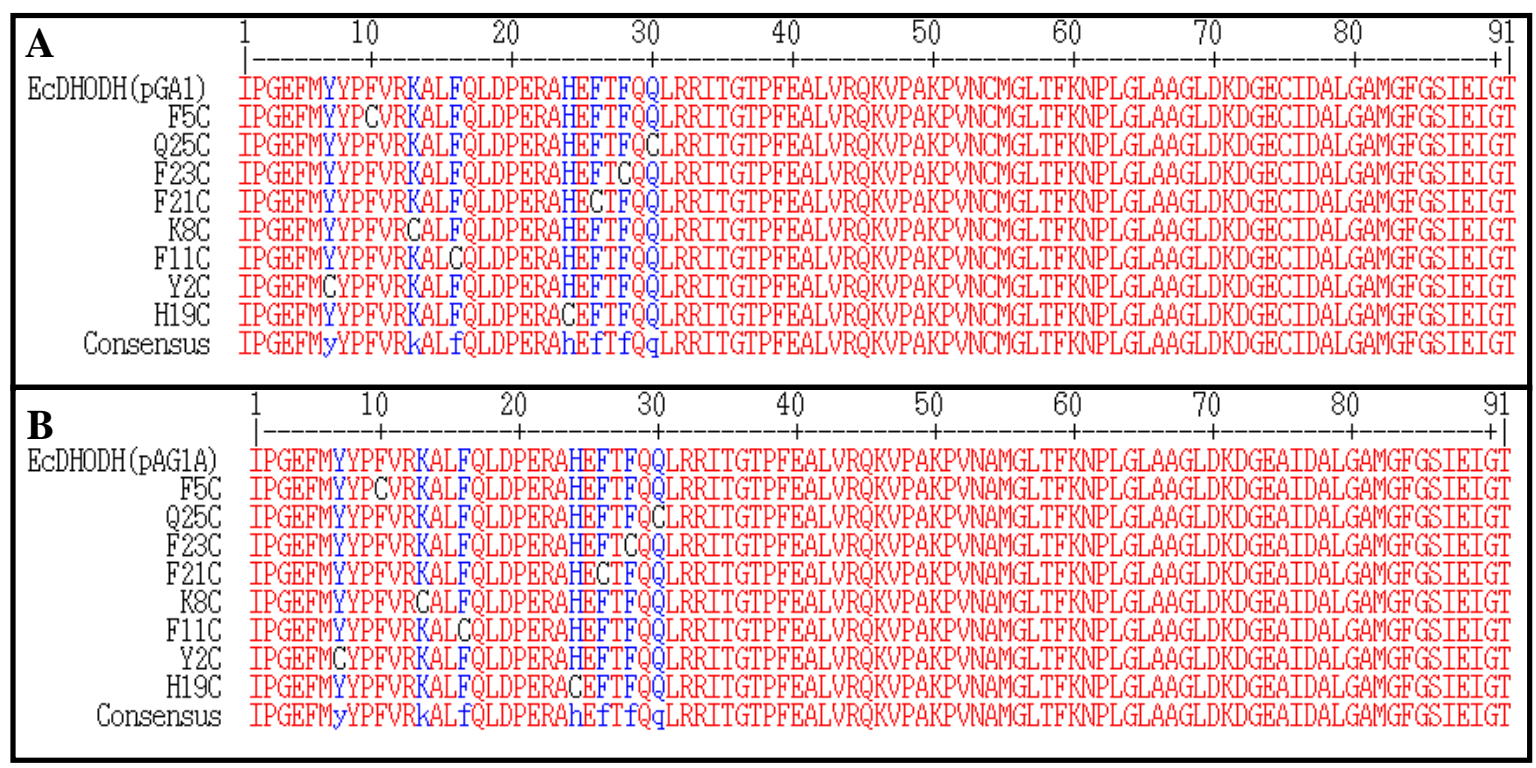

Figura 40 - Seqüência de aminoácidos da enzima EcDHODH em pAG1 e pAG1A alinhada com os fragmentos mutados. (A) EcDHODH/pAG1 e (B) e EcDHODH/pAG1A. O alinhamento foi feito através do programa Multalin [66]. Os resíduos em preto referem-se a cisteínas introduzidas na seqüência nativa.

\subsubsection{Expressão dos mutantes de EcDHODH}

A propagação das construções dos mutantes, assim como a expressão heteróloga desses genes, foi feita em células de E. coli linhagem S06740. As construções no vetor pAG1 permitiram a expressão dos genes mutados sob o controle do promotor lac, $\mathrm{T}_{\mathrm{A} 1 / 04 / 03}$. A expressão gênica foi conduzida pela adição de IPTG, como descrito para a enzima nativa. O nível de expressão das enzimas mutantes foi avaliado por SDS-PAGE (Figura 42). 


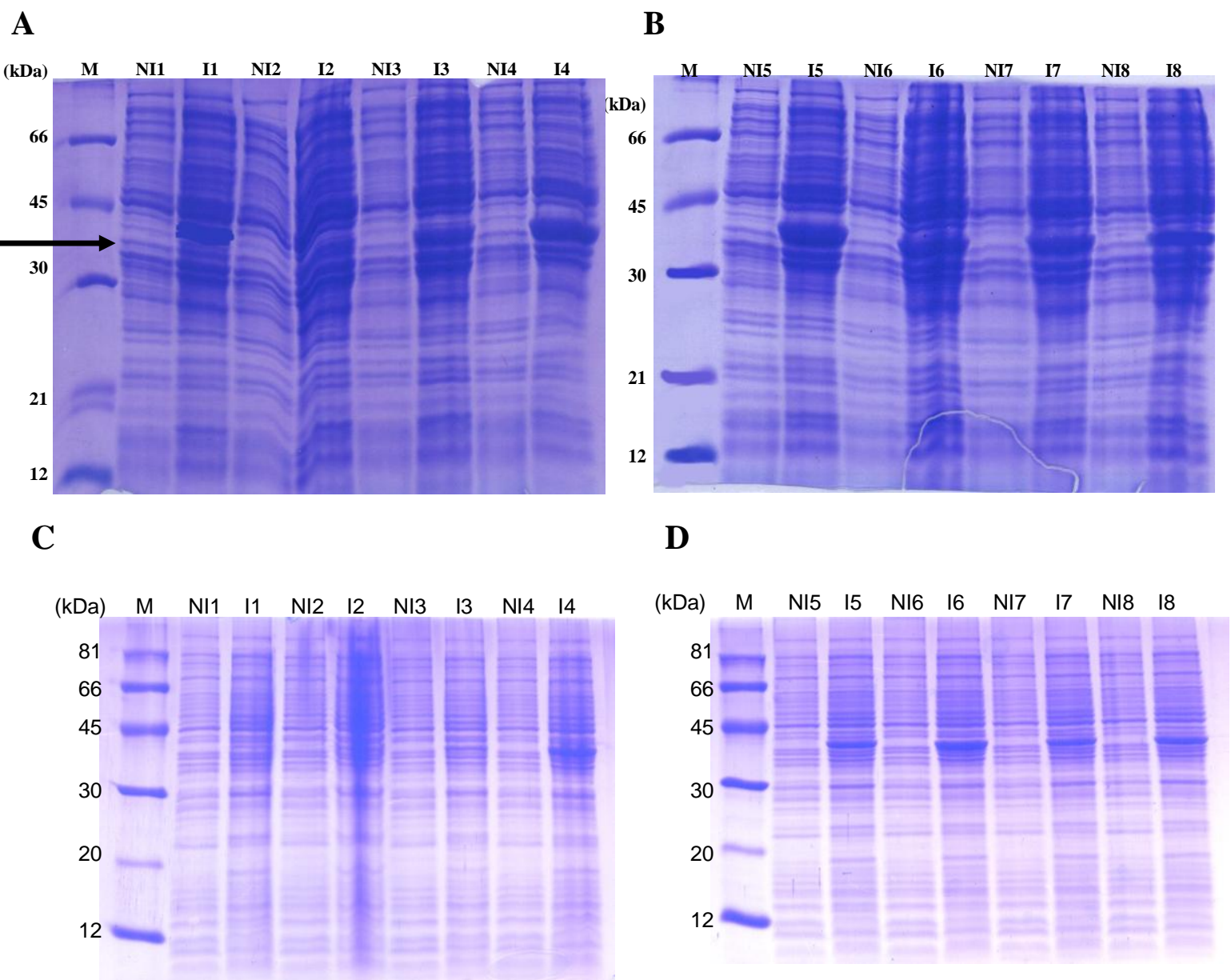

Figura 41 - Análise em SDS-PAGE 15\% da expressão dos mutantes da enzima EcDHODH. M corresponde ao padrão de massa em $\mathrm{kDa}$. Indução da expressão $(250 \mathrm{~mL}) \mathrm{com} 750 \mu \mathrm{M}$ de IPTG a $37^{\circ} \mathrm{C}$ por $12 \mathrm{~h}$. A sigla $\mathrm{NI}$ corresponde as amostras controle - NÃO INDUZIDO enquanto I significa INDUZIDO: A e B referem-se à expressão dos mutantes com resíduos de cisteína nativos preservados, enquanto $C$ e $D$ referem-se à expressão dos mutantes com resíduos de císteina nativos substituídos por resíduos de alanina. (A) e (C) Mutantes 1 a 4 (Tabela 2); (B) e (D) Mutantes 5 a 8 (Tabela 2). A seta indica a banda referente à EcDHODH.

\subsubsection{Purificação da enzima EcDHODH mutada}

As etapas cromatográficas empregadas para promover a purificação dos mutantes para a enzima EcDHODH ocorreram de forma idêntica àquelas padronizadas na purificação da EcDHODH nativa. Para o caso em que os resíduos de cisteína nativos foram mantidos, o nível de pureza obtido foi também alcançado com êxito (Figura 42A). Entretanto, para as construções onde os resíduos de cisteína nativos haviam sido substituídos por resíduos de 
alanina, o protocolo de purificação estabelecido para a proteína nativa não foi suficiente para atingir o nível de pureza esperado, com exceção do mutante F23C, Figura 42B. Diante disto, modificações no protocolo de purificação até então utilizado com sucesso foram introduzidas, tais como: gradientes de sal mais lentos, aumento na quantidade de $\left(\mathrm{NH}_{4}\right)_{2} \mathrm{SO}_{4}$ utilizado na precipitação de contaminantes, adição de DTT durante as etapas cromatográficas, substituição da coluna DEAE-Sepharose pelas colunas CaptoQ (GE Life sciences) e SPFF (GE Life sciences), introdução de uma terceira etapa cromatográfica em coluna de exclusão molecular (SuperDex 200 - GE Life sciences), variação na concentração de detergente Triton X-100 utilizado nas diversas etapas cromatográficas. Todas as modificações introduzidas não demonstraram nenhum sucesso (resultados não mostrados).

A
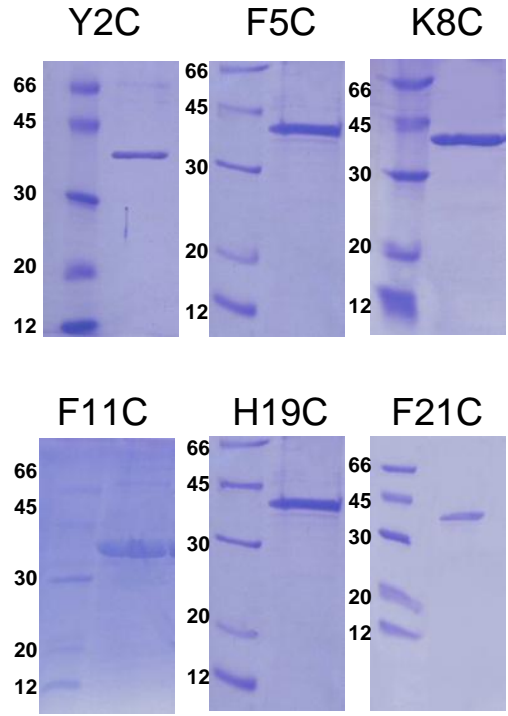

B

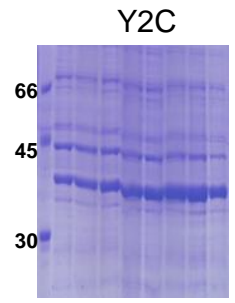

F11C

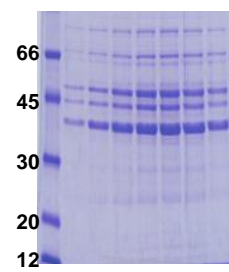

F5C

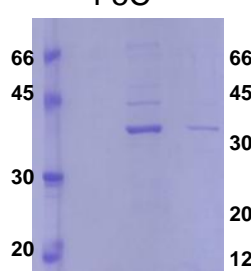

H19C

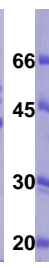

$\mathrm{K} 8 \mathrm{C}$

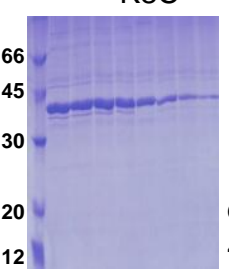

F21C

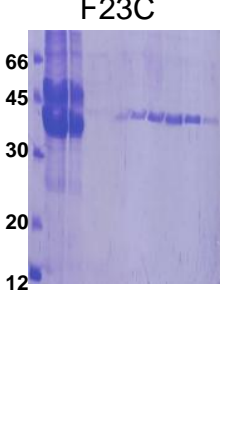

Figura 42 - Analise por eletroforese em SDS-PAGE no nível de pureza dos mutantes de EcDHODH. (A) mutantes de ECDHODH com resíduos nativos de cisteína preservados, todas as frações eluídas da coluna de interação hidrofóbica Phenyl-sepharose apresentam o mesmo padrão de bandas. Na figura apenas uma das frações para cada mutante é mostrada. (B) Mutantes de EcDHODH com resíduos nativos de cisteína trocados por resíduos de alanina. O nível de pureza varia de acordo com a posição da mutação. Para todos os casos em (B) a enzima mutante foi marcada com MTSL antes da etapa de purificação na coluna Phenyl-sepharose. As massas moleculares dos padrões estão em kDa.

O insucesso na purificação dos mutantes de EcDHODH para as construções onde as cisteínas nativas haviam sido substituídas por alaninas pode ser atribuído a pequenas 
variações na conformação e carga líquida da enzima quando comparado com a proteína nativa. No entanto, é importante ressaltar que o monitoramento da atividade catalítica da enzima indica que mesmo que a remoção das cisteínas tenha causado qualquer modificação conformacional, esta não afeta a atividade catalítica da enzima. O mapeamento detalhado do ambiente químico em torno das cisteínas nativas, realizado a partir da análise da estrutura cristalográfica de $\mathrm{EcDHODH}$, mostra que as quatro cisteínas nativas estão livres e localizadas em ambientes hidrofóbicos. Pela análise da estrutura não é possível prever a ruptura de qualquer interação que poderia auxiliar na estabilização da conformação nativa da proteína. Hipóteses como agregação devido ao caráter hidrofóbico da proteína, formação de pontes disulfeto indesejáveis, foram testadas através das diversas modificações no protocolo inicial de purificação, na maioria das vezes sem sucesso. Novos protocolos de purificação estão sendo testados de forma a melhorar o rendimento e o nível de pureza das amostras.

\subsubsection{Análise qualitativa da atividade enzimática dos mutantes de EcDHODH}

A atividade enzimática para os mutantes de EcDHODH foi monitorada segundo o protocolo descrito na seção 4.1 .5 e as curvas de absorção para o DCIP em 610 nm estão mostradas na Figura 43. Todos os mutantes de EcDHODH apresentaram atividade enzimática. Embora as curvas apresentem características diferentes, estas não podem ser associadas a diferenças nas constantes catalíticas. Isto porque, a alta concentração de Triton X-100 nas amostras protéicas inviabiliza uma estimativa precisa da concentração da enzima, de modo que alterações no perfil de redução do DCIP podem estar associadas a diferenças na quantidade de enzima utilizada na realização destes ensaios. Desta forma, os ensaios enzimáticos foram utilizados para avaliar qualitativamente a atividade catalítica da $\mathrm{EcDHODH}$. 
A

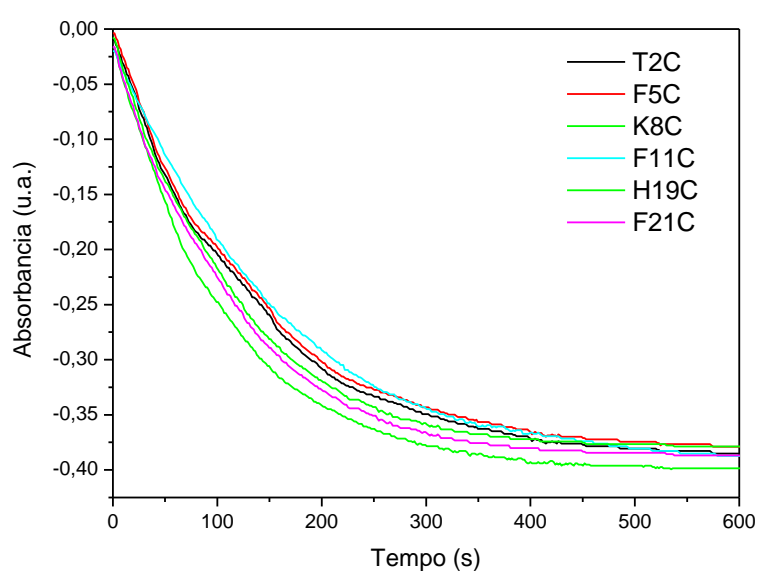

B

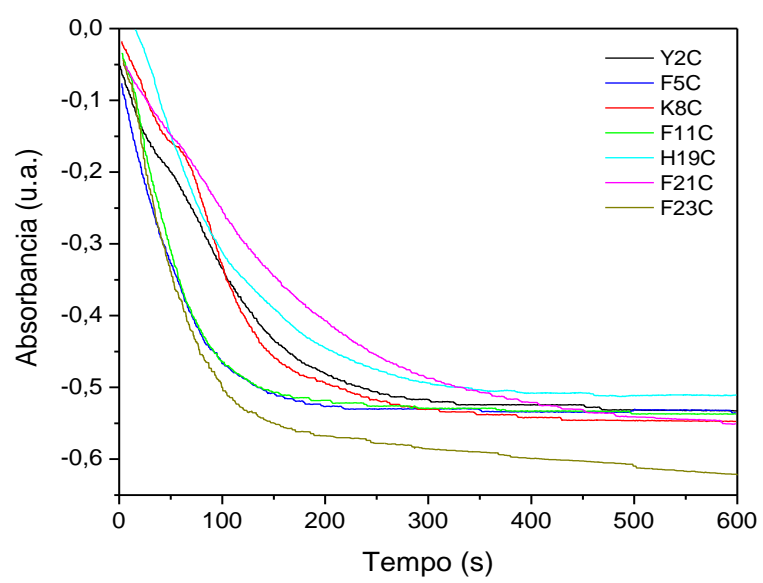

Figura 43 - Atividade enzimática dos mutantes da EcDHODH. (A) monitoramento da redução do DCIP durante a reação catalisada pela $\mathrm{EcDHODH}$ com resíduos de cisteína preservados, mutada em: Y2C, F5C, K8C, F11C, H19C e F21C. (B) monitoramento da redução do DCIP para os mutantes da EcDHODH (Y2C, F5C, K8C, F11C, H19C, F21C e F23C) com resíduos nativos de cisteína substituídos por alanina.

\subsubsection{Dinâmica do marcador de spin em EcDHODH}

A estratégia da SDSL envolve a introdução de um radical nitróxido em uma posição específica da proteína e uma mutação sítio dirigida é normalmente usada para esse fim, sendo um resíduo nativo trocado por um de cisteína, para a posterior reação do seu grupo sulfidrílico com um marcador de spin adequado. O reagente metanotiosulfonato tem sido o mais utilizado para fins de SDSL, embora outros tipos também já tenham sido empregados, Figura $44[37,55]$. 
(a)

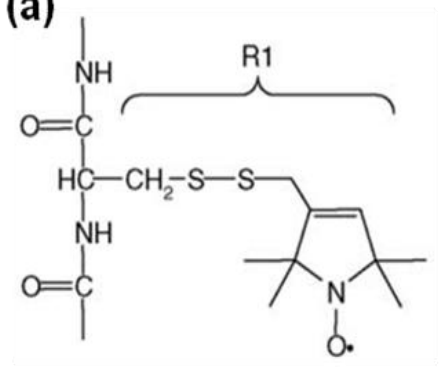

(c)
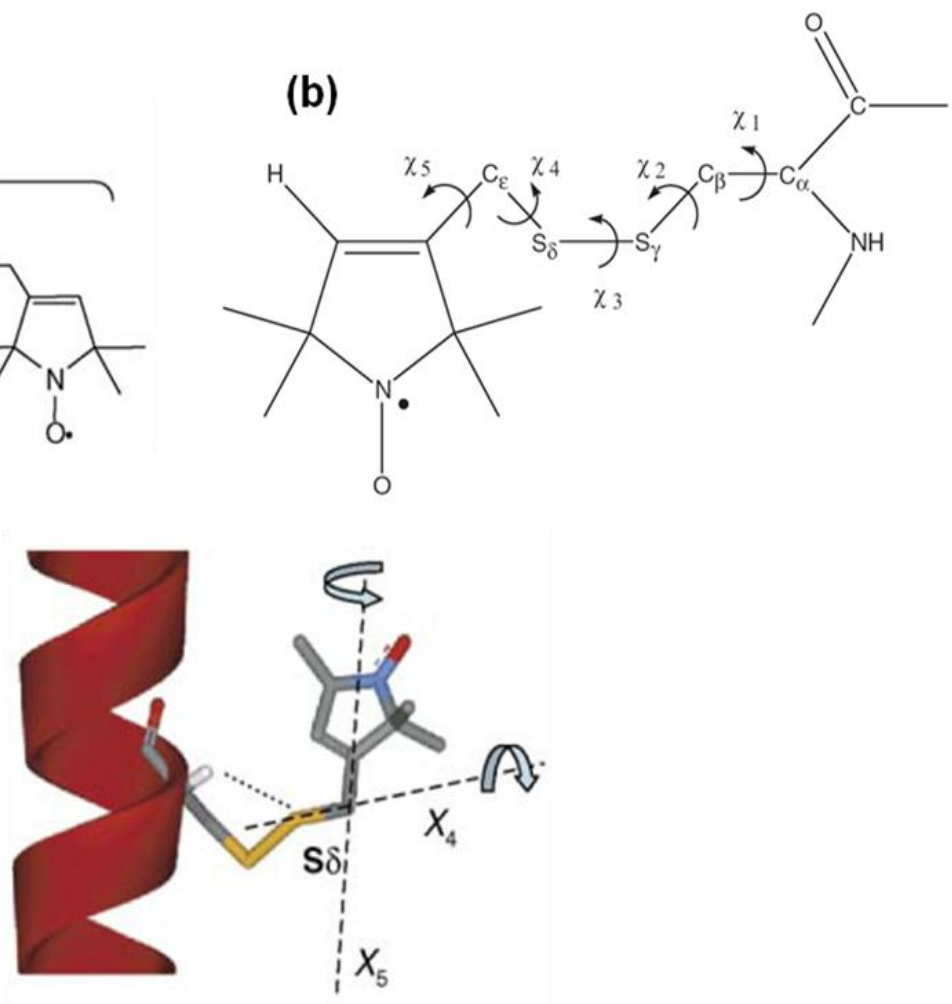

Figura 44 - Estrutura química do radical nitróxido. (a) Estrutura do radical R1 resultante da ligação do marcador de spin metanotiosulfonato (MTSL) a um resíduo de cisteína livre. (b) Estrutura da cadeia lateral R1 indicando os ângulos diédricos $\chi_{1}$ a $\chi_{5}$. (c) Estrutura da cadeia lateral R1 localizada em resíduo na superfície de hélice $\alpha$. Está conformação indica que rotações moleculares são feitas em torno dos ângulos diédricos $\chi_{4} \mathrm{e} \chi_{5}$. As linhas pontilhadas indicam os eixos em torno dos quais essas rotações ocorrem. Figura adaptada das referências 88 e 55.

Informações fundamentais a respeito do sistema de interesse podem ser obtidas por SDSL através da forma da linha espectral. O movimento da cadeia lateral contendo o radical nitróxido é refletido no espectro de RPE através dessa forma de linha e é, basicamente, o resultado da superposição de três movimentos executados pela estrutura protéica. A esses três movimentos podemos associar três tempos de correlação característicos: (1) $\tau_{R}, 0$ tempo de correlação rotacional da proteína inteira ("tumbling”); (2) $\tau_{\mathrm{B}}$, o tempo de correlação devido a isomerizações rotacionais em torno das ligações que conectam o nitróxido à cadeia principal da proteína e (3) $\tau_{s}$, o tempo de correlação associado ao movimento local do segmento da cadeia principal onde está o nitróxido em relação à estrutura da média da proteína. Esses movimentos são pensados como sendo aproximadamente independentes para pequenas flutuações locais do segmento de cadeia principal. Os tempos de correlação 
$\tau_{B}$ e $\tau_{S}$ são aqueles que carregam as informações buscadas por SDSL, pois respondem pelo que podemos chamar de movimento interno da cadeia lateral.

O tempo de correlação rotacional da proteína como um todo $\tau_{\mathrm{R}}$ é uma constante para as cadeias laterais de todos os resíduos na estrutura da proteína nativa. A contribuição desse movimento para o espectro de RPE é pequena no caso de proteínas de massa molecular elevada ou pode ser reduzida, no caso de estruturas pequenas, através do artifício de se fazer as medidas de RPE em solvente contendo, por exemplo, $30 \%$ de sacarose (aumento da viscosidade do meio). Em ambos os casos, o "tumbling" da proteína se torna lento com $\tau_{R}$ maior do que $\tau_{B}$ e $\tau_{S}$. Este é o limite ideal de trabalho já que interessanos não o movimento de "tumbling" da proteína inteira, mas sim flutuações locais de sua cadeia principal. Movimentos muito rápidos como os encontrados em situações opostas às descritas podem levar a uma promediação extensa dos tensores magnéticos, levando à perda da informação acerca da dinâmica local.

O tempo de correlação para isomerização das ligações, $\tau_{B}$, deve depender tanto da estrutura do marcador de spin (tamanho da cadeia lateral), quanto das estruturas primária, secundária e terciária da proteína, ao passo que $\tau_{S}$ é determinado pela flexibilidade do segmento de cadeia principal em estudo.

Rotações da cadeia lateral R1 acontecem em torno das ligações entre o grupo N-O e a cadeia principal (Figura 44B). Essas ligações formam ângulos arbitrários entre si, o que torna muito difícil o ajuste dos espectros experimentais aos modelos usualmente empregados em simulação espectral, já que estes envolvem, em geral, movimentos em torno de eixos mutuamente ortogonais. Sendo assim, devido à complexidade do problema estrutural, simulações espectrais detalhadas como aquelas apresentadas anteriormente no presente trabalho acabam se tornando inviáveis do ponto de vista prático. Uma descrição semiquantitativa acabou por tornar-se comum para análise dos espectros obtidos e que permite interpretar os dados experimentais em termos da relação mobilidade da cadeia lateral e estrutura protéica. O termo mobilidade é usado com um significado mais geral para 
incluir efeitos de ordenamento molecular e taxa de movimento. Assim, um estado de baixa mobilidade pode se dever tanto a uma situação de movimento de grande amplitude e baixa taxa de difusão quanto a um movimento restrito executado com alta freqüência.

A descrição semiquantitativa envolve uma análise da dinâmica experimentada pela cadeia lateral R1 nos sítios de interesse da proteína. Esta dinâmica se reflete na forma de linha do espectro de RPE de uma maneira dependente da estrutura local experimentada pela sonda paramagnética. A relação entre estrutura local e dinâmica pode ser resumida pelos espectros típicos mostrados na Figura 45. Neste caso, os espectros se referem ao marcador MTSL em regiões de loop, de superfície de hélice, de contatos terciários e sítios enterrados na estrutura da lisozima T4 [89]. A classe englobando sítios em contatos terciários é a que possui maior grau de heterogeneidade no que diz respeito à forma de linha dos espectros e mobilidade da cadeia lateral porque tanto o grau de contatos estéricos quanto a mobilidade da cadeia principal mudam com a posição do sítio. Neste ponto, cabe definir o que entendemos por sítios em contatos terciários (ou sítios em interações terciárias) como sendo sítios nos quais, a substituição com a cadeia R1 cria conflitos estereoquímicos com átomos das cadeias laterais ou da cadeia principal de resíduos adjacentes na estrutura tridimensional [89,90]. Portanto, sítios envolvidos em contatos terciários podem apresentar espectros que variam desde aqueles obtidos para sítios enterrados até espectros vistos para sítios em superfícies de hélices. A Figura 45 mostra, portanto, como medidas de RPE podem distinguir a dinâmica de diferentes elementos de estrutura secundária. 


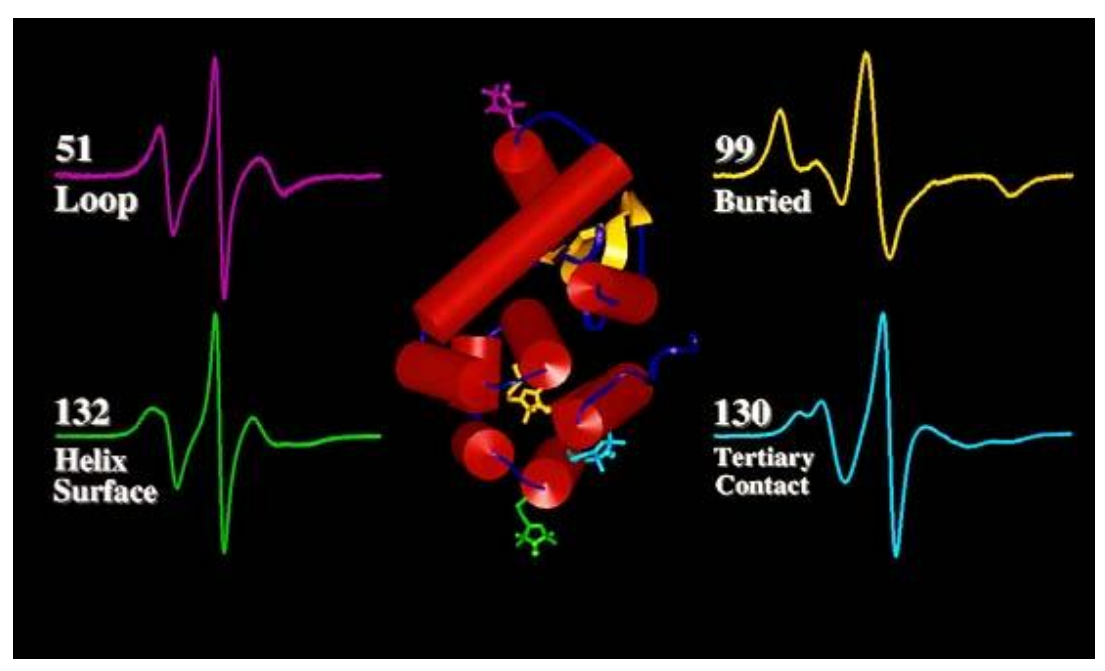

Figura 45 - Mudanças na forma de linha de RPE em função da estrutura local onde se encontra o marcador de spin. Figura adaptada da referência 90.

\subsection{EcDHODH com resíduos nativos de cisteína preservados}

Os espectros do marcador de spin MTSL em diferentes posições ao longo do domínio N-terminal da EcDHODH com os resíduos nativos de cisteína preservados estão mostrados na Figura 46A. Todos os espectros são compostos por mais de uma componente, o que pode ter origem em dois fatores: 1) duas conformações diferentes experimentadas pela cadeia lateral $\mathbf{R} \mathbf{1}$ do marcador em uma determinada posição da cadeia polipeptídica ou 2) marcação de mais de um sítio, já que além do resíduo de cisteína introduzido por mutação sítio dirigida existem outros quatro resíduos de cisteína nativos disponíveis para ligação com o grupo sulfidrila do marcador MTSL (Figura 46B), sendo que pelo menos dois deles, Cys48 e Cys260, encontram-se em regiões da proteína que podem ser facilmente acessadas pelo marcador. Para averiguarmos a qual dos dois motivos se devia o espectro multicomponente obtido, procedemos com a marcação da enzima EcDHODH nativa (sem introdução de nenhuma mutação sítio dirigida), cujo espectro, mostrado na primeira linha da Figura 46A, e que corresponde ao espectro de linhas mais estreitas observado nos espectros dos mutantes, evidencia, portanto, que uma das componentes observadas nos espectros de cada mutante medido se deve realmente à 
marcação de algum dos resíduos nativos de cisteína. As conclusões alcançadas após esses experimentos e com base também nos resultados de seqüenciamento apresentados acima são: a) os resíduos introduzidos por mutação sítio dirigida foram corretamente marcados, já que percebe-se claramente a existência de uma segunda componente em todos os espectros dos mutantes (setas na Figura 46) e que apresenta caráter mais imobilizado do que a componente espectral "nativa", ou seja, logramos sucesso e realizamos os primeiros experimentos de marcação de spin sítio dirigida do Brasil, e b) constatamos que para prosseguirmos com nossos estudos teríamos que voltar à Biologia Molecular e proceder com nova clonagem, desta feita para retirada dos resíduos nativos de cisteína. Esta etapa foi feita como descrito nas seções anteriores.

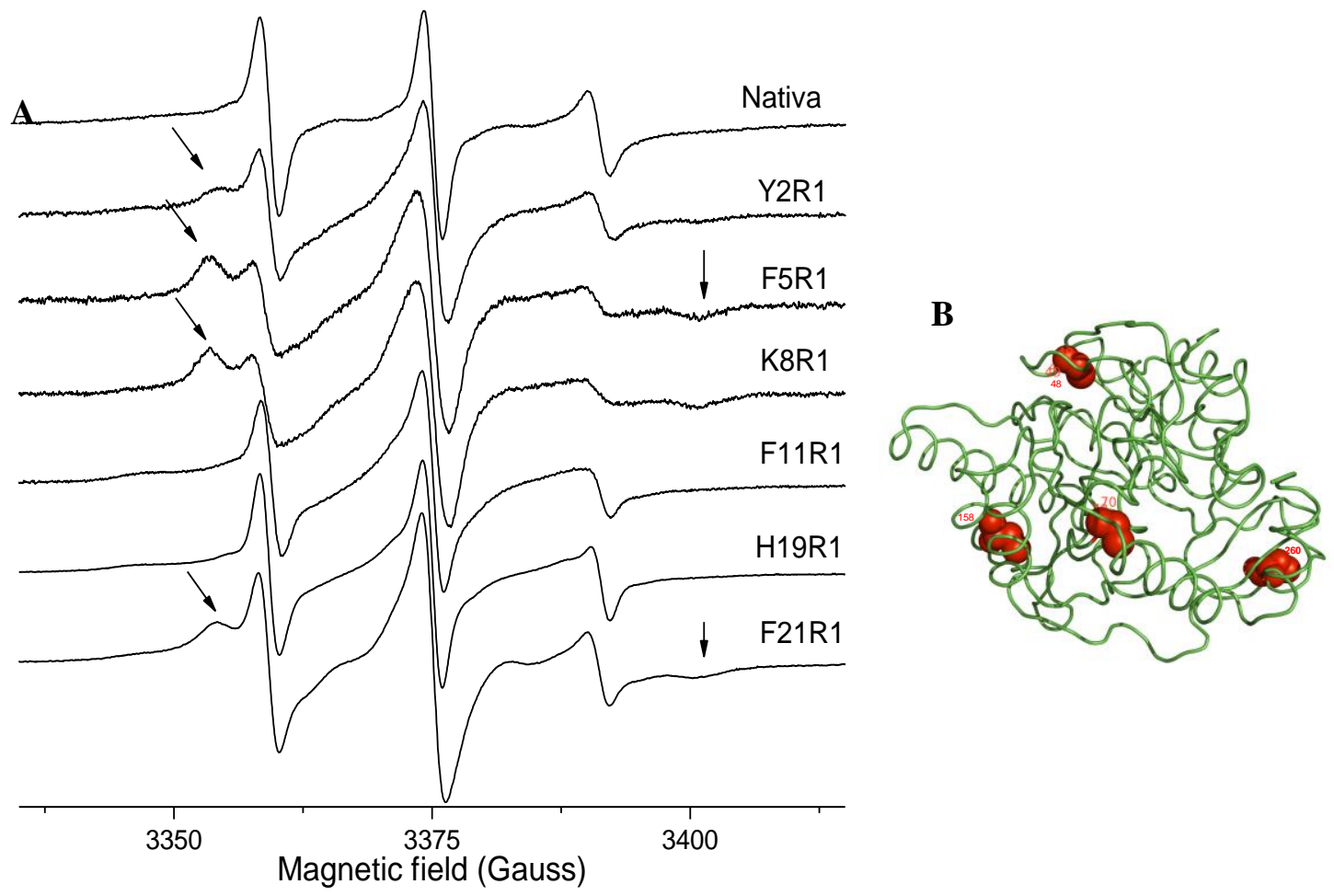

Figura 46 - Espectros de RPE do marcador MTSL incorporado à enzima EcDHODH. (A) espectros de RPE da enzima nativa e dos mutantes Y2R1, F5R1, K8R1, F11R1, H19R1 e F21R1. (B) Resíduos nativos de cisteína (Cys48, Cys70, Cys158 e Cys260) destacados em vermelho (esferas) na estrutura tridimensional da EcDHODH. 
Ainda com os mutantes que conservavam as cisteínas nativas, decidimos realizar um experimento para averiguarmos o papel do detergente no estado de oligomerização da proteína. Assim, retiramos o detergente do mutante F5R1 com o uso da resina calbiosorb (v. seção 4.1.6), medimos seu espectro de RPE e readicionamos o detergente para nova medida de RPE. A remoção do detergente causa mudanças significativas no espectro de RPE, como pode ser observado na Figura 47 (linha vermelha), levando a uma imobilização maior de ambas as componentes espectrais anteriormente observadas (Figura 46). Este é um indicio de que o estado de oligomerização da EcDHODH deve ser mediado pelo domínio N-terminal como observado por Björnberg et al. [19]. Além disso, a readição do detergente à amostra não foi suficiente para desfazer o estado de agregação da enzima (Figura 47 - linha preta), deixando o espectro de RPE inalterado.

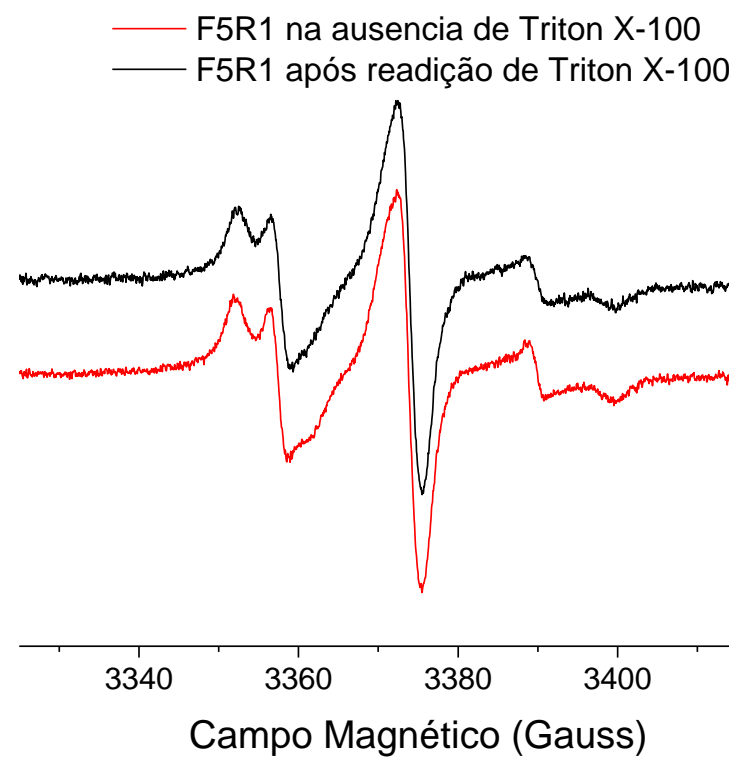

Figura 47 - Espectros de RPE do mutante F5C de EcDHODH marcado com R1. Na ausência de Triton X-100 (linha vermelha) e após a readição de Triton X-100 (linha preta).

\subsection{EcDHODH com resíduos de cisteína nativos substituídos por resíduos de alanina}

Como os resultados de SDSL obtidos para a EcDHODH com os resíduos nativos de cisteína preservados não puderam ser totalmente conclusivos, optamos por preparar novos 
mutantes de EcDHODH onde os resíduos nativos de cisteína fossem substituídos por resíduos de alanina. A opção pelo resíduo alanina se fez devido ao fato desse aminoácido ser pouco reativo, além de possuir cadeia lateral curta, o que não deve perturbar significativamente a estabilidade da proteína do ponto de vista termodinâmico e conformacional (seu diagrama de Ramachandran pode ser assumido como representativo para qualquer outro aminoácido, à exceção da glicina e prolina).

Dos mutantes inicialmente utilizados, apenas quatro puderam ser purificados de forma conveniente após a remoção dos resíduos nativos de cisteína. Assim, um total de quatro posições da cadeia lateral R1 foram analisadas no presente trabalho: duas delas na região inicial da cadeia (Y2R1 e F5R1) e duas delas na segunda hélice da extensão $\mathrm{N}$ terminal (H19R1 e F21R1). A Figura 48 apresenta os espectros de RPE obtidos para o marcador MTSL nas posições dos resíduos nativos Y2, F5, H19 e F21, juntamente com a posição de cada resíduo na estrutura da EcDHODH. 

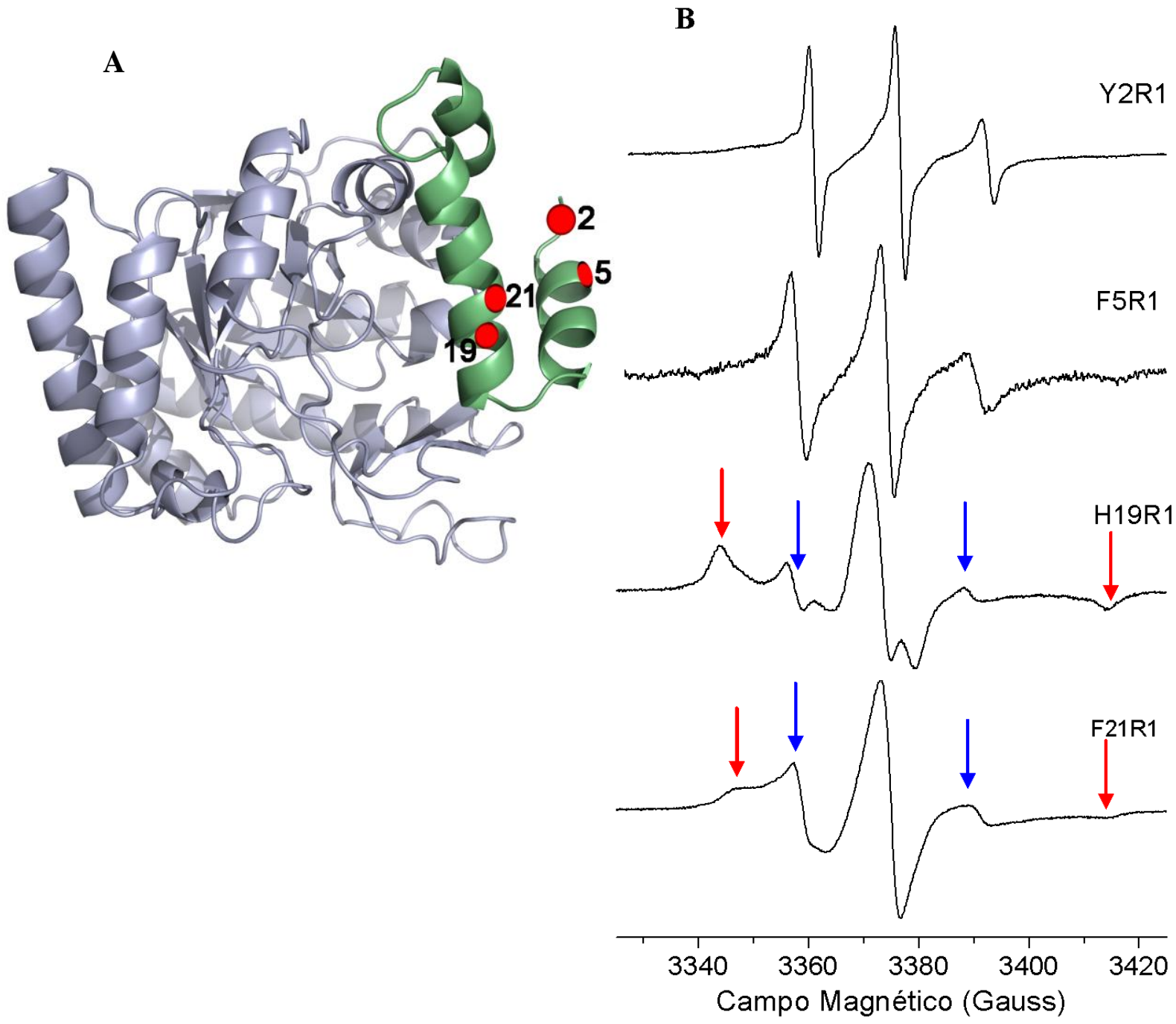

Figura 48 - Espectros de RPE para os mutantes de EcDHODH sem os resíduos nativos de cisteína em vesículas mistas de DOPC/Triton X-100. Espectros do marcador MTSL ligado a cisteínas inseridas nas posições dos resíduos nativos Y2, F5, H19 e F21. Os espectros foram normalizados para áreas iguais.

Os espectros de RPE mostrados na Figura 48 para os mutantes Y2R1 e F5R1 são típicos de espécies com alta mobilidade. $O$ aumento de mobilidade observado provavelmente se deve a uma combinação de dois fatores: 1) uma redução dos impedimentos estereoquímicos das rotações em torno da ligação $\mathrm{C}_{\alpha}-\mathrm{C}_{\beta}$ (ângulo diédrico $\chi_{1}$ - Figura 44) para regiões de loops ou de início/fim da cadeia polipeptídica (neste caso, os resíduos estão bem no começo da seqüência), onde existe pouco ou nenhum contato terciário (v. definição de contato terciário na seção inicial sobre SDSL) da cadeia lateral com 
outras partes da estrutura e 2) grandes flutuações da cadeia principal (backbone). A forma de linha do espectro do mutante Y2R1 apresenta mobilidade maior quando comparada com a do mutante F5R1. Isto se deve ao fato do resíduo de cisteína na posição 2 estar bem no começo da cadeia, onde é experimentada maior liberdade de movimento. O mutante F5R1 tem espectro típico de um resíduo em loop ou na primeira volta de hélice [90] sem contatos. A Figura 49 está em bom acordo com os altos fatores de temperatura, em média $50 \AA^{2}$, obtidos para os resíduos nativos Y2 e F5 na estrutura cristalográfica da EcDHODH (código PDB: 1F76 - v. fatores de temperatura no Apêndice A).

O espectro do mutante H19R1 (Figura 48) apresenta características de um sítio envolvido em contatos terciários, com duas componentes bem definidas, sendo uma majoritária e bastante imobilizada (setas vermelhas na Figura 48B) e outra com movimento rápido (setas azuis na Figura 48B). O aspecto que nos permite assinalar o espectro de H19R1 a um sítio em contatos terciários e não a um sítio enterrado (buried), é a presença dessa componente com pouca restrição de movimento. Em um sítio enterrado, a imobilização do marcador de spin é muito alta com baixa ou nenhuma acessibilidade ao solvente, o que não permite a existência de componentes de movimento rápido. Neste tipo de sítio, os espectros apresentam uma única componente que possui tempo de correlação dominado pela contribuição associada ao movimento de tumbling da proteína $\left(\tau_{\mathrm{R}}\right)$.

Ainda na Figura 48, podemos ver que o mutante F21R1, que está localizado no meio da segunda hélice que compõe a extensão $\mathrm{N}$-terminal da EcDHODH (Figura 49A), apresenta espectro característico de um sítio em contato terciário ou de um sítio em superfície de hélice, mas com duas componentes bem resolvidas, uma correspondente a uma população de menor (setas vermelhas na Figura 48B) e outra de maior mobilidade (setas azuis na Figura 48B), assim como observado para H19R1. A estrutura da EcDHODH mostra que o resíduo nativo F21 encontra-se em uma região de superfície de hélice (Figura 48A). Sendo assim, no caso de F21R1, a observação de duas componentes em seu espectro de SDSL-RPE poderia ser tomado como algo de certo modo surpreendente, pois a julgar pela conformação observada para o resíduo nativo na estrutura da EcDHODH (Figura 
48A), a cadeia lateral deveria experimentar movimento com nenhuma ou muito pouca restrição (sítio exposto em hélice).

Guo et al. [91] obtiveram espectros similares para os sítios expostos T115, N116, R119 e Q122 da lisozima T4. Com base na estrutura cristalográfica do mutante T115R1, Guo et al. racionalizaram detalhadamente as razões para o aparecimento de um espectro multicomponente para sítios que deveriam experimentar pouca ou nenhuma restrição de movimento.

Aminoácidos nativos podem assumir diferentes conformações (rotâmeros), isto é, suas cadeias laterais podem ser representadas por certo número de combinações dos ângulos torsionais $\chi$ (Figura 44). Os valores preferenciais de $\chi_{1}$ e $\chi_{2}$ (rotâmeros) para cadeias laterais alifáticas não-ramificadas e que possuem um átomo $\delta$ estão mostrados na Figura 49 [92], juntamente com os rotâmeros para cisteína. Estruturas cristalográficas disponíveis para vários mutantes contendo a cadeia lateral R1 [91,93] mostram que esta cadeia lateral, assim como os aminoácidos naturais, também é rotamérica mesmo quando introduzida em sítios expostos e com baixa restrição estrutural.

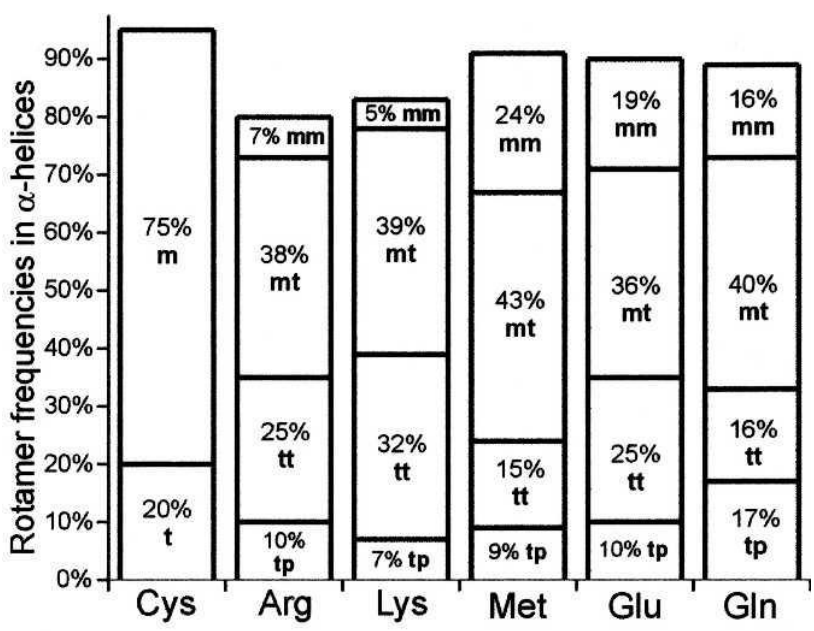

Figura 49: Ângulos torsionais preferenciais para cadeias laterais nativas de cisteína e outras cadeias alifáticas e não-ramificadas. A nomenclatura adotada para os rotâmeros segue a convenção para ângulos diédricos definida no trabalho de Lovell et al. [92], pela qual nominalmente $m$ (minus) $=-60^{\circ}, \mathrm{p}$ (positive) $=+60^{\circ}$ e t (trans) $= \pm 180^{\circ}$. Na prática, os ângulos $\chi_{1}$ e $\chi_{2}$ podem diferir consideravelmente desses valore, mas a notação simplificada é mantida. Pares como mt referem-se aos valores de $\chi_{1}$ e $\chi_{2}$, respectivamente. Figura adaptada da referência 91. 
No modelo estrutural mais aceito até o momento para a descrição da dinâmica da cadeia lateral $\mathrm{R} 1$ em sítios expostos em hélices, o átomo $\mathrm{S}_{\delta}$ da ponte dissulfeto (Figura 44B) interage com átomos da cadeia principal de duas maneiras que originam os dois rotâmeros: atração putativa $\mathrm{S}_{\delta} \cdots \mathrm{HC}_{\alpha}[93,94]$ e interação do mesmo $\mathrm{S}_{\delta}$ com o grupo $\mathrm{C}=\mathrm{O}$ do resíduo e com o átomo de $\mathrm{N}$ do resíduo subseqüente $[95,96)$. Essas interações limitam as rotações em torno dos ângulos $\chi_{1}$ e $\chi_{2}$. Como a isomerização da ponte dissulfeto (ângulo $\chi_{3}$ - Figura 44B) envolve uma barreira energética alta de cerca de $7 \mathrm{kcal} / \mathrm{mol}[97,98]$, rotações em torno de $\chi_{3}$ também ficam restringidas. Assim, torções em torno de $\chi_{4}$ e $\chi_{5}$ (Figura $44 C$ ) devem dominar o movimento do radical nitróxido.

As interações com átomos da cadeia principal descritas acima são responsáveis pela estabilização dos dois rotâmeros com relação aos ângulos diédricos $\chi_{1}$ e $\chi_{2}$. Porém, interações adicionais do anel do nitróxido são necessárias para modular de forma diferente o movimento do radical nos dois rotâmeros, assim dando origem a espectros de RPE multicomponentes. Guo et al. [91] mostraram que uma contribuição que parece diferenciar os dois rotâmeros é a interação hidrofóbica do anel no rotâmero em que temos $\mathrm{S}_{\delta} \cdots \mathrm{HC}_{\alpha}$. Neste rotâmero, estudos de modelagem para o sítio 115 da lisozima T4 sugerem que o anel do nitróxido se projeta na direção de um bolso hidrofóbico adjacente, ao passo que o segundo rotâmero estaria mais sujeito a interação com o resíduo i+4, originando, assim, dois modos diferenciados de movimentação do marcador de spin MTSL.

O modelo apresentado serve para explicar a existência de duas componentes espectrais em sítios como F21R1 (Figura 48B), que não pareceria experimentar restrições consideráveis de movimento que justificassem o aparecimento de duas componentes, sendo uma delas com mobilidade reduzida. Outro fator que deve contribuir para o aparecimento de duas componentes no caso de F21R1 de EcDHODH é a existência de um meio anisotrópico em que se insere a região do N-terminal constituído pelas moléculas anfipáticas de detergente e/ou fosfolipídio. 
O modelo acima, também conhecido como modelo $\chi_{4} / \chi_{5}$, pode, ainda, ser estendido ao sítio H19R1. Neste último caso, o resíduo 19 está claramente envolvido em contatos terciários que levam a uma imobilização mais acentuada de um dos rotâmeros (Figura 48) do que aquela observada para F21R1. Além disso, a existência de uma conformação pouco imobilizada para o resíduo H19R1 sugere que a hélice em que tal resíduo se encontra não deva ser tão rígida quanto se poderia supor a partir da estrutura cristalográfica de EcDHODH. Os fatores de temperatura dos átomos do resíduo nativo H19 (v. Apêndice A) estão em torno de $20 \AA^{2}$, o que levaria a acreditar em baixa flexibilidade desse resíduo. No entanto, os espectros de SDSL-RPE apontam claramente para uma mobilidade desse resíduo contrastante com aquele inferida da estrutura tridimensional da proteína. Com o resíduo H19R1 experimentando uma dinâmica menos restrita, como se depreende dos espectros acima, os dois rotâmeros distintos da cadeia lateral R1 poderiam se formar em uma região com volume livre disponível para difusão rotacional apenas médio.

Uma análise conjunta dos espectros dos quatro mutantes apresentados (Figura 48) e levando-se em conta modelos estruturais como o descrito acima, podemos perceber o grau de detalhes a que se pode chegar a partir de estudos sistemáticos de regiões diversas em proteínas como a EcDHODH. Assim, a dinâmica experimentada pela região do N-terminal parece ser, em linhas gerais, maior do que poderia se presumir com base exclusivamente nos fatores de temperatura oriundos da estrutura cristalográfica de EcDHODH. Esta diferença pode estar ligada ao fato de, na estrutura determinada para a proteína, existirem quatro moléculas na unidade assimétrica, com os contatos intermoleculares mediados exatamente pela região do $\mathrm{N}$-terminal, levando, portanto, a uma restrição de flexibilidade para alguns resíduos que não seria observada quando da proteína em seu ambiente nativo. Os dados de SDSL-RPE sugerem, então, maior mobilidade do domínio N-terminal, o que deve estar associado provavelmente com o seu papel durante o processo de atividade enzimática, no qual se requer que tal região participe da ligação dos aceptores de elétrons envolvidos na segunda metade da reação de oxi-redução catalisada pela EcDHODH. 


\section{Diidroorotato Desidrogenase de Xylella fastidiosa}




\section{Diidroorotato Desidrogenase de Xylella fastidiosa}

Em 1987, uma nova doença de citros, clorose variegada dos citros (CVC), foi identificada em pomares do Triângulo Mineiro e do Norte e Nordeste do estado de São Paulo. Conhecida popularmente como "Praga do Amarelinho", foi disseminada rapidamente no Brasil, onde causa perdas na produção de citros que, segundo estimativas no ano de 2000 foram superiores a 650 milhões de reais $[99,100]$.

Causada pela bactéria Xylella fastidiosa, a doença é caracterizada por manchas cloróticas amarelas que surgem nas folhas de plantas afetadas (Figura 50A). Os frutos são muito menores que os normais, extremamente duros e sem valor comercial (Figura 50B). Uma vez que a planta está afetada por CVC, a velocidade de crescimento diminui, novos brotos e ramos morrem, e a copa reduz seu tamanho sem, no entanto, causar a morte da planta [101].

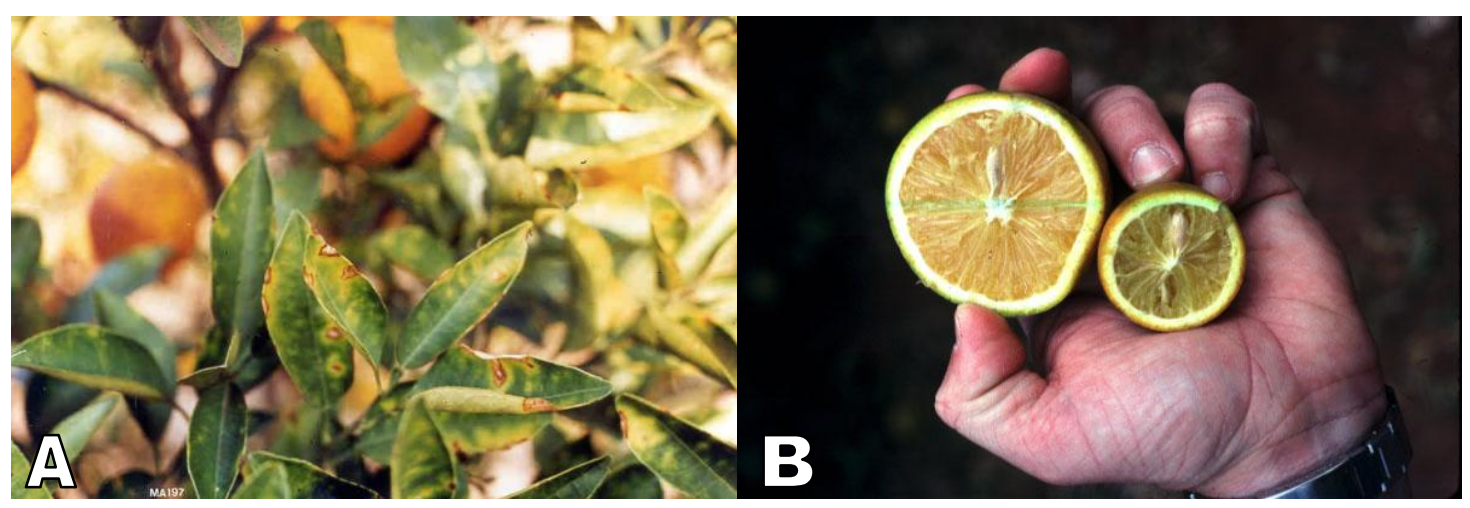

Figura 50 - Sintomas da infecção da planta por CVC. (A) Discoloração nas folhas da planta contaminada com CVC; (B) Laranja sadia em contraste com a laranja contaminada com a doença. Figura fornecida por Alexander Purcell [102].

A bactéria Xylella fastidiosa ataca o xilema, elemento condutor de água nas plantas. A cigarrinha, inseto que se alimenta da seiva do xilema, transmite a bactéria de plantas doentes para plantas saudáveis. As plantas começam a desenvolver os sintomas da doença quando a bactéria bloqueia o sistema condutor de água e reduz o abastecimento nas folhas. 
Existem comprovadamente onze espécies de cigarrinha capazes de transmitir a bactéria Xylella fastidiosa [103].

A CVC afeta a maioria dos tipos de laranja, mas também é encontrada em outros tipos de citrus no Brasil como lima Rangpur, mandarim Cleópatra e limão Volkameriano. Além disso, uma outra linhagem de Xylella fastidiosa é também responsável pela doença de Pierce (PD), que ataca principalmente videiras, pessegueiros e pés de ameixa, sendo encontrada principalmente nas Américas do Norte (sul dos Estados Unidos) e Central [104].

Em julho de 2000, a seqüência completa do genoma da bactéria fitopatogênica Xylella Fastiodiosa foi publicada em um trabalho em conjunto entre vários laboratórios do Estado de São Paulo (Projeto ONSA) [105]. Por ser um dos organismos menos conhecidos que tiveram seu genoma seqüenciado, esse trabalho revelou não somente o tipo de metabolismo básico da bactéria e suas características de replicação, mas também um número de potenciais mecanismos de patogenicidade.

Como descrito, Xylella fastidiosa exibe uma extensa capacidade biosintética, presumidamente uma necessidade obrigatória para bactérias que habitam o xilema. Um exemplo é o caminho biossintético de novo de nucleotídeos de pirimidinas. Xylella fastidiosa contém todas as seis enzimas que participam desta via metabólica (Figura 2), inclusive a Diidroorotato desidrogenase $(\mathrm{XfDHODH})$.

De acordo com sua seqüência primária, XfDHODH pertence à classe 2 das DHODHs, caracterizada pela extensão na região $\mathrm{N}$-terminal, associada à interação da mesma com a membrana bacteriana, o que faz dela uma excelente candidata a estudos pela técnica de "site-directed spin labeling", assim como a EcDHODH.

A enzima XfDHODH apresenta $45 \%$ de identidade seqüencial com DHODH humana e 49\% com a DHODH de E. coli. A maioria dos resíduos envolvidos na interação com FMN e orotato é conservada nas DHODHs de diversos organismos e a DHODH de Xylella fastidiosa não é uma exceção. Uma comparação entre a estrutura primária de XfDHODH, 
EcDHODH e HsDHODH sugere que as enzimas são bastante similares no seu modo de interação com o cofator FMN e com o substrato [Figura 50].

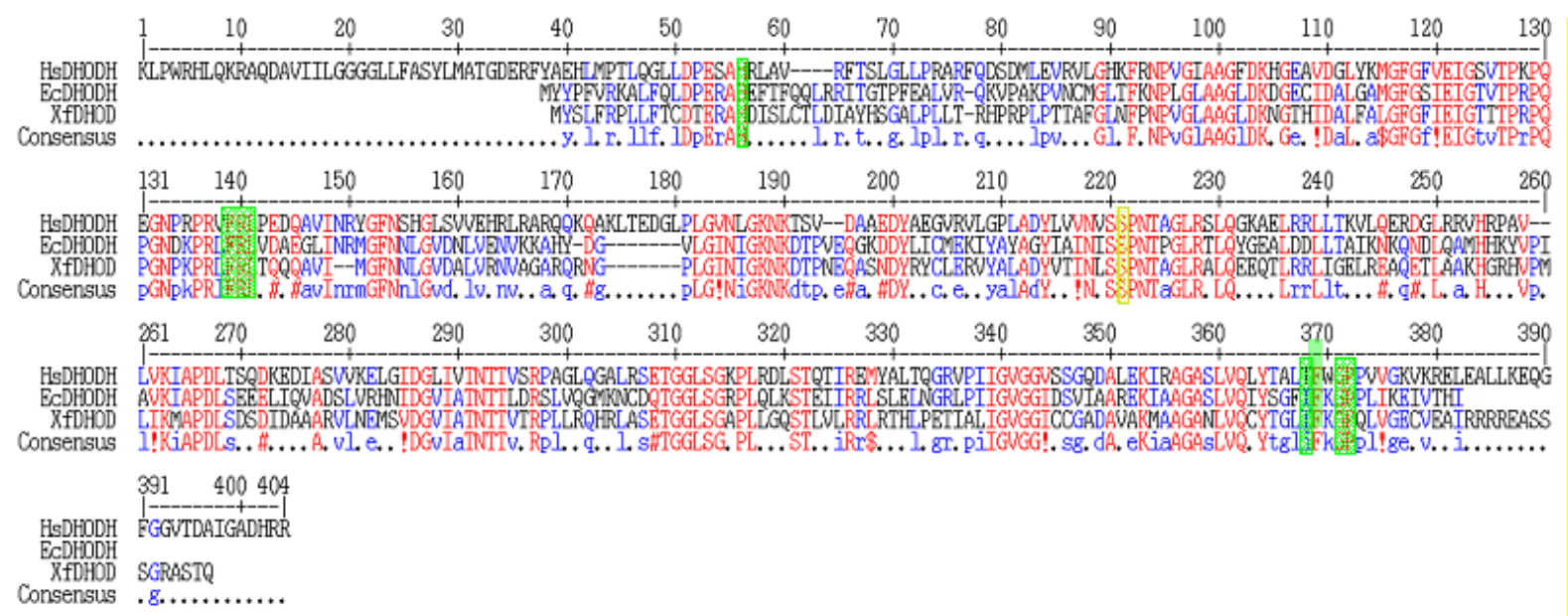

Figura 51 - Alinhamento seqüencial entre a estrutura primária de HsDHODH, EcDHODH e XfDHODH. Em verde, os resíduos da enzima humana envolvidos na ligação com os agentes antiproliferativos brequinar e A771726 que são conservados também nas enzimas bacterianas [21]. A serina catalítica conservada nas três enzimas está destacada em amarelo. Alinhamento realizado utilizando o programa Multalin [66].

Como citado na introdução deste trabalho, a segunda etapa do processo de conversão de diidroorotato em orotato envolve a reciclagem de FMN através da redução de $\mathrm{FMNH}_{2}$ em FMN por intermédio de uma terceira molécula. No caso da enzima humana, ubiquinona é o agente oxidante e a estrutura cristalográfica de HsDHODH revela os resíduos importantes na ligação com os agentes antiproliferativos, brequinar e A771726, e ubiquinona. Dentre estes resíduos, His56, Tyr356, Arg137 e Pro364 são conservados na seqüência de Xylella fastidiosa e Escherichia coli. Gln47 é substituída por leucina, Thr360 por Isoleucina, Met43 por Phenylalanina em XfDHODH e valina em EcDHODH, Ala59 por Serina e Tirosina em XfDHODH e EcDHODH respectivamente e Leu68 é conservada em EcDHODH e substituída por glutamato em XfDHODH (Figura 51) [21].

Até o momento não há nenhuma forma eficaz de combate a CVC. Quando a planta é contaminada pela bactéria, precisa ser derrubada para que a doença não seja transmitida para toda a plantação ou mesmo plantações vizinhas. O entendimento do metabolismo da bactéria Xylella fastidiosa, pode ajudar na busca por alvos para o combate a CVC e a 
$\mathrm{XfDHODH}$ demonstra ser um excelente alvo para a busca de inibidores. Para isso, o conhecimento do seu mecanismo de reação e de como ocorre a interação proteínamembrana se faz necessário.

Como veremos, foi realizado um extenso trabalho na tentativa de se obter a proteína XfDHODH com qualidade e quantidade necessárias para os estudos espectroscópicos propostos. Várias construções foram utilizadas e inúmeros experimentos de expressão e purificação foram realizados, o que consumiu grande parte do tempo de desenvolvimento do projeto de doutorado aqui descrito. No entanto, como veremos, não foi possível obter a enzima XfDHODH em condições adequadas para os nossos experimentos. Por esta razão, as seções de metodologia e resultados e discussões apresentam de forma resumida os experimentos realizados, onde são destacados os melhores resultados obtidos até o presente momento. Vale lembrar que, devido ao grande interesse biotecnológico na enzima XfDHODH, os trabalhos de expressão e purificação da proteína em condições nativas ainda estão em desenvolvimento, agora no Laboratório de Cristalografia de Proteínas da FCFRP/USP.

\subsection{Metodologia}

\subsubsection{Estratégia de Clonagem}

Com o objetivo de expressar em bactéria a enzima DHODH de Xylella fastidiosa $9 a 5 c$, foram sintetizados oligonucleotídeos específicos baseados na seqüência codificante de XfDHODH, depositada no GenBank, sob o número de acesso NP_299848. Os oligonucleotídeos além de flanquearem as seqüência de interesse também possuem sítios para enzimas de restrição que permitem a clonagem nos vetores de expressão testados. No desenvolvimento deste projeto, trabalhamos com três diferentes construções, onde foram 
testados diferentes vetores e dois tamanhos diferentes para o gene. Para as distintas clonagens, o cosmídeo XF 0222, que contém o gene para DHODH da bactéria Xylella fastidiosa foi utilizado como molde para as reações de PCR.

As estratégias de clonagem foram planejadas baseadas no sucesso obtido na clonagem dos genes da DHODH humana [21] e de Plasmodium falcipurum [18], onde foram utilizadas sistemas de fusão com cauda de histidina. Para tanto, utilizamos os vetores de expressão pET28a e pET32a (Novagen) onde o gene que codifica XfDHODH se encontra fusionada a uma seqüência de seis códons para histidinas, utilizadas para facilitar os experimentos de purificação (Figuras 53 e 54). Além disso, no caso específico do vetor de expressão pET32a, o gene que codifica a proteína se encontra também fusionado a uma seqüência que codifica a proteína tioredoxina (Figura 54). Estudos mostram que a presença da tioredoxina pode, muitas vezes, ajudar na solubilização de proteínas e por isto foi utilizado em nossos estudos. Além disso, a análise comparativa das seqüências primárias das DHODHs de diferentes linhagens de Xylella fastidiosa [106] nos sugeriu que a presença de oito aminoácidos na região $\mathrm{N}$-terminal descrita para nossa cepa de interesse (9a5c), poderia ser conseqüência de um erro na notação do gene. Esta análise nos conduziu a também testarmos uma nova construção na qual os códons para os oito primeiros aminoácidos na seqüência primaria da XfDHODH (da cepa de interesse - 9a5c) fossem deletados. Sendo assim, foram testadas neste trabalho as construções: denominadas XfDHODH-pET28a para a expressão da proteína completa em pET28a, e XfDHODHmyspET32a e XfDHODHmys-pET28a para a expressão da proteína onde os 8 primeiros da região $\mathrm{N}$-terminal foi removido. Os trabalhos de clonagem do gene XfDHODH foram realizados no laboratório de Cristalografia de Proteínas da Faculdade de Ciências Farmacêuticas de Ribeirão Preto, sob a supervisão da Profa. Dra. Maria Cristina Nonato. 


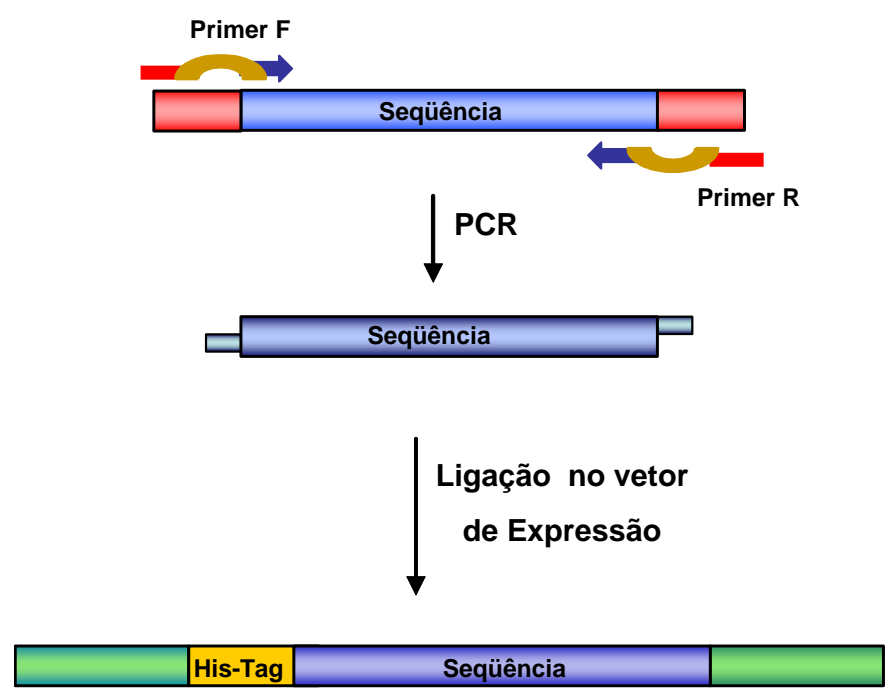

Figura 52 - Esquema ilustrativo da construção em pET28a. Azul, a seqüência de nucleotídeos codificadora de XfDHODH. Amarelo corresponde à seqüência de seis códons para resíduos de histidina. Verde representa a seqüência de nucleotídeos do vetor de expressão Pet28a.

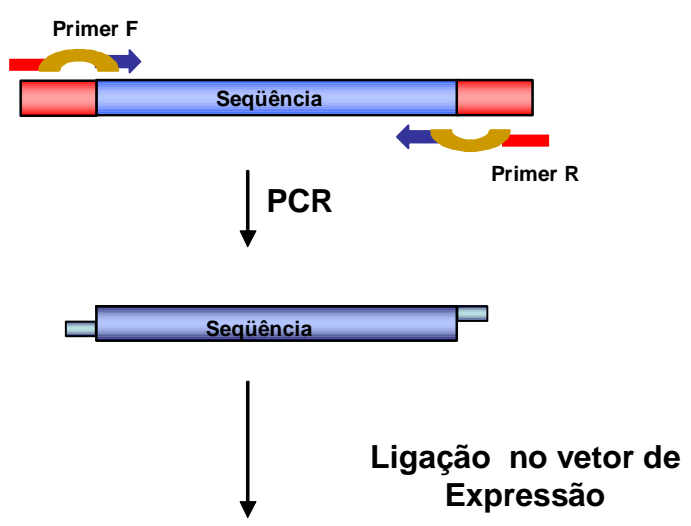

Figura 53 - Esquema ilustrativo da construção em pET32a. Azul, a seqüência de nucleotídeos codificadora de XfDHODH. Amarelo corresponde à seqüência de seis códons para resíduos de histidina. Cor-de-rosa, seqüência de códons para tioredoxina. Verde representa a seqüência de nucleotídeos do vetor de expressão Pet28a.

\subsubsection{Expressão heteróloga da XfDHODH}

Para a construção da enzima em pET28a, XfDHODH-pET28a ,foram realizados inúmeros testes de expressão a fim de obter a enzima XfDHODH em quantidade e solubilidade suficientes para realização de ensaios espectroscópicos, tais como medidas de CD e RPE. Dentre os parâmetros testados, está temperatura de indução, composição do 
meio de cultura e concentração do agente indutor, IPTG. Na Tabela 6 encontra-se mostra como estes parâmetros foram variados.

Tabela 6 - Condições testadas na expressão de XfDHODH em pET28a

\begin{tabular}{ccccc}
\hline Cepa & [IPTG] & Tempo de Indução & Temperatura & Meio de Cultura \\
& $(m M)$ & $(h)$ & $\left({ }^{\circ} \mathrm{C}\right)$ & \\
\hline BL21(DE3) & $0,1,0,5$ e 1 & $2,5,18$ e 24 & $20,25,30$ e 37 & LB, LB rico e LB + FMN \\
\hline
\end{tabular}

Concentração de FMN = $100 \mu \mathrm{M}$.

Para as construções XfDHODHmys-pET28a e XfDHODHmys-pET32a além das várias condições de expressão como temperatura e concentração do agente indutor, diferentes cepas de E. coli foram testadas. Células de E. coli (BL21(DE3), Origami (DE3) e AD494(DE3)) contendo as construções de DNA de interesse foram inoculadas em meio LB, contendo o antibiótico adequado para seleção, e incubadas por $14 \mathrm{~h}$ a $37^{\circ} \mathrm{C}$ e $250 \mathrm{rpm}$. Em seguida os inóculos foram diluídos em meio de cultura apropriado contendo antibiótico, segundo a razão $1: 100$. A cultura foi mantida a sob agitação a $37^{\circ} \mathrm{C}$ até atingir $\mathrm{DO}_{600 \mathrm{~nm}}=$ 0.6-0.8. Em seguida testes de expressão da proteína recombinante foram realizados de acordo com as tabelas 6 e 7. Nos casos onde há FMN adicionado ao meio de cultura, a adição deste, foi feita no momento da indução com IPTG. As células foram coletadas por centrifugação a $10.000 \times \mathrm{g}$ e congeladas a $-20^{\circ} \mathrm{C}$ até o uso.

A partir dos DNAs obtidos com a clonagem do gene codificador de XfDHODH com parte da seqüência deletada (XfDHODHmys), foram realizados vários testes de expressão também com o objetivo de obter a enzima sob a forma solúvel e em quantidades satisfatórias para realização dos ensaios espectroscópicos. Na Tabela 7 estão apresentadas as condições testadas. 
Tabela 7 - Condições testadas na expressão da XfDHODHmys com os oito primeiros aminoácidos deletados.

\begin{tabular}{|c|c|c|c|c|c|}
\hline Cepa & Vetor & $\begin{array}{l}\text { Concentração } \\
\text { de IPTG (mM) }\end{array}$ & $\begin{array}{c}\text { Tempo de } \\
\text { Indução (h) }\end{array}$ & $\begin{array}{c}\text { Temperatura } \\
\left({ }^{\circ} \mathrm{C}\right)\end{array}$ & Meio de Cultura \\
\hline \multirow{5}{*}{$\begin{array}{l}\text { Origami } \\
\text { (DE3) }\end{array}$} & pET32a & $0,005,0,05,0,5$ & $2,4,6$ & 25 & LB \\
\hline & & 0,005 & 48 & 20 & Mínimo (M9) \\
\hline & & 0,005 & 48 & 20 & Mínimo (M9)+FMN \\
\hline & & 0,5 & 25 & 20 & LB \\
\hline & pET28a & $0,05,0,5$ e 1 & $2,4,6$ e 12 & 20 e 25 & LB \\
\hline $\begin{array}{l}A D 494 \\
(D E 3)\end{array}$ & pET32a & $0,005,0,05,0,5$ & 2,6 e 24 & 25 & LB \\
\hline
\end{tabular}

\subsubsection{Purificação da XfDODHmys}

Para os vários protocolos de expressão, o material foi submetido a ensaios de purificação. As células foram descongeladas em banho de gelo e resuspensas no tampão $A$ [ $\mathrm{NaH}_{2} \mathrm{PO}_{4} 50 \mathrm{mM}, \mathrm{NaCl} 300 \mathrm{mM}$, imidazol $5 \mathrm{mM}$ (pH8.0)], contendo $1 \mathrm{mg} / \mathrm{mL}$ de lisozima. O precipitado resuspenso foi incubado por $15 \min$ a $4{ }^{\circ} \mathrm{C}$ e, em seguida, sonicado em um ciclo de 6 vezes por $30 \mathrm{~s}$, com intervalos de $60 \mathrm{~s}$. As frações solúvel e insolúvel foram separadas por centrifugação a 20.000 x g e $4^{\circ} \mathrm{C}$. O sobrenadante foi incubado com a resina de níquel, previamente equilibrada com tampão $\mathrm{A}$, por $30 \mathrm{~min}$ a $4{ }^{\circ} \mathrm{C}$. Após a incubação, a resina foi empacotada em coluna descartável de plástico e o eluato coletado. A coluna foi então lavada 2 vezes com $8 \mathrm{~mL}$ do tampão A contendo imidazol $25 \mathrm{mM}$, a seguir a coluna foi lavada 2 vezes com $8 \mathrm{~mL}$ do Tampão A contendo imidazol $50 \mathrm{mM}$ e mais 2 vezes com $8 \mathrm{~mL}$ do mesmo tampão contendo imidazol 100 mM. A eluição foi feita em volumes de $1 \mathrm{~mL}$ com o tampão de eluição $\left[\mathrm{NaH}_{2} \mathrm{PO}_{4} 50 \mathrm{mM}, \mathrm{NaCl} 300 \mathrm{mM}\right.$, imidazol $\left.250 \mathrm{mM}(\mathrm{pH} 8,0)\right]$. As frações obtidas durante o processo de purificação foram analisadas em SDS-PAGE 15\%. 
Nos experimentos onde inibidores de proteases foram utilizados as concentrações usadas foram: aprotinina $10 \mu \mathrm{g} / \mathrm{mL}$, PMSF $1 \mathrm{mM}$, pepstatina $10 \mu \mathrm{M}$ e leupeptina $50 \mu \mathrm{M}$. Os inibidores foram adicionados ao tampão de resuspensão das células e mantidos nos tampões de purificação. Nos experimentos onde detergentes foram utilizados as concentrações variaram de 0,1 a $1 \%(\mathrm{v} / \mathrm{v})$. E a adição destes foi feita no tampão de resuspensão.

\subsection{Resultados e Discussões}

\subsubsection{Expressão e Solubilidade da enzima XfDHODH nas construções XfDHODH-pet28a e XfDHODHmys-pet28a}

Embora diferentes condições, tais como, temperatura, concentração do indutor e tempo de indução, tenham sido testadas com a finalidade de produzir a enzima XfDHODH sob a forma solúvel em bactéria BL21(DE3), nenhuma atingiu o sucesso esperado. Em todas as condições testadas o nível de expressão foi razoavelmente alto, entretanto, a enzima se encontrava insolúvel para todas as condições avaliadas, sugerindo a formação de corpos de inclusão. Como exemplo, a Figura 54, mostra o resultado do teste cuja expressão foi induzida a $20^{\circ} \mathrm{C}$ por $6 \mathrm{~h}$ pela adição de $0,5 \mathrm{mM}$ de IPTG.

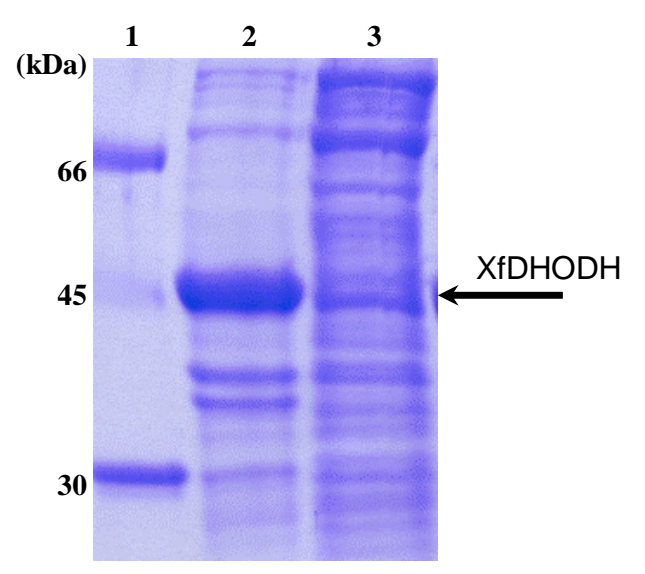

Figura 54 - Expressão da XfDHODH avaliada por eletroforese em SDS-PAGE. Coluna 1, padrão de massa molecular em kDa; Coluna 2, fração insolúvel após rompimento das células; Coluna 3, fração solúvel após rompimento das células. A seta indica a presença da banda correspondente a $\mathrm{XfDHODH}$. 
Apesar de a Figura 54, apresentar apenas o resultado para um dos testes aplicados, os resultados obtidos com os demais testes foram muito similares. $O$ insucesso na solubilização da XfDHODH observado em todos os testes realizados conduz a hipótese de que a proteína é expressa na forma de corpos de inclusão.

\subsubsection{Análise seqüencial}

Recentemente, a seqüência da enzima DHODH de diferentes linhagens de Xylella fastidiosa foi disponibilizadas no banco de dados de seqüências, NCBI [106]. Uma análise da seqüência primária destas proteínas revelou que a linhagem 9a5c, responsável pela praga do amarelinho, apresentava uma extensão $\mathrm{N}$-terminal constituída de oito resíduos de aminoácidos (Figura 55). Isto nos levou a questionamento da seqüência genômica utilizada inicialmente, neste trabalho, para clonar e expressar a enzima XfDHODH. Todas as outras linhagens de Xylella fastidiosa (Temecula 1, Ann-1 e Dixon) possuem uma região Nterminal $100 \%$ conservada e que se inicia com a seqüência MYS (metionina, tirosina, serina). Além disso, a enzima $\mathrm{DHODH}$ da bactéria de $E$. coli também apresenta uma seqüência N-terminal mais curta que a XfDHODH da cepa 9a5c, como observado para as diferentes cepas de Xylella fastidiosa. A similaridade seqüencial entre os resíduos de XfDHODH e os resíduos que participam da interação com a membrana em células de E. coli [22] sustentam a hipótese que esta extensão N-terminal descrita para a cepa 9a5c de Xylella fastidiosa, provavelmente não existe, pois se existisse não participaria do domínio de interação com a membrana. 


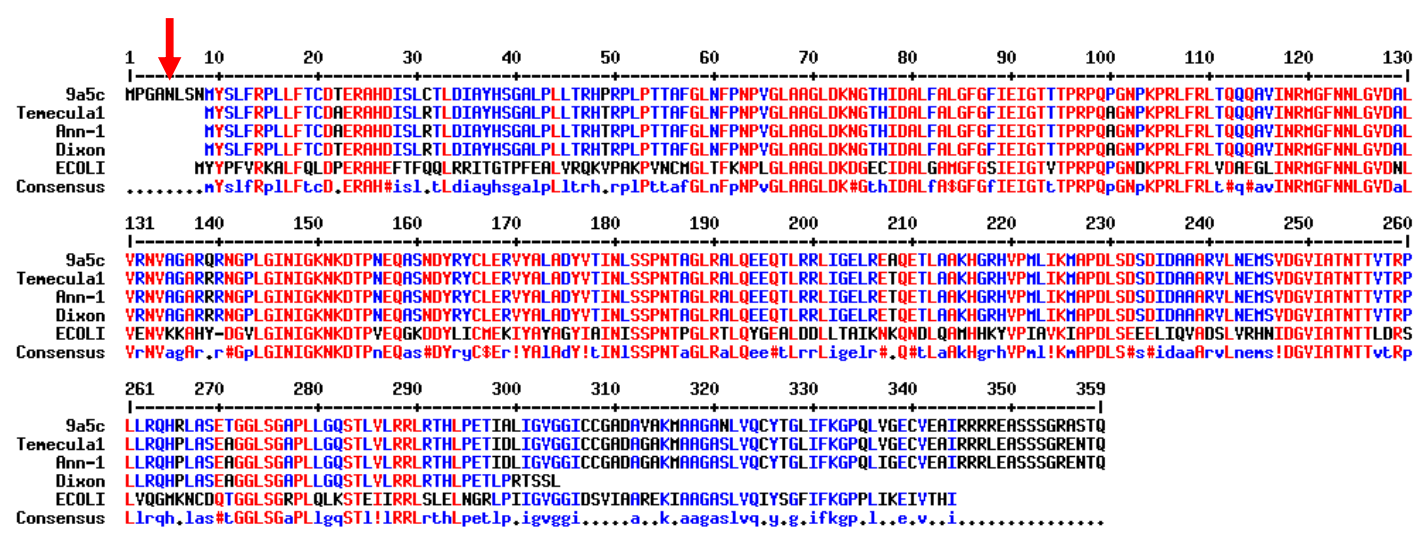

Figura 55 - Alinhamento da enzima DHODH de várias cepas da bactéria Xylella fastidiosa e da DHODH de E. coli. O alinhamento foi feito através do software multalin [66]. Os resíduos em vermelho são conservados nas seqüências de todos os organismos, os resíduos em azul são parcialmente conservados e os aminoácidos em preto não são conservados.

\subsubsection{Expressão e solubilidade da enzima XfDHODHmys-pet32a}

Foram realizados ensaios de expressão e purificação para as construções XfDHODH-pet28a e XfDHODHmys-pet28a sem sucesso. Como testado e relatado para a construção apresentada na seção 5.2.1, foram testadas diferentes temperaturas, concentração do indutor, além da adição de detergentes durante e após o rompimento das células, todas sem sucesso. Para estas construções, embora o nível de expressão seja bastante alto, a enzima se encontra insolúvel sugerindo mais uma vez a formação de corpos de inclusão insolúveis, inadequada para os propósitos deste trabalho. Entretanto, os resultados obtidos com a construção XfDHODHmys-pET32a em origami(DE3) foram mais positivos. A presença da fusão com tioredoxina se mostrou importante para a solubilização da enzima (colunas 3 e 5 na Figura 56). Embora a banda referente a fração solúvel seja muito fraca quando comparada a fração insolúvel a solubilidade da enzima foi confirmada pela forte cor amarela característica das DHODHs que possuem FMN como cofator. Como pode ser observado na Figura abaixo, as condições nas quais a enzima foi expressa sob a forma solúvel, foram: $50 \mu \mathrm{M}$ de IPTG com 6 horas de indução e $500 \mu \mathrm{M}$ de IPTG com 2 horas de indução. 


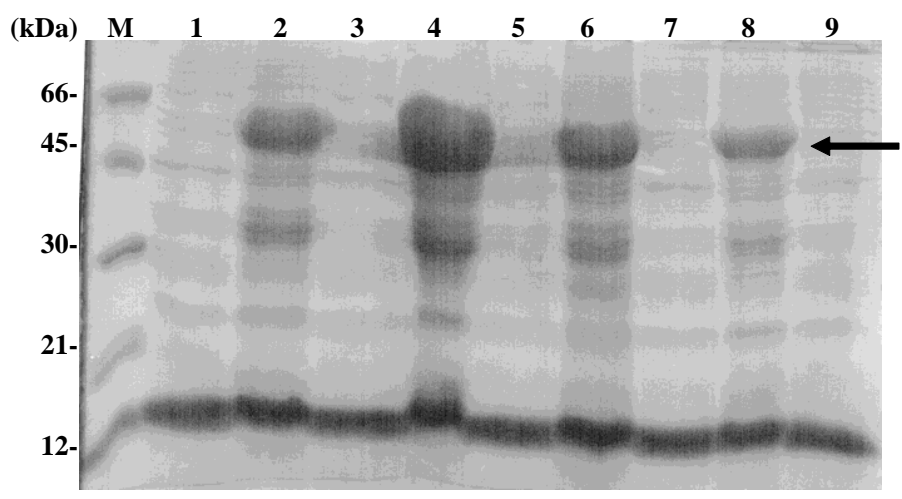

Figura 56 - Resultado da expressão da XfDHODHmys-pET32a. Culturas induzidas a $25^{\circ} \mathrm{C}$ com $50 \mu \mathrm{M}$ de IPTG: sobrenadante colunas 1 (4h) e 3 (6h) e "pellet" colunas 2 (4h) e 4 (6h). Culturas induzidas a $25^{\circ} \mathrm{C}$ com $500 \mu \mathrm{M}$ de IPTG: sobrenadante colunas 5 (2h), 7(4h) e 9 (6h) e "pellet" colunas $6(2 \mathrm{~h})$ e $8(4 \mathrm{~h})$. A seta vermelha indica a banda referente a XfDHODH. A enzima solúvel é observada nas colunas 3 e 5 .

\subsubsection{Purificação da enzima XfDHODHmys sob condições nativas}

O protocolo inicialmente empregado para purificação da XfDHODHmys foi a purificação por afinidade em coluna Ni-NTA. Neste ponto, que a resina de níquel de cor azul ficou verde após a aplicação com a proteína, de cor amarela, indicando que houve a interação (íons de níquel)-(XfDHODH).

A eficiência da purificação foi avaliada em gel SDS-PAGE 15\%, como mostra a Figura 57. Como pode ser observado, grande quantidade da enzima na forma solúvel foi obtida, entretanto o nível de pureza parece ser muito baixo. No entanto, através uma análise mais cuidadosa sugere que as várias bandas observadas no gel não são proteínas contaminantes, mas sim efeitos da degradação da XfDHODHmys, pois nas frações referentes a eluição da enzima surgem bandas (por exemplo em $20 \mathrm{kDa}$ ) inexistentes nas frações iniciais (sobrenadante e eluato), indicando que a proteína degrada durante o processo de purificação. A susceptibilidade da proteína DHODH a forte degradação já havia sido reportada [18]. 
A

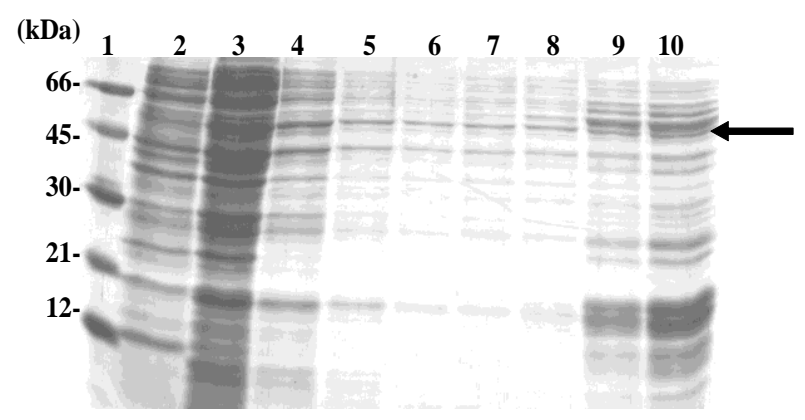

B

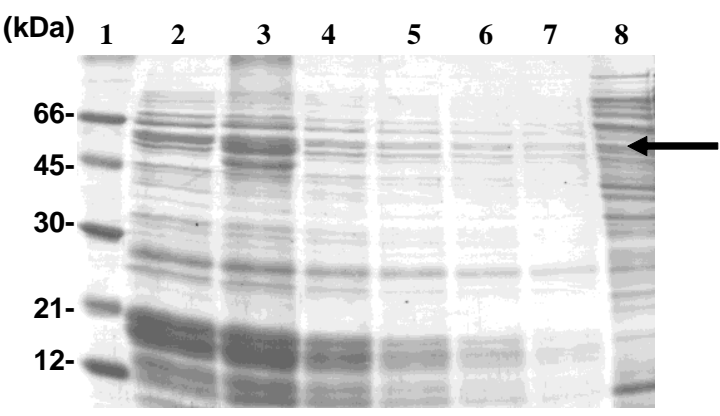

Figura 57 - Resultado da purificação da XfDHODHmys apresentado em SDS-PAGE. Colunas 1 em ambos os géis, marcador da massa molecular em $\mathrm{kDa}$. Colunas 1 a 5 referem-se às lavagens com $25 \mathrm{mM}, 50 \mathrm{mM}$ e $100 \mathrm{mM}$ de imidazol respectivamente; Colunas 6 a 9 em (a) e 1 a 6 em (b) referem-se às frações eluídas com $250 \mathrm{mM}$ de imidazol; Coluna $7 \mathrm{em}$ (b) refere-se ao eluato (material não ligado na coluna).

Embora inúmeros testes de purificação na presença de diferentes inibidores de protease, tais como, pepstatina, aprotinina, leupeptina, PMSF e EDTA tenham sido realizados, os efeitos da degradação não foram minimizados. Isso nos leva a acreditar que a degradação da XfDHODH provavelmente se deva a seu caráter hidrofóbico, entretanto a adição de detergentes (Triton X-100, Tween 20, Chapes e dodecil maltosideo) também não foi eficaz neste sentido, o que impossibilitou a realização de ensaios espectroscópicos com esta enzima. $\mathrm{Na}$ verdade, estudos mais recentes realizados para outras construções de XfDHODH indicam que a extensão N-terminal da proteína é susceptível a forte degradação (resultados não apresentados). Ainda mais recente, estão sendo realizados ensaios de expressão com a proteína fusionada a GST (glutationa -S-transferase). Estes estudos indicam que a presença da proteína auxilia na estabilidade e minimiza efeitos de degradação. Estes resultados sugerem que a análise espectroscópica de XfDHODH poderá ser realizada em um futuro próximo. 


\section{Diidroorotato Desidrogenase de Trypanosoma cruzi}




\section{Diidroorotato Desidrogenase de Trypanosoma cruzi}

Em 1909, enquanto realizava uma campanha contra a malária que atingia operários que trabalhavam na construção de um trecho da Estrada de Ferro Central do Brasil, na região norte do Estado de Minas Gerais, o médico brasileiro Carlos Chagas, observou a infestação dos domicílios humanos por um inseto hematófago até então desconhecido - o "barbeiro". Examinando o aparelho digestivo deste inseto que se alimenta de sangue de animais domésticos e humano, verificou a infestação destes por Tripanosomídeos. Mais tarde, examinando o sangue de uma criança febril com sinais agudos de infecção, deparouse com os mesmos organismos flagelados, denominados por ele de Trypanosoma cruzi [107]. Assim, foi diagnosticada pela primeira vez a doença de Chagas, conhecida também como tripanosomíase americana.

Sabe-se que a doença de Chagas pode ser transmitida para os humanos por pelo menos três maneiras: pelo inseto (barbeiro - Figura 58) que deposita suas fezes contendo o parasita no momento da picada, diretamente por transfusão de sangue contaminado ou órgãos transplantados, ou durante a gestação (transmissão congênita). Recentemente, notificou-se que outra forma de transmissão pode ser a ingestão de alimentos contaminados com fezes do inseto contendo o parasita [108].

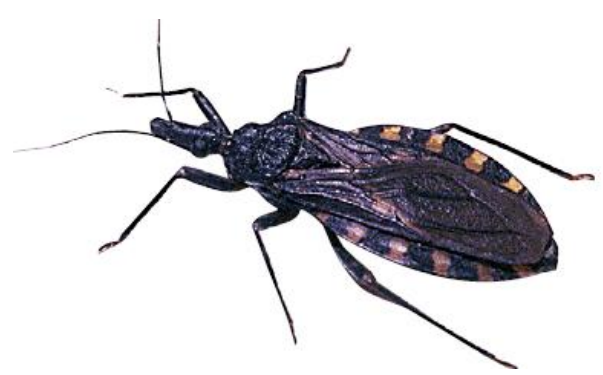

Figura 58 - Inseto Triatoma infestans conhecido popularmente como "Barbeiro", um dos potenciais vetores da doença de Chagas. (fonte: WHO [109]).

A distribuição geográfica da doença se estende desde o norte do México ao sul da Argentina, afetando 10 a 14 milhões de pessoas em todo o mundo [109,110] e, segundo a 
Organização Mundial de Saúde, aproximadamente 25\% da população da América Latina corre o risco de contrair a doença. Com a imigração crescente nos últimos anos, a doença acabou se estendendo da América Latina para outros países como Estados Unidos, Canadá e o continente africano, graças a transfusões de sangue contaminado e órgãos transplantados. O número de contaminações nos bancos de sangue em algumas cidades do cone Sul varia de $1,7 \%$ a $53 \%$, mostrando que o contágio pelo $T$. cruzi através de sangue contaminado é maior que a infecção pelos vírus da Aids e Hepatite C [109]. Além disso, a mortalidade causada pela doença de Chagas na América Latina é uma ordem de grandeza maior que a causada pela malária, esquistossomose e Leishimaniose [111].

Os estágios da doença de Chagas são dois: 1) a fase aguda, a qual se manifesta de 5 a 14 dias após a transmissão pelo barbeiro e 30 a 40 dias para infecções por transfusão sangüínea (nesta fase a mortalidade é inferior a 10\%); 2) a fase crônica, que aparece depois de um longo período sem que a doença se manifeste, período este que pode levar até vários anos [112]. A fase crônica é assintomática e as lesões adquiridas neste estágio da doença são irreversíveis afetando órgãos internos como coração, esôfago e cólon, além do sistema nervoso periférico. Depois de vários anos de período assintomático, 27\% dos infectados desenvolvem sintomas cardíacos que podem levar à morte súbita, $6 \%$ desenvolvem danos no aparelho digestivo e 3\% apresentam lesões no sistema nervoso [109].

O desenvolvimento de novas drogas para o tratamento da doença de Chagas é urgentemente necessário, visto que até o momento não existe nenhum tratamento efetivo para a doença. As drogas mais comumente usadas (compostos nitroheterocíclicos e derivados de nitroimidazol) são tóxicas para o organismo, além de apresentarem baixa atividade antiparasitária na fase crônica da doença, sendo que aproximadamente $80 \%$ dos pacientes tratados não são parasitologicamente curados [113]. Entretanto, há um grande esforço por parte da comunidade científica em entender o mecanismo de patogenicidade do T. cruzi e identificar alvos que inibam a proliferação deste parasita [114-117]. 
Apesar do parasita $T$. cruzi possuir as duas vias de biossíntese de nucleotídeos de pirimidina, vias de novo e salvação, o balanço entre esses dois caminhos biosintéticos varia de acordo com o estágio de desenvolvimento do parasita [118,119].

A presença de DHODH em T. cruzi foi reportada em 1999 por Gao e co-autores, que mostraram pela primeira vez a presença de um fragmento de DNA genômico de $T$. cruzi de aproximadamente $25 \mathrm{~kb}$ contendo os genes que codificam as 6 enzimas da biossíntese de novo de nucleotídeos de pirimidina [6].

Análises filogenéticas da seqüência de aminoácidos de várias DHODHs indicam que a Diidroorotato Desidrogenase de T. cruzi (TcDHODH) está localizada no citoplasma do protozoário e utiliza preferencialmente fumarato como aceptor de elétrons, diferentemente da HsDHODH e EcDHODH, membros da classe 2 das $\mathrm{DHODHs}$, que utilizam quinonas como aceptor final de elétrons na reação enzimática. Além disso, aproximadamente $40 \%$ da atividade total de redução de fumarato na célula é devida a TcDHODH.

A TcDHODH pertencente à classe $1 \mathrm{~A}$ das $\mathrm{DHODHs}$ é um homodímero, sendo a massa molecular de cada monômero igual a $34 \mathrm{kDa}$. Ela apresenta $54 \%$ de identidade seqüencial com LIDHODHA, 23\% com a HsDHODH, 26\% com a EcDHODH. A estrutura do complexo entre LIDHODH e o produto da reação, orotato, revela os resíduos envolvidos na função enzimática: Asn67, Asn127, Asn132, Asn193, Lys43, Ser194, Met69, Gly70, Leu71 [16]. Uma análise estrutural entre a LIDHODH e a TcDHODH, revela que todos os resíduos que participam na ligação com o cofator FMN e com o produto da catálise são conservados na estrutura de $T$. cruzi, sugerindo similaridades no modo de atuação de ambas as enzimas. O alinhamento seqüência da Figura 59 mostra alguns desses resíduos conservados. 


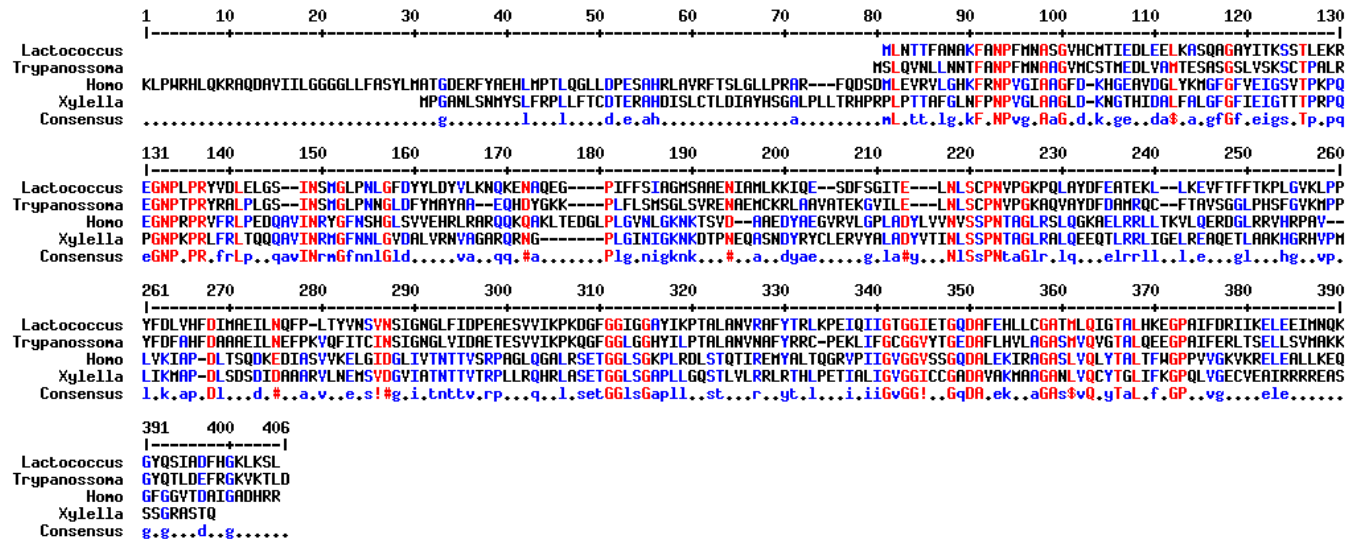

Figura 59 - Alinhamento seqüencial entre DHODH de Lactococcus lactis, Trypanosoma cruzi, Homo sapiens e Xylella fastidiosa. Alinhamento e figura foram feitos utilizando o programa Multalin [66].

Recentemente, o grau de importância desta enzima para a atividade celular foi demonstrado por Annoura et al. [120]. Estes pesquisadores mostraram que o "nocaute" do gene pyr4 (codificador da TcDHODH) levaria o protozoário à morte mesmo na presença de precursores de pirimidina, indicando que a DHODH é essencial para o parasita, desempenhando um papel extremamente importante não só na biossíntese de novo, mas também na homeostase redox do protozoário. Dessa forma, a TcDHODH poderia ser um excelente alvo para o desenvolvimento de drogas contra a doença de Chagas.

Embora, o objetivo deste trabalho não seja o desenho de fármacos contra a doença de Chagas, acreditamos que a caracterização estrutural da enzima possa auxiliar na busca por drogas efetivamente mais eficientes no tratamento da doença. Nossos resultados, corroborados com os resultados obtidos através da determinação recente da estrutura cristalográfica da DHODH de $T$. cruzi $[24,121,122]$ são ferramentas essenciais para a compreensão do mecanismo de ação da TcDHODH. 


\subsection{Metodologia}

\subsubsection{Expressão e Purificação da TcDHODH}

O gene codificador da enzima TcDHODH (gene pyr4) foi clonado no vetor de expressão pET28a pela Profa. Dra. Maria Cristina Nonato (FCFRP-USP). A produção da enzima TcDHODH exógena foi conduzida em células de E. coli BL21(DE3) através da indução com $1 \mathrm{mM}$ de IPTG a $25{ }^{\circ} \mathrm{C}$ por 5 horas. A purificação da enzima foi realizada através de cromatografia por afinidade em condições nativas a $4{ }^{\circ} \mathrm{C}$. Para isso, células provenientes de $250 \mathrm{~mL}$ de meio de cultura foram resuspensas em $10 \mathrm{~mL}$ do tampão de resuspensão $\left(\mathrm{NaH}_{2} \mathrm{PO}_{4} 50 \mathrm{mM}, \mathrm{NaCl} 300 \mathrm{mM}, \mathrm{pH}\right.$ 8,0). Em seguida, as células foram rompidas mecanicamente por 12 ciclos de 30 segundos de ultrassonicação (potência de 10 W) com intervalos de 60 segundos. A fração insolúvel foi então separada da fração solúvel por centrifugação a $20.000 \times$ g durante 30 minutos à $4{ }^{\circ} \mathrm{C}$. A fração solúvel foi aplicada em coluna de cromatografia Ni-NTA (Quiagen). O preparo da coluna cromatográfica foi realizado com adição de $2 \mathrm{~mL}$ da resina em uma coluna de prolipropileno de $20 \mathrm{~mL}$ que foi empacotada por gravidade. Após a drenagem do etanol $20 \%$, a resina foi lavada com $40 \mathrm{~mL}$ de água milli-Q e equilibrida com $10 \mathrm{~mL}$ de tampão $\mathrm{NaH}_{2} \mathrm{PO}_{4} 50$ mM, NaCl 300 mM, pH 8,0. O extrato protéico foi aplicado à coluna e, em seguida, a resina foi lavada com $34 \mathrm{~mL}$ do tampão de resuspensão para eliminar contaminantes. A seguir, a coluna foi lavada com 64 $\mathrm{mL}$ e $10 \mathrm{~mL}$ do tampão $\mathrm{NaH}_{2} \mathrm{PO}_{4} 50$ mM, NaCl 300 mM, pH 8,0, contendo 25 mM e $50 \mathrm{mM}$ de imidazol, respectivamente. A proteína recombinante foi eluída em 16 frações de $2 \mathrm{~mL}$ na presença de $100 \mathrm{mM}$ de imidazol no tampão $\mathrm{NaH}_{2} \mathrm{PO}_{4} 50 \mathrm{mM}, \mathrm{NaCl} 300$ mM, pH 8,0. Em todas as etapas foram armazenadas alíquotas das soluções para análise por eletroforese em gel de poliacrilamida (SDS-PAGE) $15 \%$. 


\subsubsection{Dicroísmo circular}

Medidas do conteúdo de estrutura secundária da TcDHODH foram feitas utilizandose o espectrômetro Jasco J-720 equipado com banho de água (TC100) e controlador de temperatura (Jasco PFD 425S). O experimento foi feito com a amostra em tampão fosfato de sódio $50 \mathrm{mM}(\mathrm{pH}$ 8,1) e utilizando-se cubeta de quartzo retangular de caminho óptico de $1 \mathrm{~mm}$. As medidas foram realizadas na região do ultravioleta distante (190-250 nm) com sensibilidade igual a $100 \mathrm{mGraus,}$ velocidade de varredura de $100 \mathrm{~nm} \cdot \mathrm{min}^{-1}$, largura da banda de $1 \mathrm{~nm}$ e tempo de resposta de $0,5 \mathrm{~s}$. O espectro final é o resultado da média de 16 varreduras. Quando necessário, os espectros de CD em um dado comprimento de onda foram convertidos para elipticidade molar média por resíduo $[\theta] \lambda$ (em graus $\mathrm{cm}^{2} \mathrm{dmol}^{-1}$ ) usando a relação $[\theta]_{\lambda}=\left(\theta_{\lambda} M_{0}\right) /(10 \ell \quad c)$, onde $\theta_{\lambda}$ é a elipticidade observada em miligraus, $M_{0}$ é a massa média por resíduo $\left(M_{0}=115\right)$, $c$ é a concentração de proteína $(\mathrm{mg} / \mathrm{mL})$, e $\ell$ é o caminho óptico (cm).

\subsubsection{Desnaturação térmica}

A desnaturação térmica foi monitorada no comprimento de onda de $222 \mathrm{~nm}$. A temperatura foi variada de 5 a $90{ }^{\circ} \mathrm{C} \operatorname{com} \Delta \mathrm{T}=5^{\circ} \mathrm{C}$ (usando uma razão de aquecimento de $\left.1{ }^{\circ} \mathrm{C} / \mathrm{min}\right)$. A DHODH de $T$. cruzi foi empregada em uma concentração de aproximadamente $0,44 \mathrm{mg} / \mathrm{mL}(12,8 \mu \mathrm{M})$. Após o processo de desnaturação por aquecimento, a amostra foi imediatamente resfriada para verificarmos a reversibilidade da reação. Nos experimentos em que orotato foi adicionado a amostra protéica, a concentração de orotato empregada foi de $128 \mu \mathrm{M}$. 


\subsection{Resultados e Discussões}

\subsubsection{Purificação da TcDHODH}

A enzima TcDHODH foi clonada e expressa na forma solúvel com sucesso. O processo de purificação por cromatografia de afinidade também se mostrou bastante satisfatório no que diz respeito ao grau de pureza da enzima, como pode ser observado na Figura 60. A enzima foi expressa em grande quantidade e o nível de pureza obtido foi bastante elevado.

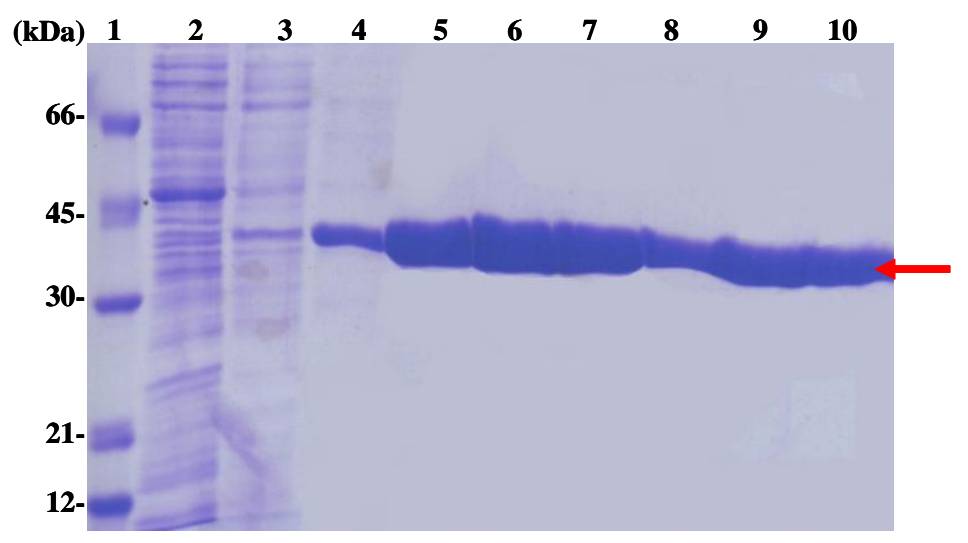

Figura 60 - Resultado da análise por eletroforese em gel SDS-PAGE da purificação da TCDHODH em coluna Ni-NTA. SDS-PAGE 15\%. Coluna1, padrão de massa molecular em kDa ; Coluna 2, eluato das proteínas totais aplicadas à coluna (material não ligado); Coluna 3, lavagem com $25 \mathrm{mM}$ de imidazol; Coluna 4 lavagem com $50 \mathrm{mM}$ de imidazol; Colunas 5 a 10, proteína (TcDHODH) eluída com $100 \mathrm{mM}$ de imidazol.

Análises do estado de oligomerização da TcDHODH após a purificação na coluna NiNTA foram feitas pela Dra. Maria Cristina Nonato e indicaram que a TcDHODH apresenta-se na forma homodimérica. Para tanto, foi utilizado cromatografia por exclusão molecular em coluna Sefacril S-100 (GE - Life Sciences). 


\subsubsection{Análise da estabilidade térmica da TcDHODH}

O espectro de CD da enzima TcDHODH em tampão $\mathrm{Na}_{2} \mathrm{PO}_{4} 50 \mathrm{mM}(\mathrm{pH} 8,0)$ a $20{ }^{\circ} \mathrm{C}$ está mostrado na Figura 61 e é caracterizado por duas bandas negativas em cerca de 210 e 222 nm e uma banda positiva em torno de 197 nm. O mínimo em 222 nm é atribuído majoritariamente a transições encontradas em estruturas helicoidais [123], ao passo que a banda negativa em torno de $210 \mathrm{~nm}$ é provavelmente resultado de uma mistura do mínimo em $208 \mathrm{~nm}$ decorrente de estruturas em hélice com a banda em $215 \mathrm{~nm}$ oriunda de transições observadas em fitas $\beta$, o que sugere, portanto, uma estrutura da proteína envolvendo combinações do tipo $\alpha / \beta$. Além disso, a intensidade comparável do máximo em 197 nm e do mínimo em torno de 220 nm aponta para existência de quantidades apreciáveis de folhas $\beta$ e "turns". Estes fatos estão de acordo com a estrutura clássica encontrada tanto para DHODHs de classe 1 quanto de classe 2.

Para investigarmos a influência de ligantes na estrutura da TcDHODH, também realizamos medidas de CD na presença do produto da reação enzimática (orotato). Esta molécula atua como um inibidor natural de DHODH quando em altas concentrações. Assim, na Figura 61, também é mostrado o espectro de CD da TcDHODH na presença de orotato em uma concentração dez vezes maior que a de proteína. Características espectrais similares são observadas quando comparamos este resultado com aquele obtido na ausência do ligante, assim indicando que o conteúdo global de estrutura secundária da proteína não foi significativamente alterado pela ligação do orotato. Entretanto, algumas mudanças podem ser detectadas, tais como um leve desvio para o azul (blue-shift) do comprimento de onda no qual ocorre o cruzamento do espectro com o eixo referente a intensidade nula de CD e uma banda mais intensa em 197 nm para TcDHODH na ausência de orotato. Tais mudanças podem ser atribuídas a uma diminuição no conteúdo de $\alpha$-hélice ou a um rearranjo desfavorável de hélices quando da ligação da molécula de orotato $[124,125]$ 


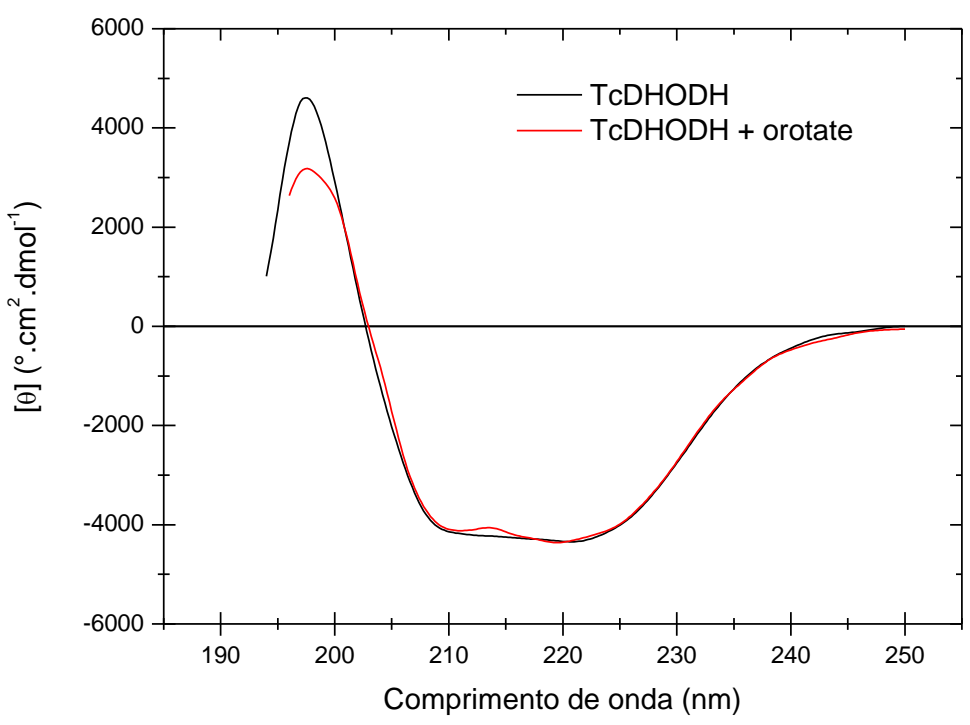

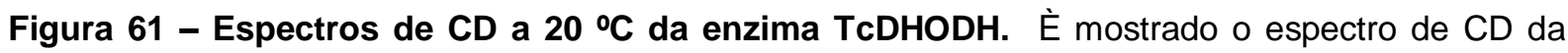
enzima pura (linha preta) e o espectro de CD de TcDHODH quando da adição de orotato $128 \mu \mathrm{M}$ (linha vermelha).

A influência do orotato na estrutura da TcDHODH foi, ainda, investigada através do estudo do processo de desnaturação térmica da enzima na ausência e na presença do ligante. Experimentos de CD em função da temperatura (Figura 62) realizados com a TcDHODH em ambas as situações resultaram em espectros na região do UV distante caracterizados por um decréscimo global da elipticidade e pela presença de um ponto isodicróico em torno de $204 \mathrm{~nm}$ (ponto de intersecção de todos os espectros), o que sugere uma transição envolvendo apenas dois estados (nativo e desnaturado). Além disso, a desnaturação, na ausência e na presença do orotato, é um processo irreversível já que amostras resfriadas para $20^{\circ} \mathrm{C}$ imediatamente após o processo de aquecimento originaram espectros de CD bastante diferentes daqueles inicialmente obtidos para a mesma temperatura. Assim, TcDHODH não retornou para seu estado nativo inicial mesmo após resfriamento. 
A

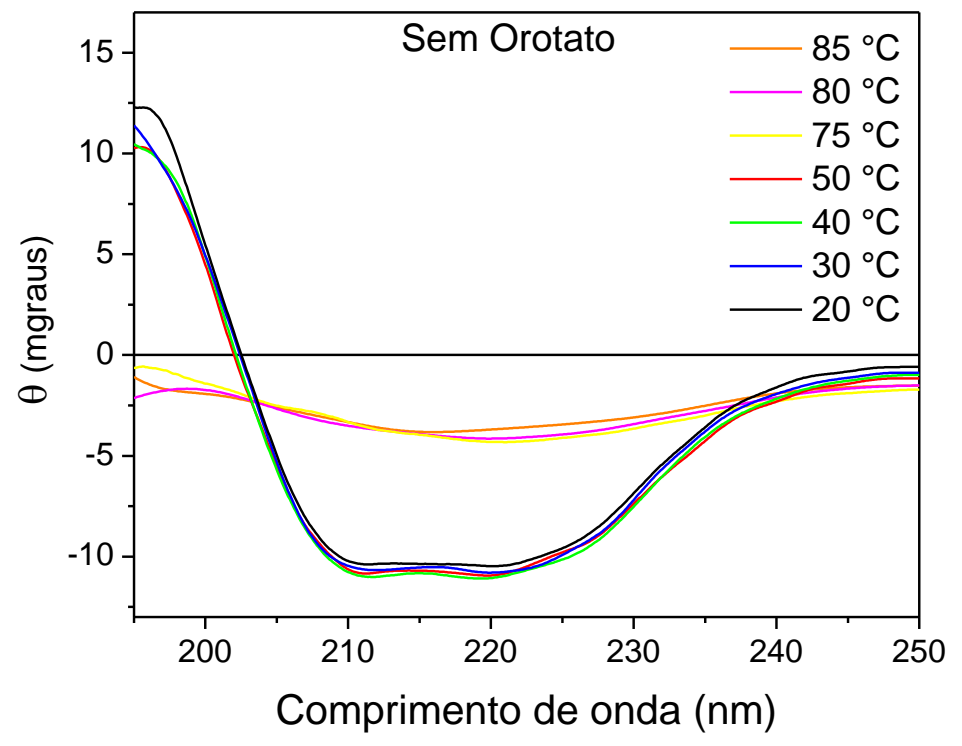

B

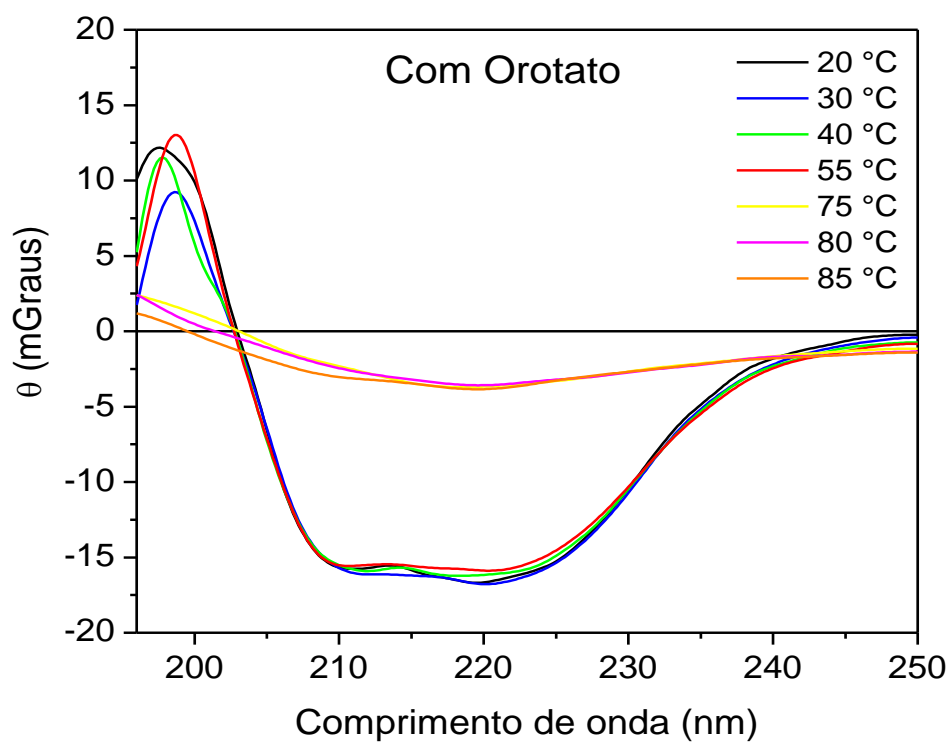

Figura 62 - Desnaturação térmica da TcDHODH avaliada por dicroísmo circular. (A) Enzima pura e (B) enzima na presença de orotato. A desnaturação induzida termicamente revela a presença do ponto isodicróico em torno de $204 \mathrm{~nm}$.

A variação da elipticidade medida em 222 nm, um comprimento de onda considerado como um índice de estrutura secundária de proteínas, como função da temperatura (Figura 63) exibiu um comportamento do tipo sigmoidal, típico de processos cooperativos, que se inicia em torno de $40{ }^{\circ} \mathrm{C}$ e que está quase completamente finalizado em torno de $60{ }^{\circ} \mathrm{C}$. A presença do orotato não afetou as características gerais da curva de desnaturação obtida para a TcDHODH. 
Para uma análise mais quantitativa e levando em conta os resultados acima, o processo de desnaturação térmica da TcDHODH, na ausência e na presença de orotato, foi tratado como um processo irreversível de dois estados descrito por:

$$
\mathrm{N} \stackrel{k}{\longrightarrow} \mathrm{D}
$$

onde $\mathrm{N}$ e $\mathrm{D}$ são as formas nativa e desnaturada da enzima e $k$ é a constante de velocidade da reação, cuja dependência com a temperatura segue a equação de Arrhenius,

$$
k=A \exp \left(-E_{a} / R T\right)
$$

onde $E_{a}$ é a energia de ativação do processo.

As frações de proteína desnaturada, $f_{\mathrm{D}}$, e nativa, $f_{\mathrm{N}}$, são dadas por:

$$
f_{\mathrm{D}}=\left(\theta_{\mathrm{N}}-\theta_{\mathrm{T}}\right) /\left(\theta_{\mathrm{N}}-\theta_{\mathrm{D}}\right) \quad \text { e } \quad f_{\mathrm{D}}+f_{\mathrm{N}}=1
$$

onde $\theta_{\mathrm{T}}$ é a elipticidade da amostra em uma certa temperatura, $\theta_{\mathrm{D}}$ e $\theta_{\mathrm{N}}$ são os valores característicos da elipticidade dos estados desnaturado e nativo, respectivamente. A fração de protegem nativa, $f_{N}$, por sua vez, depende da temperatura de acordo com a relação [126]

$$
\ln \left[\ln \left(1 / f_{\mathrm{N}}\right)\right]=\left(E_{\mathrm{a}} / R\right)\left(1 / T_{\mathrm{m}}-1 / T\right),
$$

onde $T_{\mathrm{m}}$ é a temperatura de transição.

Os valores de elipticidade foram transformados em frações de proteína nativa $\left(f_{N}\right)$ e desnaturada $\left(f_{D}=1-f_{N}\right)$ e a variação dessa fração é apresentada na Figura 63. Esses valores foram, então, utilizados para construirmos gráficos de $\ln \left[\ln \left(1 / f_{N}\right)\right]$ em função de $1 / T$, que foram, por sua vez, ajustados a funções lineares como descrito pela equação 5 . A partir do coeficiente angular desses gráficos, uma energia de ativação media foi calculada para a enzima TcDHODH $(131 \mathrm{~kJ} / \mathrm{mol})$ e para TcDHODH na presença de orotato $(150 \mathrm{~kJ} / \mathrm{mol})$. Além disso, dos valores de coeficiente linear obtidos, determinamos a temperatura de transição $\left(T_{\mathrm{m}}\right)$ para cada caso e que apresentou uma mudança para mais altas temperaturas pela adição de orotato $\left(T_{\mathrm{m}}=330,4 \pm 0,2 \mathrm{~K}\right.$ para $\mathrm{TcDHODH}$ e $T_{\mathrm{m}}=333,1 \pm 0,1 \mathrm{~K}$ para $\mathrm{TcDHODH}$ com excesso de orotato). Ambos os parâmetros, energia de ativação e $T_{\mathrm{m}}$, indicam que a ocupação do sítio de ligação na estrutura da TcDHODH pela molécula de orotato confere à proteína uma maior estabilidade estrutural. 
Em células que se proliferam rapidamente, ácidos nucléicos são continuamente sintetizados através de uma estratégia geral que envolve a produção seqüencial precursores $\rightarrow$ nucleotídeos $\rightarrow$ ácido nucléico. Vias biosintéticas que envolvem reações seqüenciais, onde o produto de uma reação serve de substrato para o próximo passo, são normalmente reguladas através de mecanismos de inibição do tipo feedback, onde o produto de uma das reações acaba servindo como inibidor de alguma das enzimas da via. Processos de regulação como este tem de ser finamente ajustados para que se, por algum motivo, a síntese de ácidos nucléicos diminuir, nucleotídeos não se acumulem indefinidamente. A enzima DHODH faz parte de uma cascata de reações que culmina com a produção de UMP. A molécula de orotato, produto da reação catalisada pela $\mathrm{DHODH}$, é sabidamente um inibidor natural da enzima. Nossos resultados de CD mostram que o orotato ao se ligar à enzima $\mathrm{DHODH}$, inibindo-a, forma um complexo com estabilidade estrutural ligeiramente maior do que aquela observada para a enzima na ausência do inibidor. Os valores calculados para a energia de ativação e temperatura de transição apontam para uma maior estabilidade do complexo, mas sem levar a uma situação de estabilidade desproporcionalmente maior e que inviabilizaria o desligamento do inibidor natural quando a enzima fosse necessária em sua forma ativa pela célula. Esse mecanismo de regulação da atividade biológica usado pela TcDHODH parece ser compartilhado pelas enzimas da classe 1 de DHODH. 


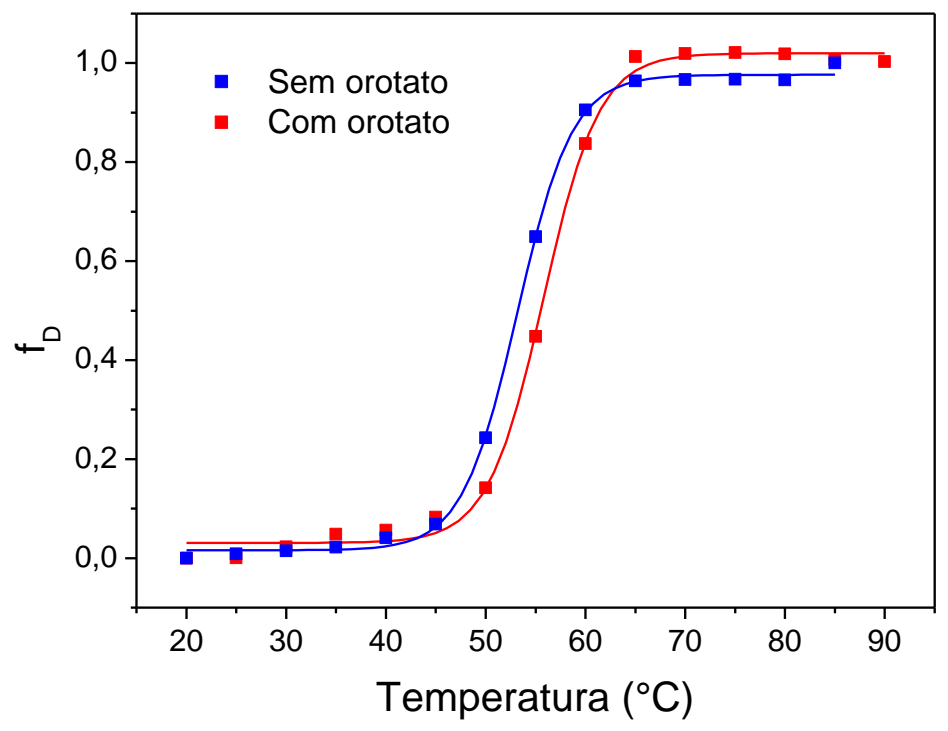

Figura 63 - Curva de transição das mudanças estruturais sofridas pela TcDHODH na presença e ausência de orotato. Desnaturação térmica da TcDHODH, monitorada em $222 \mathrm{~nm}$, expressa em termos da fração de proteína desnaturada, $f_{D}$, em função da temperatura. Na presença de orotato (linha e pontos vermelhos) e na ausência de orotato (linha e pontos azuis). 
Conclusões 


\section{Conclusões}

Os estudos desenvolvidos no presente trabalho de tese envolveram uma abordagem biofísica/bioquímica em busca de informações estruturais e funcionais da enzima diidroorotato desidrogenase de vários organismos. Esta enzima participa de uma das vias de biossíntese de nucleotídeos de pirimidina e o interesse pelo entendimento dos mecanismos, em nível molecular, que regulam seu funcionamento reside exatamente na importância do produto final da cadeia de reações em que a enzima é participante.

Assim, obedecendo a uma ordem cronológica de execução do projeto, iniciamos o trabalho com a DHODH de Xylella fastidiosa, pois esta possuía um apelo óbvio, o seu envolvimento na chamada doença do amarelinho, em relação à relevância da investigação de seu mecanismo de funcionamento. A XfDHODH faz parte da classe 2 de $\mathrm{DHODH}$, cujos membros apresentam uma extensão em seu $\mathrm{N}$-terminal e que a torna uma enzima associada a membranas biológicas. No entanto, esta característica também a torna uma proteína de difícil obtenção. Várias construções foram utilizadas na tentativa de se obter proteína solúvel e em quantidade adequada para os estudos espectroscópicos, mas nenhuma gerou resultados que nos permitissem avançar com a investigação molecular pretendida. Mesmo assim, acabamos por incluir em nosso trabalho final um capítulo com um apanhado das várias estratégias realizadas com o intuito de que construíssemos um documento que pudesse ser utilizado como ponto de partida para trabalhos futuro dentro de nosso grupo de pesquisa.

Com o insucesso na obtenção da enzima XfDHODH e com a gentil ajuda do Prof. Kaj Jensen (Universidade de Copenhague), obtivemos a construção pAG1 codificadora da DHODH de Escherichia coli (EcDHODH) para os experimentos iniciais de expressão e purificação, além das cepas de E. coli SO6645 e SO6740. A partir deste material e com ajustes sempre que preciso, conseguimos produzir enzima em condições adequadas para os experimentos inicialmente planejados para a XfDHODH, já que EcDHODH também é 
membro da classe 2 de DHODH e também interage com membranas durante sua atividade catalítica.

Com o protocolo de expressão e purificação da enzima de Escherichia coli na forma solúvel bem estabelecido e fornecendo bom rendimento com alta atividade enzimática, nos permitiu a realização dos experimentos de RPE. Estes foram sempre realizados na presença do detergente Triton X-100 tanto nas amostras controle (vesícula sem EcDHODH) quanto na vesícula contendo a enzima e mostraram interação significativa desta última com os modelos de membrana utilizados. A independência da interação EcDHODH/vesícula em relação à carga superficial da vesícula também foi observada visto que alterações similares foram obtidas para vesículas contendo tanto o fosfolipídio zwiteriônico DOPC quanto o negativamente carregado DOPG. As alterações nos espectros de RPE para os marcadores 5-PC e 10-PC foram mais intensas que aquelas observadas para os marcadores DPPTC, 12-PC e 16-PC e consistiram basicamente do aparecimento de uma segunda componente espectral que apresentava espectro de linhas bastante estreitas. Esta nova componente provavelmente está associada a marcadores de spin localizados nas vizinhanças da $\mathrm{EcDHODH}$.

Para melhor quantificar e caracterizar o mecanismo de ligação (ou "docking") da proteína nos modelos de membrana realizamos simulações dos espectros de RPE através do programa NLSL. Este programa fornece, ao final dos ajustes, parâmetros que caracterizam a mobilidade e a polaridade no micro-ambiente em torno do marcador de spin. Nossos resultados mostraram que a enzima EcDHODH deve promover a formação de um defeito na região hidrofóbica das cadeias carbônicas dos fosfolipídios, associado com a segunda componente existente nos espectros dos marcadores 5-PC e 10-PC. Essa segunda componente apresenta valores de $A_{0}$ (medida indireta da polaridade) e $R_{\perp}$ (medida da mobilidade) mais elevados que aqueles obtidos para o mesmo marcador localizado no "bulk" da micela. Além disso, o valor de $A_{0}(16,0 \mathrm{G})$ dessa componente 2 aponta para um ambiente polar experimentado pelo marcador, possivelmente devido à anfipaticidade das hélices que formam o domínio $\mathrm{N}$-terminal e que é o suposto responsável pela interação 
entre a enzima e a membrana. A inserção dessa região $\mathrm{N}$-terminal é apenas parcial como visto dos espectros de RPE, o que está também de acordo com o padrão de hidrofobicidade/hidrofilicidade observado para os resíduos que compõem esse domínio.

Com o intuito de investigarmos o efeito da presença da enzima EcDHODH também do ponto de vista da proteína, em particular da sua extensão $\mathrm{N}$-terminal, passamos a realizar estudos pela técnica de marcação de spin sítio dirigida (SDSL). Aqui cabe ressaltar um objetivo mais geral do presente trabalho que foi a implantação desta metodologia de SDSL em nosso laboratório e que, até onde pudemos nos informar, trata-se também de uma metodologia inédita em nosso país. No entanto, a técnica de SDSL requer um esforço grande em termos de produção de amostra, talvez maior do que o normalmente encontrado em projetos envolvendo o uso de técnicas espectroscópicas em proteínas comerciais ou com protocolos de preparação bem estabelecidos. Cada mutante a ser utilizado pode necessitar de um protocolo específico de obtenção. Isto quer dizer que estivemos lidando, ao longo do desenvolvimento de toda essa parte do projeto, com problemas de biologia molecular/bioquímica. Acreditamos que os resultados alcançados e ainda por alcançar com o completo estabelecimento da técnica de SDSL constituem o maior agente motivador para se realizar essa quantidade grande de preparações de amostras.

Em termos mais específicos, conseguimos produzir e marcar com sucesso quatro resíduos pertencentes à região $\mathrm{N}$-terminal de $\mathrm{EcDHODH}$ : Y2, F5, H19 e F21. Os espectros da cadeia lateral R1 ligada a cada um desses resíduos nos dão informações valiosas acerca da dinâmica experimentada pelo marcador de spin em cada situação. Para os mutantes Y2R1 e F5R1 obtivemos espectros com única componente associada com uma mobilidade alta, o que é coerente com a posição de tais resíduos bem no começo da seqüência de aminoácidos que compõem a proteína.

Os espectros dos mutantes H19R1 e F21R1 apresentam duas componentes, sendo uma com característica de uma situação de dinâmica rápida e outra com movimento imobilizado. O resíduo nativo $\mathrm{H} 19$ está posicionado em uma região em que muitos contatos com átomos de resíduos vizinhos espacialmente podem participar de um processo de 
restrição de movimento, o que explica a componente mais imobilizada do espectro de SDSL-RPE. Por outro lado, a origem da componente de dinâmica rápida em tal situação não pode ser entendida dentro desta análise, o que nos levou a propor que flutuações locais da cadeia principal permitam que a cadeia lateral R1 experimente uma conformação em que estaria mais livre dos contatos interatômicos com vizinhos, assim possibilitando a existência de um espectro de SDSL-RPE atribuível a uma mobilidade maior do que aquela observada para a outra componente espectral. Por fim, o espectro do mutante F21R1, também com duas componentes, tem sua origem racionalizada em termos da existência de rotâmeros experimentados pela cadeia lateral R1 mesmo em uma situação de poucos ou nenhum contatos terciários observada a partir da estrutura cristalográfica de EcDHODH.

Os resultados conjuntos para estes quatro mutantes sugere que a região do $\mathrm{N}$ terminal de EcDHODH possa experimentar uma mobilidade/flexibilidade considerável, diferentemente do que poderia se supor a partir da estrutura tridimensional da EcDHODH. Esta maior flexibilidade é, ainda, coerente com nossos resultados de RPE utilizando derivados de fosfolipídios como marcadores de spin, e com o que se esperaria de uma região que deve experimentar uma situação dinâmica que permita a ligação das moléculas de aceptores de elétrons que participam do processo de catálise enzimática. Em relação ao nosso objetivo mais geral, acreditamos que podemos considerar que a técnica de SDSL está estabelecida em nosso grupo e que pode ser estendida não apenas a mais mutantes da EcDHODH (trabalho futuro), de forma a termos um estudo sistemático da região $\mathrm{N}$ terminal, mas também a outras proteínas de interesse do grupo.

Finalmente, em paralelo aos estudos com $\mathrm{DHODH}$ de classe 2, conduzimos experimentos com a enzima de Trypanosoma cruzi, membro da classe 1 de DHODH. Nesta etapa, o objetivo era a realização de um estudo mais pontual acerca do efeito da presença do produto da reação, que sabidamente atua como inibidor natural da enzima, sobre a estrutura da proteína. Para isso, procedemos com experimentos de dicroísmo circular na região do UV distante e monitoramos mudanças no conteúdo de estrutura secundária da TcDHODH quando submetida a um processo de desnaturação térmica na ausência e na 
presença de um excesso de orotato. Nossos resultados mostraram que a ligação do orotato confere uma estabilidade térmica ligeiramente maior para a enzima e sugere que a tal ligação possa ser um mecanismo de regulação da atividade enzimática. 


\section{Referencias*}

[1] NELSON, D. L.; COX, M. M. Biosynthesis of Amino Acids, Nucleotides, and Relatade molecles. In:_. Lehninger - Principles of Biochemistry. 4. ed. New York: W. H. Freeman, 2004. p. $862-880$

[2] HUANG, M.; GRAVES, L. M. De novo synthesis of pyrimidine nucleotides: emerging interfaces with signal transduction pathways. Cellular and Molecular Life Science, v. 60 , p. $321-336,2003$.

[3] LÖFFLER, M. et al. Pyrimidine pathways in health and disease. Trends in Molecular Medicine, v. 11, p. 430-437, 2005.

[4] FAIRBANKS, L. D. et al. Importance of ribonucleotide availability to proliferating Tlynphocytes from healthy humans. Journal of Biological Chemistry, v. 270, p. 29682-29689, 1995.

[5] STRYER, L. Biosynthesis of nucleotides in: WH Freeman and Company, 1995. p. 739-758.

Biochemistry. 4. ed. New York:

[6] GAO, G. et al. Novel organization and sequences of five genes encoding all six enzymes for de novo pyrimidine biosynthesis in Trypanosoma cruzi. Jounal of Molecular Biology, v. 285, p. 149-161, 1999.

[7] JONES, M. E. Pyrimidine nucleotide biosynthesis in animals: genes, enzymes, and regulation of UMP biosynthesis. Annual Review of Biochemistry, v. 49, p. 253-279, 1980.

[8] JONES, M. E. Regulation of pyrimidine and arginine biosynthesis in mammals. Advances in Enzyme Regulation, v. 9, p. 19-49, 1970.

[9] NARA, T. et al. Localization of carbamoyl- phosphate synthetase II (CPS II) and aspartate carbamoyltransferase (ACT) genes in Trypanosoma cruzi chromosomal DNA. Advances in Experimental Medicine and Biology, v. 431, p.227-230, 1998.

[10] NARA, T. et al. Carbamoyl-phosphate synthetase II in kinetoplastids. Biochimica et Biophysica Acta-Protein Structure and Molecular Enzymology, v. 1387, p. 462468, 1998.

* De acordo com:

ASSOCIAÇÃO BRASILEIRA DE NORMAS TÉCNICAS NBR6023: informação e documentação: referencias: elaboração. Rio de janeiro, 2002. 
[11] IWAHANA, $\mathrm{H}$. et al. Molecular cloning of a human cDNA encoding a trifunctional enzyme of carbamoyl-phosphate synthetase-aspartate transcarbamoylasedihydroorotase in de novo pyrimidine synthesis. Biochemical and Biophysical Research Communications, v. 219, p. 249-255, 1996.

[12] FELICIANO, P. R. et al. Cloning, expression, purification, and characterization of Leishmania major dihydroorotate dehydrogenase. Protein Expression and purification, v. 48, p. 98-103, 2006.

[13] LIEBERMAN, I.; KORNBERG, A. Enzymic synthesis and breakdown of a pyrimidine, orotic acid. I. Dihydroorotic dehydrogenase. Biochimica et Biophysica Acta, v. 12, p. 223-234. 1953.

[14] DIMITRIJEVIC, M.; BARTLETT, R. R. Leflunomide, a novel immunomodulating drug, inhibits homotypic adhesion of peripheral blood and synovial fluid mononuclear cells in rheumatoid arthritis. Inflammation Research, v. 45, p. 550-556, 1996.

[15] SMOLEN, J. S. et al. Efficacy and safety of leflunomide compared with placebo and sulphasalazine in active rheumatoid arthritis: a double-blind, randomised, multicentre trial. Lancet. v. 353, p. 259-266, 1999.

[16] ROWLAND, P. et al. The crystal structure of Lactococcus lactis dihydroorotate dehydrogenase $A$ complexad with the enzyme reaction product throws light on its enzymatic function. Protein Science, v. 7, p. 1269-1279, 1998.

[17] KNECHT, W.; HENSELING, J.; LOFFLER, M. Kinetics of inhibition of human and rat dihydroorotate dehydrogenase by atovaquone, lawsone derivatives, brequinar sodium and polyporic acid. Chemico-Biological Interactions, v. 124, p. 61-76, 2000.

[18] BALDWIN, J. et al. Malarial dihydroorotate dehydrogenase: substrate and inhibitor specificity. Journal of Biological Chemistry, v. 277, p. 41827-41834, 2002.

[19] BJÖRNBERG O. et al. Active site of dihydroorotate dehydrogenase A from Lactococcus lactis investigated by chemical modification and mutagenesis. Biochemistry, v. 36, p. 16197-16205, 1997.

[20] SORENSEN, P.G.; DANDANELL, G. A new type of dihydroorotate dehydrogenase, type 1S, from the thermoacidophilic archaeon Sulfolobus solfataricus. Extremophiles, v. 6, p. 245-251, 2002.

[21] LIU, S. et al. Structures of human dihydroorotate dehydrogenase in complex whit antiploriferative agents. Structure with Folding \& Design, v. 8, p. 25-33, 2000. 
[22] NORAGER, S. et al. E. coli dihydroorotate dehydrogenase reveals structural and functional distinctions between different classes of dihydroorotate dehydrogenase, Structure, v. 10, p. 1211-1223, 2002.

[23] ROWLAND, P. et al. The crystal structureof the flavin containing enzyme dihydroorotate dehydrogenase A from Lactococcus lactis. Structure, v. 5, p. 239252, 1997.

[24] INAOKA, D. K. et al. Crystal structure of native Trypanosoma cruzi dihydroorotate dehydrogenase. Disponível em: <http://www.rcsb.org/pdb/home/home.dol>. Acesso em 12 de Dezembro de 2007.

[25] HANSEN, M. et al. Inhibitor binding in a class 2 dihydroorotate dehydrogenase causes variations in the membrane-associated $\mathrm{N}$-terminal domain. Protein Science, v. 13, p. 1031-1042, 2004.

[26] HURT, D. E.; WIDOM, J.; CLARDY, J. Structure of Plasmodium falciparum dihydroorotate dehydrogenase with a bound inhibitor. Acta Crystallographica, v. D62, p. 312-323, 2006.

[27] ANDERSEN, P. S.; JANSEN, P. J. G.; HAMMER, K. Two different dihydroorotate dehydrogenases in Lactococcus lactis. Journal of Bacteriology, v. 176, p. 39753982, 1994.

[28] NORAGER, S. et al. Lactococcus lactis dihydroorotate dehydrogenase A mutants reveal important facets of the enzymatic function. Journal of Biological Chemistry, v. 278, p. 28812-28822, 2003.

[29] ANDERSEN, P. S.; MARTINUSSEN, J.; HAMMER, K. Sequence analysis and identification of the pyrKDbF operon from Lactococcus lactis including a novel gene, pyrK, involved in pyrimidine biosynthesis. Journal of Bacteriology, v. 178, p. 50055012, 1996.

[30] NIELSEN, F. S. et al. Purification and characterization of dihydroorotate dehydrogenase $A$ from Lactococcus lactis, crystallization and preliminary X-ray diffraction studies of the enzyme. Protein Science, v. 5, p. 85-856, 1996.

[31] NIELSEN, F. S.; ANDERSEN, P. S.; JENSEN, K. F. The B form of dihydroorotate dehydrogenase from Lactococcus lactis consists of two different subunits, encoded by the pyrDb and pyrK genes, and contains FMN, FAD, and [FeS] redox centres. Journal of Biological Chemistry, v. 271, p. 29359-29365, 1996. 
[32] KNECHT, W.; LÖFFLER, M. Species-related inhibition of human dihydroorotate dehydrogenase by immunosuppressive isoxazol and cinchoninic acid derivatives. Biochemical Pharmacology, v. 56, p. 1259-1264, 1998.

[33] COPELAND, R. A. et al. Helicobacter pylori-selective antibacterials based on inhibition of pyrimidine biosynthesis. Journal of Biological Chemistry, v. 275, p. 33373-33378, 2000.

[34] BJÖEMBERG, O. et al. The Activity of Escherichia coli dihydroorotate dehydrogenase is dependent on a conserved loop identified by sequence homology, mutagenesis, and limited proteolysis. Biochemistry, v. 38, p. 2899-2908, 1999.

[35] HUBBELL, W. L.; McCONNELL H. M. Molecular motion in spin-labeled phospholipids and membranes. Journal of the American Chemical Society, v. 93, p. 314-326, 1971.

[36] BERLINER, L. J. Spin Labeling Theory and Applications II. New York: Academic Press, 1979. $357 \mathrm{p}$.

[37] HUBBELL, W. L. et al. Watching proteins move using site-directed spin labeling. Structure, v. 4, p. 779-783, 1996.

[38] BORBAT, P. P. et al. Electron spin resonance in studies of membranes and proteins. Science, v. 291, p. 266-269, 2001.

[39] DONG, J. H.; YANG, G. Y.; MCHAOURAB, H. S. Structural basis of energy transduction in the transport cycle of Msb. Science. v. 308, p. 1023-1028, 2005.

[40] PARK, S. Y. et al. Reconstruction of the chemotaxis aceptor-kinase assembly. Nature Structural \& Molecular Biology, v. 13, p. 400-407, 2006.

[41] EPS, N. V. et al. Structural and dynamical changes in an $\alpha$-subunit of a heterotrimeric $G$ protein along the activation pathway. Proceedings of the National Acadamy Science, v. 103, p. 16194-16199, 2006.

[42] MARSH, D.; HORVÄTH, L. I. Structure, dynamics and composition of the lipid-protein interface. Perspectives from spin-labelling. Biochimica et Biophysica Acta, v. 1376, p. 267-296, 1998.

[43] CITADINI, A. P. S. EPR studies of chlorocatechol 1,2-dioxygenase: Evidences of iron reduction during catalysis and of the binding of amphipatic molecules. Biophysical Journal, v. 88, p. 3502-3508, 2005. 
[44] COSTA-FILHO, A. J.; SHIMOYAMA, Y.; FREED, J. H. A 2D-ELDOR study of the liquid ordered phase in multilamellar vesicle membranes. Biophysical Journal, v. 84, p. 2619-2633, 2003.

[45] COLLADO, M. I. et al. Domain formation in sphingomyelin/cholesterol mixed membranes studied by spin-label electron spin resonance spectroscopy. Biochemistry, v. 44, p. 4911-4918, 2005.

[46] GE, M. T. et al. Electron spin resonance characterization of liquid ordered phase of detergent-resistant membranes from RBL-2H3 cells. Biophysical Journal, v. 77, p. 925-933, 1999.

[47] FUNDECCITRUS. Estatísticas CVC. Disponível em: <www.fundeccitrus.com.br> Acesso em: 15 de Dezembro de 2005.

[48] TAKASHIMA, E. et al. Characterization of the dihydroorotate dehydrogenase as a soluble fumarate reductase in Trypanosoma cruzi. Molecular \& Biochemical Parasitology, v. 122, p. 189-200, 2002.

[49] INAOKA, D.K. et al. Expression, purification and crystallization of Trypanosoma cruzi dihydroorotate dehydrogenase complexed with orotate. Acta Crystallographica, v. F61, p. 875-878, 2005.

[50] KELLY, S. M.; PRICE, N. C. The application of circular dichroism to studies of protein folding and unfolding. Biochemica et Biophysica Acta, v. 1338, p. 161-185. 1997.

[51] FRONCISZ, W.; HYDE, J. S. The loop-gap resonator - a new microwave lumped circuit electron-spin-resonance sample structure J. S. Journal of Magnetic Resonance, v. 47, p. 515-521, 1982.

[52] FRAZIER, A. A. et al. Membrane orientation and position of the C2 domain from cPLA2 by site-directed spin labeling. Biochemistry, v. 41, p. 6282-6292, 2002.

[53] ALTENBACH, C. et al. Strucutural studies on transmembrane proteins. 2. Spin labeling of Bacteriorhodopsin mutants at unique cysteines. Biochemistry, v. 28, p. 7806-7812, 1989.

[54] MARGITTAI, M.; LANGEN, R. Spin labeling analysis of amyloids and other protein aggregates. Methods in Enzymology, v. 413, p. 122-139, 2006. 
[55] FANUCCI, G. E.; CAFISO, D. S. Recent advances and applications of site-directed spin labeling. Current Opinion in Structural Biology, v. 16, p. 644-653, 2006.

[56] LARSEN, J. N.; JENSEN, K. J. Nucleotide sequence of the pyrD gene of Escherichia coli and characterization of the flavoprotein dihydroorotate dehydrogenase. European Journal of Biochemistry, v. 151, p. 59-65, 1985.

[57] DELANO SCIENTIFIC LLC. Pymol. Disponível em: <http://pymol.sourceforge.net> Acesso em: 03 de Março de 2006.

[58] RAWLS, J. et al. Requirements for the mitochondrial import and localization of dihydroorotate dehydrogenase. European Journal of Biochemistry, v. 267, p. 2079-2087, 2000.

[59] SHI, J. et al. Multiple states of the Tyr318Leu mutant of dihydroorotate dehydrogenase revealed by single-molecule kinetics. Journal of the American Chemical Society, v. 126, p. 6914-6922, 2004.

[60] AUSUBEL, F. et al. Introduction of plasmid DNA into cells. In: Short Protocols in Molecular Biology. 3. ed. New York: John Wiley \& Sons, 1995. p. 1.21-1.22.

[61] BRADFORD, M. M. A rapid and sensitive method for the quantitation of microgram quantities of protein utilizing the principle of protein-dye binding. Analytical Biochemistry, v. 72, p. 248-254, 1976.

[62] LÓPEZ, O. et al. Direct formation of mixed micelles in the solubilization of phospholipid liposomes by Triton X-100. FEBS Letters, v. 426, p. 314-318, 1998.

[63] KRAGH-HANSEN, U.; MAIRE, M.; MOLLER, J. V. The mechanism of detergent solubilization of liposomes and protein-containing membranes. Biophysical Journal, v. 75 , p. 2932-2946, 1998.

[64] KUSNETZOW, A. K.; ALTENBACH, C.; HUBBELL, W. L. Conformational states and dynamics of rhodopsin in micelles and bilayers. Biochemistry, v. 45, p. 5538-5550, 2006.

[65] SAMBROOK, J.; FRITSCH, E. F.; MANIATS, T. in: Molecular Cloning a Laboratory Manual, 2. ed. New York: Cold Spring Harbor Laboratory Press, 1989. Apendix A. 
[66] CORPET, S. Multiple sequence alignment with hierarchical clustering. Disponivel em: <http://bioinfo.genopole-toulouse.prd.fr/multalin/multalin.html>. Acesso em: 12 de Julho de 2007.

[67] NIELSEN, F. S. et al. Purification and characterization of dihydroorotate dehydrogenase A from Lactococcus Zactis, crystallization and preliminary X-ray diffraction studies of the enzyme. Protein Science, v. 5, p. 252-256, 1996.

[68] KNECHT, W. et al. Functional expression of a fragment of human dihydroorotate dehydrogenase by means of the baculovirus expression vector system, and kinetic investigation of the purified recombinant enzyme. European Journal of Biochemistry, v. 240, p. 292-301, 1996.

[69] HINES, V.; KEYS, L. D. I.; JOHNSTON, M. Purification and properties of the bovine liver mitochondrial dihydroorotate dehydrogenase. Journal of Biological Chemistry, v. 261, p. 11386-11392, 1986.

[70] DAVIS, J. P. et. al. The immunosuppressive metabolite of leflunomide is a potent inhibitor of human dihydroorotate dehydrogenase. Biochemistry, v. 35, p. 1270$1273,1996$.

[71] JOST, P. C. et al. Evidence for boundary lipid in membranes. Proceedings of the National Academy Science, v. 70, p. 480-484, 1973.

[72] KANG, S. Y. et al. Nuclear magnetic resonance investigations of the cytochrome oxidase-phospholipid interaction: a new model for boundary lipid. Biochemistry, v. 18, p. 257-3267, 1979.

[73] FREED, J. H. Theory of slow tumbing ESR spectra for nitroxides. In: Lawrence, J.; Berliner, L. J.. Spin Labeling Theory and Applications. Nova York: Academic Press, 1976. cap. 3, p. 53-130.

[74] SCHNEIDER, D. J.; FREED, J. H. Calculating slow motional magnetic resonance spectra: a user's guide. In: Biological Magnetic Resonance. New York: Plenum Publishing Corp. 1989. V. 8, cap. 1, p. 1-76.

[75] FERRARINI, A. et al. A theoretical-model of phospholipid dynamics in membranes. Journal of Chemical Physics, v. 91, p. 5707-5721, 1989.

[76] RISKE K. A. et al. Temperature and ionic strength dependent light scattering of DMPG dispersions. Chemistry and Physics of Lipids, v. 89, p. 31-44, 1997. 
[77] GE, M.; RANANAVARE, S. B.; FREED, J. H. ESR studies of stearic-acid binding to bovine serum-albumin. Biochimica Biophysica Acta, v. 1036, p. 228-236, 1990.

[78] MARSH, D. Polarity and permeation profiles in lipid membranes. Proceedings of the Natlional Academy of Sciences, v. 98, p. 7777-7782, 2001.

[79] GRIFFITH, O. H.; JOST, P. A. Lipid spin labels in biological membranes. In: BERLINER, L. J. Spin Labeling: Theory and Applications. New York: Academic Press, 1976, p. 453-523.

[80] GASTEIGER, E. et al. Protein identification and analysis tools on the ExPASy server in: John M. W. The Proteomics Protocols Handbook. Totowal: Copyright Humana Press, 2005. p 571-607.

[81] KAR, L.; NEY-IGNER, E.; FREED, J. H. Electron spin resonance and electron-spinecho study of oriented multilayers of $L_{\alpha}$-dipalmitoylphosphatidylcholine water system. Biophysical Journal, v. 48, p. 569-595, 1985.

[82] SHIN, Y. K.; FREED, J. H. Thermodynamics of phosphatidylcholine-cholesterol mixed model membranes in the liquid crystalline state studied by the orientational order parameter. Biophysical Journal, v. 56, p. 1093-1100, 1989.

[83] GE, M.; FREED, J. H. Electron-spin resonance study of aggregation of Gramicidin in dipalmitoylphosphatidylcholine bilayers and hydrophobic mismatch. Biophysical Journal, v. 76, p. 264-280, 1999.

[84] KLEINSCHMIDT, J. H. et al. Interaction of bee venom melittin with zwitterionic and negatively charged phospholipid bilayers: A spin-label electron spin resonance study. Biophysical Journal, v. 72, p. 767-778, 1997.

[85] GE, M. T. et al. ADP ribosylation factor 6 binding to phosphatidylinositol 4,5bisphosphate-containing vesicles creates defects in the bilayer structure: An electron spin resonance study. Biophysical Journal, v. 81, p. 994-1005, 2001.

[86] GE, M. T. et al. Ordered and disordered phases coexist in plasma membrane vesicles of RBL-2H3 mast cells an ESR study. Biophysical Journal, v. 85, p. 1278-1288, 2003.

[87] STOPAR, D. et al. Exploring the local conformational space of a membrane protein by site-directed spin labeling. Journal of Chemical Information Modeling, v. 45, p. 1621-1627, 2005. 
[88] PISTOLESI, S. et al. Molecular motion of spin labeled side chains in the C-terminal domain of RGL2 protein: A SDSL-EPR and MD study. Biophysical Chemistry, v. 123, p. 49-57, 2006.

[89] MCHAOURAB, H. S. et al. Motion of spin-labeled side chains in T4 lysozyme. correlation with protein structure and dynamics. Biochemistry, v. 35, p. 7692-7704, 1996.

[90] MCHAOURAB, H. S. et al. Motion of spin-labeled side chains in T4 lisozyme: effect of side chain structure. Biochemistry, v. 38, p. 2947-2955, 1999.

[91] GUO, Z. et al. Structural determinants of nitroxide motion in spin-labeled proteins: tertiary contact and solvent-inaccessible sites in helix G of T4 lysozyme, Protein Science, v. 16, p. 1069-1086, 2007.

[92] LOVELL, S. C. et al. The penultimate rotamer library. Proteins-Structure Function and Genetics, v. 40, p. 389-408, 2000.

[93] LANGEN, R. et al. Crystal structures of spin labeled T4 lysozyme mutants: implications for the interpretation of EPR spectra in terms of structure. Biochemistry, v. 39, p. 8396-8405, 2000.

[94] VAN WART, H. E.; SCHERAGA, H. A. Stable conformations of aliphatic disulfides: Influence of 1,4 interactions involving sulfur atoms. Proceedings of the National Academy Science, v. 74, p. 13-17, 1977.

[95] ROSENFIELD, R. E.; PARTHASARATHY, R.; DUNITZ, J. D. Directional preferences of nonbonded atomic contacts with divalent sulfur. 1. Electrophiles and nucleophiles. Journal of the Americam Chemistry Society, v. 99, p. 4860-4862, 1977.

[96] NAGAO, Y. et al. Intramolecular nonbonded S-O interaction recognized in (acylimino)thiadiazoline derivatives as angiotensin II aceptor antagonists and related compounds. Journal of the Americam Chemistry Society, v. 120, p. 3104-3110, 1998.

[97] FRASER, R. R. Barriers to rotation about the sulfur-sulfur bond in acyclic disulfides, Journal of the Americam Chemistry Society, v. 93, p. 3822-3823, 1971.

[98] JIAO, D. et al. Ab initio molecular orbital studies of the rotational barriers and the sulphur-33 and carbon-13 chemical shieldings for dimethyl disulfide, Journal of the Americam Chemistry Society, v. 114, p. 3639-3643, 1992.

[99] DE NEGRI, J. D.; GARCIA JUNIOR, A. Sugestões para o manejo de pomares com clorose variegada dos citros. Laranja, v. 14, p. 255-67, 1993. 
[100] PREJUÍZOS com a CVC. Informativo CCSM. v. 6, p. 3, 2001. Disponível em: <http://www.centrodecitricultura.br>. Acesso em: 09 de Novembro de 2001.

[101] LARANJEIRA, F. F. et al. Dinâmica temporal da clorose variegada dos citros em três regiões do estado de São Paulo. Fitopatologia Brasileira, v. 28, p. 481-488, 2003.

[102] PURCELL, A. University of California. Disponível em: <www.Bugwood.org>. Acesso em: 21 de Junho de 2004.

[103] ROBERTO, S. R. et al. Transmissão de Xylella fastidiosa pelas cigarrinhas Dilobopterus costalimai, Acrogonia terminalis e Oncometopia facialis (Hemiptera: Cicadellidae) em citros. Fitopatologia Brasileira, v. 21, p. 517-518, 1996.

[104] LEE, R. F. et al. Development of a serological assay for citrus variegated chlorosis - a new disease of citrus in Brazil. Proceedings of the Florida State Horticultural Society, v. 105, p. 32-34, 1992.

[105] SIMPSON, et al. The genome sequence of the plant pathogen Xylella fastidiosa. Nature v. 406, p. 151-157, 2000.

[106] NATIONAL Center for Biotechnology Information - NCBI. Disponível em: <http://www.ncbi.nlm.nih.gov>. Acesso em 11 de Março de 2004.

[107] SANT'ANNA, O. A. Immunology in Brazil: historical fragments. 2007 Scandinavian Journal of Immunology, v. 66, p. 106-112, 2007.

[108] CAMANDAROBA, E. L.; PINHEIRO LIMA, C. M.; ANDRADE, S, G. Oral transmission of Chagas disease: importance of Trypanosoma cruzi biodeme in the intragastric experimental infection. Revista do Instituto de Medicina Tropical de Sao Paulo, v. 44, p. 97-103, 2002.

[109] WORLD Health Organization. Control of Chagas Disease. Geneva, p. 109. Disponível em: <http://www.who.int>. Acesso em: 07 de Novembro de 2003.

[110] GELB, M. H.; HOL, W. G. J. Parasitology - Drugs to combat tropical protozoan parasites. Science, v. 297, p. 343-344, 2002.

[111] MOREL, C. M. Reaching maturity - 25 Years of the TDR. Parasitology Today, v. 16, p. 522-525, 2000. 
[112] VINHAES, M. C.; SCHOFIELD, C. J. Trypanosomiasis control: surmounting diminishing returns. Trends in Parasitology, v. 19, p. 112-113, 2003.

[113] LAURIA-PIRES, L. et al. Progressive chronic chagas disease ten years after treatment with anti-Trypanosoma cruzi nitroderivatives. American Journal of Tropical Medicine and Hygiene, v. 63, p. 111-118, 2000.

[114] URBINA, J. A. Specific treatment of chagas disease: current status and new developments. Current Opinion in Infectuous Diseasis, v. 14, p. 733-741, 2001

[115] VIOTTI, R. et al. Treatment of chronic Chagas disease with benznidazole: clinical and serologic evolution of patients with longterm follow-up. American Heart Journal, v. 127, p. 151-162, 1994.

[116] COURA, J. R.; CASTRO, S. L. A critical review on chagas disease chemotherapy. Memórias do Instituto Oswaldo Cruz, v. 97, p. 3-24, 2002.

[117] DOCAMPO, R. Recent developments in the chemotherapy of chagas disease. Current Pharmaceutical Design, v. 7, p. 1157-1164, 2001.

[118] NARA, T. et al. Inhibitory action of marine algae extracts on the Trypanosoma cruzi dihydroorotate dehydrogenase activity and on the protozoan growth in mammalian cells. Parasitology International, v. 54, p. 59-64, 2005.

[119] GUTTERIDGE, W. E.; GABORAK, M. Re-examination of purine and pyrimidine synthesis in these main forms of Trypanosoma cruzi. International Journal of Biochemistry, v. 10, p. 415-422, 1979.

[120] ANNOURA T. et al. The origin of dihydroorotate dehydrogenase genes of kinetoplastides, with special reference to their biological significance and adaptation to anaerobic parasitic conditions. Journal of Molecular Evolution, v. 60, p. 113127, 2005.

[121] PINHEIRO, M. P. Estudos cristalográficos da enzima diidroorotato desidrogenase de Trypanosoma cruzi. 2008, 106 f. Dissertação (mestrado em Farmácia) - Faculdade de Ciências Farmacêuticas, Universidade de São Paulo, Ribeirão Preto, 2008.

[122] PINHEIRO, M. P.; IULEK, J.; NONATO, M. C. Crystal structure of T. cruzi DHODH from $Y$ strain. Biochemical Biophysical Research Communications. In press 
[123] WOODY, R.; BEROVA, N.; NAKANISHI, K. Circular dichroism: Principles and applications. New York: VCH Publishers, 1994. 570 p.

[124] MANNING, M. C. Protein structure and stability assesment by circular dichroism spectroscopy. In: HIMMEL, M. E.; GEORGIOU, G. Biocatalyst design for stability and specificity. Oxford: ACS Symposium series. 1992. V. 516. pp 33-52.

[125] TOWELL, J. F.; MANNING, M. C. Analysis of protein structure by circular dichroism spectroscopy. In: PURDIE, N.; BRITTAIN, H. G. Analytic applications of circular dichroism. New York: Elsevier Sciences B. V. 1994. pp 175-205.

[126] SÁNCHEZ-RUIZ, J. M. et al. Differential scanning calorimetry of the irreversible thermal denaturation of thermolysin, Biochemistry, v. 27, p. 1648-1652, 1988. 
Apêndice 


\section{Apêndice $A$ \\ Parâmetros cristalográficos dos resíduos mutados da EcDHODH}

\begin{tabular}{|c|c|c|c|c|c|c|c|c|c|c|}
\hline & & & & & & $X(\AA)$ & $Y(\AA)$ & $Z(\AA)$ & Oc. & $B\left(\AA^{2}\right)$ \\
\hline ATOM & 9 & $\mathrm{~N}$ & TYR & $\mathrm{A}$ & 2 & 83.744 & -11.726 & 41.524 & 1.00 & 50.63 \\
\hline ATOM & 10 & $\mathrm{CA}$ & TYR & A & 2 & 83.584 & -10.327 & 41.824 & 1.00 & 48.28 \\
\hline ATOM & 11 & $\mathrm{C}$ & TYR & A & 2 & 84.581 & -9.547 & 40.973 & 1.00 & 46.39 \\
\hline ATOM & 12 & 0 & TYR & A & 2 & 85.795 & -9.664 & 41.164 & 1.00 & 45.81 \\
\hline ATOM & 13 & $\mathrm{CB}$ & TYR & $\mathrm{A}$ & 2 & 83.871 & -10.136 & 43.308 & 1.00 & 48.81 \\
\hline ATOM & 14 & CG & TYR & A & 2 & 83.426 & -8.819 & 43.880 & 1.00 & 49.39 \\
\hline ATOM & 15 & $\mathrm{CD} 1$ & TYR & A & 2 & 82.123 & -8.363 & 43.693 & 1.00 & 48.5 \\
\hline ATOM & 16 & $\mathrm{CD} 2$ & TYR & A & 2 & 84.293 & -8.047 & 44.651 & 1.00 & 50.7 \\
\hline ATOM & 17 & $\mathrm{CE} 1$ & TYR & A & 2 & 81.692 & -7.170 & 44.260 & 1.00 & 49.9 \\
\hline ATOM & 18 & $\mathrm{CE} 2$ & TYR & A & 2 & 83.872 & -6.850 & 45.229 & 1.00 & 49.9 \\
\hline ATOM & 19 & $\mathrm{CZ}$ & TYR & A & 2 & 82.570 & -6.420 & 45.028 & 1.00 & 50.9 \\
\hline ATOM & 20 & $\mathrm{OH}$ & TYR & A & 2 & 82.138 & -5.242 & 45.594 & 1.00 & 53.7 \\
\hline ATOM & 40 & $\mathrm{~N}$ & PHE & $\mathrm{A}$ & 5 & 87.889 & -7.885 & 42.231 & 1.00 & 38.99 \\
\hline ATOM & 41 & $\mathrm{CA}$ & PHE & A & 5 & 89.033 & -8.752 & 42.482 & 1.00 & 40.00 \\
\hline ATOM & 42 & C & PHE & A & 5 & 89.712 & -9.031 & 41.151 & 1.00 & 38.88 \\
\hline ATOM & 43 & 0 & PHE & A & 5 & 90.937 & -9.108 & 41.069 & 1.00 & 38.7 \\
\hline ATOM & 44 & $\mathrm{CB}$ & PHE & A & 5 & 88.589 & -10.062 & 43.144 & 1.00 & 43.8 \\
\hline ATOM & 45 & CG & PHE & A & 5 & 88.293 & -9.933 & 44.619 & 0.80 & 48.40 \\
\hline ATOM & 46 & $\mathrm{CD} 1$ & PHE & $\mathrm{A}$ & 5 & 88.384 & -8.699 & 45.261 & 0.80 & 50.40 \\
\hline ATOM & 47 & $\mathrm{CD} 2$ & PHE & A & 5 & 87.927 & -11.047 & 45.368 & 0.80 & 50.47 \\
\hline ATOM & 48 & $\mathrm{CE} 1$ & PHE & $\mathrm{A}$ & 5 & 88.116 & -8.578 & 46.625 & 0.80 & 51.9 \\
\hline ATOM & 49 & $\mathrm{CE} 2$ & PHE & $\mathrm{A}$ & 5 & 87.656 & -10.938 & 46.733 & 0.80 & 51.18 \\
\hline AтOM & 50 & $\mathrm{CZ}$ & PHE & A & 5 & 87.752 & -9.701 & 47.362 & 0.80 & 51.97 \\
\hline ATOM & 164 & $\mathrm{~N}$ & HIS & $\mathrm{A}$ & 19 & 95.271 & -6.607 & 28.716 & 1.00 & 21. \\
\hline ATOM & 165 & $\mathrm{CA}$ & HIS & $\mathrm{A}$ & 19 & 94.299 & -6.726 & 27.657 & 1.00 & 22.0 \\
\hline ATOM & 166 & $\mathrm{C}$ & HIS & $\mathrm{A}$ & 19 & 94.529 & -8.027 & 26.885 & 1.00 & 22.0 \\
\hline ATOM & 167 & 0 & HIS & A & 19 & 93.577 & -8.738 & 26.569 & 1.00 & 19.6 \\
\hline ATOM & 168 & $\mathrm{CB}$ & HIS & A & 19 & 94.395 & -5.521 & 26.722 & 1.00 & 21.7 \\
\hline ATOM & 169 & CG & HIS & $\mathrm{A}$ & 19 & 93.638 & -5.700 & 25.448 & 1.00 & 22.8 \\
\hline ATOM & 170 & ND1 & HIS & A & 19 & 94.202 & -6.253 & 24.319 & 1.00 & 22.6 \\
\hline ATOM & 171 & CD2 & HIS & $\mathrm{A}$ & 19 & 92.336 & -5.474 & 25.149 & 1.00 & 22.2 \\
\hline ATOM & 172 & $\mathrm{CE} 1$ & HIS & A & 19 & 93.280 & -6.362 & 23.378 & 1.00 & 23.5 \\
\hline ATOM & 173 & $\mathrm{NE} 2$ & HIS & A & 19 & 92.140 & -5.897 & 23.858 & 1.00 & 23.5 \\
\hline ATOM & 183 & $\mathrm{~N}$ & PHE & A & 21 & 95.898 & -10.773 & 27.929 & 1.00 & 25.7 \\
\hline ATOM & 184 & $\mathrm{CA}$ & PHE & A & 21 & 95.533 & -11.906 & 28.769 & 1.00 & 24 \\
\hline ATOM & 185 & $\mathrm{C}$ & PHE & $\mathrm{A}$ & 21 & 94.019 & -12.076 & 28.759 & 1.00 & 23.91 \\
\hline ATOM & 186 & 0 & PHE & A & 21 & 93.503 & -13.188 & 28.628 & 1.00 & 23.9 \\
\hline ATOM & 187 & $\mathrm{CB}$ & PHE & A & 21 & 95.992 & -11.676 & 30.208 & 1.00 & 25.8 \\
\hline ATOM & 188 & CG & PHE & A & 21 & 95.582 & -12.768 & 31.153 & 1.00 & 27.2 \\
\hline ATOM & 189 & $\mathrm{CD} 1$ & PHE & A & 21 & 96.288 & -13.967 & 31.207 & 1.00 & 28. \\
\hline ATOM & 190 & $\mathrm{CD} 2$ & PHE & $\mathrm{A}$ & 21 & 94.481 & -12.605 & 31.984 & 1.00 & 27.4 \\
\hline ATOM & 191 & CE1 & PHE & A & 21 & 95.900 & -14.988 & 32.081 & 1.00 & 29.1 \\
\hline ATOM & 192 & $\mathrm{CE} 2$ & PHE & $\mathrm{A}$ & 21 & 94.085 & -13.622 & 32.859 & 1.00 & 29. \\
\hline ATOM & 193 & $\mathrm{CZ}$ & PHE & A & 21 & 94.797 & -14.813 & 32.907 & 1.00 & 26.8 \\
\hline
\end{tabular}




\title{
Apêndice B
}

\section{Defects in Vesicle Core Induced by Escherichia coli Dihydroorotate Dehydrogenase}

\author{
Sheila G. Couto, ${ }^{*}$ M. Cristina Nonato, ${ }^{\dagger}$ and Antonio J. Costa-Filho* \\ *Grupo de Biofísica Molecular Sérgio Mascarenhas, Instituto de Física de São Carlos, Universidade de São Paulo, 13560-970, São Carlos, \\ SP, Brazil; and 'Laboratório de Cristalografia de Proteínas, Faculdade de Ciências Farmacêuticas de Ribeirão Preto, Universidade de \\ São Paulo, 14040-903, Ribeirão Preto, SP, Brazil
}

\begin{abstract}
Dihydroorotate dehydrogenase $(\mathrm{DHODH})$ catalyzes the oxidation of dihydroorotate to orotate during the fourth step of the de novo pyrimidine synthesis pathway. In rapidly proliferating mammalian cells, pyrimidine salvage pathway is insufficient to overcome deficiencies in that pathway for nucleotide synthesis. Moreover, as certain parasites lack salvage enzymes, relying solely on the de novo pathway, DHODH inhibition has turned out as an efficient way to block pyrimidine biosynthesis. Escherichia coli DHODH (EcDHODH) is a class $2 \mathrm{DHODH}$, found associated to cytosolic membranes through an $\mathrm{N}$-terminal extension. We used electronic spin resonance (ESR) to study the interaction of EcDHODH with vesicles of 1,2-dioleoyl-sn-glycero-phosphatidylcholine/detergent. Changes in vesicle dynamic structure induced by the enzyme were monitored via spin labels located at different positions of phospholipid derivatives. Two-component ESR spectra are obtained for labels 5- and 10-phosphatidylcholine in presence of EcDHODH, whereas other probes show a single-component spectrum. The appearance of an additional spectral component with features related to fast-motion regime of the probe is attributed to the formation of a defect-like structure in the membrane hydrophobic region. This is probably the mechanism used by the protein to capture quinones used as electron acceptors during catalysis. The use of specific spectral simulation routines allows us to characterize the ESR spectra in terms of changes in polarity and mobility around the spin-labeled phospholipids. We believe this is the first report of direct evidences concerning the binding of class $2 \mathrm{DHODH}$ to membrane systems.
\end{abstract}

\section{INTRODUCTION}

Growing organisms need nucleotides, the building blocks of DNA, RNA, and other biologically essential molecules. Inhibitors of nucleotide synthesis form an important group of chemotherapeutic agents, and cells that rely on this pathway are especially susceptible to such inhibitors. The de novo pyrimidine pathway seems to be significantly important. Besides RNA and DNA synthesis, pyrimidines are also needed for protein glycosylation, membrane lipid biosynthesis, and strand break repair (1-23). Several inhibitors of the enzyme involved in the only redox step of pyrimidines nucleotide pathway, dihydroorotate dehydrogenase (DHODH), have been in clinical trials and one inhibitor, Arava (leflunomide; Sigma, St. Louis, MO), has been approved for human use as rheumatoid arthritis agent $(4,5)$. In addition, the increased interest in DHODH is due to its role as a target for a number of biologically active chemical or natural compounds. The enzyme has been identified as a pharmacological target for isoxazole, triazine, cinchoninic acid and (naphtha)quinone derivatives, which exerted antiproliferative, immunosuppressive, and antiparasitic effects (6-8). These compounds were found to interfere with aberrant imunological reactions, to combat parasitic protozoa infections, like malaria, to pre-

Submitted August 17, 2007, and accepted for publication October 10, 2007. Address reprint requests to Antonio J. Costa-Filho, Grupo de Biofísica Molecular Sérgio Mascarenhas, Instituto de Física de São Carlos, Universidade de São Paulo, Av. Trabalhador São-carlense, 400, C.P. 369, CEP 13560-970São Carlos, SP, Brazil. Tel./Fax: 55-16-3371-5381. E-mail: ajcosta@ if.sc.usp.br.

Editor: David D. Thomas.

(C) 2008 by the Biophysical Society 0006-3495/08/03/1746/08 \$2.00 vent the spreading of animal parasitic diseases, and to support antiviral therapies, by lowering the intracellular concentrations of pyrimidine nucleotides (9).

Dihydroorotate dehydrogenase catalyses the fourth sequential step in the de novo pyrimidine nucleotide synthesis pathway with the oxidation of dihydroorotate to orotate, the first aromatic intermediate in this biosynthetic pathway, with the aid of a flavin cofactor and an electron receptor (1). On the basis of sequence similarity, the DHODHs can be divided in two major classes (2). This division correlates with subcellular location of the proteins as well as their preferences for electron acceptors. Enzymes of class 1, found in Grampositive bacteria and in the anaerobic yeast Saccharomyces cerevisiae, are located in the cytosol of the cell. They share $<20 \%$ sequence identity with the membrane-bound enzymes of class 2 , found in eukaryotes and in some prokaryotes such as the Gram-negative bacteria related to Escherichia coli. Class 1 enzymes can be further divided into two subtypes, namely $1 \mathrm{~A}$ and $1 \mathrm{~B}$. The eukaryotic class 2 enzymes are located in the inner membrane of mitochondria and, in the case of E. coli enzyme, are associated with the cytoplasmatic membrane.

The structure of DHODH has been solved for four different organisms: Homo sapiens (HsDHODH) (10), E. coli (EcDHODH) (11), rat (12), Plasmodium falciparum (13), and Lactococcus lactis $(3,14,15)$. The latter includes subtypes A and B of class 1 DHODHs. In all cases the structure of DHODH is an $\alpha / \beta$ barrel with eight parallel $\beta$ strands forming the barrel and $\alpha$ helices wrapped around the outside. The orotate active site is at the top of the barrel where several 
additional strands form a binding pocket for the flavin cofactor and orotate. In addition to this main barrel, class 2 DHODH, such as HsDHODH and EcDHODH, contains a second domain situated at the $\mathrm{N}$-terminus, which is supposed to be involved with membrane interaction (11).

Another remarkable difference between the two classes of DHODH is related to the mechanism used by them to complete the redox reaction. In class 1 DHODHs, the electron acceptors involved in the second half reaction of the redox process are either fumarate or $\mathrm{NAD}^{+}(1)$ whereas for class 2 DHOHDs this role is played by quinones present in the biological membranes $(16,17)$. In the latter case, the $\mathrm{N}$ terminus has been proposed as the binding site for the electron acceptor (10). Thus, this $\mathrm{N}$-terminal domain is supposedly responsible for both membrane association and binding of electron acceptor molecules.

Electron spin resonance (ESR) is a powerful technique that makes use of either transition metal ions or spin probes, usually involving stable nitroxide radicals bound to molecules such as phospholipids or cysteine residues in proteins, to monitor changes in the probe vicinity (18-21). Some advantages of spin-labeling ESR experiments are the possibility of using a selective probe that has a simple ESR spectra and their high sensitivity to the molecular motion of the spinbearing moiety. The changes in the nitroxide surroundings can be related to a variety of biologically-relevant processes such as protein conformational changes (22-24), lipid-protein interactions (25-28), and the dynamic structure of biologic and model membranes (29-32).

In this article, we use ESR to monitor EcDHODH-induced changes in the neighborhood of spin-labeled phospholipids incorporated into a membrane model system. We address the main goal of investigating the effect of EcDHODH binding to phospholipid vesicles. The use of specific spectral simulation routines allows us to fully characterize the ESR spectra in terms of changes in polarity and mobility in the surroundings of the spin-labeled phospholipid molecules. To the best of our knowledge, this is the first report showing direct evidences concerning the binding of class 2 DHODH to membrane systems and its implication in protein function.

\section{MATERIALS AND METHODS}

\section{Expression and purification of EcDHODH}

PAG1 plasmid and E. coli cell strains used for EcDHODH expression were kindly provided by Prof. K. F. Jensen (University of Copenhagen) (33). E. coli $\mathrm{DHODH}$ was overexpressed in $\mathrm{S} 06645 \mathrm{E}$. coli cell strain grown in Luria-Broth medium. A cell pellet from $250 \mathrm{~mL}$ of cell culture was lysed in $10 \mathrm{~mL}$ of $50 \mathrm{mM}$ sodium phosphate buffer $\mathrm{pH} 8.0$ and $0.25 \mathrm{mM}$ EDTA. To the ly sate was added $5 \mathrm{mM}$ magnesium chloride plus $0.2 \%$ Triton X-100 with subsequent centrifugation at $17,200 \times g$ for $1 \mathrm{~h}$. The supernatant was applied to a $20 \mathrm{~mL}$ DEAE-Sepharose column (Amersham Biosciences, Uppsala, Sweden) equilibrated with $50 \mathrm{mM}$ sodium phosphate buffer $\mathrm{pH} 8.0$ and $0.25 \mathrm{mM}$ EDTA. The column was washed with $50 \mathrm{~mL}$ sodium phosphate buffer $\mathrm{pH} 8.0,0.1 \mathrm{mM}$ EDTA and $0.1 \%$ Triton X-100 and eluted with a linear gradient from 0 to $1 \mathrm{M} \mathrm{NaCl}$. The fractions containing EcDHODH were combined in presence of $0.5 \%$ Triton X-100, followed by $1 \mathrm{M}$ ammonium sulfate precipitation. The mixture was incubated for $1 \mathrm{~h}$ at $4^{\circ} \mathrm{C}$ and centrifuged at $20,000 \times g$ for $1 \mathrm{~h}$. The supernatant was applied to a $2 \mathrm{~mL}$ PhenylSepharose column (Amersham Biosciences) equilibrated with $50 \mathrm{mM}$ sodium phosphate buffer $\mathrm{pH} 7.0,0.1 \mathrm{mM}$ EDTA and $1.1 \mathrm{M}$ ammonium sulfate. The column was washed with a linear gradient from 1.1 to $0 \mathrm{M}$ ammonium sulfate. The protein is eluted with $50 \mathrm{mM}$ sodium phosphate buffer $\mathrm{pH} 7.0$, 0.1 mM EDTA and $0.5 \%$ Triton X-100.

\section{EcDHODH/vesicles mixtures}

EcDHODH is purified in the presence of the detergent Triton X-100, which is crucial for enzyme solubilization. The absence of the detergent leads to protein precipitation probably due to aggregation via its N-terminal domain. The solution containing EcDHODH in the presence of Triton X-100 is added to a dried phospholipid film formed on the wall of a glass tube from chloroform stock solutions of the lipid. It is well-known that the mixture of surfactants to phospholipids leads to alterations in the membrane structure, which depend basically on the ratio surfactant/phospholipids $(34,35)$. A continuous increase in such a ratio is accompanied by a transition from a bilayer to a monolayer structure. In our case, the detergent Triton X-100 comes from the purification/solubilization process and its final concentration is hard to determine exactly. Several assays with different detergent concentration were carried out to assure that the amount of detergent present in the final samples was the minimum required for protein solubilization. In this work, final Triton X-100 concentration is above its critical micelle concentration and we estimated the surfactant/phospholipid ratio to be close to 1 , which resulted in a mixture of mixed micelles and mixed vesicles described by López et al. (34) for a system constituted by Triton X-100 and phosphatidylcholine. To have a control experiment, enzyme-free samples containing mixtures of Triton X-100 and phospholipids at similar surfactant/ phospholipid ratio as before were prepared and submitted to ESR analysis.

\section{ESR spectroscopy}

The headgroup spin label dipalmitoylphosphatidyl tempo (2,2,6,6,-tetramethyl1-oxy) choline (DPPTC), the phospholipid labels 1-palmitoyl-2-(n-doxyl stearoyl) phosphatidylcholine $(\mathrm{n}=5,10,12,16-\mathrm{PC})$ and the lipid 1,2-dioleoyl-sn-glycero-phosphatidylcholine (DOPC) were purchased from Avanti Polar Lipids (Alabaster, AL). All labels and chemicals were used without further purification. Measured stock solutions of the lipid DOPC and the spin labels were mixed in a glass tube. The chloroform present in the stock solutions was removed by $\mathrm{N}_{2}$ flow followed by $1 \mathrm{~h}$ in a Speedvac system to ensure complete removal of the solvent. A measured amount of the buffered EcDHODH/Triton X-100 solution was added to the sample tube, and incubated for several minutes. A final volume of $100 \mu \mathrm{L}$ of the samples containing mixtures of EcDHODH/Triton X-100/DOPC/spin label was drawn into a quartz flat cell, which was in turn placed in the ESR resonant cavity. Final enzyme concentration ranged from 89-103 $\mu \mathrm{M}$. X-band ESR spectra of those samples were recorded on a Varian E109 spectrometer at room temperature. Acquisition conditions were: modulation amplitude, $1.0 \mathrm{G}$; modulation frequency, $100 \mathrm{kHz}$; microwave power, $10 \mathrm{~mW}$; field range, $100 \mathrm{G}$.

\section{RESULTS AND DISCUSSIONS}

\section{ESR spectra and nonlinear least-squares analysis}

The ESR spectra of the headgroup spin probe (DPPTC) as well as acyl chain labels (5-, 10-, 12- and 16-PC) incorporated into DOPC/Triton $\mathrm{X}-100$ mixed vesicles in the presence and absence of EcDHODH are shown in Fig. 1. Only minor changes between samples with and without EcDHODH are 


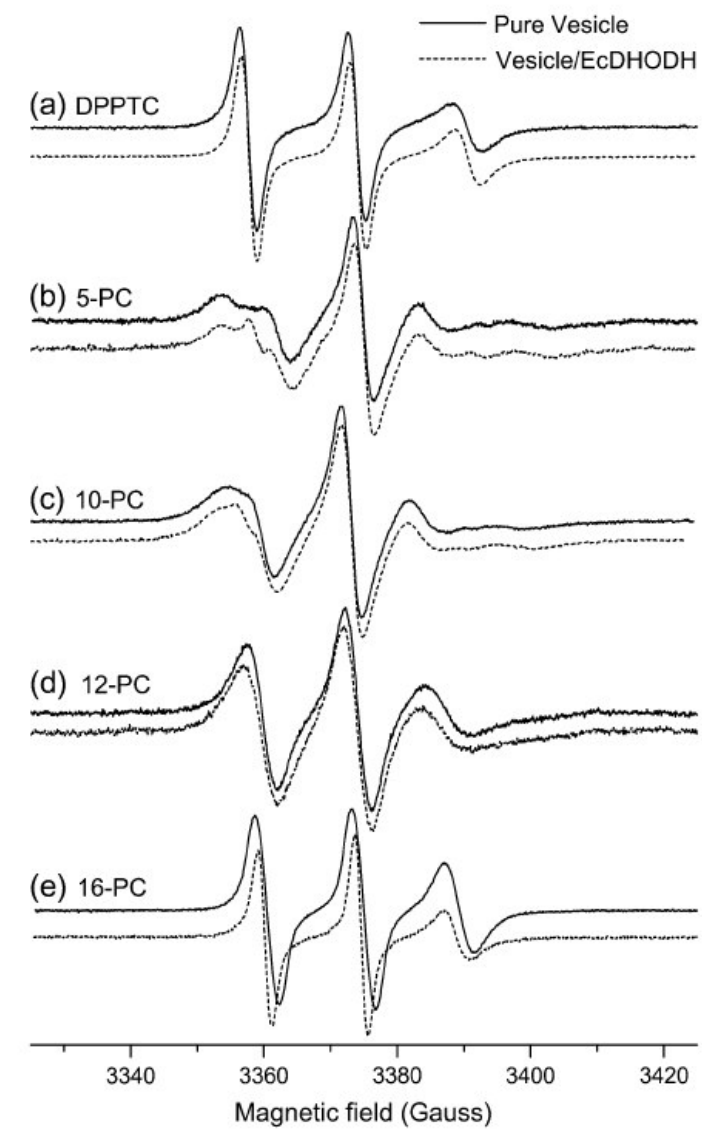

FIGURE 1 ESR spectra of spin labels (a) DPPTC, (b) 5-, (c) 10-, (d) 12-, and $(e)$ 16-PC incorporated into vesicles of DOPC/Triton X-100 in the absence (solid line) and in the presence of $\mathrm{ECDHODH}$ (dashed line). Experimental conditions: microwave frequency $9.5 \mathrm{GHz}$; modulation amplitude $1.0 \mathrm{G}$; modulation frequency $100 \mathrm{kHz}$; microwave power $10 \mathrm{~mW}$.

detectable for DPPTC, 12-, and 16-PC probes, whereas the appearance of a second component (sharp peak in the lowfield resonance) is observed for probes 5- and 10-PC in the presence of the titled enzyme. In these two-component spectra, the major contribution is attributed to the bulk labeled phospholipids whereas the second one is assigned to label molecules in close contact with the protein (the socalled boundary lipid (36-38)). A qualitative analysis of the extra component suggests that a spectrum constituted by sharp lines like those observed in Fig. $1 B$ and $C$ should be the result of a much less hindered motion of the spin probes when in the vicinity of the enzyme. The faster motion experienced by the boundary labels averages out the anisotropy of the magnetic interactions (hyperfine and Zeeman) leading to narrower resonance lines than usually observed for spin probes experiencing slow and anisotropic motion. A control experiment using class 1 Trypanosoma cruzi DHODH (TcDHODH), which misses the $\mathrm{N}$-terminal domain (cloning, expression, and purification of TcDHODH followed a protocol adapted from 39), in the presence of the same membrane model system described above yielded no alterations whatsoever in the ESR spectra of either the headgroup or a carbon-chain spin probe (data not shown).

To fully characterize the modifications measured in the presence of EcDHODH, the ESR spectra of the spin probes in mixtures of vesicle/enzyme were simulated by means of a nonlinear least-squares program developed by Freed et al. $(40-42)$. The parameters involved in the fitting procedure were as follows: hyperfine tensor components $\left(A_{\mathrm{xx}}, A_{\mathrm{yy}}, A_{\mathrm{zz}}\right)$, rotational diffusion rates $\left(R_{\perp}\right.$ and $\left.R_{/ /}\right)$, and a lorentzian $\left(1 / T_{2}^{*}\right)$ inhomogeneous broadening. The dynamics of the spin probe is characterized by $R_{\perp}$ and $R_{/ /}$, which represent the rotational diffusion rates of the nitroxide radical around the axes perpendicular and parallel to the mean symmetry axis for the rotation. This symmetry axis is also the direction of preferential orientation of the spin label moiety (41). For n-PC chain labels, $R_{\perp}$ accounts for the wagging motion of the long axis of the carbon chain (Fig. $2 A$ ). As for the label DPPTC, it represents the wagging motion of the headgroup region (Fig. $2 \mathrm{~B}$ ). To avoid local minima the simulation process was restarted from different sets of seed values.

The ESR spectra of the spin probes incorporated into the model membrane system (Fig. 3) can be divided, for

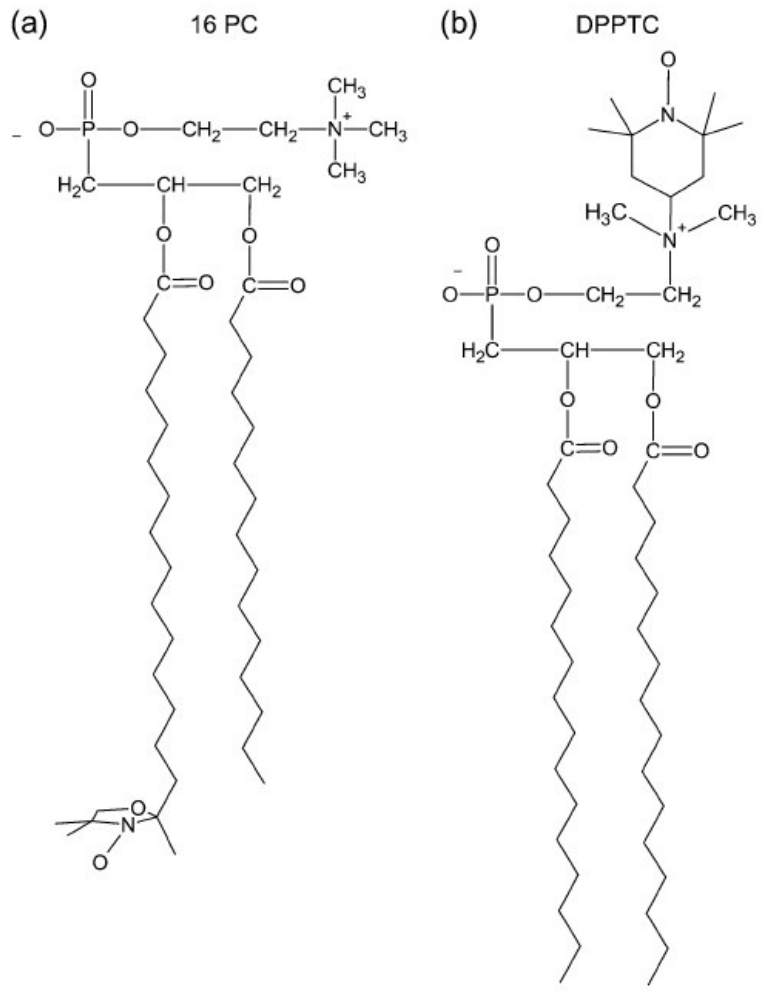

FIGURE 2 Chemical structures of the $(a)$ acyl-chain (16-PC) and (b) headgroup (DPPTC) spin labels showing the principal magnetic axes $\left(x_{\mathrm{m}}, y_{\mathrm{m}}, z_{\mathrm{m}}\right)$. 


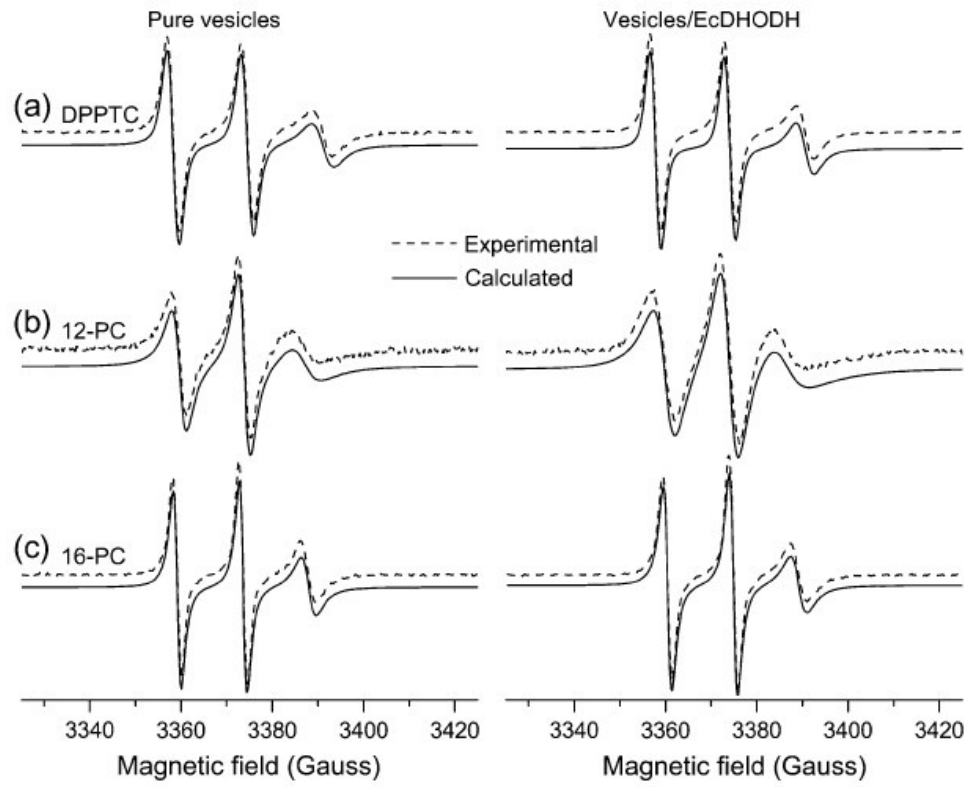

FIGURE 3 Experimental (dashed line) and simulated (solid line) ESR spectra from (a) DPPTC, (b) 12-, and (c) 16-PC labels in mixtures of DOPC/Triton X-100 (left column) and DOPC/Triton X-100/EcDHODH (right coluтn).

simulation purposes, in two categories. One comprises the one-component spectra of DPPTC, 5-, 10-, 12-, and 16-PC in pure vesicles (without EcDHODH) and of DPPTC, 12-, and 16-PC in EcDHODH-containing samples, which were then treated first. Seed values for the magnetic parameters $\left(A_{\mathrm{xx}}\right.$, $\left.A_{\mathrm{yy}}, A_{\mathrm{zz}}, g_{\mathrm{xx}}, g_{\mathrm{yy}}, g_{\mathrm{zz}}\right)$ were obtained from Ge et al (1990) (43). During the simulations process, the magnetic parameters were initially kept fixed, and the rotational diffusion tensor component $R_{\perp}$ was varied. After that, variations in the hyperfine and g-tensor components were carried out separately to avoid high correlation values between those parameters that can come up when they are varied together. Once a reasonable fit was obtained for the mixtures containing only vesicles of DOPC/Triton X-100, the calculated parameters thus obtained were used as starting values for the fits of EcDHODH-containing samples. The best-fit values calculated for the one-component ESR spectra are presented in Table 1 and the best spectral fits are shown in Figs. 3, $4 \mathrm{~A}$, and $5 \mathrm{~A}$ along with the respective experimental data.

As for 5-PC two-component spectral simulation, we used separate sets of parameters for each component. For the bulk component, the parameters determined previously for the one-component spectra (Table 1) were used to calculate the spectrum of what we denoted as component 1 in Table 1. These values were kept fixed and only the parameters for the boundary probes (component 2 in Table 1) were allowed to vary. The best-fit parameters thus obtained are shown in Table 1 and the calculated spectra in Fig. $4 B$, where it is also shown the individual components calculated by the NLSL program. As pointed out above, component 2 gives rise to parameters attributable to a probe molecule experiencing a fast-motion regime.

TABLE 1 Best-fit parameters from NLSL simulations of the ESR spectra obtained from spin labels (headgroup DPPTC and n-PC) incorporated into mixtures of DOPC/Triton X-100 and DOPC/Triton X-100/EcDHODH

\begin{tabular}{|c|c|c|c|c|c|c|c|c|c|}
\hline Sample & Component & $g_{x x}$ & $\mathrm{~g}_{\mathrm{yy}}$ & $\mathrm{g}_{z z}$ & $\mathrm{~A}_{\mathrm{xx}}$ & $\mathrm{A}_{\mathrm{yy}}$ & $\mathrm{A}_{\mathrm{zz}}$ & $\mathrm{A}_{0}$ & $\mathrm{R}_{\perp}\left(\times 10^{8} \mathrm{~s}^{-1}\right)$ \\
\hline \multicolumn{10}{|c|}{ No EcDHODH } \\
\hline DPPTC & 1 & 2.0078 & 2.0046 & 2.0022 & 6.0 & 5.9 & 37.5 & 16.5 & 0.58 \\
\hline 5-PC & 1 & 2.0075 & 2.0049 & 2.0020 & 7.4 & 6.5 & 30.2 & 14.7 & 0.22 \\
\hline $10-\mathrm{PC}$ & 1 & 2.0084 & 2.0063 & 2.0033 & 6.5 & 6.0 & 31.4 & 14.6 & 0.36 \\
\hline $12-\mathrm{PC}$ & 1 & 2.0089 & 2.0063 & 2.0033 & 5.3 & 4.9 & 33.2 & 14.5 & 0.79 \\
\hline 16-PC & 1 & 2.0102 & 2.0063 & 2.0033 & 5.3 & 4.9 & 33.2 & 14.5 & 1.94 \\
\hline \multicolumn{10}{|l|}{ EcDHODH } \\
\hline DPPTC & 1 & 2.0078 & 2.0047 & 2.0022 & 6.0 & 4.9 & 37.8 & 16.2 & 0.78 \\
\hline \multirow[t]{2}{*}{$5-\mathrm{PC}$} & 1 & 2.0075 & 2.0049 & 2.0020 & 7.4 & 6.5 & 30.2 & 14.7 & 0.22 \\
\hline & 2 & 2.0068 & 2.0047 & 2.0015 & 6.5 & 5.2 & 36.3 & 16.0 & 1.47 \\
\hline $12-\mathrm{PC}$ & 1 & 2.0090 & 2.0063 & 2.0033 & 5.3 & 4.9 & 33.3 & 14.5 & 0.66 \\
\hline $16-\mathrm{PC}$ & 1 & 2.0102 & 2.0063 & 2.0033 & 5.3 & 4.9 & 33.3 & 14.5 & 1.69 \\
\hline
\end{tabular}

$A$-tensor components are in Gauss. $A_{0}=\left(A_{\mathrm{xx}}+A_{\mathrm{yy}}+A_{\mathrm{zz}}\right) / 3$. Estimated errors: $\mathrm{R}_{\perp}(5 \%), A_{\mathrm{xx}}$ and $A_{\mathrm{yy}}(10 \%), A_{\mathrm{zz}}(5 \%)$. 


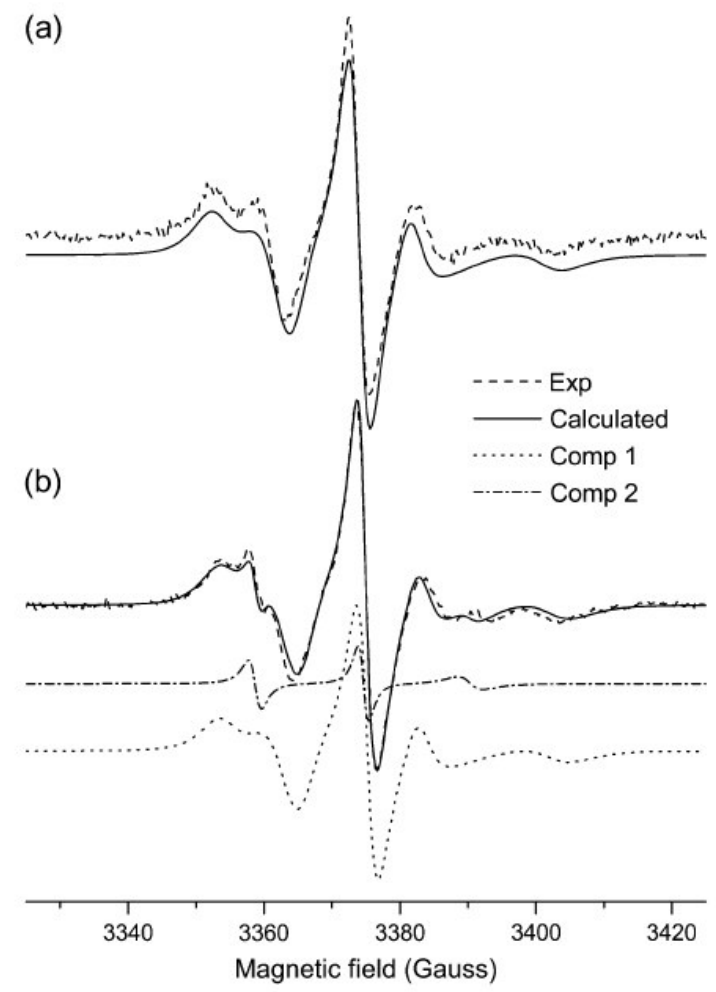

FIGURE 4 Experimental (dashed line) and calculated (solid line) ESR spectra from 5-PC spin probe in mixtures of $(a)$ DOPC/Triton X-100 and $(b)$ DOPC/Triton X-100/EcDHODH. $b$ shows the individual components: 1 (bulk lipid, dotted line) and 2 (boundary lipid, dash-dotted line) obtained by means of NLSL simulations.

The spectrum of the spin probe 10-PC in mixtures containing the enzyme was treated differently than the 5-PC spectrum described above. The NLSL program could not satisfactorily handle such a weak contribution to the overall spectrum because, in this case, the extra component is seen as a minor bump in the low-field resonance (Fig. 5 B). Even using two sets of parameters for the simulations, one of them was repeatedly set as a null contribution to the overall spectrum. A careful analysis of the individual spectrum determined for component 2 of the 5-PC probe in EcDHODHcontaining model membranes (Fig. $4 \mathrm{~B}$ ) suggested that the general features of the sharp-line spectrum in the 10-PC case were not dramatically different from those observed for component 2 of the 5 -PC probe. To verify whether this was a reasonable assumption, we manually added the experimental spectrum of 10-PC in pure vesicles (Fig. $5 \mathrm{~A}$ ) with the calculated spectrum for 5-PC boundary probe (component 2 in Table 1 and sharp-line spectrum in Fig. $4 B$ ). The intensities of these individual spectra were adjusted to achieve the best reproduction of the two-component experimental spectrum of 10-PC in EcDHODH/DOPC/Triton X-100. A very good agreement between the final sum spectrum and the experi-

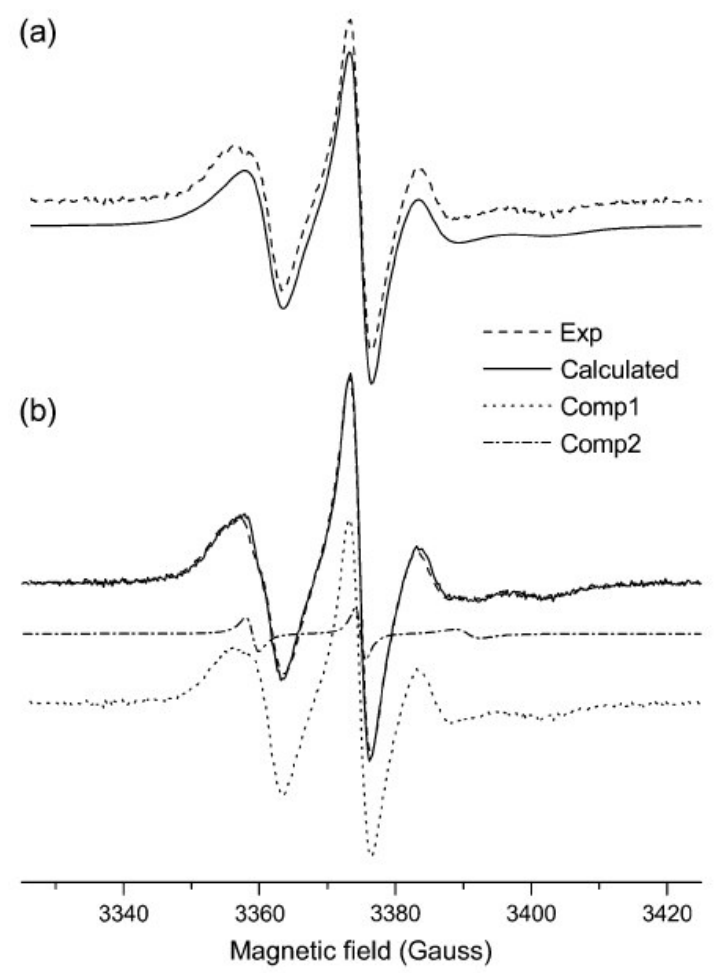

FIGURE 5 Experimental (dashed line) and calculated (solid line) ESR spectra from 10-PC spin probe in mixtures of (a) DOPC/Triton X-100 and (b) DOPC/Triton X-100/EcDHODH. $b$ shows the individual components: 1 (bulk lipid, dotted line) and 2 (boundary lipid, dash-dotted line) obtained as described in the text.

mental 10-PC spectrum from EcDHODH-containing vesicles was obtained as can be seen in Fig. 5 B. This indicates that 5 and 10-PC probe molecules in contact with EcDHODH experience similar microenvironments.

\section{Binding mechanism and enzyme catalysis}

The isotropic hyperfine parameter $A_{0}\left(A_{0}=A_{\mathrm{xx}}+A_{\mathrm{yy}}+A_{\mathrm{zz}}\right)$ is a well-known measure of the relative polarity around the nitroxide moiety $(18,30,44)$. The higher the $A_{0}$ value, the more polar is that environment. Hence, from Table 1, we can see that the headgroup spin label DPPTC is, as expected, in a much more hydrophilic environment than the chain labels showing $A_{0}$ value ( $16.5 \mathrm{G}$ ) comparable to the values observed for spin labels free in aqueous solution (ca. $16.9 \mathrm{G}$ ). From the headgroup region toward the vesicle interior, the $A_{0}$ values drop down to $14.5 \mathrm{G}$ for the 16 -PC probe (Table 1). In the hydrophobic part of the model membrane, $A_{0}$ parameter does not change significantly, thus suggesting that the polarity inside the vesicle does not show abrupt alterations. The same pattern for $A_{0}$ is also obtained for the bulk labels in samples containing the enzyme (component 1 in Table 1), which 
indicates that EcDHODH does not modify the solvent (or other polar molecules) accessibility to the hydrophobic carbon chains of the vesicles.

On the other hand, a considerable increase in polarity (from $14.7 \mathrm{G}$ to $16.0 \mathrm{G}$ ) is observed for the component 2 in the 5- and 10-PC spectra (Table 1) in the presence of EcDHODH. This result can be rationalized in terms of the residue composition of the EcDHODH N-terminal domain. The hydrophobic pattern for the residues in the two $\alpha$-helices and one $3_{10}$ helix that constitute the $\mathrm{N}$-terminal domain determined by ProtScale software (45) (Fig. 6) allows us to infer that such a region shows an amphipathic character with alternating hydrophobic and hydrophilic regions. The existence of a significant number of polar residues could account for the increase in polarity observed for the component 2 of 5-PC label in the presence of the enzyme. Norager et al. (11) suggested that this residue distribution in the N-terminal domain would make it possible for the enzyme to adhere to the membrane, but not as an integral membrane protein. Our ESR data supports this peripheral docking of EcDHODH to membranes because major changes are observed no further down the acyl chain than position $n=10$. However, we should bear in mind that, because of the low-ordered structure of the model membrane core, the protein penetration depth cannot be rigorously determined by our experiments. Nevertheless we can conclude that the modifications induced by the presence of the enzyme do take place in a somehow localized manner. Furthermore, the use of class $1 \mathrm{TcDHODH}$ in similar ESR experiments resulted in no spectral changes, thus suggesting that it is the $\mathrm{N}$-terminal extension the domain responsible for protein/membrane interaction.

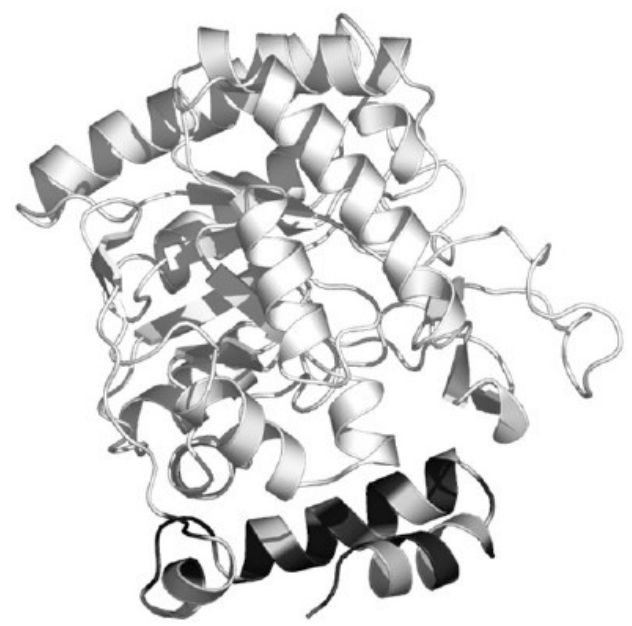

FIGURE 6 Ribbon representation of EcDHODH structure emphasizing the hydrophobicity pattern for $\mathrm{N}$-terminal domain (comprising residues in the two $\alpha$-helices and one $3_{10}$ helix) as determined by ProtScale software. The dehydrogenase-active domain is shown in cyan. Hydrophobic and hydrophilic residues in the $\mathrm{N}$-terminal domain are colored in dark and light gray, respectively.
The dynamics of the several spin probes can be discussed in terms of $R_{\perp}$ and $R_{/ /}$parameters. As observed previously in other articles that made use of the NLSL program, we also found that our simulations were insensitive to $R_{/ /}$. Hence, this value was kept fixed at $R_{/ /}=10 R_{\perp}$ during all simulations $(27,46,47)$. In the absence of EcDHODH, $R_{\perp}$ values of the chain labels followed an increasing gradient when one goes down along the acyl chain of the spin probe molecule (Table 1), which is compatible with the low-ordered and highly flexible organization of molecules inside mixed vesicles of phospholipid/detergent. The headgroup label DPPTC presents faster motion due to its exposition to the solvent, resulting in a less immobilized regime of motion.

In the presence of EcDHODH, we observed a greater $R_{\perp}$ value for the DPPTC probe and a decrease in $R_{\perp}$ values for the bulk labels (component 1 in Table 1) positioned in the hydrophobic part of the membrane as compared to the vesicles without the protein (Table 1). The enzyme induces lower fluidity of the carbon chains, while increasing the mobility of the headgroup probe probably due to the breakage of hydrogen bonds that would otherwise be formed by the headgroup. As for component 2 of the 5-PC ESR spectrum (Table 1), its $R_{\perp}$ value $\left(1.47 \times 10^{8} \mathrm{~s}^{-1}\right)$ increases significantly when compared to the $R_{\perp}$ parameter $\left(0.22 \times 10^{8} \mathrm{~s}^{-1}\right)$ obtained for the same 5-PC localized in the vesicle bulk (component 1 ), reaching rotational diffusion rates close to the ones observed for 16-PC labels.

Our results allow us to conclude that the presence of EcDHODH leads to a spacer effect between $n=5$ and $n=10$ carbon atoms of the DOPC vesicles. The determination of the size of this region is not accurate because a system composed of mixed vesicles does not present an ordering of the carbon chains as high as phospholipid bilayers. Nonetheless, this is strong evidence that a peripheral docking of the protein is taking place. The high $A_{0}$ and $R_{\perp}$ values $(16.0 \mathrm{G}$ and $1.47 \times$ $10^{8} \mathrm{~s}^{-1}$, respectively) for component 2 of the 5- and 10-PC probes indicate that a defect-like structure is formed by the adhesion of the EcDHODH N-terminal domain to the vesicle. The formation of defects in bilayers has been detected previously by ESR $(48,49)$. Kleinschmidt et al. reported the existence of a sharp component in the ESR spectrum from a spin-labeled stearic acid incorporated in DTPG bilayers after addition of melittin (48). Ge et al. showed that binding of ADP ribosylation factor 6 (ARF6), an activator of phospholipase D, to phosphatidy linositol 4,5-bisphosphate $\left(\mathrm{PIP}_{2}\right)$ containing vesicles creates defects in the bilayer structure at the headgroup and/or near the $\mathrm{n}=8-10$ position of the carbon acyl chain (26). Moreover, Ge et al. (49) concluded that the sharp component can be significantly enhanced or reduced through specific lipid/lipid or lipid/protein interactions.

The formation of such defect may play a fundamental role in the catalytic cycle of the enzyme because the $\mathrm{N}$-terminal region is also responsible for regulating the access to the protein active site. The crystal structure of HsDHODH in the presence of several inhibitors showed that the N-terminal 
contains the site for quinone binding (10). The N-terminal domain, along with the active site loop, acts as a cleft, shielding the FMN cofactor and orotate from the solvent (11) When bound to the membrane, the N-terminal induces the appearance of the defect (spacer effect) so that quinones dispersed in the membrane, which act as electron acceptors in the second half of the redox reaction catalyzed by EcDHODH, can now bind to the protein. The appearance of such defect is thus crucial for enzyme catalysis to take place.

The authors thank the Brazilian agencies Fundação de Amparo à Pesquisa do Estado de São Paulo (FAPESP) and Conselho Nacional de Desenvolvimento Científico e Tecnológico (CNPq) for financially supporting this work. M.C.N. thanks a Young Scientist Fellowship from FAPESP (Grant No. 01/ 14583-0). A.J.C.F. thanks CNPq for a Research Fellowship (307102/2006-8). This work is part of a joint program Programa Núcleo de Excelência (PRONEX)/FAPESP/CNPq (Grant No. 03/09859-2). The authors are also grateful to Prof. K. Jensen who kindly provided the PAG1 plasmid and E. coli cell strains S06645 and S06740 used for EcDHODH expression.

\section{REFERENCES}

1. Jones, M. E. 1980. Pyrimidine nucleotide biosynthesis in animals: Genes, enzymes, and regulation of UMP biosynthesis. Annu. Rev Biochem. 49:253-279.

2. Bjomberg, O., P. Rowland, S. Larsen, and K. F. Jensen. 1997. Active site of dihydroorotate dehydrogenase A from Lactococcus lactis investigated by chemical modification and mutagenesis. Biochemistry. 36:16197-16205.

3. Rowland, P., F. S. Nielsen, K. F. Jensen, and S. Larse. 1997. The crystal structure of the flavin containing enzyme dihydroorotate dehydrogenase A from Lactococcus lactis. Structure. 5:239-252.

4. Dimitrijevic, M., and R. R. Bartlett. 1996. Leflunomide, a novel immunomodulating drug, inhibits homotypic adhesion of peripheral blood and synovial fluid mononuclear cells in rheumatoid arthritis Inflamm. Res. 45:550-556.

5. Smolen, J. S., J. R. Kalden, D. L. Scott, B. Rozman, T. K. Kvien, A. Larsen, I. Loew-Friedrich, C. Oed, and R. Rosenburg. 1999. Efficacy and safety of leflunomide compared with placebo and sulphasalazine in active rheumatoid arthritis: a double-blind, randomised, multicentre trial. Lancet. 353:259-266.

6. Ruckemann, K., L. D. Fairbanks, E. A. Carrey, C. M. Hawrylowicz, D. F. Richards, B. Kirschbaum, and H. A. Simmonds. 1998. Leflunomide inhibits pyrimidine de novo synthesis in mitogen-stimulated T-lymphocytes from healthy humans. J. Biol. Chem. 273:21682-21691.

7. Davis, J. P., G. A. Cain, W. J. Pitts, R. L. Magolda, and R. A. Copeland. 1996. The immunosuppressive metabolite of leflunomide is a potent inhibitor of human dihydroorotate dehydrogenase. Biochemistry. 35:1270-1273.

8. Loffler, M., K. Grein, W. Knecht, A. Klein, and U. Bergjohann. 1998. Dihydroorotate dehydrogenase - Profile of a novel target for antiproliferative and immunosuppressive drugs. Adv. Exp. Med. Biol. 431: 507-513.

9. Knecht, W., J. Henseling, and M. Loffler. 2000. Kinetics of inhibition of human and rat dihydroorotate dehydrogenase by atovaquone, lawsone derivatives, brequinar sodium and polyporic acid. Chem. Biol. Interact. 124:61-76.

10. Liu, S. P., E. A. Neidhardt, T. H. Grossman, T. Ocain, and J. Clardy. 2000. Structures of human dihydroorotate dehydrogenase in complex with antiproliferative agents. Structure. 8:25-33.

11. Norager, S., K. F. Jensen, O. Bjömberg, and S. Larsen. 2002. E. coli dihydroorotate dehydrogenase reveals structural and functional distinctions between different classes of dihydroorotate dehydrogenase. Structure. 10:1211-1223.
12. Hansen, M., J. Le Nours, E. Johansson, T. Antal, A. Ullrich, M. Loffler, and S. Larsen. 2004. Inhibitor binding in a class 2 dihydroorotate dehydrogenase causes variations in the membrane-associated $\mathrm{N}$-terminal domain. Protein Sci. 13:1031-1042.

13. Hurt, D. E., J. Widom, and J. Clardy. 2006. Structure of Plasmodium falciparum dihydroorotate dehydrogenase with a bound inhibitor. Acta Crystallogr. D. Biol. Crystallogr. 62:312-323.

14. Rowland, P., O. Bjomberg, F. S. Nielsen, K. F. Jensen, and S. Larsen. 1998. The crystal structure of Lactococcus lactis dihydroorotate dehydrogenase A complexed with the enzyme reaction product throws light on its enzymatic function. Protein Sci. 7:1269-1279.

15. Rowland, P., S. Norager, K. F. Jensen, and S. Larsen. 2000. Structure of dihydroorotate dehydrogenase B: electron transfer between two flavin groups bridged by an iron-sulphur cluster. Struct. Fold. Des. 8: 1227-1238.

16. Karibian, D. 1978. Dihydroorotate dehydrogenase (Escherichia coli). Methods Enzymol. 51:58-63.

17. Knecht, W., R. Kohler, M. Minet, and M. Loffler. 1996. Anti-peptide immunoglobulins from rabbit and chicken eggs recognise recombinant human dihydroorotate dehydrogenase and a $44-\mathrm{kDa}$ protein from rat liver mitochondria. Eur. J. Biochem. 236:609-613.

18. Hubbell, W. L., and H. M. McConnell. 1971. Molecular motion in spin-labeled phospholipids and membranes. J. Am. Chem. Soc. 93:314326.

19. Berliner, L. J., editor. 1979. Spin Labeling Theory and Applications II. Academic Press, New York.

20. Hubbell, W. L., H. S. Mchaourab, C. Altenbach, and M. A. Lietzow. 1996. Watching proteins move using site-directed spin labeling. Structure. 4:779-783.

21. Borbat, P. P., A. J. Costa-Filho, K. A. Earle, J. K. Moscicki, and J. H. Freed. 2001. Electron spin resonance in studies of membranes and proteins. Science. 291:266-269.

22. Dong, J. H., G. Y. Yang, and H. S. Mchaourab. 2005. Structural basis of energy transduction in the transport cycle of Msb. Science. 308: 1023-1028.

23. Park, S. Y., P. P. Borbat, G. Gonzalez-Bonet, J. Bhatnagar, A. M. Pollard, J. H. Freed, A. M. Bilwes, and B. R. Crane. 2006. Reconstruction of the chemotaxis receptor-kinase assembly. Nat. Struct. Mol. Biol. 13:400-407.

24. Eps, N. V., W. M. Oldham, H. E. Hamm, and W. L. Hubbell. 2006. Structural and dynamical changes in an $\alpha$-subunit of a heterotrimeric G protein along the activation pathway. Proc. Natl. Acad. Sci. USA. 103:16194-16199.

25. Marsh, D., and L. I. Horväth. 1998. Structure, dynamics and composition of the lipid-protein interface. Perspectives from spin-labelling. Biochim. Biophys. Acta. 1376:267-296.

26. Ge, M., J. S. Cohen, H. A. Brown, and J. H. Freed. 2001. ADP ribosylation factor 6 binding to phosphatidylinositol 4,5-bisphosphatecontaining vesicles creates defects in the bilayer structure: an electron spin resonance study. Biophys. J. 81:994-1005.

27. Citadini, A. P. S., A. P. A. Pinto, A. P. U. Araújo, O. R. Nascimento, and A. J. Costa-Filho. 2005. EPR studies of chlorocatechol 1, 2-dioxygenase: evidences of iron reduction during catalysis and of the binding of amphipatic molecules. Biophys. J. 88:3502-3508.

28. Cuello, L. G., D. M. Cortes, and E. Perozo. 2004. Molecular architecture of the KvAP voltage-dependent $\mathrm{K}^{+}$channel in a lipid bilayer. Science. 306:491-495.

29. Ge, M. T., K. A. Field, R. Aneja, D. Holowka, B. Baird, and J. H. Freed. 1999. Electron spin resonance characterization of liquid ordered phase of detergent-resistant membranes from RBL-2H3 cells. Biophys. J. 77:925-933.

30. Marsh, D. 2001. Polarity and permeation profiles in lipid membranes. Proc. Natl. Acad. Sci. USA. 98:7777-7782.

31. Costa-Filho, A. J., Y. Shimoyama, and J. H. Freed. 2003. A 2DELDOR study of the liquid ordered phase in multilamellar vesicle membranes. Biophys. J. 84:2619-2633. 
32. Collado, M. I., F. M. Goni, A. Alonso, and D. Marsh. 2005. Domain formation in sphingomyelin/cholesterol mixed membranes studied by spin-label electron spin resonance spectroscopy. Biochemistry. 44: 4911-4918.

33. Bjomberg, O., A. C. Gruner, P. Roepstorff, and K. F. Jensen. 1999. The activity of Escherichia coli dihydroorotate dehydrogenase is dependent on a conserved loop identified by sequence homology, mutagenesis, and limited proteolysis. Biochemistry. 38:2899-2908.

34. López, O., A. Maza, L. Coderch, C. López-Iglesia, E. Wherli, and J. L. Parra. 1998. Direct formation of mixed micelles in the solubilization of phospholipid liposomes by Triton X-100. FEBS Lett. 426: 314-318.

35. Kragh-Hansen, U., M. Maire, and J. V. Moller. 1998. The mechanism of detergent solubilization of liposomes and protein-containing membranes. Biophys. J. 75:2932-2946.

36. Jost, P. C., O. H. Griffith, R. A. Capaldi, and G. A. Vanderkooi. 1973. Evidence for boundary lipid in membranes. Proc. Natl. Acad. Sci. USA 70:480-484.

37. Kang, S. Y., H. S. Gutowsky, J. C. Hsung, R. Jacobs, T. E. King, D. Rice, and E. Oldfield. 1979. Nuclear magnetic resonance investigations of the cytochrome oxidase-phospholipid interaction: a new model for boundary lipid. Biochemistry. 18:3257-3267.

38. Marsh, D., and A. Watts. 1982. Spin labeling and lipid-protein interactions in membranes. In Lipid-Protein Interactions. P. C. Jost and O. H. Griffith, editors. John Wiley \& Sons, New York. 53.

39. Takashima, E., D. K. Inaoka, A. Osanai, T. Nara, M. Odaka, T. Aoki, K. Inaka, S. Harada, and K. Kita. 2002. Characterization of the dihydroorotate dehydrogenase as a soluble fumarete reductase in Trypanosoma cruzi. Mol. Biochem. Parasitol. 122:189-200.

40. Meirovitch, E., A. Nayeem, and J. H. Freed. 1984. An analysis of protein-lipid interactions based on model simulations of ESR spectra. J. Phys. Chem. 88:3454-3465.
41. Schneider, D. J., and J. H. Freed. 1989. Calculating slow motional magnetic resonance spectra: a user's guide. In Biological Magnetic Resonance. L. J. Berliner and J. Reuben, editors. Plenum Publishing, New York. 8:1-76.

42. Budil, D. E., S. Lee, S. Saxena, and J. H. Freed. 1996. Nonlinear-least squares analysis of slow-motion EPR spectra in one and two dimensions using a modified Levenberg-Marquardt algorithm. J. Magn. Reson. A. 120:155-189.

43. Ge, M., S. B. Rananavare, and J. H. Freed. 1990. ESR studies of stearic-acid binding to bovine serum-albumin. Biochim. Biophys. Acta. 1036:228-236.

44. Griffith, O. H., and P. A. Jost. 1976. Lipid spin labels in biological membranes. In Spin Labeling: Theory and Applications. L. J. Berliner, editor. Academic Press, New York. 453-523.

45. Gasteiger, E., C. Hoogland, A. Gattiker, S. Duvaud, M. R. Wilkins, R. D. Appel, and A. Bairoch. 2005. Protein identification an analysis tools on the ExPASy server. In The Proteomics Protocols Handbook. J. M. Walker, editor. Humana Press, Totowa, NJ. 571-607.

46. Kar, L., E. Ney-Igner, and J. H. Freed. 1985. Electron spin resonance and electron-spin-echo study of oriented multilayers of $L \alpha$ dipalmitoylphosphatidy lcholine water system. Biophys. J. 48:569-595.

47. Ge, M., and J. H. Freed. 1999. Electron-spin resonance study of aggregation of Gramicidin in dipalmitoylphosphatidylcholine bilayers and hydrophobic mismatch. Biophys. J. 76:264-280.

48. Kleinschmidt, J. H., J. E. Mahaney, D. D. Thomas, and D. Marsh. 1997. Interaction of bee venom melittin with zwitterionic and negatively charged phospholipid bilayers: a spin-label electron spin resonance study. Biophys. J. 72:767-778.

49. Ge, M. T., A. Gidwani, H. A. Brown, D. Holowka, B. Baird, and J. H. Freed. 2003. Ordered and disordered phases coexist in plasma membrane vesicles of RBL-2H3 mast cells. An ESR study. Biophys. $J$. 85:1278-1288. 